\title{
BIOÉTICA E ATENÇÃO BÁSICA: UM ESTUDO DE ÉTICA DESCRITIVA COM ENFERMEIROS E MÉDICOS DO PROGRAMA SAÚDE DA FAMÍLIA
}

\section{ELMA LOURDES CAMPOS PAVONE ZOBOLI}

Tese de Doutorado apresentada ao Departamento de Prática em Saúde Pública da Faculdade de Saúde Pública da Universidade de São Paulo para obtenção do Grau de Doutor

Área de Concentração: Serviços de Saúde

ORIENTADOR: PROF. DR. PAULO ANTONIO DE CARVALHO FORTES 
Autorizo, exclusivamente para fins acadêmicos e científicos, a reprodução total ou parcial desta dissertação, por processos fotocopiadores.

Assinatura:

Data:

$$
44335 / 2003 d x
$$




\section{AGRADECIMENTOS}

Vida...Dádivas...Dons...Gratidão. Quando, em nossa vida, recebemos dons que ultrapassam o mérito, que não são simples decorrências de merecimento, mas presentes, dádivas de amizade e generosidade, portanto imerecidos, movemo-nos a um profundo agradecimento:

Ao Professor Paulo Antonio de Carvalho Fortes pela dedicação, atenção e respeito na orientação desta tese e pelas oportunidades de trabalho conjunto que me tem propiciado na vida acadêmica. Ao amigo Paulo por permitir que compartilhássemos alegrias e tristezas que permearam nossas vidas durante esta jornada.

Aos Professores José Eduardo de Siqueira, Marcio Fabri dos Anjos, Maria Rita Bertolozzi e Volnei Garrafa por tomarem com alegria e empenho a tarefa de participarem das bancas de qualificação e defesa, enriquecendo este trabalho com suas valiosas e precisas contribuições.

Aos serviços de saúde que, apesar da delicadeza que cerca o tema, objeto desta tese, abriram suas portas, desnudando segredos de seu cotidiano.

Aos enfermeiros e médicos, sujeitos anônimos desta pesquisa, pela disponibilidade e confiança com que concederam as entrevistas em meio a seus múltiplos afazeres na unidade básica de saúde.

À Rosimeire Angela Queiroz Soares e Sandra Cristina Ferreira Sepúlveda, alunas do curso de graduação da Escola de Enfermagem da Universidade de São Paulo (EEUSP), pela cuidadosa transcrição das entrevistas. 
Às colegas docentes do Departamento de Enfermagem de Saúde Coletiva da EEEUSP pelo apoio expresso não só nas palavras de incentivo, mas por me concederem tempo para o desenvolvimento deste trabalho, ao assumirem o ônus do necessário afastamento de minhas ocupações na lide diária.

Às docentes da EEUSP que me encorajaram com palavras de ânimo e, especialmente, à Profa. Maria Cristina Komatsu Braga Massarollo por partilhar comigo seus conhecimentos e experiência no ensino da bioética e ética em enfermagem.

Aos funcionários do Departamento de Enfermagem em Saúde Coletiva da EEUSP pela sua solicitude e presteza.

À Professora Maria Cristina Schlucat Cassim pelo carinho, prontidão e entusiasmo na revisão dos originais do relatório final.

Apesar de marcar nossa vida indelevelmente, uma tese de doutorado não constitui acontecimento pontual, outrossim, resulta e nutre-se de distintas experiências, também permeadas de benesses que, como tal, são imerecidas e requerem nosso grato reconhecimento:

Ao Professores Leo Pessini e Christian de Paul de Barchifontaine por terem me apresentado à Bioética, amparado-me em meus primeiros passos neste campo e seguirem me presenteando com seu apoio amigo.

À Professora Marcia Furquim de Almeida pela amizade demonstrada não apenas no respeito as minhas opções, mas também no carinho com que tem acompanhado minha vida acadêmica.

Aos amigos e companheiros da Sociedade Brasileira de Bioética e do Núcleo São Paulo pelas manifestações de estímulo. 
Aos amigos e companheiros da Prefeitura Municipal de Santo André e do Centro Universitário São Camilo que, apesar da distância nos separar, sempre tiveram palavras de encorajamento nos eventuais reencontros que a vida nos proporcionou.

Tarefa árdua a de agradecer. Não tanto pelas peculiaridades inerentes ao exercício de um dos mais justos sentimentos morais, a gratidão, mas pelo temor do esquecimento. Inúmeros são os presentes recebidos e os limites impostos pelo papel e pela memória podem nos trair no momento do agradecimento. Neste caso, restanos apelar para a mesma amizade que permitiu as dádivas e contar, antecipadamente, com mais algumas: a compreensão e o perdão dos não mencionados. 
Para Rodolfo, com amor, pois sem sua compreensão, paciência, estímulo, apoio, companheirismo e cumplicidade este trabalho não seria possível e tampouco teria sentido. 


\section{RESUMO}

Zoboli ELCP. Bioética e atenção básica: um estudo de ética descritiva com enfermeiros e médicos do Programa Saúde da Família. São Paulo; 2003. [Tese de Doutorado - Faculdade de Saúde Pública da Universidade de São Paulo].

Estudo empírico, qualitativo, de ética descritiva, no qual foram entrevistados 18 enfermeiros e 17 médicos do Programa Saúde da Família, no Município de São Paulo, SP, com os objetivos de identificar e comparar os problemas éticos vivenciados $\mathrm{e}$ os fundamentos que balizam o equacionamento para a tomada de decisão frente a problemas éticos. Num primeiro momento da entrevista, solicitou-se aos profissionais que listassem problemas éticos vivenciados a partir da narrativa de um caso, em seguida pedia-se que recomendassem uma solução para situações hipotéticas, justificando a indicação. Os resultados apontam que os problemas éticos na atenção básica são, em geral, preocupações do cotidiano da atenção à saúde, parecendo triviais frente às situações críticas, dramáticas, típicas do hospital, que requerem soluções imediatas e são mais freqüentes na literatura. A sutileza que os cerca pode fazer com que passem desapercebidos, com conseqüências desastrosas para a assistência prestada aos usuários, famílias e comunidade adscrita. Os enfermeiros e médicos, de maneira geral, preocupam-se em preservar os direitos individuais dos usuários, mas o fazem de forma a proteger as relações vinculares, numa mescla dos enfoques principialista e do cuidado. A atenção básica, quando comparada com a hospitalar, lida com fatos e valores distintos e, por vezes, de maior amplitude e complexidade, ainda que de menor dramaticidade, demandando-se mais investigações que possibilitem aprofundar esta interface da bioética e da atenção básica.

Descritores: Bioética. Temas bioéticos. Saúde Pública, ética. Cuidados Primários de Saúde, ética. Programa Saúde da Família. 


\section{SUMMARY}

Zoboli ELCP. Bioética e atenção básica: um estudo de ética descritiva com enfermeiros e médicos do Programa Saúde da Família. [Bioethics and primary healthcare: a descriptive ethics study with nurses and doctors from the Family Health Program]. São Paulo (BR); 2003. [Tese de Doutorado - Faculdade de Saúde Pública da Universidade de São Paulo].

This is an empirical, qualitative, descriptive ethics study. The objectives were to identify and compare ethical problems experienced and approaches used by primary health care professionals in ethical decision making. The research subjects were eighteen nurses and seventeen physicians of the Family Health Program in the city of Sao Paulo, SP, Brazil. In the first half of a semi-structured interview they were asked to relate a case from their experience that they considered an ethical problem. In the second half they were asked to recommend a solution to hypothetical situations and then to justify their choices. The cases related by the respondents indicate that the ethical problems in primary healthcare are not the critical, dramatic and rare cases found in hospitals which require immediate decisions. These ethical problems might seem trivial when compared with those currently discussed in the literature on medical ethics. The subtlety of the ethical problems in primary healthcare might make them difficult to discern and may lead to disastrous consequences for patients, families and communities. Nurses and physicians, in general, are concerned about preserving the rights of the individuals, but they do this in such a way that they protect the relationships, in a mixture of principialism and ethics of care approaches. In contrast to high-technology settings, primary healthcare deals with less dramatic, more complex issues and different values which might complicate ethical decision making. Further research is required to deepen our understanding of the interface between bioethics and primary healthcare.

Descriptors: Bioethics. Bioethical issues. Public Health, ethics. Primary health care, ethics. Family Health Program. 


\section{ÍNDICE}

1 INTRODUÇÃO

2 OBJETIVOS 18

3 PROCEDIMENTOS METODOLÓGICOS 20

3.1 Tipo de Estudo 20

3.2 Sujeitos do Estudo $\quad 24$

3.2.1 Perfil dos Enfermeiros Entrevistados $\quad 26$

3.2.2 Perfil dos Médicos Entrevistados 28

3.3 Cenário do Estudo $\quad 30$

3.4 Coleta de Dados 33

3.5 Referencial Teórico 35

3.6 Organização dos Dados 36

4 REFERENCIAL TEÓRICO 44

4.1 O Enfoque Principialista: a Ênfase nos Princípios e nos Atos 46

4.1.1 Para Entender o Principialismo 46

4.1.2 Os Quatro Princípios da Ética Biomédica 53

4.2 O Enfoque das Virtudes: a Ênfase no Caráter dos Agentes 70

4.2.1 Natureza e Noção das Virtudes na Explicação de Alasdair MacIntyres $\quad 72$

4.3 O Enfoque do Cuidado: a Ênfase nas Relações $\quad 87$

4.3.1 O Reconhecimento de uma Voz Diferente 94

4.3.2 Conceitos de Eu e Moralidade $\quad 96$

4.4 O Enfoque da Casuística: a Ênfase nos Casos Clínicos 100

4.4.1 Casuística: Elementos e Conceituação 103

4.4.2 A Casuística na Ética Clínica 106

4.5 O Enfoque da Ética Profissional: a Ênfase nos Códigos Deontológicos $\quad 113$

5 RESULTADOS E DISCUSSÃO 118

5.1 Resultados e Discussão: Momento I 118

5.1.1 As Relações com os Usuários e as Famílias 133 
5.1.2 As Relações da Equipe

5.1.3 As Relações com a Organização e o sistema de saúde $\quad 178$

5.2 Resultados e Discussão: Momento II 186

6 CONSIDERAÇÕES FINAIS $\quad 228$

7 REFERÊNCIAS BIBLIOGRÁFICAS 233

ANEXOS

Anexo 1 - Termo de responsabilidade da pesquisadora A1

Anexo 2 - Solicitação de consentimento institucional para realização da pesquisa A2

Anexo 3 - Aprovação pelo Comitê de Ética em Pesquisa da FSP A3 


\section{INTRODUÇÃO}

A fim de viabilizar a convivência a sociedade e/ou os grupos têm traçado, ao longo da história da humanidade, diferentes balizamentos. A ética é um deles. A palavra ética, do grego éthos, refere-se aos costumes, à conduta de vida e às regras de comportamento. Circunscreve-se ao agir humano, aos comportamentos cotidianos e às opções existenciais. Etimologicamente, significa o mesmo que moral (do latim mos, moris), sendo usual o emprego destas palavras uma pela outra, quase como sinônimos.

Segundo Durant (1995), a moral ou a ética abrange como campos de ação:

- A pesquisa: entendida como a procura do que é certo, do que é necessário fazer. É a pesquisa de normas ou de regras de comportamento, a análise dos valores, a reflexão sobre os fundamentos dos direitos, dos valores e das normas. $O$ que importa neste campo de abrangência é buscar, conhecer e descobrir os valores para somente então interiorizá-los ou seguir as normas. Esta pesquisa não é exclusividade de especialistas, constitui responsabilidade de cada pessoa.

- A sistematização da reflexão: é o resultado da pesquisa, podendo-se entender a ética ou a moral como "um conjunto organizado, sistemático, hierarquizado de regras ou de valores". Neste sentido, são distintas as aplicações permitidas:

- O conjunto mais ou menos organizado e coerente de valores, de regras e de direções de vida de cada um: "minha moral pessoal";

- O sistema ou a síntese elaborada pelos diferentes pensadores: a ética de Aristóteles, de Kant, de Descartes etc.

- As exigências, os valores, os princípios que servem de base e justificativa para o comportamento de um grupo ou de uma sociedade: ética cristã, ética grega, moral católica, moral marxista etc. 
- A prática: a experiência concreta do cotidiano, quando ocorre a realização dos valores, o esforço pessoal para aplicar os princípios e observar as normas.

A este ponto, cabe considerar que é comum, mas não unânime, a distinção entre ética e moral, entendendo a primeira como o estudo dos fundamentos da segunda. Isto a limita aos dois primeiros campos de ação (o da pesquisa e sistematização), restando o da prática à moral (DURANT 1995).

Neste sentido, também não se pode esquecer que a vida cotidiana confere às palavras uma história específica que lhes agrega um sentido próprio. Assim, é pertinente ponderar que, no Ocidente, a primazia cultural do cristianismo confere à palavra moral uma conotação religiosa, referindo-se a um sistema de princípios imutáveis e aparentemente definidos. Desta forma, este termo reveste-se de um sentido fechado e conservador. Dentro deste contexto, o realce para a palavra ética, ocorre na intenção de destacar uma conotação de moral não religiosa, secular. Daí a preferência em usar ética à moral, mesmo reconhecendo-se a sinonímia dos termos por sua etimologia (DURANT 1995).

A ética da saúde ocupa lugar de destaque no conjunto das reflexões éticas, pois enfoca questões relacionadas à manutenção e à qualidade de vida das pessoas. Leopoldo e Silva (1998) considera a ética da saúde profundamente enraizada no terreno dos direitos humanos, pois a vida é o primeiro dos direitos. Segue o autor afirmando que a ética da saúde implica "compromisso com a realização histórica de valores que encarnem nas condições determinadas de situações sociais e politicas diferenciadas o direito de que todo ser humano deveria primordialmente usufruir" (p. $35)$.

$\mathrm{Na}$ busca de uma abordagem secular, interdisciplinar, prospectiva, global e sistemática para os temas de ética, consoante com a afirmação e a construção dos direitos humanos que marcam o mundo moderno nos anos 70 , tem se instaurado na área da saúde, nas últimas três décadas, a bioética. Antigas concepções verticais, 
autoritárias, com deveres e princípios absolutos, não são mais aceitas e passam a ser substituídas por alternativas de caráter horizontal e democrático, com responsabilidades reciprocas e bilaterais (GRACIA 1989; DURANT 1995).

O termo bioética, literalmente, significa ética da vida. O vocábulo de raiz grega bios designa o desenvolvimento observado nas ciências da vida, como a ecologia, a biologia e a medicina, dentre outras. Ethos busca trazer à consideração os valores implicados nos conflitos da vida (GRACIA 1998a; PESSINI e BARCHIFONTAINE 2000).

Este neologismo é cunhado pelo oncologista Van Ressenlaer Potter no livro "Bioethics: bridge to the future", publicado em 1971, com o objetivo de, ao juntar num só campo os conhecimentos da biologia e da ética, ajudar a humanidade em direção a uma participação racional, mas cautelosa, no processo da evolução biológica e cultural:

"The purpose of this book is to contribute to the future of the human species by promoting the formation of a new discipline, the discipline of Bioethics. If there are 'the cultures' that seem unable to speak to each other - science and the humanities - and if this is part of the reason that the future seems in doubt, then possibly, we might build a 'bridge to the future' by building the discipline of Bioethics as a bridge between the two cultures." (POTTER 1971, p. vii)

Desta forma, a definição de bioética abraça este processo de confronto entre os fatos biológicos e os valores humanos na tomada de decisões envolvendo os problemas práticos em diferentes áreas da vida, como na assistência médicosanitária: 


\begin{abstract}
“(...) cobra todo su sentido la definición de la bioética como el proceso de contrastación de los hechos biológicos con los valores humanos, a fin de globalizar los juicios sobre las situaciones y de esa forma mejorar la toma decisiones, incrementando su corrección y su calidad. Una área particular de la bioética sería la bioética sanitaria o bioética clínica, que en consecuencia se podria definir como la inclusión de los valores en la toma de decisiones sanitarias, a fin de aumentar su corrección y su calidad." (GRACIA 1998a, p. 30).
\end{abstract}

$\mathrm{Na}$ introdução à segunda edição da Enciclopédia de Bioética (REICH 1995a) encontra-se o termo bioética definido como:

\footnotetext{
"o estudo sistemático das dimensões morais, incluindo a visão, a decisão, a conduta e as normas, das ciências da vida e da saúde, utilizando uma variedade de metodologias éticas num contexto interdisciplinar."
}

Desta definição, é possível depreender que há diferentes tendências na configuração das formas de sistematizar e tratar a análise teórica em bioética. Entre os paradigmas mais comuns destacam-se o do liberalismo que tem nos direitos humanos a justificativa para o valor central da autonomia do indivíduo sobre seu próprio corpo e as decisões relativas à sua vida; o das virtudes que coloca a tônica na boa formação do caráter e da personalidade das pessoas ou dos profissionais; o da casuística que incentiva a análise de casos a fim de elaborar características paradigmáticas para analogias em situações semelhantes; o narrativo que entende a intimidade e a identidade experimentadas pelas pessoas ao contarem ou seguirem histórias como um instrumental facilitador da análise ética; o do cuidar que defende a importância das relações interpessoais e da solicitude e o principialista, baseado nos princípios da beneficência, não maleficência, autonomia e justiça (ANJOS 1997; PESSINI e BARCHIFONTAINE 2000). 
Este último modelo de análise, também conhecido como principialismo, talvez seja a tendência mais difundida. Sem conhecê-la, é quase impossível compreender a recente história da bioética, pois as demais teorias, em sua maioria, construíram-se a partir de um diálogo com esta, seja corroborando-a ou contradizendo-a. Tal a sua preponderância que, por vezes, é chamada de "mantra da bioética" (GRACIA 1998a).

O principialismo mostra-se atrativo para a prática da atenção médico-sanitária por propiciar uma linguagem simples, objetiva e que possibilita a verbalização de percepções e sentimentos éticos, permitindo uma abordagem sistematizada dos problemas práticos do cotidiano (PESSINI e BARCHIFONTAINE 1998; SCHRAMM 1998).

E, é exatamente este cotidiano ou ainda o que se tem entendido e delimitado como o cotidiano da saúde na visão da bioética, que lhe impõe, atualmente, um dos mais candentes desafios. Partindo-se das idéias de Giovanni Berlinguer (1993), podese dizer que o limite e a exceção parecem ter assumido o lugar da cotidianidade, pois "os casos de situações limites", como a eutanásia, o aborto, a reprodução medicamente assistida etc. têm sido a constante nas reflexões bioéticas, negligenciando-se os problemas de ordem ética que envolvem a maioria das pessoas em sua vida cotidiana:

"Discute-se, justamente, sobre alguns casos de eutanásia, de 'boa morte' eventual, mas ignoram-se milhões de cacotanásias, de péssimas mortes prematuras e não merecidas que acontecem por falta de prevenção e tratamento. Dedicam-se, justamente, energias científicas e reflexões morais à fecundação artificial, mas trabalha-se muito pouco, tanto na pesquisa como nas atividades práticas, sobre a comuníssima esterilidade, que só em raros casos pode ser resolvida com a fecundação artificial. 
Criam-se preocupações justas a respeito do controle farmacológico ou genético do comportamento, deixando de se considerar, como análise científica também, a atual constante manipulação humana, através de outros meios." (BERLINGUER 1993, p. 21 e 22).

Para compreender esta questão, faz-se necessário reexaminar alguns aspectos que cercam a origem e a evolução deste campo da ética.

Como mencionado previamente, o vocábulo bioética é cunhado por Potter, professor da Universidade de Wiscousin (EUA), em seu livro publicado em 1971. No entanto, antes disso, em 1962, lança a idéia do que viria a conformar seu entendimento de bioética. $\mathrm{Na}$ Universidade de Dakota do Sul, em palestra comemorativa dos 100 anos da inauguração do sistema land-grant, após 22 anos de pesquisa em oncologia, pensa que a ocasião chama para algo mais filosófico e decide falar de algo que tinha em mente e nunca havia expresso. Em uma apresentação intitulada "Ponte para o futuro, um conceito de progresso humano" questiona o progresso; para onde o avanço materialista da ciência e da tecnologia está levando a cultura ocidental; o tipo de futuro que está se construindo e se há opções. Em 1970, publica a palestra e em janeiro de 1971 o livro, que se tornam conhecidos do público em geral através de reportagem veiculada pela Revista Time, em 19 de abril de 1971. A partir daí, a palavra emplaca na mídia e a expressão bioética torna-se parte da linguagem diária. Seu significado original é perscrutado e redefinido, principalmente pelos especialistas em ética médica, sendo confundida, muitas vezes, com esta (POTTER 1998; PESSINI e BARCHIFONTAINE 2000).

Colabora para isto, provavelmente, o fato de André Hellengers, obstetra holandês, fisiologista e demógrafo da Universidade de Georgetown, ter usado o termo em um contexto institucional para designar uma área de pesquisa ou campo de aprendizagem ao fundar, também em 1971, The Joseph and Rose Kennedy Institute for the Study of Human Reproduction and Bioethics. Este pesquisador, a partir do seu trabalho no Instituto, é um dos que imprime à bioética seu significado corrente, ao 
aplicá-la à ética da medicina e das ciências biomédicas. Assim, nos anos setenta, a atenção volta-se mais para as questões de caráter individual da relação clínica entre os profissionais de saúde, especialmente os médicos e os enfermos, enfocando primordialmente as situações limites apontadas (PESSINI e BARCHIFONTAINE 2000).

Também não se pode esquecer que nas décadas de 60 e 70 a biomedicina experimenta um grande avanço tecnológico com o evento da diálise em 1962, em Seattle (EUA) e com o comitê que deveria escolher quem poderia ter acesso ao novo recurso terapêutico; o transplante de órgãos revolucionando o conceito de morte; o advento do diagnóstico pré-natal de algumas patologias aliado à possibilidade de abortos em condições clinicamente seguras; as pílulas contraceptivas e os primeiros passos da reprodução assistida, tornando possível dissociar o que parecia indissolúvel; a expansão do uso das unidades de cuidados intensivos e dos respiradores e o alvorecer da engenharia genética. Ao lado deste desenvolvimento biotecnológico surgem as denúncias feitas por $\mathrm{H}$. Beecher em artigo publicado no New England Journal of Medicine, em 1966, de 22 pesquisas eticamente incorretas realizadas com seres humanos, mesmo após o advento do Código de Nürenberg, em 1947, e a Declaração de Helsinque, em 1964. Estes fatos, além de escandalizarem a opinião pública, colocam em questionamento a medicina e a ética.

Por isto, frente a este contexto delineado pela preocupação inicial de Potter ao cunhar o neologismo bioética e pelo uso atribuído à palavra por Hellengers, alguns autores destacam dentre as motivações que explicam a gênese e o desenvolvimento da bioética os avanços no campo da biologia molecular e na ecologia, a crescente preocupação com o futuro da vida no planeta e a transformação ocorrida na prática da assistência médico-sanitária com a incorporação das conquistas propiciadas pelo desenvolvimento da tecnociência biomédica (GRACIA 1998a; ALMEIDA e SCHRAMM 1999; PESSINI e BARCHIFONTAINE 2000).

A partir dos anos 80, a bioética começa a ampliar seu foco de visão situando a relação clínica no contexto de um sistema de saúde e incorporando a reflexão das 
questões relativas à estrutura, à gestão e ao financiamento deste sistema. Neste periodo, a difusão da bioética em direção aos países do hemisfério sul, especialmente a América Latina, onde convivem ilhas de excelência tecnológica em saúde com a extrema pobreza da maioria das populações, torna imperativa a inclusão dos problemas da coletividade na agenda das discussões, com temas como o acesso aos serviços de saúde, a alocação de recursos em saúde, as questões demográficas e populacionais e a responsabilidade social e coletiva sobre as condições de saúde. Tanto é assim, que o Programa Regional de Bioética para a América Latina e Caribe, desde seu estabelecimento pela Organização Pan-americana da Saúde, em 1994, define dentre as prioridades temáticas em bioética para a Região, a ética em Saúde Pública (PESSINI e BARCHIFONTAINE 2000).

No final da década de 90, como lembra Wikler (1997) citado por Pessini e Barchifontaine (2000, p. 395 e 396), inicia-se a chamada bioética da saúde da população, entrando em cena com mais vigor os direitos humanos e as Ciências Sociais e Humanas. Confere-se, desta maneira, maior destaque às questões da eqüidade e da alocação de recursos na saúde.

Caracteriza este momento da bioética:

- A perda do lugar central que vem sendo ocupado pela medicina de alta tecnologia, com desvio do enfoque central das questões relativas ao avanço biotecnológico em direção aos determinantes da saúde, dentre os quais figura o acesso aos serviços de saúde e à tecnologia neles incorporada;

- A ênfase igualmente colocada na saúde e nos cuidados à saúde, com a preocupação voltada não apenas para quem tem acesso a determinados serviços sanitários, mas também para quem adoece ou não e o quão eqüitativa mostra-se esta relação;

- A preocupação com as questões demográficas;

- A priorização dos excluídos nos países em desenvolvimento; 
- A necessidade de um novo marco conceitual que, apropriando-se de conceitos e teorias de outros campos do conhecimento humano, dê conta das demandas de reflexão geradas por esta bioética da saúde das populações.

A partir desta trajetória histórica é possivel compreender porque a bioética, no contexto internacional e brasileiro, tem sistematicamente deixado de lado não somente as questões relativas à Saúde Pública e Coletiva, mas também porque tem se dedicado muito mais à reflexão e discussão dos problemas de ordem ética enfrentados pelos profissionais da saúde que atuam nos hospitais e outros serviços de saúde que concentram a incorporação de alta tecnologia, relegando ao esquecimento a vertente da atenção básica, mormente composta pelas unidades básicas de saúde responsáveis pelas ações e pelos procedimentos tidos como de mais baixa complexidade ${ }^{1}$.

Segundo Gracia (1998b), a sofisticação tecnológica alcançada nos hospitais e serviços especializados, nas três últimas décadas, tem sido uma das motivações mais evidentes do desenvolvimento da bioética e isto explica porque as publicações e os procedimentos de tomada de decisão difundidos durante este periodo centram-se, fundamentalmente, nos casos de situação limite. Segue o autor afirmando que até mesmo a teoria bioética mais difundida, o principialismo, e a linguagem ética dos principios e das conseqüências tem sido pensada em função da tomada de decisão em circunstâncias peremptórias que exigem uma resposta rápida, mais apropriada a este tipo de cenário.

\footnotetext{
${ }^{1} \mathrm{Na}$ atenção básica compreende-se, segundo a Norma Operacional Básica 01/96 do Ministério da Saúde, as consultas médicas em especialidades básicas; atendimento odontológico básico (procedimentos coletivos, procedimentos individuais preventivos, dentística e odontologia cirúrgica básica); atendimentos básicos por outros profissionais de nível superior; visita/atendimento ambulatorial e domiciliar por membros da equipe de saúde da familia; vacinação; atividades educativas a grupos da comunidade; assistência pré-natal; atividades de planejamento familiar; pequenas cirurgias; atendimentos básicos por profissional de nivel médio; atividades dos agentes comunitários de saúde; orientação nutricional e alimentar ambulatorial e comunitária; assistência ao parto domiciliar por médico do Programa Saúde da Família; e atividades de pronto atendimento. Ainda pode-se incluir ações no campo da Vigilância Sanitária, Assistência Farmacêutica Básica e Saúde da Familia, incorporando e integrando ações isoladas de Agentes Comunitários de Saúde (PACS) e Combate às Carências Nutricionais.
} 
Este privilégio da assistência altamente especializada em detrimento da vertente da atenção básica à saúde tem sido tomado em conta por alguns autores, levando-os a classificar o atual entendimento da bioética de incompleto:

\begin{abstract}
"The current understanding of bioethics is (....) incomplete as it largely ignores the health encounters of the primary care and non medical healthcare settings. Rather, the vast preponderance of philosophical inquiry and empirical ethical research focuses on dilemmas arising in hospitals and tertiary care institutions." (FETTERS e BRODY 1999).
\end{abstract}

E, ao se ponderar as considerações de Gracia (1998b) que apresenta a bioética como uma disciplina que tem por objeto o estudo dos valores e sua inclusão no processo de tomada de decisão, o que lhe imprime um caráter eminentemente prático e operativo com um olhar voltado para os fatos, parece que se pode concordar com a idéia de incompletude defendida no parágrafo anterior.

Se a tomada de decisão deve levar em conta os fatos, ou seja, os dados da situação descrita de modo mais completo possivel, buscando analisar os valores que os acompanham e integrá-los no processo decisório a fim de aumentar sua qualidade e propiciar decisões não apenas tecnicamente corretas, mas eticamente adequadas, ao centrar-se nos casos de situação limite na atenção à saúde a bioética esquece que a assistência médico-sanitária não se configura como um conjunto homogêneo de serviços e ações. Parece, então, que uma parte dos fatos não é considerada no contexto que rodeia o processo decisório. Esta incompletude aumenta de proporção se for considerado que a saúde tem sido equiparada em bioética, muitas vezes, ao acesso a serviços sanitários, desconsiderando-se a questão dos determinantes e condicionantes sociais do processo saúde-doença.

Sem desconhecer a relevância dos temas tratados mais enfaticamente pela bioética até agora, é mister ampliar e redirecionar as atuais orientações. Esta tarefa torna-se mais urgente ainda para os que estudam e refletem bioética no Brasil. Isto 
porque, como alerta Clotet (1995), da forma que vem sendo tratada, a bioética tem se ocupado de problemas que afetam apenas um número reduzido de pessoas nos países ricos, o que pode lhe impor o risco de isolar-se do fluxo de exigências e experiências comuns a todos e/ou que dizem respeito aos grupos menos privilegiados de países pobres.

Entretanto, esta incumbência não é nada fácil, uma vez que o viés observado nas situações tratadas pela bioética parece não constituir fato isolado, apresentandose, provavelmente, como reprodução das tendências observadas na organização dos serviços de saúde no Brasil. Como assinala Elias (1999), não configura situação rara a absorção de importante quantidade dos recursos destinados à área da saúde pelos hospitais especializados sem a compatível correspondência na resolução dos problemas de saúde mais demandados pela população. Como destaca o autor, a realidade brasileira acompanha o que ocorre nos paises em desenvolvimento, onde os estabelecimentos, os equipamentos, os recursos humanos e os medicamentos tendem a orientar-se para a esfera que concentra os atendimentos de maior complexidade.

E, é justamente nestes pólos que a bioética tem se desenvolvido no Brasil. Ao se deslindar o rol dos centros apontados por Clotet (1995) como os pioneiros desta temática no país, embora sejam encontrados alguns grupos vinculados à Saúde Pública, percebe-se a concentração junto aos hospitais universitários, ícones da alta complexidade na assistência à saúde.

De acordo com Brody (1989); Gracia (1998b); Fetters e Brody (1999) e Mayer-Braunack (2001), alguns fatores indicam que os problemas éticos enfrentados na atenção básica devem diferir dos identificados nas demais esferas de atendimento:

- Os problemas de saúde encontrados nos diversos serviços de assistência diferem segundo o nivel das ações e dos procedimentos oferecidos;

- Os sujeitos éticos, isto é, os usuários, os familiares e os profissionais de saúde também são diferentes. Os usuários de um serviço de saúde hospitalar, pela própria condição da internação, estão com sua autonomia mais comprometida do que os não hospitalizados. Os profissionais de 
saúde, na atenção básica, usualmente visam objetivos de mais longo prazo, como a transformação dos perfis epidemiológicos da coletividade a partir da atenção integral e não apenas o tratamento de um problema pontual;

- O cenário em cada tipo de serviço de saúde difere e isto tem importância na medida em que os problemas de ordem ética emergem do contexto no qual se inserem. Nas unidades básicas de saúde, os encontros entre os profissionais de saúde e os usuários são mais freqüentes e em situações de menor urgência. Assim, a emergência, a imediatidade e a dramaticidade das situações vivenciadas, por exemplo, nos prontos socorros ou unidades de terapia intensiva fazem com que os problemas éticos sejam freqüentemente mais evidentes, tempestuosos e avultados, enquanto nas unidades básicas de saúde apresentam-se tipicamente de maneira mais sutil, passando, muitas vezes, desapercebidos;

- As soluções encontradas para problemas éticos similares podem diferir nos diversos serviços de atenção à saúde, pois ainda que se observe a mesma estrutura de raciocínio ético, os sujeitos éticos e o contexto são distintos, ou seja, os inputs do processo decisório distinguem-se.

Assim, a partir destas considerações pode-se concluir com Gracia (1998b) que:

“(...) resulta evidente que la medicina primaria no sólo maneja unos hechos distintos que los de la terciaria, sino también un mundo de valores de mayor amplitud y complejidad. (....) Dicho de otra manera, la medicina primaria exige un manejo de la bioética clínica que no es distinto, pero sí superior o más complejo que el de la medicina terciaria. Esto da buena idea de la importancia de la formación en bioética en los programas de medicina familiar e comunitaria." (GRACIA 1998b, p. 100 - 1). 
Com efeito, das poucas pesquisas desenvolvidas para identificar os problemas de ordem ética vivenciados na atenção básica, algumas apontam para diferenças em relação as demais esferas da assistência à saúde. No entanto, cabem algumas considerações em relação a estas investigações. Utilizam, geralmente, padrões ideais desenvolvidos através de exame de casos no ambiente hospitalar para a identificação dos problemas éticos e os autores partem de suas próprias percepções para definir o que constitui uma questão ética de relevância. Desta forma, são necessárias pesquisas que busquem identificar os problemas éticos na atenção básica, especialmente nas unidades básicas de saúde (KNABE, STEARNS e GLASSER 1994; WAGNER e RONEN 1996; FETTERS e BRODY 1999).

A este ponto parece pertinente ponderar que os problemas de ordem ética vivenciados na atenção básica não podem ser tratados sem se considerar o contexto do sistema de saúde. Isto porque, como assinala Elias (1999), há uma relação de interação entre a organização de serviços e o sistema da saúde. Afirma o autor que, se por um lado os serviços estruturam-se a partir das características gerais dos sistemas de saúde, de outro, é o conjunto destes serviços que acaba por conformar a estrutura dos sistemas.

No Brasil, a saúde estrutura-se sob a égide do Sistema Único de Saúde (SUS) criado pela Constituição Federal de 1988, que contempla a saúde como direito social e dever do Estado. O SUS tem como seus pilares básicos a universalidade no acesso aos serviços, a igualdade no atendimento e a eqüidade na distribuição dos recursos. A sua organização pauta-se pelas diretrizes da descentralização e hierarquização com direção única em cada esfera do governo (federal, estadual e municipal); do atendimento integral que compatibiliza as atividades preventivas e assistenciais e do controle exercido pela sociedade através da participação da comunidade nas conferências e conselhos de saúde. O SUS é regulamentado pelas Leis $\mathrm{n}^{\circ} 8080$, de 19/9/90 e n 8142, de 28/12/90, que conformam a Lei Orgânica da Saúde (LOS) na qual se encontra o detalhamento destas diretrizes e da operacionalização de alguns aspectos do sistema (ELIAS 1999). 
O SUS corresponde à constitucionalização das principais bandeiras do Movimento pela Reforma Sanitária que, iniciado na década de 70 com a mobilização de diversos segmentos da sociedade que arriscavam denunciar o descalabro do sistema de saúde, defendia o fortalecimento do setor público nesta área como um direito de cidadania (COHN 1999).

Entretanto, apesar da saúde ter seu arcabouço legal mínimo definido desde a década de 90 , suas conseqüências ainda não surtiram os efeitos desejados, previstos e necessários para dar conta da estruturação e do funcionamento plenos dos SUS. A descentralização concretiza-se de forma limitada e limitante, pois é tutelada pela esfera federal, operada por meio de financiamento e demarcada muito mais por seu componente racionalizador do que pelas possibilidades de democratização da instância municipal. Persistem os problemas relativos ao financiamento e o controle social ainda tenta consolidar-se abrindo caminhos no seio de uma sociedade desestimulada e desacostumada às ações de cidadania e de um Estado hostil à idéia de ter seus atos fiscalizados pela sociedade (ELIAS 1999).

Isto remete à reflexão de que a implementação do SUS, em verdade, configura um processo que requer uma reviravolta ética, pois implica em um processo social de mudança na prática sanitária que exige dos atores envolvidos, como os profissionais de saúde, os gestores e os usuários transformações atitudinais e culturais. Neste sentido, discutindo a ética na produção social de saúde, Garrafa (1995) alerta que:

"Qualquer processo dinâmico que procure mudanças substanciais e envolva diferentes interesses e pessoas, exige dos seus executores e beneficiários alguns câmbios atitudinais e até mesmo culturais. Colocado desta maneira, esse processo é substancialmente ético e deve passar por profundos estudos e reavaliações nas posturas, nos direitos e nas obrigações dos atores com ele comprometidos; no caso, refiro-me aos políticos e técnicos que manejam os 
recursos para a saúde, aos trabalhadores da área e aos usuários." (GARRAFA 1995, p. 30).

No próprio arcabouço legal que dá sustentação ao SUS já se encontra expressa a preocupação com a necessidade de definir-se padrões éticos para a pesquisa, as ações e os serviços de saúde (alínea XVII do artigo 15 da Lei ${ }^{\circ}{ }^{8080}$ ). Antes disso, no relatório final da $8^{\mathrm{a}}$ Conferência Nacional de Saúde, marco significativo da Reforma Sanitária brasileira, defende-se que o novo sistema nacional de saúde deve reger-se pelo respeito à dignidade dos usuários e pelo compromisso dos profissionais com estes.

No caso específico do Estado de São Paulo, o Código de Saúde definido pela Lei Complementar 791, de 09 de março de 1995 confere fortalecimento aos usuários dos serviços de saúde ao assegurar-lhes, de maneira especial, os direitos individuais à informação e à liberdade de decisão para aceitar ou não a assistência proposta (GOUVEIA e FORTES 2000).

Entretanto, apesar desta centralidade da preocupação ética e de se reconhecer que a efetivação do SUS implica um processo ético de mudança atitudinal dos diversos atores envolvidos, pouco se tem trabalhado no campo da saúde pública acerca dos papéis e das responsabilidades éticas de cada um (GARRAFA 1995).

Para fazer frente ao desafio de concretização do SUS, parece patente a urgência de se lidar com os problemas de ordem ética vivenciados nos serviços e sistema de saúde, especialmente na atenção básica que, mesmo representando, como registra Elias (1999), 78\% dos estabelecimentos de saúde, tem sido preterida no campo das reflexões bioéticas.

Enfrentar este desafio também requer investigar outra questão ainda relativamente inexplorada na pesquisa em bioética. Segundo Richter e Eisemann (2000), ainda são poucos os estudos que buscam reconhecer os critérios e fundamentos que determinam ou influenciam as decisões dos profissionais de saúde. 
Investigar este ponto é essencial, pois, segundo Lefêvre e cols (2000), para se trabalhar educativamente com os profissionais de saúde e/ou com a população é importante tornar manifestas, para eles, as teorias, ideologias e conceitos que, na maioria das vezes, inconscientemente, estão subjacentes às práticas cotidianas profissionais.

Os problemas surgem em distintos âmbitos da vida social, dotados de peculiaridades próprias. Não se trata, assim, de aplicar princípios gerais a casos concretos, nem tampouco de induzir tais princípios a partir das decisões concretas, mas de descobrir nos distintos âmbitos a peculiar modulação dos princípios. Uma das exigências da ética aplicada é adentrar em cada um dos âmbitos e tentar captar nele sua própria lógica e modulação de princípios éticos que lhe é peculiar, e quem pode fazer isto são os expertos em cada campo, com estreita colaboração de quem se ocupa da ética (CORTINA 1997a):

(....) pasaron los tiempos "platónicos", en los que parecía que el ético descubría unos principios y después los aplicaba sin matizaciones urbi et orbe. Mas bien hoy enseña la realidad a ser muy modestos y a buscar junto con los especialistas de cada campo que principios se perfilan en él y cómo deben aplicarse en los distintos contextos (CORTINA 1997a, p. 175).

A bioética, como uma ética aplicada, para ser capaz de transformar qualitativamente a atenção à saúde deve também percorrer este caminho. Assim, o presente estudo pretende ser um adentrar no âmbito da saúde pública para uma aproximação inicial às questões éticas que se amalgamam no contexto da atenção realizada na unidade básica de saúde, buscando identificar, junto aos profissionais que atuam nesta esfera do atendimento, os problemas éticos enfrentados e os fundamentos dos quais lançam mão para solucioná-los. Espera-se poder contribuir 
para uma tomada de decisão adequada a esta realidade e que também potencialize a resolução dos problemas éticos nela emersos. 


\section{OBJETIVOS}

1 - Identificar problemas éticos vivenciados por enfermeiros e médicos que atuam no Programa Saúde da Família.

2 - Comparar os problemas éticos vivenciados por enfermeiros e médicos que atuam no Programa Saúde da Família.

3 - Identificar os fundamentos que balizam o equacionamento para o processo de tomada de decisão frente a problemas éticos do cotidiano de enfermeiros e médicos que atuam no Programa Saúde da Família.

4 - Comparar os fundamentos que balizam o equacionamento para o processo de tomada de decisão frente a problemas éticos do cotidiano de enfermeiros e médicos que atuam no Programa Saúde da Família. 


\section{PROCEDIMENTOS METODOLÓGICOS}

\subsection{TIPO DE ESTUDO}

Optou, neste estudo, por trilhar os caminhos da abordagem qualitativa, pois o fenômeno investigado, problemas éticos, situa-se no universo de significados, motivações, aspirações, crenças, valores e atitudes e é próprio das pesquisas qualitativas buscar compreender este espaço mais profundo das relações, dos processos e dos fenômenos, que dificilmente pode ser reduzido à operacionalização de variáveis típica das abordagens quantitativas. Segundo Minayo (1996a) é a pesquisa qualitativa que permite incorporar a questão do significado e da intencionalidade como inerentes aos atos, às relações e às estruturas sociais.

Além disto, como frisam Fetters e Brody (1999), a complexidade e a sutileza que cercam os problemas éticos que emergem da atenção em unidades básicas de saúde requerem abordagens qualitativas capazes de elucidá-las.

Assim, esta pesquisa configura-se como um estudo qualitativo, de cunho descritivo. Situa-se no escopo da ética descritiva, enquanto uma pesquisa empírica, de cunho não normativo.

A este ponto merece consideração o lugar dos estudos descritivos nas pesquisas que têm como objeto a ética ou a moral. Para tal empreitada, é necessário ter presente a distinção entre ética e moral, mencionada na introdução deste trabalho, que toma a ética como o estudo (pesquisa e sistematização) da moral (prática).

Sulmasy e Sugarman (2001), citando Frankena (1973), afirmam que há três tipos básicos de indagação ética: ética normativa, metaética e ética descritiva. Beauchamp e Childress (2001) tambẻm reconhecem estes três tipos de indagação, 
considerando, ainda, que a metaética e a ética descritiva constituem abordagens não normativas da ética.

A abordagem normativa empenha-se em responder as questões relativas à quais são as normas que devem ser aceitas para avaliar as condutas e as razões para isso. Dirige-se, deliberada e conscientemente, para a questão da validez dos princípios morais. Conforma a busca dos fundamentos das normas e dos valores, o que a associa, indissoluvelmente, à crítica, ou seja, ao permanente questionamento de cada fundamentação. As teorias e os princípios constituem ponto de partida para o desenvolvimento de normas de conduta apropriadas que são suplementadas por casos paradigmáticos exemplificativos da maneira correta de agir e por uma defesa ou justificação da aceitação de tais princípios (MALIANDI 1991, BEAUCHAMP e CHILDRESS 2001, SULMASY e SUGARMAN 2001).

A metaética envolve a análise da linguagem, ou seja, a investigação do sentido e significado dos termos morais, a lógica e lingüística do equacionamento moral e as questões fundamentais de ontologia moral, epistemologia e justificação. Assim, não consiste em investigações e teorias empiricas ou históricas, não implica em estabelecer ou defender quaisquer juízos normativos ou de valor e não trata de responder a perguntas particulares ou gerais acerca do que é justo, bom ou obrigatório. Mas antes, empreende a busca de respostas a questões lógicas, epistemológicas ou semânticas, do tipo 'qual o sentido ou o emprego das expressões moralmente justo ou bom?' (BEAUCHAMP e CHILDRESS 2001, SULMASY e SUGARMAN 2001).

A ética descritiva, por sua vez, é a investigação factual da conduta moral, utilizando-se de procedimentos e metodologias de cunho científico para estudar como as pessoas equacionam e agem. Assim, não se engaja diretamente em questões do tipo 'o que deve ser feito' ou 'qual o uso apropriado dos termos éticos', mas indaga por 'como as pessoas pensam que deveriam agir nesta situação particular que é objeto de preocupação normativa?' ou 'que fatos são relevantes para esta questão da ética normativa?' ou ainda 'como as pessoas realmente se comportam nesta 
circunstância particular que traz problemas éticos?'. O ethos, entendido como conjunto de atitudes, conviç̧ões, crenças morais e formas de conduta, seja da pessoa individual ou de um grupo social, étnico etc. é o objeto da investigação, procedendose a sua observação e descrição. Este tipo de pesquisa constitui tarefa científica e não filosófica, requerendo instrumental e metodologias de natureza científica. Caracteriza, de forma paradigmática, o aporte que a ciência proporciona à reflexão filosófica, podendo suas observações, ao tratar de extrair informação da facticidade normativa, serem proveitosamente utilizadas na ética normativa (MALIANDI 1991, BEAUCHAMP e CHILDRESS 2001, SULMASY e SUGARMAN 2001).

Ainda é pertinente localizar as investigações descritivas em ética no campo da bioética, uma vez que o presente estudo busca nessa abordagem secular, interdisciplinar, prospectiva e global da ética em saúde seu prisma norteador. Segundo Sánchez-González (1998), nos anos 70, como predominam na produção literária de bioética os teólogos, filósofos e juristas, as obras desse período consistem em ensaios teóricos que analisam os problemas utilizando métodos próprios dessas disciplinas. A partir da década de 80 , ao se incorporarem à bioética os médicos e os cientistas sociais, são introduzidos novos tipos de investigação que aplicam os métodos empíricos das ciências sociais e da epidemiologia, desenvolvendo-se novas linhas metodológicas. Cresce, assim, o interesse por conduzir investigações empíricas na bioética, como assinala Haimes (2002).

A pesquisa teórica, de natureza normativa e desenvolvida em níveis mais genéricos, inclui as investigações de cunho teológico, filosófico, jurídico e político. Emprega a argumentação lógica, com vistas a definir conceitos, estruturar argumentos consistentes e elaborar recomendações. Por outro lado, a investigação empírica, que lança mão de procedimentos próprios das ciências sociais, da análise decisória, da epidemiologia e da avaliação de serviços de saúde, recolhe e analisa dados a fim de descrever e estudar como se tomam as decisões, que valores estão subjacentes a estas, como se cumprem na prática as normas ou as diretrizes éticas. Constitui-se, assim, uma abordagem de natureza descritiva e que se move, preferentemente, no nível mais concreto (SÁNCHEZ-GONZÁLEZ 1998). 
A pesquisa empírica, de cunho não normativo, segundo Sánchez-González (1998), tem como funções:

- identificar e caracterizar os problemas éticos que emergem na prática da atenção à saúde, permitindo elaborar uma bioética centrada nos problemas reais;

- descrever como se lidam habitualmente com os problemas, podendo constituir esta descrição objeto de crítica ou ponto de partida para a propositura de soluções alternativas;

- descobrir as conseqüências das ações e das normas aceitas, estabelecendo uma forte interface com a ética normativa que também tem a avaliação das conseqüências como seu objeto;

- evidenciar deficiências nas teorias éticas e provocar a revisão das mesmas.

Ambos os tipos de pesquisa conformam pilares fundamentais da bioética atual, dependem uma da outra e nutrem-se mutuamente, pois, como alerta Haimes (2002), não é possível conduzir uma pesquisa empírica de boa qualidade sem estar bem informado acerca de alguma teoria e, igualmente, não se pode entender as explanações teóricas sem compreender como o mundo empírico cotidiano opera.

Discutindo os diferentes tipos de indagação ética - a normativa, a metaética e a descritiva - Sulmasy e Sugarman (2001) afirmam a igual importância dos três e reconhecem a centralidade do primeiro. Segundo os autores, com isto não querem sugerir que este seja mais intelectual ou valioso, mas que os demais são importantes, significativos e úteis porque há questões normativas em jogo. Em outras palavras, a indagação 'o que a palavra deve significar' é feita porque há interesse em saber o que se deve fazer. Da mesma maneira, o empenho em conhecer o pensamento da população sobre o que deve ser feito em determinadas circunstâncias ou como as pessoas realmente comportam-se em tais ocasiões surge frente a situações para as quais há diretrizes morais que determinam como elas deveriam agir. Entretanto, a 
despeito desta essencialidade da ética normativa, os três são necessários porque propiciam perspectivas distintas do mesmo objeto.

Entre a ética normativa e a descritiva instaura-se uma retroalimentação de mão dupla. A primeira pode gerar explanações que estão associadas com hipóteses passíveis de testes empíricos ou estabelecer padrões normativos que têm de ser operacionalizados e podem ser estudados nos cenários da educação e da prática. As lições empíricas obtidas de tais estudos podem, por sua vez, retroalimentar e influenciar as teorias normativas. Os argumentos normativos também podem depender de fatos possíveis de serem acumulados das investigações empíricas e que lhes fornecem sustentação ou refutação. A ética descritiva ainda pode proporcionar novo material para estudos normativos, por exemplo, estudos antropológicos e sociológicos podem levantar questões sobre a universalidade de explanações normativas e os estudos de casos podem sugerir questões jamais tratadas por investigações normativas ou suprir uma base para a casuística e a narrativa (SULMASY e SUGARMAN 2001).

Para Sulmasy e Sugarman (2001), os diversos tipos de pesquisa estimulam-se mutuamente, ou seja, bons estudos em ética normativa estarão fundamentados em bons dados empíricos e bons estudos descritivos estarão pautados pela teoria ética que provê uma estrutura na qual os dados serão interpretados. Esta integração assumida de maneira interdisciplinar e cooperativa é que possibilitará, para os autores, a reflexão ética. 


\subsection{SUJEITOS DO ESTUDO}

Foram entrevistados 18 enfermeiros e 17 médicos que trabalham em unidades básicas de saúde do Município de São Paulo e que contam com Programa Saúde da Familia (PSF) implantado. A opção por estas unidades justifica-se pelo fato de ser o PSF a estratégia preconizada pelo Ministério da Saúde para a reorganização da atenção básica no SUS.

Segundo determinações da Resolução CNS/MS 196/96, que regulamenta a ética da pesquisa envolvendo seres humanos no Brasil, a cada um dos sujeitos foi pedido seu consentimento livre e esclarecido como anuência para participação na pesquisa. No entanto, este consentimento não foi registrado mediante um termo escrito, mas tomado oralmente, ou seja, o próprio depoimento gravado foi tido como a concordância do sujeito em participar do estudo. Este procedimento visou garantir o anonimato dos sujeitos participantes e assegurar que se sentissem protegidos e seguros para abordar as questões sigilosas que podem permear os problemas éticos relatados, isto é, propiciava-se aos sujeitos as condições para que permanecessem anônimos durante todo o processo.

Em lugar do Termo de Consentimento Livre e Esclarecido entregou-se a cada sujeito um Termo de Responsabilidade (anexo 1) assinado pela pesquisadora e seu orientador, que continha os objetivos da pesquisa; o que se demandava do sujeito; as garantias para a preservação de seu anonimato, bem como das pessoas e das instituições que pudessem estar envolvidas nos casos narrados, com a omissão de nomes e a exclusão de particularidades que possibilitassem a identificação. Neste documento indicou-se uma forma de contato com a pesquisadora para esclarecimentos de dúvidas, se necessário. Também se assegurou a liberdade de participação, de recusa e o direito do sujeito retirar-se a qualquer momento da pesquisa sem que isto lhe causasse prejuízos. 
Visando preservar a privacidade dos sujeitos da pesquisa ofereceu-se a possibilidade da entrevista ser realizada fora da unidade de saúde. Dois enfermeiros fizeram essa opção por estarem freqüentando cursos nas imediações da Escola de Enfermagem da Universidade de São Paulo e entenderem que seria mais fácil ter tempo para a entrevista nesses dias do que na rotina da unidade de saúde.

Às coordenações central e regionais e à direção das unidades básicas de saúde nas quais os sujeitos trabalhavam também solicitou-se autorização para a realização da pesquisa mediante termo de consentimento institucional semelhante ao entregue aos sujeitos, no qual se explicitava que não thes seria revelado nenhum dado das entrevistas isoladamente e tampouco a decisão individual dos profissionais de participarem ou não das entrevistas (anexo 2). $\mathrm{O}$ anonimato das unidades participantes também garantiu-se pelos mesmos motivos ponderados para os sujeitos. Além disto, uma vez que o agir ético dos que trabalham em uma instituição conformam a sua imagem ética, parece que estas, em certa medida, assumiram um status de sujeitos de pesquisa também.

O documento de consentimento assinado pela coordenação central tinha como objetivo afiançar aos diretores das unidades de saúde que a entrada na instituição estava autorizada, ficando este à disposição para ser apresentado quando fosse solicitado. Vale registrar que este procedimento foi necessário somente uma vez, pois a própria coordenação central notificou através de oficio a autorização para o contato da pesquisadora com as unidades e os profissionais dentro dos termos acordados.

O projeto foi apreciado e aprovado pelo Comitê de Ética em Pesquisa da Faculdade de Saúde Pública da Universidade de São Paulo (anexo 3). 


\subsubsection{PERFIL DOS ENFERMEIROS ENTREVISTADOS}

Um total de 18 enfermeiros foi entrevistado, sendo somente um do sexo masculino, conforme pode ser observado no quadro apresentado a seguir. A idade média é de aproximadamente 30 anos, com os extremos de 53 e 22 e com $57,9 \%$ (11) até 29 anos e 26,3\% (5) na faixa etária de 30 a 39.

No momento da entrevista, o tempo de trabalho como enfermeiro varia de 21 anos a 4 meses, com $61,1 \%$ (18) até 4 anos. $O$ tempo no PSF vai de 2 meses a 4 anos, com $27,8 \%$ (5) com menos de 1 ano. Em relação a essa questão, vale assinalar que o PSF pode estar se constituindo uma opção de ingresso no mercado de trabalho para os recém graduados, pois se nota, para boa parte dos enfermeiros entrevistados ( $7 \mathrm{em}$ 17), uma coincidência ou grande proximidade entre os tempos de trabalho como enfermeiro e no PSF. Nesse sentido, cabe esclarecer que no quadro está sendo considerado, para efeitos de contagem como tempo de trabalho no PSF, apenas o período relativo à atuação dos profissionais no Município de São Paulo. Assim, há enfermeiros que contam com tempo anterior de trabalho no PSF de outras cidades, como Mauá (São Paulo), Ilhéus (Bahia) e Recife (Pernambuco).

A entrevista do enfermeiro número 4 não é considerada pelo fato deste profissional atuar em unidade de saúde não pertencente à parcela da rede de serviços delimitada para seleção dos sujeitos, tendo servido apenas como pré-teste. As numerações originais de identificação atribuídas a cada depoente no momento da gravação das entrevistas são mantidas, o que explica a quebra da seqüência numérica no quadro. 
QUADRO 1 - ENFERMEIROS ENTREVISTADOS SEGUNDO SEXO, IDADE E TEMPO DE TRABALHO

\begin{tabular}{|c|c|c|c|c|}
\hline IDENTICAÇÃO & SEXO & $\begin{array}{l}\text { IDADE } \\
\text { (ANOS) }\end{array}$ & $\begin{array}{c}\text { TEMPO DE } \\
\text { TRABALHO } \\
\text { COMO } \\
\text { ENFERMEIRO }\end{array}$ & $\begin{array}{c}\text { TEMPO DE } \\
\text { TRABALHO } \\
\text { NO PSF }\end{array}$ \\
\hline $\begin{array}{l}\text { ENFERMEIRO } 1 \\
\text { (E1) }\end{array}$ & Feminino & 53 & 21 Anos & $\begin{array}{c}3 \text { Anos e } 6 \\
\text { Meses }\end{array}$ \\
\hline $\begin{array}{l}\text { ENFERMEIRO } 2 \\
\text { (E2) }\end{array}$ & Feminino & 26 & 2 Anos e 6 Meses & 1 Ano e 6 Meses \\
\hline $\begin{array}{c}\text { ENFERMEIRO } 3 \\
\text { (E3) }\end{array}$ & Feminino & 24 & 2 Anos e 3 Meses & $\begin{array}{c}2 \text { Anos e } 3 \\
\text { Meses }\end{array}$ \\
\hline $\begin{array}{l}\text { ENFERMEIRO } 5 \\
\text { (E5) }\end{array}$ & Feminino & 28 & 4 Anos & 4 Anos \\
\hline $\begin{array}{c}\text { ENFERMEIRO } 6 \\
\text { (E6) }\end{array}$ & Feminino & 29 & 2 Anos & 3 Meses \\
\hline $\begin{array}{l}\text { ENFERMEIRO } 7 \\
\text { (E7) }\end{array}$ & Feminino & 22 & 4 Meses & 2 Meses \\
\hline $\begin{array}{l}\text { ENFERMEIRO } 8 \\
\text { (E8) }\end{array}$ & Feminino & 28 & 3 Anos & $\begin{array}{c}2 \text { Anos e } 3 \\
\text { Meses }\end{array}$ \\
\hline $\begin{array}{c}\text { ENFERMEIRO } 9 \\
\text { (E9) }\end{array}$ & Masculino & 30 & 2 Anos e 6 Meses & 3 Meses \\
\hline $\begin{array}{l}\text { ENFERMEIRO } 10 \\
\text { (E10) }\end{array}$ & Feminino & 26 & 3 Anos e 7 Meses & $\begin{array}{c}3 \text { Anos e } 7 \\
\text { Meses }\end{array}$ \\
\hline $\begin{array}{l}\text { ENFERMEIRO } 11 \\
\text { (E11) }\end{array}$ & Feminino & 32 & 7 Anos & 2 Meses \\
\hline $\begin{array}{c}\text { ENFERMEIRO } 12 \\
\text { (E12) }\end{array}$ & Feminino & 32 & 5 Anos & 2 Anos \\
\hline $\begin{array}{c}\text { ENFERMEIRO } 13 \\
\text { (E13) }\end{array}$ & Feminino & 30 & 4 Anos & $\begin{array}{l}3 \text { Anos e } 6 \\
\text { Meses }\end{array}$ \\
\hline $\begin{array}{l}\text { ENFERMEIRO } 14 \\
\text { (E14) }\end{array}$ & Feminino & 28 & 4 Anos & $\begin{array}{l}3 \text { Anos e } 5 \\
\text { Meses }\end{array}$ \\
\hline $\begin{array}{l}\text { ENFERMEIRO } 15 \\
\text { (E15) }\end{array}$ & Feminino & 27 & 4 Anos & 3 Anos \\
\hline $\begin{array}{l}\text { ENFERMEIRO } 16 \\
\text { (E16) }\end{array}$ & Feminino & 42 & 6 Anos & 4 Anos \\
\hline $\begin{array}{l}\text { ENFERMEIRO } 17 \\
\text { (E17) }\end{array}$ & Feminino & 25 & 3 Anos & 1 Ano \\
\hline $\begin{array}{l}\text { ENFERMEIRO } 18 \\
(\text { E18) }\end{array}$ & Feminino & 35 & 6 Anos & 4 Anos \\
\hline $\begin{array}{l}\text { ENFERMEIRO } 19 \\
(\text { E19) }\end{array}$ & Feminino & 28 & 4 Anos & 4 Anos \\
\hline
\end{tabular}




\subsubsection{PERFIL DOS MÉDICOS ENTREVISTADOS}

Os médicos entrevistados somaram 17, sendo $12(70,6 \%)$ do sexo feminino e cinco $(29,4 \%)$ do sexo masculino, conforme pode ser acompanhado no quadro que segue. A idade média está em torno dos 39 anos, 9 a mais do que o observado para o grupo de enfermeiros. Os extremos variam de 60 a 25 anos, com 17,6\% (3) até 29 anos e na faixa etária de 30 a 39 anos estão $35,3 \%$ (6).

Quanto ao tempo de experiência como médico, no momento da entrevista, esse período está entre os limites de 11 meses e 36 anos, com 64,7\% (11) concentrando-se nas faixas de 5 a 14 e de 15 a 24 anos de formado. O tempo no PSF vai de 4 meses a 4 anos, com $47 \%$ (8) trabalhando há menos de 1 ano. Em relação a isto, chama a atenção que no grupo dos enfermeiros apenas 5 destes profissionais contam como mais de 5 anos de trabalho, enquanto que dentre os médicos a situação é justamente a oposta, somente 2 trabalham há 5 anos ou menos.

O médico número 3 não tem sua entrevista incluída por atuar em unidade de saúde não pertencente à parcela da rede de serviços delimitada para seleção dos sujeitos, tendo servido apenas como pré-teste. Assume-se aqui o mesmo procedimento que no grupo de enfermeiros, as numerações originais de identificação atribuídas no momento da gravação das entrevistas são mantidas para facilitar o manuseio das fitas magnéticas. 
QUADRO 2 - MÉDICOS ENTREVISTADOS SEGUNDO SEXO, IDADE E TEMPO DE TRABALHO

\begin{tabular}{|c|c|c|c|c|}
\hline IDENTICAÇÃO & SEXO & $\begin{array}{l}\text { IDADE } \\
\text { (ANOS) }\end{array}$ & $\begin{array}{c}\text { TEMPO DE } \\
\text { TRABALHO } \\
\text { COMO } \\
\text { MÉDICO }\end{array}$ & $\begin{array}{c}\text { TEMPO DE } \\
\text { TRABALHO } \\
\text { NO PSF }\end{array}$ \\
\hline $\begin{array}{l}\text { MÉDICO } 1 \\
\text { (M1) }\end{array}$ & Masculino & 44 & 20 Anos & 3 Anos \\
\hline $\begin{array}{l}\text { MÉDICO } 2 \\
\text { (M2) }\end{array}$ & Feminino & 53 & 30 Anos & 1 Ano e 6Meses \\
\hline $\begin{array}{l}\text { MÉDICO } 4 \\
\text { (M4) }\end{array}$ & Feminino & 41 & 17 Anos & $\begin{array}{c}3 \text { Anos e } 5 \\
\text { Meses }\end{array}$ \\
\hline $\begin{array}{l}\text { MÉDICO } 5 \\
\text { (M5) }\end{array}$ & Feminino & 27 & 1 Ano & 4 Meses \\
\hline $\begin{array}{l}\text { MÉDICO } 6 \\
\text { (M1) }\end{array}$ & Feminino & 41 & 16 Anos & 2 Meses \\
\hline $\begin{array}{l}\text { MÉDICO } 7 \\
\text { (M7) }\end{array}$ & Feminino & 36 & 8 Anos & $\begin{array}{c}3 \text { Anos e } 7 \\
\text { Meses }\end{array}$ \\
\hline $\begin{array}{l}\text { MÉDICO } 8 \\
\text { (M8) }\end{array}$ & Feminino & 32 & 7 Anos & 2 Anos \\
\hline $\begin{array}{l}\text { MÉDICO } 9 \\
\text { (M9) }\end{array}$ & Masculino & 60 & 36 Anos & $\begin{array}{c}3 \text { Anos e } 6 \\
\text { Meses }\end{array}$ \\
\hline $\begin{array}{l}\text { MÉDICO } 10 \\
\text { (M10) }\end{array}$ & Masculino & 37 & 13 Anos & 1 Ano e 6 Meses \\
\hline $\begin{array}{l}\text { MÉDICO } 11 \\
\text { (M11) }\end{array}$ & Feminino & 25 & 1 Ano e 1 Mês & 8 Meses \\
\hline $\begin{array}{l}\text { MÉDICO } 12 \\
\text { (M12) }\end{array}$ & Feminino & 45 & 21 Anos & 4 Anos \\
\hline $\begin{array}{c}\text { MÉDICO } 13 \\
\text { (M13) }\end{array}$ & Feminino & 33 & 8 Anos & $\begin{array}{c}3 \text { Anos e } 6 \\
\text { Meses }\end{array}$ \\
\hline $\begin{array}{l}\text { MÉDICO } 14 \\
\text { (M14) }\end{array}$ & Feminino & 48 & 22 Anos & 8 Meses \\
\hline $\begin{array}{l}\text { MÉDICO } 15 \\
\text { (M15) }\end{array}$ & Masculino & 29 & 11 Meses & 11 Meses \\
\hline $\begin{array}{l}\text { MÉDICO } 16 \\
\text { (M16) }\end{array}$ & Masculino & 32 & 5 Anos & 6 Meses \\
\hline $\begin{array}{l}\text { MÉDICO } 17 \\
\text { (M17) }\end{array}$ & Feminino & 37 & 13 Anos & 4 Meses \\
\hline $\begin{array}{l}\text { MÉDICO } 18 \\
\text { (M18) }\end{array}$ & Feminino & 48 & 24 Anos & 9 Meses \\
\hline
\end{tabular}




\subsection{CENÁRIO DO ESTUDO}

Em razão das garantias de anonimato dos sujeitos de pesquisa e das unidades de saúde, toma-se como cenário desse estudo o Programa Saúde da Família (PSF) no Municipio de São Paulo. Isso não significa admitir que o total de enfermeiros e médicos entrevistados constitui amostra representativa do universo destes profissionais que trabalham no PSF do Município. A intenção é propiciar breve noção das diretrizes do Programa e das características do trabalho preconizado para a equipe de saúde da família (ESF), além de historiar, de maneira resumida, como vem ocorrendo a sua implantação na cidade a fim de que se possa compreender o caráter alguns dos problemas apontados, bem como a discussão que tomará lugar.

O Programa Saúde da Família é idealizado pelo Ministério da Saúde, em 1993, após os resultados positivos do Programa de Agentes de Saúde do Ceará e do Programa de Agentes Comunitários de Saúde em diversos municípios das regiões Norte e Nordeste do país. Sua oficialização ocorre no ano seguinte e a extensão nacional efetiva do Programa, que desde sua concepção é considerado como um instrumento de reorganização do SUS, da municipalização e da atenção básica, ocorre a partir de 1995 (SILVA e DALMASO 2002).

No Município de São Paulo, o PSF inicia-se em 1996, em três áreas (regiões leste, norte e sudeste), com a denominação de Projeto Qualis, Qualidade Integral em Saúde, diferenciando-se por sua proposta nuclear, por sua forma de gestão em parcerias do Estado com organizaçôes sociais e por inserir-se no contexto geopolítico complexo de uma metrópole como a Capital Paulista, que se caracteriza pela concentração de recursos materiais e humanos na área da saúde e pela desigualdade social e de acesso aos serviços. (SILVA e DALMASO 2002, PMSP 2002).

A partir de 2001, com a mudança da conjuntura política, o PSF ganha novo impulso na Cidade. A Secretaria Municipal de Saúde resolve implantar o SUS, optando pela municipalização plena do sistema e pela Estratégia de Saúde na 
Familia, como base de estruturação da atenção básica. A proposta, assim, prevê estender ao conjunto da população paulistana o que vinha se conformando, até então, como um projeto piloto. Com a deflagração do processo de municipalização dos serviços e ações de saúde, o Projeto Qualis/PSF é municipalizado juntamente com a rede básica estadual (PMSP 2002).

Os pontos centrais do PSF incluem o estabelecimento de vínculos e a criação de laços de compromisso e responsabilidade entre os profissionais de saúde e a população. Como uma estratégia para a reorientação do modelo assistencial na atenção básica à saúde, seu objetivo está na reorganização da prática assistencial em novas bases e critérios, substituindo o modelo tradicional de assistência centrado na cura de doenças e no hospital. A atenção volta-se para a família que é entendida e percebida a partir de seu ambiente fisico e social, o que possibilita às equipes uma compreensão ampliada do processo saúde-doença e da necessidade de intervenções que avancem para além das práticas curativas (SILVA e DALMASO 2002).

Caracterizando-se como uma estratégia que faculta a integração e promove a organização das atividades em um território definido, com vistas ao enfrentamento $\mathrm{e}$ à resolução dos problemas identificados, o PSF assume um conceito ampliado de atenção básica avançando na direção de um sistema de saúde que converge para a qualidade de vida das pessoas e de seu meio ambiente. Assim, a atenção básica é entendida como o conjunto de ações de caráter individual ou coletivo, situadas no primeiro nível de atenção dos sistemas de saúde, voltadas para a promoção da saúde, à prevenção de agravos, ao tratamento e à reabilitação, reportando-se aos princípios do SUS: saúde como direito social; integralidade da assistência; universalidade; eqüidade; resolutividade; inter-setorialidade; humanização do atendimento $\mathrm{e}$ participação social (SILVA e DALMASO 2002).

A Portaria Ministerial n 1886 , de 18 de dezembro de 1997, que aprova as normas e diretrizes do Programa de Agentes Comunitários de Saúde e do Programa Saúde da Familia, define como aspectos que devem caracterizar a reorganização das práticas de trabalho nas unidades de saúde da família: 
- caráter substitutivo das práticas tradicionais das unidades básicas de saúde, complementaridade e hierarquização;

- adscrição de população/territorialização

- programação e planejamento descentralizados

- integralidade de assistência

- abordagem multiprofissional

- estímulo à ação intersetorial

- estímulo à participação e controle social

- educação permanente dos profíssionais das equipes de saúde da família

- adoção de instrumentos permanentes de acompanhamento e avaliação

A efetivação da estratégia passa pela constituição e atuação das equipes de saúde da família compostas por um médico, um enfermeiro, um auxiliar de enfermagem e quatro agentes comunitários de saúde, com responsabilidade por $800 \mathrm{a}$ 1.000 famílias residentes em uma área geográfica determinada (SILVA e DALMASO 2002).

Entretanto, é claro que esta efetivação não se resume a uma nova configuração da equipe técnico-assistencial. Se a construção do SUS configura um processo de reviravolta ética, como aludido na introdução desse trabalho, sua reorganização pela estratégia do PSF somente amplia e aprofunda o trajeto desse giro ético. Nesse sentido, Sousa (2002) afirma que os profissionais de saúde que atuam no PSF devem estar preparados para o exercício de um novo processo de trabalho marcado por "uma prática ética, humana, cuidadosa, vinculada ao exercício da cidadania, baseada na compreensão de que as condições de vida determinam os processos de saúde/doença dos indivíduos/família/comunidades" (SOUSA 2002, p. 106). 


\subsection{COLETA DE DADOS}

Os dados foram coletados através de entrevistas semi-estruturadas divididas em dois momentos:

Momento I: pediu-se aos sujeitos a narração de uma situação na qual considerassem que tinham se defrontado com um problema ético, indicando a solução dada. Em seguida, solicitou-se ao entrevistado que listasse os problemas éticos na situação, segundo sua opinião. As perguntas norteadoras da entrevista neste momento foram:

a) Conte-me um caso que seja um problema ético com o qual você tenha se deparado nas suas atividades no PSF.

b) Se você tivesse que listar quais problemas éticos você vê nesta situação, como você listaria?

Momento II: apresentou-se a cada entrevistado situações hipotéticas contendo problemas éticos. Após a leitura dos casos, solicitou-se que recomendassem um curso de ação para solucionar o caso e justificassem sua indicação. Nas primeiras entrevistas realizadas ( 4 enfermeiros e 3 médicos) propôs-se somente um caso, entretanto, percebeu-se pouca variação nos argumentos apresentados. Por esta razão, nas subseqüentes, além do caso que vinha sendo usado desde o início, acrescentou-se outros dois seqüencialmente alternados a cada entrevista. Assim, os casos propostos foram très:

a) PERTURBANDO A ROTINA: O senhor $\mathrm{C}$, hipertenso e diabético, freqüentemente faz demandas que dificultam as atividades $\mathrm{e}$ perturbam a rotina da unidade de saúde. $O$ médico e a enfermeira da equipe na qual ele é cadastrado tentam assisti-lo da melhor maneira possivel, mas a cada dia sentem-se mais tentados a deixar de investir seus esforços. 
b) PRESERVANDO A CONFIDENCIALIDADE: $O$ senhor $M$ tem sífilis. Ele não quer contar o que tem para sua esposa, mas quer protegê-la da doença. Enquanto está em tratamento, pede à equipe que faça o exame em sua esposa sem que ela saiba.

c) ATENDENDO ADOLESCENTES: B, 15 anos de idade, procura a equipe de saúde da familia na qual está cadastrada e conta que recentemente apaixonou-se por um rapaz de 16 anos. Seus pais acham que ela é muito jovem e a proibem de namorar. A jovem diz que ainda não tem vida sexual ativa, mas pede uma prescrição de anticoncepcional oral. Também pede à equipe que nada seja contado aos seus pais.

O caso 'Perturbando a Rotina' foi comum a todos os entrevistados e os demais foram alternados. Após cada situação, seguiam-se as perguntas: ' $O$ que você recomendaria para os profissionais envolvidos neste caso?' e 'Por quê?'.

Os depoimentos foram gravados em fita magnética e transcritos. Apenas um dos entrevistados (médico 5) não autorizou a gravação, assim, para este, somente a resposta dada no momento I foi considerada na análise, pois foi possível transcrever de memória o caso relatado e na ocasião da entrevista tomar nota dos problemas listados.

O periodo de coleta teve lugar entre os meses de agosto de 2001 e fevereiro de 2002.

Para delimitar o que vem a ser um problema ético, adotou-se o entendimento de Sugarman (2000). Para este autor, por problema ético compreendem-se os aspectos, as questões ou as implicações éticas de ocorrências comuns na prática da atenção à saúde nas unidades básicas, não configurando, necessariamente, um 
dilema $^{4}$ (SUGARMAN 2000, p.xiv).

Vale notar que, com esse entendimento, não se fez a opção por excluir os dilemas, apenas pretendeu-se deixar claro que os casos narrados não obrigatoriamente deveriam se referir a situações dilemáticas. Se aparecessem, essas situações seriam tratadas juntamente com os problemas, sem preocupação em diferenciá-las.

Por ser esta uma pesquisa de cunho qualitativo, o critério de representatividade da amostra para o encerramento da coleta de dados não foi o numérico, mas a variabilidade que permitiu abranger a totalidade do problema investigado em suas múltiplas dimensões, ou seja, o da saturação do discurso.

\subsection{REFERENCIAL TEÓRICO}

Dentre as diferentes formas de sistematizar e tratar a análise em bioética, mencionadas na introdução deste trabalho, quatro delas foram selecionadas para compor o referencial de análise dos dados empíricos: o principialismo, a casuística, o das virtudes e o do cuidado. A estes, acrescentou-se o enfoque designado por "ética profissional", referindo-se ao fato, não raro, dos profissionais de saúde entenderem por agir ético na profissão a mera observância do código deontológico aprovado pelo conselho de pares fiscalizador do exercício de cada profissão. Estes referenciais encontram-se descritos no capítulo 4.

\footnotetext{
${ }^{4}$ Por dilema compreende-se "sistema de duas proposições contraditórias, entre as quais se é colocado na obrigação de escolher" ou ainda "(....) oposição mútua entre duas teses filosóficas tais que a aceitação ou o repúdio de uma, com os seus corolários, leva à negação ou à afirmação da outra sem que nenhuma das duas possa ser refutada com a ajuda dos princípios professados pelos dois partidos" (LALANDE 1999, p. 260).
} 


\subsection{ORGANIZAÇÃO DOS DADOS}

Para o momento I da pesquisa optou-se pela análise categorial temática, que é uma das técnicas da análise de conteúdo, proposta por Bardin (1977).

A análise de conteúdo é um conjunto de técnicas de análise das comunicações visando obter, por procedimentos sistemáticos e objetivos de descrição do conteúdo das mensagens, indicadores, quantitativos ou não, que permitam a inferência de conhecimentos relativos às condições de produção/recepção destas mensagens (BARDIN 1977).

O tratamento descritivo constitui um primeiro momento do procedimento, não sendo exclusivo e nem exaustivo da análise de conteúdo. $O$ interesse não se resume à descrição dos conteúdos, mas naquilo que podem ensinar após serem organizados e tratados, isto é, codificados. Como assinala Bardin (1977), a intenção da análise de conteúdo é alcançar através de indicadores, quantitativos ou não, a inferência de conhecimentos relativos às condições de produção ou eventualmente de recepção, ou seja, a análise de conteúdo não visa o estudo da língua ou da linguagem, mas a determinação das condições de produção dos textos, que conformam seu objeto. Portanto, o fundamento da especificidade da análise de conteúdo reside na articulação da superfície dos textos, descrita e analisada e dos fatores que determinam as características encontradas.

Os procedimentos básicos da análise de conteúdo incluem a pré-análise, a descrição analítica e a interpretação inferencial. A pré-análise é a fase de organização do material em que se especifica o campo no qual o pesquisador deve fixar sua atenção. Na fase da descrição analítica, o material empírico recebe tratamento, incluindo a codificação, a classificação e a categorização. Já na interpretação inferencial configura-se o momento do estabelecimento das relações entre os achados do material empírico e a realidade social, chegando, se possivel, a proposituras de transformação. Para isto, não basta reter-se ao conteúdo manifesto dos textos, mas 
deve-se desvendar o conteúdo latente, pois sendo esse dinâmico, estrutural e histórico é o que possibilita a identificação de ideologias, tendências etc. (TRIVIÑOS 1995).

Fazer uma análise temática requer descobrir os "núcleos de sentido" que compõem a comunicação e cuja freqüência, nas abordagens quantitativas, ou presença e ausência, nas qualitativas, pode ter um significado para o objeto analítico escolhido. $\mathrm{O}$ tema, como unidade de registro, corresponde a uma regra de recorte do sentido e não da forma da comunicação. Por unidade de registro, entende-se a unidade de significação a codificar, ou seja, o segmento de conteúdo a ser considerado como unidade de base a ser categorizada. A noção de tema em análise de conteúdo é uma afirmação sobre um assunto, uma frase, um resumo, é a unidade de significação que se liberta naturalmente de um texto quando analisado à luz de certos critérios relativos à teoria que serve de guia para a leitura.

Além da unidade de registro, convém delimitar a unidade de contexto, que serve de unidade de compreensão para codificar a primeira. Corresponde ao segmento da mensagem, cujas dimensões, superiores à unidade de registro, possibilita compreender a significação exata dessa. No caso do tema será um parágrafo que o contenha.

As motivações de opiniões, de atitudes, de valores, de crenças, de tendências, dentre outras, alẻm de respostas a questões abertas, a entrevistas não diretivas ou mais estruturadas, registros de reuniões de grupos, comunicações de massa etc. são freqüentemente analisados por tema.

Assim, considerando-se o objeto do presente estudo, a ética na atenção à saúde, e a técnica utilizada para a coleta de dados, entrevistas semi-estruturadas, pareceu-nos adequada a análise temática, dentro da proposição da análise de conteúdo. Como unidade de registro tomaram-se os próprios problemas identificados e listados pelos enfermeiros e médicos durante as entrevistas e como unidade de contexto os trechos do discurso que os continham. 
A transcrição de cada discurso foi lida para a identificação dos problemas apontados pelo profissional entrevistado. O conjunto dos problemas listados passou a configurar uma grade temática de análise que serviu para a leitura transversal dos depoimentos, ou seja, cada relato foi relido visando recortá-lo em torno de cada tema-objeto apontado.

Embora sabendo que o agrupamento das mensagens analisadas em rubricas ou classes, que são as categorias, não constitui etapa obrigatória da análise de conteúdo, optou-se, no presente estudo, por se observar esse procedimento para agrupar os problemas identificados, pois se entende que a condensação proporcionada pela categorização possibilita simplificar os dados brutos, facilitando sua interpretação. A reunião de um grupo de elementos sob um título genérico, que compõe a categorização, toma por base as características comuns destes elementos. $\mathrm{Na}$ análise de conteúdo, o conceito de categoria é usado de forma instrumental (MNAYO 1996b).

No momento II, também utilizou-se a análise de conteúdo proposta por Bardin (1977). Porém, empregou-se um processo inverso de categorização, ou seja, as categorias foram fornecidas previamente e os elementos encontrados nos discursos distribuídos entre elas. Este é o chamado "procedimento por caixas" (BARDIN 1977, p. 119).

A opção por esta inversão foi motivada pelo fato dos enfoques selecionados para referenciarem teoricamente a análise dos dados serem as categorias que se desejou discutir na análise. Assim, os discursos foram vasculhados na busca de elementos componentes destes distintos enfoques descritos no referencial teórico.

Os elementos procurados nos discursos emergiram do referencial teórico e estão apresentados no quadro a seguir: 


\section{QUADRO 3: ELEMENTOS COMPONENTES DOS ENFOQUES}

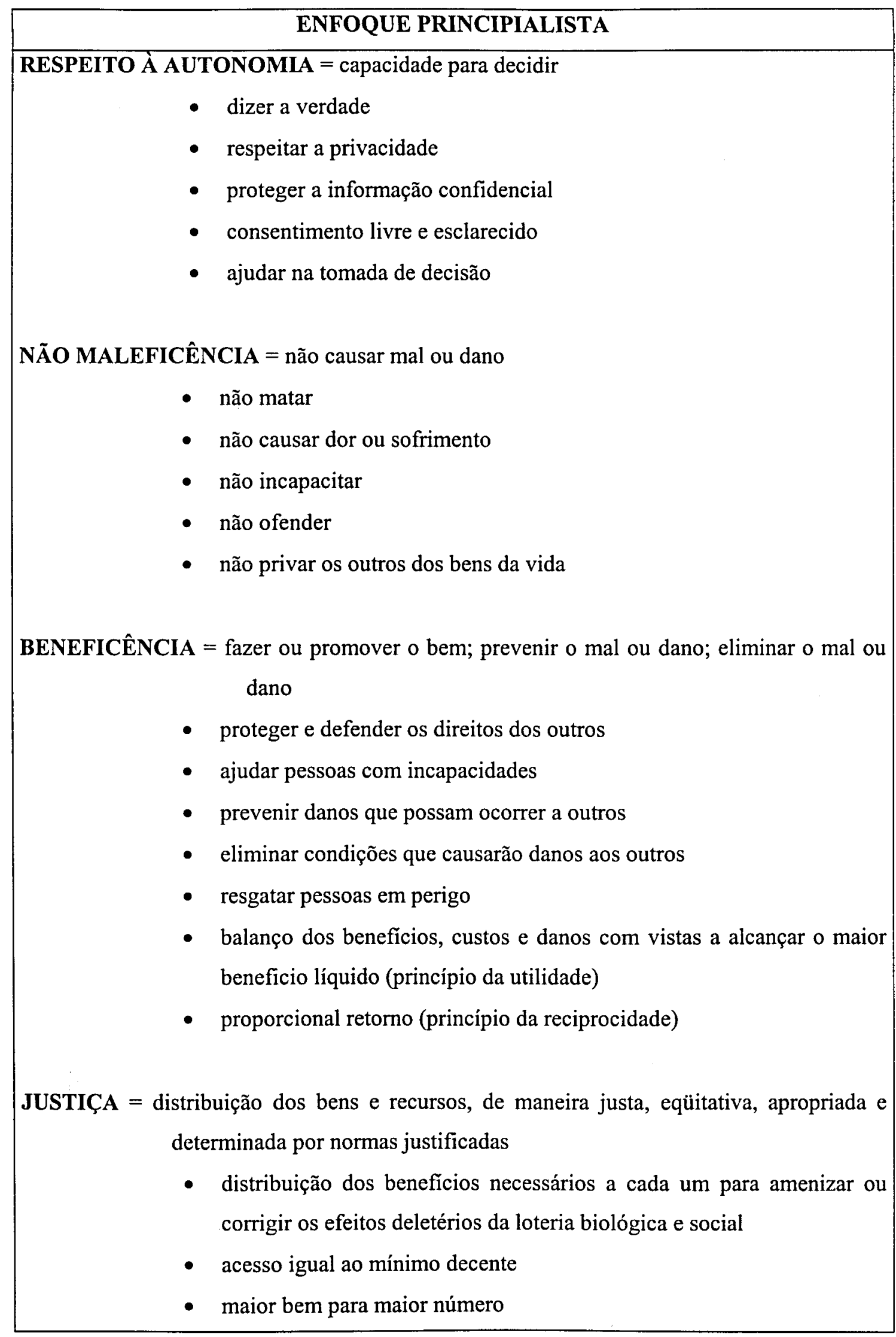




\begin{tabular}{|c|}
\hline ENFOQUE DAS VIRTUDES \\
\hline $\begin{array}{l}\text { - percepção da atenção à saúde como prática com bens internos } \\
\text { - honestidade na relação com outros partícipes da prática } \\
\text { - confiança nos demais partícipes da prática } \\
\text { - justiça = tratamento uniforme e impessoal de acordo com o mérito por } \\
\text { louvor ou castigo } \\
\text { - coragem = expor seus próprios interesses ao risco de danos ou perigos }\end{array}$ \\
\hline ENFOQUE DO CUIDADO \\
\hline $\begin{array}{l}\text { - reconhecimento da importância do vínculo mútuo } \\
\text { - fortalecimento das relações de vínculo } \\
\text { - não rompimento das relações de vínculo } \\
\text { - felicidade de todos } \\
\text { - não magoar ninguém } \\
\text { - busca da solução não violenta dos conflitos por meio da comunicação }\end{array}$ \\
\hline ENFOQUE DA ÉTICA PROFISSIONAL \\
\hline $\begin{array}{l}\text { - acatamento do código deontológico como o meio para resolver } \\
\text { problemas eticos } \\
\text { - temor à sanções e penalidades } \\
\text { - recurso às comissões de ética de enfermagem e medição para resolver } \\
\text { os problemas }\end{array}$ \\
\hline ENFOQUE DA CASUÍSTICA \\
\hline $\begin{array}{l}\text { - equacionamento por paradigma e analogia } \\
\text { - apelo às máximas } \\
\text { - análise das circunstâncias } \\
\text { - probabilidade }\end{array}$ \\
\hline
\end{tabular}

As transcrições dos discursos foram lidas transversalmente com base nessa grade de elementos a fim de se identificar sua presença e não a freqüência. Isto porque, segundo Bardin (1977), uma das características da análise qualitativa é o fato da inferência, que é sempre realizada, fundar-se na presença do índice (tema, palavra, 
personagem etc.) e não na frequêencia de sua aparição em cada comunicação individual. Assim, a simples presença do elemento no discurso permitiu inferir que o entrevistado estava lançando mão do enfoque em questão para resolver o caso hipotético proposto.

Antes desta leitura transversal, todos os discursos passaram por uma leitura flutuante com vistas a identificar como os entrevistados elaboravam o problema em questão nos cenários hipotéticos. Isto porque, segundo Gilligan (1998), as diferentes imagens dos relacionamentos redundam em distintos modos de compreender a moralidade e de pensar acerca de conflito e escolha, dependendo, então, o juízo ético do modo como o problema é formulado. Assim, pode-se depreender que os diversos modos de compreender a moralidade, expressos nos enfoques escolhidos no referencial teórico, implicam em diferentes modos de pensar acerca de conflito e escolha, ou seja, envolvem distintas maneiras de formular e, conseqüentemente, conduzir a solução do problema ético. Fazer emergir dos discursos esta elaboração do problema pode colaborar para a compreensão da argumentação presente na tomada de decisão.

Da mesma maneira, o referencial teórico permitiu delinear diferentes maneiras de se formular os problemas em cada um dos enfoques: 


\section{QUADRO 4: FORMULAÇÃO DOS PROBLEMAS ÉTICOS}

\begin{tabular}{|l|l|}
\hline $\begin{array}{l}\text { ENFOQUE } \\
\text { PRINCIPIALISTA }\end{array}$ & $\begin{array}{l}\text { Confronto de divergentes obrigações morais decorrentes } \\
\text { dos princípios. }\end{array}$ \\
\hline $\begin{array}{l}\text { ENFOQUE DAS } \\
\text { VIRTUDES }\end{array}$ & Ameaça à realização do bem interno de uma prática. \\
\hline ENFOQUE DO & $\begin{array}{l}\text { Ruptura na rede de responsabilidades e relacionamentos } \\
\text { mútuos. }\end{array}$ \\
\hline $\begin{array}{l}\text { ENFOQUE DA ÉTICA } \\
\text { PROFISSIONAL }\end{array}$ & $\begin{array}{l}\text { Infração ao código deontológico e às demais legislações } \\
\text { que regulamentam o exercício profissional. }\end{array}$ \\
\hline $\begin{array}{l}\text { ENFOQUE DA } \\
\text { CASUÍSTICA }\end{array}$ & $\begin{array}{l}\text { Arranjo do caso por paradigma e analogia em um } \\
\text { conjunto de situações do mesmo tipo. }\end{array}$ \\
\hline
\end{tabular}

Quanto a este ponto, vale notar que Beauchamp e Childress (2001) também apontam para a possibilidade de variação na formulação dos problemas éticos ao distinguirem as diversas formas de cada teoria moral, que exploram em sua obra, explicar e abordar um mesmo caso clínico apresentado.

A proposta inicial deste estudo, como definida no projeto, previu a utilização, no momento II, dos enfoques principialista, das virtudes, do cuidado e da ética profissional como referencial para a análise dos dados. Entretanto, a leitura flutuante dos discursos transcritos mostrou a necessidade de se incluir o da casuística.

Ainda, quanto à casuística, vale assinalar que o projeto da presente pesquisa previu o emprego deste referencial para a organização dos dados coletados no momento I das entrevistas, seguindo o método proposto por Jonsen e col. (1999), que enfoca situações envolvendo questões do âmbito da ética clínica, ou seja, "problemas éticos encontrados na tomada de decisões perante os doentes" (Jonsen e col. 1999, p. 4). Entretanto, após a revisão dos 34 depoimentos, verificou-se que 13 narrativas (7 dos enfermeiros e 6 dos médicos) traziam tal tipo de situação, sendo, portanto, passiveis à aplicação da metodologia da casuística. 
O reduzido número de casos que restou para exame, apenas 13 dos 34 coletados, não foi a única limitação encontrada. Ao se proceder a uma classificação dos problemas éticos encontrados nestes depoimentos, segundo os tópicos da casuística, e compará-la com as listagens resultantes da aplicação da análise de conteúdo ao universo dos casos coletados, verificou-se, obviamente, que o leque de problemas restringia-se às fronteiras das questões clínicas, não possibilitando evidenciar que a percepção dos enfermeiros e médicos entrevistados ultrapassava estes limites. Assim, optou-se por modificar a proposição inicial e seguir os procedimentos que foram descritos nesta sessão. 


\section{REFERENCIAL TEÓRICO}

Ao iniciar o presente capítulo, é mister tecer esclarecimentos a respeito de como os referenciais teóricos escolhidos para a análise dos dados empiricos dos dois momentos que compõem este estudo são tratados. Ao definir este estudo como uma pesquisa empírica e uma abordagem não normativa e descritiva da ética, seu propósito não está na busca da validez interna dos diversos referenciais, e sim em explorar como estes se apresentam na prática cotidiana e na linguagem comum (não filosófica) dos profissionais de saúde. Desta forma, as explanações não tomam em conta as diversas críticas dirigidas a cada um dos referencias. Com isto, em hipótese alguma, está se desconhecendo que estas existem e que o debate entre as diferentes correntes teóricas representa um importante tópico da produção em bioética, sendo objeto de artigos e obras, como A Matter of Principles? ferment in U.S. Bioethics, editada por Edwin R. DuBose, Ron Hamel e Laurence J. O'Connell em 1994; After MacIntyre: critical perspectives on the Work of Alasdair MacIntyre, organizada por John Horton e Susan Mendus em 1994; Feminism and Bioethics: Beyond the reproduction, coordenada por Susan M. Wolf em 1996; Philosophical Perspectives on Bioethics, na qual L. Wayne Sumner e Joseph Boyle reúnem ensaios apresentados durante seminários promovidos em 1993 e 1994 pelo Centro de Bioética da Universidade de Toronto; O que é Bioética, de autoria de Débora Diniz e Dirce Guilhem, lançada em 2002, dentre outras. Também no Congresso Mundial de Bioética de 2002, esse tema foi tratado em algumas mesas, por exemplo, The four principles approach to health care ethics - hegemony?, com Raanan Gillon; Critical Analyis of Principialism, com Søren Holm; Hard Bioethics: a peripherial perspective of intervention ethics, com Volnei Garrafa e Bioethics in the perspective of liberation theology, com Marcio Fabri dos Anjos.

Mediante estas ponderações, a opção nesse estudo foi utilizar como recurso bibliográfico para a explanação dos diversos referenciais teóricos as obras consideradas marcos iniciais de cada enfoque, dando preferência, quando possível, a última edição, por se acreditar que os autores poderiam ter nela incorporado 
respostas à possiveis críticas tecidas à sua proposta, não ficando, assim, este estudo tão ao largo da polêmica entre as diversas concepções teóricas na bioética.

Desta maneira, para a casuística, apresenta-se um panorama do livro The abuse of casuistry: a history of moral reasoning, escrito por Albert $\mathrm{R}$. Jonsen $\mathrm{e}$ Stephen Toulmin em 1988; para a o enfoque principialista, toma-se a quinta edição, lançada em 2001, da obra de Tom Beauchamp e James Childress, Principles of biomedical ethics; para o enfoque das virtudes, usa-se a segunda edição de After Virtue, de Alasdair MacIntyre, escrita em 1984 e In a Different Voice: psychological theory and women's development, de autoria de Carol Gilligan, numa reimpressão ampliada com a introdução de um novo prefácio de 1993, serve de base para o enfoque do cuidado. Para o enfoque da ética profissional, não se adota uma única obra como fonte, utilizando-se os códigos de ética profissional das duas categorias dos sujeitos dessa pesquisa (enfermagem e medicina) e textos que discutem os fundamentos, o ensino, a evolução e a prática da deontologia nas profissões.

Ainda, deve ser acrescentado que, como a proposta inicial desta pesquisa incluía explorar a casuística também como um método de tomada de decisão em ética no cenário da atenção básica, organizando e analisando através dele os casos relatados no momento I, apresentam-se alguns pontos da quarta edição da obra Clinical Ethics de Albert R. Jonsen, Mark Siegler e William J. Winslade, utilizandose uma tradução portuguesa do original em inglês.

Outro ponto que precisa ser mencionado é que ao se optar pelo After Virtue como recurso bibliográfico para o enfoque das virtudes, não se desconhece que há obras que tratam de aproximar este referencial da prática da saúde, como For the patient's good, de Edmund Pellegrino e David Thomasma e In becoming a good doctor: the place of virtue and character in medical ethics, de James Drane. Mas, como ponderado anteriormente, buscou-se tomar por referência a obra tida como marco inicial para a inclusão do enfoque no escopo da bioética e atribui-se, segundo alguns autores, ao After Virtue o estímulo para o renovado interesse na natureza e significado da ética das virtudes, tendo os trabalhos mencionados dialogado com a 
proposta de MacIntyre (HAUERWAS 1995; PESSINI e BARCHIFONTAINE 2002).

\subsection{O ENFOQUE PRINCIPIALISTA: A ÊNFASE NOS PRINCÍPIOS E NOS ATOS}

O modelo principialista é a forma de análise mais difundida na bioética, chegando a confundir-se com ela. Seus protagonistas são Tom Beauchamp e James Childress que propõem quatro princípios como orientadores referenciais para a análise dos problemas éticos: o respeito à autonomia, a não maleficência, a beneficência e a justiça. Sua obra Principles of Biomedical Ethics teve a primeira edição em língua inglesa lançada em fins de 1978 e a quinta em 2001, sendo esta (BEAUCHAMP e CHILDRESS 2001) a utilizada para a presente apresentação deste referencial teórico.

\subsubsection{PARA ENTENDER O PRINCIPIALISMO}

\subsubsection{1 ÉTICA, MORALIDADE E MORAL COMUM}

Para Tom Beauchamp e James Childress, ética é um termo genérico que abarca vários modos de entender e examinar a vida moral, distinguindo-se em abordagens normativas e não normativas (metaética e ética descritiva).

Moralidade refere-se às normas de conduta humana certa e errada compartilhadas e que formam um estável, embora incompleto, consenso social. Conforma, uma instituição social anterior às reflexões encontradas na ética filosófica ou teológica, abrangendo diversos padrões de conduta, como os princípios morais, as regras, os direitos e as virtudes. 
Os autores ponderam que todos crescem com um entendimento básico da instituição moralidade, sendo suas normas prontamente entendidas, ou seja, todas as pessoas idôneas ${ }^{6}$ acerca de como viver uma vida moral compreendem as dimensões nucleares da moralidade. Sabem que não mentir; não roubar; manter as promessas; respeitar os direitos dos outros; não matar e não causar danos às pessoas inocentes são basilares e que violar estas normas, sem uma razão moralmente boa e suficiente, é imoral e deve levar a sentimentos de remorso. A este conjunto de normas compartidas pelas pessoas moralmente idôneass, os autores denominam moral comum. A moral comum, então, contém as normas morais que vinculam todas as pessoas em todos os lugares, não havendo outra norma mais fundamental na vida moral. Exemplificam, afirmando que em anos mais recentes, este núcleo no discurso público vem sendo representado pelos direitos humanos.

Segundo os autores, a moralidade é mais que a moral comum e as duas não podem ser confundidas. A primeira pode incluir, dentre outros, os ideais morais aceitos voluntariamente por indivíduos ou grupos, as normas que vinculam apenas os membros de comunidades morais específicas e as virtudes extraordinárias. Por outro lado, a moral comum compreende somente as normas que todas as pessoas moralmente idôneas aceitam como sendo portadoras de autoridade.

Para Beauchamp e Childress, considerando-se uma comunidade específica, a moralidade reflete diferenças culturais significantes, mas os autores consideram isto como um fato institucional da própria moralidade com seus preceitos fundamentais, os quais tornam possível os juizos inter-temporais e trans-culturais que levam a ponderar que nem todas as práticas dos distintos grupos culturais são aceitáveis do ponto de vista ético. A escravidão, a discriminação de gênero e racial e outras práticas inaceitáveis têm aparecido através da história, mas o fato de sua existência não as torna moralmente aceitáveis, ainda que uma sociedade em particular as vejam como tal.

\footnotetext{
${ }^{6}$ Do inglês, serious persons (BEAUCHAMP e CHILDRESS 2001, p. 3).
} 
Assim, ponderam que o uso da moral comum como marco inicial do equacionamento ético não precisa necessariamente levar a conclusões costumeiramente aceitas. Uma função das normas gerais na moral comum é propiciar base para a avaliação e o criticismo dos grupos ou das comunidades, cujos pontos de vista morais usuais são, em algum aspecto, defectivos. A reflexão crítica pode, em última instância, vindicar juizos que de início não são amplamente compartilhados. Em resumo, para os autores, a moral comum é elemento pré-teórico que transcende costumes e atitudes locais, estando asseguradas as conclusões críticas acerca destes costumes e atitudes ao se manter a fidelidade à própria moral comum.

Beauchamp e Childress entendem que a moral comum goza de autoridade moral quanto à conduta de todas as pessoas, sendo ela a base para as teses normativas e teorias éticas elementares que desenvolvem no livro. Com isto, desejam tornar claro que as normas que propõem não estão baseadas em uma teoria ou doutrina filosófica ou teológica em particular. Por outro lado, salientam que ao tomar a moral comum como ponto de partida não esperam poder validamente defender a autoridade para tudo que construíram. Reconhecem que seria absurdo supor que todas as pessoas, de fato, aceitam todas as normas da moral comum. Muitos amorais, imorais ou pessoas seletivamente morais, como classificam, não se preocupam e tampouco se identificam com estas ou outras demandas morais. Entretanto, os autores acreditam que todas as pessoas idôneas, de todas as culturas, aceitam as demandas da moral comum.

\subsubsection{PRINCÍPIOS, REGRAS E OUTRAS CONSIDERAÇÕES MORAIS}

$\mathrm{Na}$ moral comum, segundo os autores, encontram-se princípios que são básicos para a ética biomédica. Um conjunto de princípios configura uma estrutura analítica expressando os valores gerais que marcam as regras na moral comum. Estes principios podem funcionar como guias de conduta para a ética profissional. Em sua obra, defendem quatro agrupamentos deste tipo de princípios que consideram centrais para a ética biomédica, após examinarem juizos éticos respeitados e a 
maneira pela qual crenças morais ganham consistência ${ }^{7}$. Estes incluem o respeito à autonomia (uma norma de respeito à capacidade de tomar decisão das pessoas autônomas); a não maleficência (uma norma de evitar causar danos); a beneficência (um grupo de normas que visa prover beneficios e ponderar beneficios, riscos e custos) e a justiça (um grupo de normas para a distribuição justa de beneficios, riscos e custos). A escolha dos princípios e a especificação de seu conteúdo decorrem da tentativa dos autores juntarem a moral comum e as tradições médicas em um único e coeso pacote.

Embora os autores acreditem que os princípios provejam as normas mais gerais e abrangentes, o modelo por eles proposto abarca vários tipos de normas morais, incluindo, além dos princípios, as regras, os direitos, as virtudes e os ideais morais. Contudo, como destacam, operam com uma pequena distinção entre regras e princípios, tendo estes como normas gerais que guiam ações. A diferença reside no fato das regras serem mais específicas em conteúdo e mais restritas no escopo do que os principios. Desta forma, os princípios são normas gerais que permitem, em muitos casos, um espaço considerável para o juízo, não funcionando como um guia preciso de ação que informa como agir em cada circunstância, ao contrário do que fazem as regras mais detalhadas e os juizos.

Por esta razão, defendem diversos tipos de regras que especificam os princípios e propiciam uma diretriz de ação mais especifica. Estas regras podem ser substantivas, de autoridade e procedimentais. As regras substantivas são as que delineiam padrões substantivos ou critérios para a tomada de decisões, como regras de dizer a verdade, de confidencialidade, privacidade, descontinuação de tratamento, suicídio assistido pelo médico, consentimento informado e racionamento de cuidados de saúde. As regras de autoridade dizem respeito a quem pode e/ou deveria desempenhar as ações de tomada de decisão. Entre as regras de autoridade e as

\footnotetext{
7 As palavras inglesas coherency, coherence correspondem, preferencialmente, à coesão ou consistência. Coesào é a "caracteristica de um pensamento, de uma exposição, em que todas as partes estão solidamente unidas entre si" (LALANDE, 1999 p. 166). Consistência é a caracteristica de um pensamento que não é fugaz, inefável ou contraditório; firmeza lógica de uma doutrina ou de um argumento; característica daquilo que é sólido e não depende do arbitrio ou de circunstâncias acidentais, mas possui qualidades de permanência e objetividade (LALANDE, p. 199).
} 
substantivas há uma interação. As regras procedimentais estabelecem procedimentos a serem seguidos e as elas se recorre, com freqüência, quando se esgotam as regras substantivas e as de autoridade mostram-se incompletas ou inconclusivas.

O modelo de princípios e regras, adotado pelos autores, não menciona o direito das pessoas, o caráter e as virtudes dos agentes que desempenham ações e as emoções morais. Isto porque consideram que estes aspectos da vida moral merecem atenção em uma teoria mais ampla, embora reconheçam que os direitos, as virtudes e as respostas emocionais sejam tão importantes quanto os princípios e as regras para uma visão abrangente da vida moral.

\subsubsection{A NATUREZA PRIMA FACIE DAS NORMAS MORAIS}

Para discutir esta questão, Beauchamp e Childress tomam por base o pensamento de W. D. Ross, que distingue as obrigações prima facie e as obrigações de fato ou reais. Esta distinção é tida pelos autores como essencial para sua análise.

Uma obrigação prima facie deve ser cumprida a menos que conflite, em determinadas ocasiões, com uma obrigação de igual ou mais força, ou seja, é uma obrigação moral vinculante a menos que, em uma circunstância em particular, uma outra rival seja sobreexcedente ${ }^{8}$. Alguns atos não são prima facie errados ou certos, porque duas ou mais normas podem conflitar em certas situações e, nestas condições, os agentes devem determinar o que fazer, encontrando uma obrigação real ou sobreexcedente pelo confronto das obrigações prima facie. Isto é, devem localizar "o maior balanço" (p.15) do certo sobre o errado, através do exame dos pesos das obrigações prima facie rivais.

Os autores entendem que nenhuma teoria ou código de ética profissional apresenta um sistema de regras livre de conflitos e/ou exceções, contudo não vêem este fato como causa de cepticismo ou alarme. Por isto, consideram que a distinção proposta por Ross se adapta muito bem à experiência dos agentes morais, provendo

\footnotetext{
${ }^{8}$ Dos termos, em inglês, override e outweight (BEAUCHAMP e CHILDRESS 2001, p. 14)
} 
as categorias indispensáveis para a ética biomédica, uma vez que não são raras as situações nas quais se deve escolher entre valores plurais e conflitantes, a partir da ponderação de várias considerações.

A exemplo de Ross, Beauchamp e Childress constroem seus princípios como prima facie. Entendem que a necessidade de ponderar princípios prima facie nos casos de conflito deixa espaço para o compromisso, a mediação e a negociação e sua especificação permite o crescimento moral.

\subsubsection{ESPECIFICANDO E PONDERANDO PRINCÍPIOS E REGRAS}

Os quatro grupos de principios propostos por Beauchamp e Childress não constituem uma teoria moral geral, mas proporcionam apenas uma estrutura para identificar e refletir acerca dos problemas éticos. Os autores alertam que esta estrutura é frágil, pois princípios prima facie não gozam de conteúdo suficiente para encaminhar as distintas perspectivas de muitas circunstâncias. Assim, é fundamental especificar e ponderar estes princípios abstratos.

Especificar é reduzir a indeterminação das normas abstratas, provendo-as de conteúdo para guiar uma ação. Por exemplo, sem especificação, "não causar danos" configura um ponto inicial pobre para se pensar as questões relativas a problemas como o suicídio assistido e a eutanásia, sendo insuficiente para nortear adequadamente uma ação quando as normas entrarem em conflito. Assim, os problemas éticos da prática cotidiana requerem que as normas gerais sejam especificadas para os contextos particulares ou um leque de casos.

A fim de que os princípios possam ter conteúdo suficiente para a aplicação prática, alertam que é necessário especificar seu conteúdo com vistas a indicar o motivo e a forma como os casos podem ser regidos pelos princípios, pois é a progressiva especificação que pode dar conta da variedade de problemas que surgem, gradualmente reduzindo os dilemas e conflitos impassíveis de solução devido à insuficiência de conteúdo dos princípios abstratos. Prover os princípios com 
substância por meio da especificação é primordial para a tomada de decisão em ética clínica e para desenvolver as regras institucionais e as políticas públicas. Todas as normas morais são, em tese, sujeitas a tal especificação e precisam deste conteúdo adicional porque a complexidade do fenômeno moral usualmente ultrapassa a habilidade disponível para capturá-lo através das normas gerais.

Porém, este processo de especificar tem seus limites, isto é, por mais minuciosa que seja uma especificação, ela pode não conseguir eliminar por completo o conflito. Em casos problemáticos ou dilemáticos, distintas especificações rivais podem indicar diversas resoluções possiveis fazendo a situação retornar ao ponto inicial que determinou a necessidade de especificar as normas. $E$, ainda que a especificação elimine um conflito contingente, esta pode ser arbitrária, perder a imparcialidade ou falhar por outras razões. Além do mais, o excesso de confiança na especificação pode levar a uma certeza dogmática. Assim, a fim de escapar da abstração, os princípios requerem uma especificação cuidadosa, mas não demasiada, sob risco de tornarem-se rígidos e insensiveis às circunstâncias.

Tanto quanto especificar, os princípios e as regras requerem ponderação, pois estes processos tratam de dimensões distintas. A especificação possibilita 0 refinamento substantivo da extensão e do alcance das normas e regras, enquanto a ponderação delibera e julga acerca de seus pesos e forças relativas. Ponderar é especialmente importante para alcançar juízos em casos individuais e a especificação é particularmente útil no desenvolvimento de políticas. Ponderações justificadas possibilitam o provimento de boas razões para os atos e não, meramente, que um agente esteja intuitivamente satisfeito.

Em resposta à critica de que a ponderação é intuitiva e aberta, faltando-lhe um firme compromisso com os princípios, os autores listam algumas condições para reduzir a intuição e que devem ser atendidas a fim de se justificar a infração de uma norma prima facie em favor de outra:

- podem ser oferecidas melhores razões para se agir segundo a norma preponderante que será seguida, do que pela que será infringida; 
- o objetivo ético que justifica a infração deve ter uma perspectiva real de consecução;

- a infração torna-se necessária quando nenhuma outra ação eticamente preferivel pode substituí-la;

- a infração selecionada deve ser a menos danosa possível em comparação ao objetivo primário da ação;

- o agente deve procurar minimizar qualquer efeito negativo da infração;

- o agente deve atuar de maneira imparcial em relação a todas as partes afetadas, ou seja, sua decisão não deve ser influenciada por informações eticamente irrelevantes acerca de qualquer uma das partes envolvidas.

Embora algumas destas condições pareçam óbvias e não causem controvérsias, consideram que, freqüentemente, não são observadas na deliberação moral, mas se o fossem, as ações poderiam ser bem diferentes. Para Beauchamp e Childress, estas condições constituem obrigações morais e, juntamente com os apelos por uma consistência ética, ajudam a alcançar uma proteção razoável contra os juízos puramente intuitivos ou subjetivos.

\subsubsection{OS QUATRO PRINCÍPIOS DA ÉTICA BIOMÉDICA}

\subsubsection{RESPEITO À AUTONOMIA}

No escopo da autonomia, Beauchamp e Childress enfocam a tomada de decisão individual, tanto na atenção à saúde, como na pesquisa biomédica, especialmente o consentimento e a recusa informados. Alertam que o fato de começarem a discussão dos princípios da ética biomédica pelo respeito à autonomia não significa que este tem prioridade sobre os demais. Vêem como um equívoco as críticas usualmente feitas de que conferem primazia ao princípio do respeito à autonomia em relação a outras considerações morais. Assim, reafirmam que almejam construir uma concepção de respeito à autonomia que não é excessivamente individualista, negando a natureza social dos indivíduos e o impacto das escolhas e ações individuais sobre os outros, nem demasiadamente focada na razão, rejeitando 
as emoções e tampouco indevidamente legalista, destacando os direitos legais e desprezando as práticas sociais.

A palavra autonomia, derivada dos termos gregos autos (próprio) e nomos (regra, governo ou lei), originalmente referia-se ao autogoverno ou a autolegislação das cidades-estados independentes. Somente depois foi estendida aos indivíduos, adquirindo significados tão diversos como autogoverno, direitos de liberdade, privacidade, escolha individual, livre arbítrio, eleição do próprio comportamento e ser dono de si mesmo.

Algumas teorias de autonomia, como assinalam os autores, ao caracterizarem os traços de uma pessoa autônoma, incluem as habilidades gerais para o autogoverno, além do entendimento, eqüacionamento, deliberação e escolha independentes. Entretanto, por estar seu foco centrado na tomada de decisão, concentram-se, como eles próprios admitem, na escolha autônoma, mais do que na capacidade geral para o autogoverno.

Assim, autonomia pessoal consiste, ao menos, na autolegislação livre da interferência controladora dos outros e de limitações, como o inadequado entendimento impeditivo de uma escolha expressiva. O indivíduo autônomo age livremente segundo seu plano auto-escolhido, de maneira análoga à forma que um governo independente controla seus territórios e estabelece suas politicas. Já os que têm autonomia reduzida são, em certa medida, controlados pelos outros ou incapazes de deliberar ou de agir com base em seus desejos e planos.

Segundo os autores, todas as teorias sobre autonomia concordam que há duas condições que lhe são essenciais: a liberdade - entendida como independência de influências controladoras - e a competência - compreendida como a capacidade para ação intencional. Entretanto, quando a questão é o significado destas condições e a necessidade de outras adicionais, os desacordos se instalam. 
A presença ou ausência de autonomia é analisada em função dos condicionantes dos atos dos agentes envolvidos. Esta análise da ação autônoma tem por base decisores comuns que procedem de maneira intencionada, com compreensão e na ausência de influências controladoras que determinam a ação. A primeira destas três condições não permite gradação, os atos são ou não são intencionais. No entanto, o entendimento e a ausência de influências controladoras podem ser satisfeitos em maior ou menor extensão, o que indicará o grau de autonomia das ações. Para ambas as condições há um amplo continuum que vai desde a total ausência da autonomia até sua presença completa.

Nesta perspectiva, as decisões precisam ser substancialmente autônomas e não completamente autônomas, ou seja, para que um ato seja tido como autônomo é necessário somente um grau substancial de compreensão e de liberdade de constrangimentos e não um entendimento total e uma completa ausência de influências. A linha demarcatória entre o substancial e o insubstancial freqüentemente parece arbitrária. Contudo, os limiares para as decisões substancialmente autônomas podem ser fixados à luz de objetivos específicos.

Nos últimos anos, visões feministas têm revisado concepções individualistas ou atomísticas de autonomia com base nas idéias de "autonomia relacional" que defendem a conviç̧ão que "as pessoas são socialmente inseridas e que as identidades dos agentes são formadas dentro do contexto social de relacionamentos e modeladas por uma complexa intersecção de determinantes sociais, como raça, classe, gênero e etnicidade". Mantêm que "a opressiva socialização e os opressivos relacionamentos sociais" podem prejudicar a autonomia através da fomentação de desejos, crenças, emoções e atitudes nos agentes; da frustração do desenvolvimento de capacidades e competências essenciais para a autonomia e de várias restrições e limitações no leque de alternativas de ação. Beauchamp e Childress afirmam apoiar os apelos pela superação da "socialização e relacionamentos opressivos" e ressaltam que estes chamam a atenção para a autonomia relacional, mas sem, com isto, rejeitar a autonomia em si (p. 61). 
Os autores registram que muitos lamentam o "triunfo da autonomia" (p. 61) na bioética norte-americana, salientando que este força os pacientes a fazerem escolhas a despeito de quererem receber informação sobre sua condição ou tomar suas próprias decisões. Reconhecem a existência de uma posição que parece afirmar um dever dos pacientes decidirem, entretanto esclarecem que eles não defendem tal visão, mas um princípio de respeito à autonomia com um correlativo direito e não um dever mandatório de escolher.

Assim, para os autores, a interpretação mais adequada do respeito à autonomia abarca o reconhecimento de uma obrigação fundamental de assegurar, da mesma forma, aos usuários dos serviços de saúde o direito de escolherem, aceitarem ou declinarem da informação. Tanto a informação e a escolha forçadas quanto a revelação evasiva são incongruentes com esta obrigação. Em outras palavras, consideram que os profissionais de saúde deveriam sempre indagar dos pacientes seus desejos de receber informação e tomar suas decisões, não assumindo que pelo fato de pertencer a uma determinada comunidade, este compartilha totalmente da visão de mundo e dos valores por ela propalados. O fundamental está no respeito às escolhas autônomas das pessoas em particular. Respeito à autonomia não constitui um mero ideal na atenção à saúde, mas uma obrigação profissional. E a escolha autônoma configura um direito e não um dever dos pacientes.

Respeitar uma pessoa como agente autônomo significa, no mínimo, acatar seu direito de ter opiniões próprias, de fazer suas escolhas e de agir segundo seus valores e crenças pessoais. Isto envolve uma ação respeitosa e não meramente uma atitude respeitosa, requerendo mais do que uma não interferência nos assuntos alheios $\mathrm{e}$ incluindo, especialmente em certos contextos, as obrigações de construir ou manter a capacidade dos outros para procederem às escolhas autônomas através da mitigação de medos e demais condições destrutivas ou rompedoras das decisões autônomas. Nesta perspectiva, o respeito abrange a aceitação dos direitos de tomada de decisão e a capacitação das pesşoas para agirem autonomamente, enquanto o desrespeito inclui atitudes e ações que ignoram, insultam ou aviltam os direitos de autonomia dos outros. 
O princípio do respeito à autonomia pode ser enunciado como uma obrigação negativa ou positiva. $\mathrm{Na}$ primeira condição, declaram que as ações autônomas não deveriam ser submetidas a influências controladoras dos outros. Na situação de uma obrigação positiva, impõe um trato respeitoso no fornecimento das informações e no estímulo à tomada de decisões autônomas, havendo, em alguns casos, o dever de aumentar as alternativas disponíveis. Muitas ações autônomas seriam impossíveis sem a cooperação material de terceiros com vistas a disponibilizar distintas opções. $O$ imperativo de tratar os outros como fim implica em assistir as pessoas na consecução de seus próprios objetivos e em estimular suas capacidades como agentes e não simplesmente que se evite tratá-las unicamente como meios para as metas de outros. Estas obrigações positivas de respeitar a autonomia emanam, em parte, das próprias obrigações fiduciárias especiais que os profissionais de saúde têm para com os pacientes e os pesquisadores para com os sujeitos.

Por abarcar obrigações positivas e negativas, o princípio do respeito à autonomia dá base para muitas regras morais mais específicas, como: dizer a verdade; respeitar a privacidade; proteger a informação confidencial; obter o consentimento antes de intervir e, quando solicitado, ajudar as pessoas a tomarem decisões importantes.

Tom Beauchamp e James Childress ressaltam que o respeito à autonomia configura um dever prima facie, podendo, em determinadas circunstâncias, ser sobrepujado por outras obrigações morais que o rivalizam, como no caso das escolhas autônomas dos indivíduos ameaçarem a saúde pública, poderem causar danos a terceiros ou demandarem indevidamente a utilização de recursos escassos. $\mathrm{Na}$ vigência destas condições, justifica-se a restrição do exercício da autonomia, a exemplo do que ocorre quando as pessoas não podem ser declaradas autônomas para tomar decisões, sejam as gerais ou mesmo as mais pontuais. Conferir ao princípio do respeito à autonomia prioridade em relação aos demais, além de lhe atribuir um peso desmedido para um sistema prima facie, despreza o fato de que a moral comum está 
igualmente enraizada nos outros três agrupamentos de principios que conformam a proposta dos autores.

Para os autores, o paradigma básico da autonomia na atenção à saúde, pesquisa, politica e outros contextos consiste em expressar o consentimento. A competência para tal é um quesito complexo, pois pacientes e sujeitos de pesquisa em potencial podem não ser competentes para emitir um consentimento ou uma recusa válidos. As indagações sobre competência focalizam-se na capacidade psicológica ou legal das pessoas para a adequada tomada de decisão, pois o fato de alguém ser competente para decidir está intimamente ligado ao grau de autonomia presente neste ato e à validade do consentimento ou da recusa decorrentes.

Desta forma, segundo eles, o conceito de competência para a tomada de decisão guarda vinculo estreito com o de autonomia. Os pacientes podem ser tidos como competentes para decidir quando apresentam capacidade de entender a informação material; de proceder ao juizo desta à luz de seus valores; de almejar um determinado resultado e de comunicar livremente seus desejos para os profissionais. Neste sentido, a lei, a medicina e, em certa extensão, a filosofia partilham uma correspondência das características da pessoa competente e das propriedades da pessoa autônoma. Assim, embora autonomia e competência distanciem-se no significado, com a primeira expressando autolegislação e a segunda a habilidade de desempenhar tarefas, aproximam-se na similaridade dos critérios para sua avaliação. Disto decorre que uma pessoa autônoma é necessariamente competente para tomar decisões e que os juízos acerca da competência de uma pessoa para autorizar ou recusar uma intervenção deveriam basear-se em sua capacidade de escolher autonomamente em circunstâncias particulares. 


\subsubsection{NÃO MALEFICÊNCIA}

O princípio da não maleficência afirma uma obrigação de não causar danos aos outros. Na ética médica, associa-se à máxima primum non nocere, que significa "acima de tudo (ou primeiro) não cause danos", sendo que no juramento hipocrático encontram-se expressas obrigações de não maleficência e beneficência: "Eu usarei tratamento para ajudar o doente de acordo com minha habilidade e julgamento, mas eu nunca o usarei para prejudicar ou causar dano a alguém" (p. 113).

Beauchamp e Childress reconhecem que alguns filósofos combinam a não maleficência e a beneficência em um único princípio, como William Frankena, que sob a égide do último, inclui quatro obrigações gerais ordenadas serialmente: não causar mal ou dano; prevenir o mal ou dano; eliminar o mal ou dano e fazer ou promover o bem. Entretanto, discordam desta junção e na distinção dos princípios que propõem, a primeira obrigação insere-se na não maleficência e as demais na beneficência, sendo dispensável hierarquizar as obrigações, pois esta necessidade decorre do fato de Frankena juntar as idéias de beneficiar os outros e não prejudicar em único princípio, o da beneficência. Por isto, ao invés de apresentarem uma ordem hierárquica, incorporam nos princípios de não maleficência e beneficência um arranjo com quatro normas, sendo que sob o primeiro encontram-se as exigências de não causar mal ou dano e no segundo as de prevenir o mal ou dano; de eliminar o mal ou dano e de fazer ou promover o bem.

As normas abarcadas pela não maleficência apenas exigem intencionalmente refrear-se de atos que causem dano, tendo suas regras a forma de proibição, ou seja, de "não fazer X", ao passo que as de beneficência requerem uma ação direta de ajuda, seja prevenindo ou eliminando o dano, seja promovendo o bem. Assim, na opinião de Beauchamp e Childress, a compactação das obrigações de não maleficência e beneficência em um único principio não propicia a percepção de que as obrigações de não prejudicar os outros (não roubar, não mutilar e não matar) são diferentes das de ajudá-los (prover beneficios, proteger interesses e promover bem estar). 
As obrigações de não causar danos são, algumas vezes, mais estritas do que as de ajudar, contudo podem ocorrer situações nas quais as obrigações de beneficência apresentam-se mais exigentes do que as de não maleficência. Em geral, quando o mal causado é pequeno, como o inchaço de uma punção venosa e o beneficio provido maior, como uma intervenção que salva a vida, então a tendência é atribuir à obrigação de beneficência prioridade sobre a de não maleficência.

Desta forma, na opinião dos autores, dever-se-ia reformular a idéia exacerbada da rigorosa observância do princípio da não maleficência da seguinte maneira: "geralmente, as obrigações de não maleficência são mais estritas do que as obrigações de beneficência e, em alguns casos, a não maleficência sobreexcede a beneficência, mesmo quando o melhor resultado utilitarista seria obtido por se agir beneficentemente" (p. 115).

Nos casos de conflito, usualmente a não maleficência é sobreexcedente, mas o peso deste princípio - como dos demais - variam nas diferentes circunstâncias. De acordo com os autores, não há, na ética, regra alguma determinadora de que, em todas as circunstâncias, evitar danos deve prevalecer sobre prover benefícios. Da mesma maneira, uma ação danosa pode não ser errada ou injustificada no balanço. Embora, atos que causem danos, em geral, sejam prima facie errados por obstaculizarem os interesses da pessoa afetada, ações que causem danos, mas envolvam obstaculizações justificadas dos interesses de outros não podem ser tidas como erradas.

Destacam os autores que alguns entendimentos de dano ampliam-se tanto que chegam a abarcar os obstáculos a interesses na reputação, propriedade, privacidade e liberdade, além das condições que restringem a ação autônoma, como desconforto, humilhação, ofensa e perturbação. Em contrapartida, explanações com foco mais estreito compreendem danos apenas enquanto obstáculos a interesses físicos e psicológicos, como os relativos à saúde e sobrevivência. Apesar destas controvérsias, há concordância quanto ao fato de que danos físicos e outros obstáculos aos 
interesses de outrem podem ser tomados como exemplos paradigmáticos do que vem a ser dano. Beauchamp e Childress admitem concentrar-se nos danos físicos, especialmente a dor, a incapacidade e a morte, sem, no entanto, negar a importância dos danos mentais e dos obstáculos aos interesses dos outros.

Do princípio da não maleficência decorrem outras regras morais de cunho mais especifico, como não matar; não causar dor ou sofrimento; não incapacitar; não ofender; não privar os outros dos bens da vida.

A não maleficência alcança também as obrigações de não impor riscos de danos. A moralidade e a lei reconhecem um padrão de cuidado devido que determina se o agente é causalmente responsável pelo risco e permite a imputação legal e moral. Por cuidado devido, compreende-se cuidar de maneira suficiente e apropriada para evitar causar danos, tal qual é exigido de pessoas prudentes e sensatas. A má prática profissional constitui exemplo de negligência causada pela inobservância dos padrões profissionais de cuidado. Entretanto, os autores alertam que, mesmo quando o relacionamento terapêutico é danoso ou de não ajuda, a má prática ocorre se, e somente se, os padrões profissionais de cuidado forem desrespeitados. A linha entre cuidado devido e aquele que fica aquém ou além deste limite, freqüentemente, é dificil de ser traçada.

Segundo os autores, um curto passo separa a premissa de que se pode e devese proteger as pessoas contra alguns danos e a conclusão que há uma obrigação positiva de prover-lhes benefícios, como os cuidados à saúde. Este passo pode encurtar ainda mais, graças à incerteza conceitual e moral que cerca as distinções entre as obrigações de evitar danos a outros; de beneficiá-los e de tratá-los justamente.

\subsubsection{BENEFICÊNCIA}

Para a ética biomédica é central prover beneficios; prevenir e eliminar danos; pesar e balançar os possíveis bens de uma ação contra seus custos e possíveis danos. 
Além do mais, há uma implícita assunção de beneficência nas profissões de saúde e em seu contexto institucional, sendo seu objetivo, racional e justificativa a obrigação de promover o bem dos pacientes, ultrapassando o simples evitar danos.

Beauchamp e Childress diferenciam a beneficência em geral, o principio da beneficência e a benevolência. A primeira refere-se a uma ação feita para beneficiar outros, enquanto que a última diz respeito ao traço de caráter ou virtude que leva à disposição para agir em beneficio dos outros. Por outro lado, o principio da beneficência configura uma obrigação moral de agir para o benefício dos outros, passando também por uma divisão em outros dois princípios: o da beneficência positiva, que requer que os agentes propiciem beneficios e o da utilidade, que exige dos agentes um balanço dos beneficios e desvantagens com vistas a produzir o melhor resultado possível. O princípio da utilidade consiste numa extensão do principio positivo da beneficência, sendo necessário este alargamento porque na vida moral é impossivel produzir beneficios ou eliminar danos sem criar riscos ou incorrer em custos. A fim de ser apropriadamente beneficente, uma ação tem de originar beneficio suficiente para compensar seus custos.

Os autores esclarecem que o princípio de utilidade, enquanto desdobramento do princípio da beneficência, não equivale ao princípio de utilidade do utilitarismo. Este constitui um princípio absoluto ou sobreexcedente, ao passo que aquele não pode ser interpretado como o princípio único da ética e tampouco como o que justifica ou sobrepuja os demais, ou seja, é um dentre diversos princípios prima facie. Além disto, o princípio da utilidade ou proporcionalidade, como propõem, limita-se ao balanço dos prováveis resultados das ações - beneficios, danos e custos - a firm de alcançar o mais alto beneficio líquido, mas não determina o balanço global das obrigações, ou seja, pode ser legitimamente restringido pelos demais, o que não acontece no utilitarismo.

No escopo do princípio da beneficência positiva encontra-se um conjunto de regras morais mais especificas, como proteger e defender os direitos dos outros; 
prevenir danos que possam ocorrer a outros; eliminar condições que podem causar danos a outros; ajudar pessoas com incapacidades e resgatar pessoas em perigo.

Embora várias teorias éticas empreguem o termo beneficência para identificar obrigações positivas para com os outros, não é rara a argumentação negando a existência destas e sustentando que constituem ideais virtuosos ou atos de caridade. Desta forma, os que falham em agir de maneira beneficente não poderiam ser tidos como moralmente defectivos. Estas considerações, na opinião dos autores, apontam para a necessidade de clarificar e especificar a beneficência, com atenção para denotar os limites das obrigações e identificar em que condições ou circunstâncias a beneficência é mais opcional, mais do que obrigatória.

Parece ser concorde, na opinião de Beauchamp e Childress, que não há na moral comum princípio algum de beneficência que requeira sacrificios severos e altruísmo extremo, como doar ambos rins para transplante. Somente ideais de beneficência incorporam tal generosidade extrema. Não há, então, uma exigência moral de beneficiar as pessoas em todas as ocasiões, mesmo quando isto é possível. Desta forma, pode-se anuir que muito da conduta beneficente inscreve-se no âmbito do ideal moral, e não do obrigatório, sendo a linha demarcatória entre a obrigação e o ideal moral, freqüentemente, pouco clara no caso da beneficência.

As normas de beneficência, algumas vezes, estabelecem obrigações suficientemente fortes para sobreexceder as de não maleficência. Por exemplo, as obrigações de beneficência podem se aliar às demandas do princípio da utilidade, tornando o beneficiar sobrepujante quando é possível produzir um beneficio maior com um dano menor ou ainda se um beneficio maior pode ser atingido para um grande número de pessoas, provocando-se um dano menor para um grupo diminuto. Muitos programas de saúde pública, como os de vacinação, causam danos a certas parcelas da população ao mesmo tempo em que proporcionam um bem maior a outras tantas partes dela. Estas ações seriam injustificadas se não houvesse obrigação de beneficência, mas somente ideais morais de tal ordem. Então, não é sempre que a não maleficência sobreexcede ou tem prioridade em relação à beneficência. 
Os autores ainda fazem uma distinção entre beneficência geral e específica. A última, como indica o próprio nome, dirige-se a terceiros específicos, enquanto a geral volta-se para todas as pessoas e, cercada pela controvérsia, tem sido alvo de várias justificativas. Neste sentido, Beauchamp e Childress, embora reconheçam que a reciprocidade não possa justificar o leque completo das obrigações de beneficência, defendem uma abordagem baseada na reciprocidade, por a considerarem a mais adequada para a ética biomédica.

Por reciprocidade entendem o ato ou a prática de proceder ao proporcional retorno. Por exemplo, retornar o beneficio por proporcional benefício, o dano por proporcional pena criminal e a amizade por proporcional gratidão. As obrigações de beneficência para com a sociedade, na visão dos autores, sendo diferentes das que existem para com os indivíduos identificados, configuram alguma forma de reciprocidade. A defesa de uma liberdade tal que desconheça as dívidas para com os pais, os pesquisadores da medicina e da saúde pública, os educadores e as instituições sociais, como a escola é tão irrealista quanto à idéia que é sempre possível agir autonomamente sem afetar os demais. Na verdade, muitas obrigações de beneficência ficam justificadas através de arranjos implícitos que incorporam o necessário dar-e-receber da vida social.

Os autores consideram equivocado o tradicional entendimento dos códigos de ética médica que vêem estes profissionais como independentes, auto-suficientes e filantropos, com beneficência similar à que rege os atos generosos de doação. Isto porque acreditam que tanto os médicos quanto os outros profissionais de saúde têm um débito para com a sociedade, pela educação e privilégios e para com os pacientes, devido à pesquisa e prática. Graças a esta dívida, é errôneo moldar o papel de beneficência do profissional de saúde primariamente na filantropia, no altruísmo e no compromisso pessoal. Ao invés disto, este tem de ser enraizado na "reciprocidade de dar e receber" que cria uma obrigação de beneficência geral para com o paciente e a sociedade, ainda que seja dificil especificar, de maneira precisa, os termos desta obrigação (p. 175). 
Um problema central na ética biomédica é a disputa de prioridade entre os princípios do respeito à autonomia dos pacientes e da beneficência que orienta o agir profissional. Beauchamp e Childress argumentam que este debate não pode ser resolvido com a mera defesa a favor de um princípio em prejuizo do outro ou pela tentativa de tornar um deles absoluto. Nem o paciente e tampouco o médico gozam de autoridade sobrepujante, sendo que nenhum princípio tem proeminência na ética biomédica, nem mesmo a obrigação de agir no melhor interesse do paciente. A beneficência provê o objetivo primário e o racional da atenção à saúde, enquanto o respeito à autonomia - junto com a não maleficência e a justiça - estabelecem os limites morais para as ações profissionais na persecução de seus objetivos.

\subsubsection{JUSTIÇA}

A justiça distributiva abarca a distribuição justa, eqüitativa, apropriada e determinada por normas justificadas que estruturam os termos da cooperação social. Refere-se à distribuição dos direitos e responsabilidades na sociedade, incluindo os direitos civis e políticos.

Os problemas de justiça distributiva ganham destaque sob condições de escassez e competição para obter bens ou evitar penalizações. Em situações de escassez, a sociedade é, às vezes, forçada a fazer "escolhas trágicas", infringindo, comprometendo ou sacrificando os princípios de justiça (p. 227).

Assim, as questões concernentes à justiça distributiva remetem aos debates acerca dos princípios de justiça e, como destacam Beauchamp e Childress, não há um único princípio capaz de encaminhar todos os problemas nesta área. A exemplo da subdivisão que ocorre com a beneficência, há na moral comum vários princípios de justiça que precisam ser especificados e ponderados em contextos particulares, com vistas a sua consistência. 
Segundo os autores, há um requerimento formal mínimo, tradicionalmente atribuído a Aristóteles, que afirma: "os iguais devem ser tratados igualmente e os desiguais devem ser tratados desigualmente" (p. 227). Este princípio de justiça, também chamado de princípio de igualdade formal, é tido como "formal" por não identificar nenhum aspecto particular no qual os iguais devem ser tratados igualmente e não prover nenhum critério para determinar se dois ou mais indivíduos são, de fato, iguais. Meramente afirma que, sejam quais forem os aspectos relevantes, as pessoas iguais naqueles aspectos devem ser tratadas igualmente.

Os principios que especificam as características relevantes para o tratamento igual são chamados materiais, porque identificam as propriedades substantivas para a realização da justiça distributiva. As políticas públicas ou institucionais que tomam por base a justiça distributiva, em última instância, decorrem da aceitação ou rejeição de certos princípios materiais de justiça e de procedimentos para especificar, refinar ou ponderá-los. Assim, muitas das disputas acerca da política correta para distribuição de bens decorrem do fato de partirem de pontos iniciais distintos que tomam por referência princípios materiais de justiça que se não são rivais, ao menos, são alternativos.

Dentre os princípios materiais de justiça distributiva, na visão de Beauchamp e Childress, encontram-se:

- a cada pessoa uma parte igual;

- a cada pessoa de acordo com a necessidade;

- a cada pessoa de acordo com o esforço;

- a cada pessoa de acordo com a contribuição;

- a cada pessoa de acordo com o mérito;

- a cada pessoa de acordo com as transações do livre mercado.

Não há nada que impeça a aceitação de mais de um destes princípios, tanto é assim que algumas teorias de justiça acatam os seis como válidos e a maioria das sociedades invoca vários deles ao formular suas politicas públicas, de acordo com as 
distintas esferas e contextos. Beauchamp e Childress consideram uma tese plausivel admitir que cada um dos princípios materiais identifica uma obrigação moral prima facie, cujo peso não pode ser avaliado independentemente dos contextos particulares ou das esferas nas quais são aplicáveis.

$\mathrm{Na}$ opinião dos autores, as teorias de justiça distributiva mais influentes são: teorias utilitaristas, lançam mão de uma mescla de critérios para o propósito de maximizar a utilidade pública; teorias liberais ${ }^{9}$, enfatizam os direitos à liberdade econômica e social, priorizando a justiça dos procedimentos em lugar dos resultados substantivos; teorias comunitárias, estressam os princípios e práticas de justiça que evolvem das tradições e práticas da comunidade e teorias igualitárias, defendem o acesso igual aos bens, freqüentemente invocando critérios materiais de necessidade e igualdade.

Ao tentar trazer consistência e compreensão para as fragmentadas visões de justiça social, estas teorias obtêm apenas um sucesso parcial e as políticas públicas para acesso e distribuição dos cuidados à saúde, em muitos países, constituem exemplo dos problemas a serem enfrentados por elas. Os objetivos de cuidado excelente, igualdade de acesso, liberdade de escolha e eficiência social podem ser louváveis, entretanto são de dificil consistência em um sistema social. Diferentes concepções de sociedade justa sublinham-nos e a persecução de um objetivo parece aniquilar o outro. Entretanto, as várias teorias de justiça tentam alcançar um balanço entre objetivos rivais ou eliminar alguns deles, mantendo outros.

Assim, para Beauchamp e Childress, as diferentes teorias de justiça social que foram construídas ao longo da história da humanidade têm, cada qual, suas características atrativas e não atrativas, o que gera, para muitos, um compreensível temor acerca das conseqüências para a sociedade de se adotar um único sistema filosófico como base da justiça na saúde. A experiência sugere que as exigências de

\footnotetext{
${ }^{9}$ Do inglês "libertarian theories" (BEAUCHAMP e CHILDRESS 2001 p. 203). Opta-se pelo uso da palavra liberal como tradução de libertarian, pois, segundo Lalande (1999, p. 624), libertário é um termo novo, empregado em dois sentidos. O mais freqüente equivale a partidário da teoria anarquista e o segundo é sinônimo de liberal, entretanto este sentido é raro e impróprio.
} 
uma teoria de justiça podem funcionar bem em alguns contextos, mas produzir resultados desastrosos em outros. Cada teoria de justiça propicia a reconstrução filosófica de uma perspectiva válida da vida moral, porém capta apenas parcialmente sua amplitude e diversidade.

$\mathrm{Na}$ ausência de um consenso social, os autores consideram plausivel que as políticas públicas ora enfatizem uma teoria de justiça e ora outra. Entretanto, alertam que a existência destas teorias rivais de justiça não justifica a fragmentada abordagem que muitos países, incluindo os Estados Unidos, têm dedicado a este aspecto do sistema de saúde. Esta fragmentação impede que se debatam questões mais abrangentes de justiça, como as relativas ao que as pessoas esperam do sistema de saúde de sua nação e como o Estado deve lidar com as necessidades dos cidadãos.

Evocando a teoria de justiça de John Rawls e sua interpretação para a saúde constante na proposta de Norman Daniels, Beauchamp e Childress incluem-se entre os defensores da regra da justa oportunidade. Entendem que esta regra exige que a ninguém sejam destinados ou negados beneficios sociais com base nas propriedades imerecidas, de cunho vantajoso ou desvantajoso, pois sendo estas distribuídas pela loteria social e biológica da vida não podem prover fundamento para uma discriminação moralmente aceitável, já que as pessoas não têm chance de adquiri-las ou superá-las. Ao contrário, a regra da justa oportunidade requer que cada qual receba os beneficios necessários para amenizar ou corrigir os efeitos deletérios decorrentes dos infortúnios da loteria da vida.

Por analogia, é possível concluir, como destacam, que os portadores de incapacidades funcionais necessitam de cuidados para alcançar um nivel melhor de função e ter uma justa chance na vida, ou seja, como não são responsáveis pela sua condição, a regra da justa oportunidade requer que recebam tudo que os ajudará a atenuar ou corrigir os efeitos ruins para a saúde causados pela loteria da vida. Por outro lado, se a pessoa for responsável por suas incapacidades, o direito aos cuidados de saúde desaparece, sendo justo negar-lhe tal beneficio. 
Frente a regra da justa oportunidade, os autores consideram que a questão primária é se o governo deveria se envolver na alocação e distribuição dos cuidados à saúde, ao invés de deixá-los ao sabor do mercado. Neste sentido, admitem que a regra de capacidade para pagar não deve constituir o único princípio de justiça distributiva a pautar o acesso aos bens e serviços de saúde.

Desta questão, segundo Beauchamp e Childress, decorre um importante aspecto do direito aos cuidados de saúde que se refere à especificação de seus limites e critérios. Duas visões de maior influência têm se destacado, a do igual acesso e do minimo decente. Para os autores, ambas são igualitárias: a primeira promove o acesso igual a todos os recursos de saúde tidos como de boa fé e a segunda, partindo de uma visão enfraquecida de igualdade, defende o acesso igual apenas aos recursos tidos como essenciais.

Frente a temas complexos como o das políticas de justo acesso e financiamento dos cuidados de saúde e o das estratégias para eficiência das instituições sanitárias, os autores ressaltam que as outras questões sociais tratadas no livro têm sua importância reduzida. Compreendem que ainda existem muitas barreiras no acesso aos cuidados à saúde e para os milhões de pessoas que com elas se deparam, um sistema de saúde justo permanece como um objetivo distante. Embora toda sociedade deva limitar o acesso aos cuidados de saúde através de alguns mecanismos, muitas estão um passo aquém e têm de diminuir os abismos no acesso de maneira mais firme do que têm feito até então. A proposta dos autores é que a sociedade reconheça e reforce um direito a um mínimo decente de cuidados a saúde, dentro de uma estrutura de alocação que incorpore tanto padrões utilitaristas quanto igualitários. 


\subsection{O ENFOQUE DAS VIRTUDES: A ÊNFASE NO CARÁTER DOS AGENTES}

Virtude é a tradução do termo grego arete que significa qualquer forma de excelência. Aristóteles, segundo citação de HAUERWAS (1995), define virtude como "uma espécie de segunda natureza" que dispõe não apenas a fazer a coisa certa de forma correta, mas a ter prazer com o que se faz. Os homens têm potencialidades naturais para as virtudes que devem ser intensificadas através do hábito ${ }^{10}$, que é entendido como o meio de formar precocemente o caráter ${ }^{11}$ através de um acostumar-se suave e progressivo, e não uma repetição mecânica e forçada (HAUERWAS 1995; VERGNIÈRES 1998).

Os filósofos da Antiguidade e os teólogos cristãos, apesar de partirem de diferentes entendimentos do que vem a ser virtude, concordam que qualquer compreensão de viver bem deve tomá-la em consideração. Na modernidade, quando as virtudes são tratadas, aparecem como algo secundário à ética baseada nos princípios e valores. William Frankena (1973), citado por HAUERWAS (1995), defende que a teoria ética deve se ocupar com a justificativa da moral e com os esclarecimentos das diferenças entre os apelos para o dever e as conseqüências. As virtudes constituem suplementos na determinação da correção ou incorreção de um ato e são vistas como o componente motivacional dos principios éticos. Para o autor, duas virtudes devem ser cultivadas: a benevolência, disposição para ser beneficente e a justiça, inclinação para tratar as pessoas igualmente. Entretanto, nas éticas deontológicas, a função delas não consiste em determinar o que deve ser feito e sim

\footnotetext{
10 "O hábito, no sentido mais vasto, é a maneira de ser geral e permanente, o estado de uma existência considerada quer no conjunto de seus elementos, quer na sucessão das suas épocas." (LALANDE 1999, p. 453).

"O sentido geral e etimológico de caráter compreende "signo distintivo que serve para reconhecer um objeto. Em particular tudo aquilo que distingue um ser, quer na sua estrutura, quer nas suas funções". Em ética, é entendido como "posse de si, firmeza e acordo consigo mesmo". (LALANDE 1999 , p. 136 e 137). Aristóteles distingue na alma uma parte que possui o logos (discurso racional) e outra que não o tem. A primeira é a sede das virtudes intelectuais, podendo ser educada pelo ensinamento e exercicio. A segunda, por sua vez, comporta outras duas partes: a vegetativa, não educável e a desejante, capaz de escutar e seguir o logos por menos que receba a educação apropriada. O hábito é o meio desta educação; o ethos ou o caráter o seu resultado, que pode, então, ser entendido como fruto dos hábitos adquiridos em matéria de prazer ou de pena (VERGNIĖRES 1999, p. 84).
} 
assegurar que o sujeito ético agirá, com boa vontade, segundo o dever, em qualquer situação (HAUERWAS 1995).

Este entendimento da ética é particularmente assumido pela bioética em seus primórdios, que vê a virtude como a motivação para a ação e compreende que a descrição de um ato pode ser abstraída do caráter do agente. No livro Principles of Biomedical Ethics, Tom L. Beauchamp e James F. Childress mantêm a proposta de Frankena, fundamentando a ética biomédica em torno das alternativas normativas das teorias utilitaristas e deontológicas e dos princípios da autonomia, não maleficência, beneficência e justiça. Assim, a cada um dos principios fundamentais, ainda que imperfeitamente, correlaciona-se uma virtude primária que não desempenha papel central (GRACIA 1991; HAUERWAS 1995; BEAUCHAMP e CHILDRESS 1999):

\begin{tabular}{ll}
\hline Princípios & Virtudes correspondentes \\
\hline Autonomia / respeito à autonomia & Respeitabilidade \\
Não maleficência & Não malevolência \\
Beneficência & Benevolência \\
Justiça & Justiça \\
\hline
\end{tabular}

O renovado interesse pela natureza e importância da ética das virtudes é estimulado pelo trabalho de Alasdair MacIntyre, After Virtue, editado em 1981. O autor concorda que os princípios e as regras são importantes para a ética, mas rejeita a tentativa de justificá-los isoladamente de suas raizes cravadas nas particularidades históricas de comunidades concretas. A defesa de MacIntyre é uma alternativa ao desafio de tentar assegurar um acordo entre pessoas que têm em comum apenas a necessidade de cooperar no interesse pela sobrevivência (HAUERWAS 1995).

É, então, a segunda edição do livro After Virtue de Alasdair MacIntyre, publicada em 1984 (MACINTYRE 1984), que serve de base para a elaboração do referencial das virtudes, no presente estudo. 
Segundo o próprio autor, a natureza e a concepção das virtudes que desenvolve partem da defesa da tradição moral aristotélica como o melhor exemplo disponivel de uma tradição que, racionalmente, outorga a seus seguidores um alto grau de confiança em seus recursos morais e epistemológicos.

Para MacIntyre, "uma virtude é uma qualidade humana adquirida cuja possessão e exercício tendem a capacitar-nos para realizar os bens que são internos às práticas e cuja falta impede-nos de realizar tais bens" (p. 191). Sua explicação das virtudes prossegue através de três estágios: um primeiro que diz respeito às virtudes como qualidades necessárias para realizar bens internos às práticas; um segundo que as considera como qualidades contribuintes para o bem de toda uma vida e um terceiro que as relaciona à persecução de um bem para os seres humanos, cuja concepção somente pode ser elaborada e possuída dentro de uma contínua tradição social. São essenciais, então, os conceitos de prática, unidade narrativa da vida e de telos da vida humana.

\subsubsection{NATUREZA E NOÇÃO DAS VIRTUDES NA EXPLICAÇÃO DE ALASDAIR MACINTYRE}

Existem diferentes e incompativeis concepções de virtude $e$ isso ocorre mesmo dentro da tradição de pensamento que Alasdair MacIntyre esquematiza em sua obra, como destaca o próprio autor. Esta diversidade é tal que parece difícil encontrar uma unidade para o conceito ou a história das virtudes. Homero, Sófocles, Aristóteles, o Novo Testamento e os pensadores medievais diferem uns dos outros em várias maneiras. Oferecem listas de virtudes distintas, inconciliáveis e com discordantes ordens de importância nas escalas. Ao se considerar escritores ocidentais mais tardios, estas discrepâncias e divergências tendem a aumentar e estender a investigação para os povos orientais, como os japoneses ou para as culturas dos índios americanos faria as diferenças crescerem ainda mais. A conclusão 
de que há um sem número de concepções e alternativas rivais para as virtudes parece ficar evidente.

Uma vez que os vários autores incluem distintos conjuntos e tipos de itens em suas listas de virtudes, em diferentes épocas e lugares, mas dentro de uma só história da cultura ocidental, MacIntyre questiona em que bases seria possível supor que aspiram listar itens de um único e mesmo tipo e que compartilham um conceito em comum. Uma negativa parece ser a resposta mais óbvia a esta questão, pois além de cada um dos diversos autores arrolar distintas espécies de itens, também cada rol corporifica e expressa uma teoria diferente acerca da virtude.

Nos poemas homéricos, virtude é uma qualidade cuja manifestação capacita alguém para fazer exatamente o que seu papel social bem definido requer. Assim, é impossivel identificar as virtudes homéricas sem primeiro reconhecer os papéischave na sociedade e as exigências atreladas a cada um.

Para Aristóteles, ainda que algumas virtudes estejam disponiveis apenas para certos tipos de pessoas, não se vinculam ao fato destas serem depositárias de um papel social, mas ao humano como tal. O telos da espécie humana determina as qualidades apreciadas como virtudes e seu exercício configura um componente crucial da vida "boa".

A explicação do Novo Testamento segue a mesma estrutura lógica e conceitual da visão aristotélica, embora apresente divergências em relação ao conteúdo. Uma virtude é, da mesma maneira que em Aristóteles, uma qualidade cujo exercício leva ao alcance do telos humano. $\mathrm{O}$ bem humano não consiste somente em um bem natural, mas sobrenatural, pois este redime e completa a natureza. Ademais, tal qual em Aristóteles, o relacionamento das virtudes como meios para o fim que é a incorporação humana no reino divino com a chegada dos tempos, apresenta-se como algo interno e não externo. Uma característica central a ambas é que o conceito de vida "boa" antecede ao de virtude, da mesma maneira que na explicação homérica a 
concepção de papel social ocorre a priori. A aplicação do primeiro conceito determina a utilização do último, ou seja, a noção de virtude é secundária.

Dentre os autores mais tardios que escrevem sobre as virtudes, Macintyre destaca a explanação de Benjamim Franklin que, como a de Aristóteles, é teleológica, mas difere desta ao se mostrar utilitarista. Para Franklin, as virtudes configuram meios para um fim, porém entende esta relação de meios e fins como externa e não interna. O fim ao qual o cultivo das virtudes serve é a felicidade, entendida como sucesso, primeiro na terra e, em última instância, no céu. As virtudes têm de ser úteis, desta maneira vê-se reforçada a utilidade como um critério para os casos individuais.

Há então, para o autor, ao menos três concepções muito diferentes de virtude: como uma qualidade que capacita um individuo a desempenhar seu papel social (Homero); enquanto uma qualidade que possibilita o movimento do indivíduo rumo à realização de um telos especificamente humano, seja natural ou sobrenatural (Aristóteles e o Novo Testamento) e como uma qualidade útil na consecução do sucesso, na terra e no céu (Franklin).

Entretanto, a despeito das diferenças, MacIntyre considera que estas explanações para as virtudes esquematizadas sumariamente em sua obra, de fato, corporificam apenas uma única asserção. Cada uma requer, além da hegemonia teórica, a institucional. $\mathrm{Na}$ Odisséia, os ciclopes permanecem condenados porque lhes falta a agricultura, agora e themis ${ }^{12}$; Aristóteles reprova os bárbaros por não possuírem a polis e, portanto, serem incapazes de fazer política; para os cristãos do Novo Testamento não há salvação fora da igreja apostólica e Benjamim Franklin vê na Filadélfia, antes do que em Paris, o local mais propicio para a origem das virtudes.

Até então, para o autor, um dos traços que marca a concepção de virtude e que emerge com alguma claridade é que esta requer, para sua aplicação, a aceitação de certas características da vida moral e social em termos das quais é definida e

\footnotetext{
${ }^{12}$ Segundo Maclntyre, o conceito homérico de themis é o da lei costumeira compartilhada pelas pessoas civilizadas.
} 
explicada. Assim, na visão homérica a noção de virtude é secundária ao entendimento de papel social, em Aristóteles ao de vida boa que configura o telos da ação humana e para Franklin ao de utilidade.

$\mathrm{Na}$ visão homérica, o exercício das virtudes implica em qualidades que são requeridas para sustentar um papel social e propiciar a excelência em alguma área definida da prática social. Aristóteles quando fala da excelência na atividade humana, refere-se, por vezes, a algum tipo bem determinado de prática humana, como a guerra, a geometria ou tocar flauta. MacIntyre, então, sugere que esta noção de um tipo particular de prática como a arena na qual as virtudes são exibidas e em termos das quais recebem sua primeira, ainda que incompleta, definição é crucial para a empreitada de identificar uma explanação central de virtudes.

Por prática, o autor entende qualquer forma coerente e complexa de atividade humana cooperativa, socialmente estabelecida, cujos bens internos inerentes são concretizados no transcurso da tentativa de realizar os padrões de excelência apropriados e parcialmente definidos para esta atividade, resultando na expansão sistemática dos poderes humanos para operar a excelência e das concepções humanas dos fins e bens envolvidos. Assentar tijolos ou plantar nabos não constituem práticas, mas a arquitetura e a agricultura o são, assim como as investigações de física, química e biologia, o trabalho do historiador, a pintura e a música. Nos mundos antigo e medieval, a criação e a manutenção de comunidades humanas - famílias, cidades, nações - é geralmente tomada como uma prática no sentido definido por MacIntyre. Desta forma, o espectro das práticas é amplo e inclui as artes, as ciências, os jogos, a politica (não no sentido aristotélico), o estabelecimento e a conservação da vida da família.

Entretanto, segundo MacIntyre, a discussão acerca do exato alcance das práticas tem menos importância do que a explicação dos termos-chave envolvidos em sua definição, começando com a noção de bens internos. Para esta explanação, o autor lança mão de um exemplo com o jogo de xadrez que está transcrito, de maneira resumida, a seguir: 
Há uma criança de 7 anos de idade, extremamente inteligente que, a despeito de sua vontade, alguém quer ensinar a jogar xadrez. A criança, porém, deseja obter doces e tem poucas chances para consegui-lo. Este alguém, então, oferece guloseimas à criança para que esta jogue com ele uma vez por semana, acrescentando que, em caso de vitória, ganhará uma porção extra. A pessoa informa que fará jogadas com certo nivel de dificuldade, mas não a ponto de impossibilitar que a criança jogue. Assim motivada, a criança joga e para ganhar. Contudo, como é o doce que configura para a criança uma boa razão para jogar xadrez, não há razão para não trapacear, pelo contrário, não faltam motivos para tal, desde que a criança obtenha sucesso nisso. Mas, como esclarece o autor, é possível que sobrevenha o momento em que a criança encontre nos bens específicos do xadrez - realização de um certo tipo de habilidade analítica altamente específica, imaginação estratégica e intensidade competitiva - um novo conjunto de razões, não para ganhar em alguma ocasião em particular e sim para tentar exceder quaisquer que sejam as exigências do xadrez. Neste momento, se a criança trapaceia não estará enganando mais a quem está lhe ensinando o jogo, mas a si mesma.

Jogar xadrez, então, propicia a consecução de duas espécies de bens: os externos e os internos. Os externos e contingenciais são vinculados a este jogo e também a outras práticas pelo fortuito das circunstâncias sociais, como prestígio, status e dinheiro, ou seja, para a consecução de tais bens existem meios alternativos e sua realização não depende única e exclusivamente do engajamento em algum tipo muito particular de prática. Por sua vez, os bens internos à prática do jogo de xadrez não podem ser obtidos de outro jeito que não jogando xadrez. São chamados bens internos porque só é possível especificá-los lançando mão de exemplos de práticas como feito com o jogo de xadrez - e somente podem ser identificados e reconhecidos pela experiência de participar da prática em questão. Os que não têm a experiência relevante da prática também são incompetentes como juízes dos bens internos.

Parece, então, que os bens internos e externos a uma prática distinguem-se de maneira importante e crucial. Os bens externos, marcantemente, correspondem a 
alguma propriedade ou possessão individual. Assim, quanto mais alguém tem deles, menos sobra para as outras pessoas, configurando-os, portanto, como objetos de disputas nas quais, necessária e caracteristicamente, deve haver perdedores e ganhadores. Ao passo que, os bens internos decorrem, na verdade, da competição para exceder-se no rumo à excelência, sendo que sua realização representa um bem para toda comunidade participante da prática.

Uma prática envolve padrões de excelência, obediência às regras e consecução dos bens. Entrar em uma prática significa aceitar a autoridade dos padrões e a inadequação de seu próprio desempenho a seus ditames, ou seja, é submeter as próprias atitudes, escolhas, preferências e gostos aos padrões definidos pela prática. Sejam jogos, ciências ou artes, as práticas, como destaca o autor, têm uma história. Desta forma, os padrões estabelecidos são passíveis de criticismo, entretanto, a iniciação em uma prática não pode ocorrer sem a aceitação da autoridade dos melhores padrões reconhecidos até então.

Destas considerações, para MacIntyre, emerge uma primeira e parcial definição de virtude:

\begin{abstract}
"Uma virtude é uma qualidade humana adquirida, cuja possessão e exercício tendem a capacitar-nos para realizar os bens que são internos às práticas e cuja falta impede-nos de realizar tais bens". (p. 191)
\end{abstract}

Esta noção indica o lugar das virtudes na vida humana, não sendo dificil, na opinião do autor, mostrar que existe um leque de virtudes-chave sem as quais os bens internos às práticas são impossiveis de serem alcançados.

É inerente ao conceito de prática delineado por MacIntyre, o fato de seus bens poderem ser realizados somente através da subordinação própria no relacionamento com outros praticantes. Quem adentra a uma prática tem de aprender a reconhecer o que é devido a quem; estar preparado para assumir quaisquer que sejam os riscos de 
auto exposição ao perigo que são requeridos ao longo da jornada e escutar atentamente ao que é contado sobre as próprias inadequações, respondendo com a mesma atenção para estes fatos. Em outras palavras, as virtudes da justiça, coragem e honestidade têm de ser aceitas enquanto componentes necessários de qualquer prática com bens internos e padrões de excelência. Ao não aceitá-las, por exemplo, com a execução de trapaças, fica impedida a realização dos padrões de excelência ou dos bens internos à prática, rendendo a esta uma falta de sentido, exceto como um estratagema para a consecução dos bens externos.

Toda prática, então, requer um certo tipo de relação entre os que dela participam. Conseqüentemente, as virtudes passam a conformar os bens por referência aos quais, se goste ou não, são definidos os relacionamentos entre as pessoas que compartilham as propostas e os padrões constituintes das práticas. $O$ autor apresenta o exemplo que segue:

A, B, C e D são amigos no sentido de amizade que Aristóteles toma como primária: compartilham a persecução de certos bens. Nos termos de Macintyre, compartem uma prática. D morre em circunstâncias obscuras, A descobre como D morreu e conta a verdade sobre isso para $\mathrm{B}$, enquanto mente para $\mathrm{C}$. $\mathrm{C}$ descobre a mentira. A não pode, então, inteligivelmente, reclamar que mantém o mesmo relacionamento de amizade com B e C. Por contar a verdade para um e mentir para o outro, define uma diferença no relacionamento. Obviamente, fica aberta a possibilidade de A explicar esta distinção de várias maneiras. Talvez estivesse tentando poupar $\mathrm{C}$ de uma dor ou simplesmente enganando-o. Porém, é inegável que existe alguma diferença no relacionamento, como resultado da mentira. Por causa disto, a fidelidade de uns para com os outros na persecução dos bens em comum é passivel de questionamento.

Assim, na medida em que se compartem os padrões e as propostas típicas das práticas, define-se, seja isto reconhecido ou não, o relacionamento de uns para com os outros por referência a padrões de honestidade e confiança, além de justiça e coragem. Na explicação de MacIntyre, a justiça exige que as pessoas sejam tratadas 
de maneira uniforme e impessoal, de acordo com o mérito por louvor ou merecimento de castigo. $\mathrm{O}$ afastamento dos padrões de justiça denota um relacionamento especial ou distintivo entre as pessoas.

Com a coragem ocorre de maneira um pouco diferente. Esta, para MacIntyre, é uma virtude porque o cuidado e a preocupação para com os indivíduos, as comunidades e as causas, que são tão cruciais nas práticas, requerem sua existência. Se alguém diz que cuida de algum indivíduo, comunidade ou causa, mas não a ponto de expor seus próprios interesses ao risco de danos ou perigos, permite que se lancem dúvidas acerca da genuinidade de seu cuidado e preocupação. Isto não significa que não se possa genuinamente cuidar e ao mesmo tempo ser covarde. Mas, quer dizer que este alguém que genuinamente cuida e não tem a capacidade de arriscar-se ao dano ou perigo tem que se definir, tanto para si próprio quanto para os outros, como um covarde.

Desta forma, o autor afirma que, tomando-se em conta a perspectiva destes tipos de relacionamento sem os quais as práticas não podem ser concretizadas, a honestidade, a confiança e a coragem configuram genuinas excelências. Constituem virtudes à luz das quais as pessoas têm que caracterizar a si mesmas e aos outros, independentemente de seu ponto de vista moral privado ou do código da sociedade em particular onde vivem. Este reconhecimento de que é impossível escapar da definição dos relacionamentos em termos de tais bens, não parece, para MacIntyre, incompativel com a constatação de que diferentes sociedades têm distintos códigos de honestidade, justiça e coragem.

Para MacIntyre, se de um lado a diversidade de códigos não impede o florescimento das práticas, por outro, a não valorização das virtudes pela sociedade o faz, embora possam continuar a surgir propostas unificadas de instituições e habilidades técnicas. Isto porque a cooperação, o reconhecimento de autoridade, a realização, o respeito por padrões e a assunção de riscos que estão caracteristicamente envolvidos nas práticas requerem justiça no juízo de si próprio e dos outros; honestidade desapiedada a fim de possibilitar a aplicação da justiça; 
disposição para confiar nos juízos dos que devido a suas realizações gozam dentro da prática de autoridade para julgar; justiça e honestidade nos juízos e a possibilidade de periodicamente expor a si próprio e a realização da prática a riscos.

Ingressar em uma prática é passar a se relacionar tanto com seus praticantes contemporâneos, quanto com os predecessores, especialmente com os partícipes cujas realizações expandiram seu alcance até o ponto presente. Então, o que se confronta é a autoridade de uma tradição que tem de ser aprendida. Por esta razão, a aprendizagem e o relacionamento com o passado que possibilita a corporalização das virtudes da justiça, coragem e honestidade são pré-requisitos para a manutenção das relações presentes no interior das práticas.

Não se pode deixar de ponderar, segundo MacIntyre, que onde as virtudes são exigidas, os vícios também encontram terreno fértil. Porém, os viciosos e de mauespírito necessariamente contam com as virtudes dos demais para que as práticas nas quais se engajam possam prosseguir. Ademais, negam a si próprios a experiência da realização dos bens internos.

No sentido defendido pelo autor, uma prática não configura apenas um conjunto de habilidades técnicas, ainda que estas sejam requeridas para seu exercício. O que caracteriza uma prática é como as concepções dos bens e fins relevantes aos quais as habilidades técnicas servem são transformadas e enriquecidas pelas ampliações das potencialidades humanas e pela ponderação dos próprios bens internos, que são apenas parcialmente definitivos para cada prática em particular ou para um tipo de prática específico. Os objetivos e metas de uma prática não são perenes, mas transmudados por sua história. E esta, por sua vez, transcende a melhoria das habilidades técnicas relevantes. Tal dimensão histórica é crucial para as virtudes.

Práticas e instituições não devem ser confundidas, por exemplo, física e medicina são exemplos das primeiras e laboratórios, universidades e hospitais das últimas. As instituições, caracteristicamente, preocupam-se com os bens externos, 
isto é, estão envolvidas em ganhar dinheiro e outros bens materiais, além de serem estruturadas em termos de poder e status, conferidos, juntamente com o dinheiro, como recompensas. E, pondera MacIntyre, nem poderia ser de outra maneira, uma vez que existem para sustentar não somente a si mesmas, mas às práticas das quais são portadoras sociais. Nenhuma prática é capaz de sobreviver sem o apoio de uma instituição. Na verdade, a interface destas e, conseqüentemente, dos bens externos com os internos é tal que chegam a formar uma única ordem causal na qual os ideais, a criatividade e a preocupação cooperativa pelos bens comuns da prática ficam vulneráveis à ganância e à competitividade da instituição. Neste contexto, para o autor, a função essencial das virtudes fica clara. Sem estas, ou seja, sem justiça, coragem e honestidade as práticas são incapazes de opor resistência ao poder corruptor das instituições.

Assim, a capacidade de uma prática reter sua integridade depende das possibilidades e do real exercício das virtudes na manutenção das instituições que a porta. Para ser íntegra, uma prática requer que ao menos alguns dos indivíduos que a corporificam em suas atividades exerçam as virtudes, sendo a corrupção das instituições, pelo menos em parte, efeito dos vícios. Entretanto, alerta MacIntyre, nunca é demais lembrar que é sempre dentro de alguma comunidade em particular, com suas instituições especificas que as pessoas aprendem a exercer as virtudes ou falham neste aprendizado.

A possessão das virtudes - mas não sua aparência ou simulacro - é necessária para alcançar os bens internos às práticas, podendo, contudo, tornar-se empecilho para realizar os bens externos. Estes são genuinamente bens, não apenas enquanto objetos do desejo humano, cuja alocação atende as virtudes da justiça e da generosidade, mas porque ninguém pode desprezá-los sem uma certa hipocrisia. Desta maneira, na opinião de MacIntyre, considerando as condições do mundo, não seria de se espantar que o cultivo da honestidade, da justiça e da coragem representasse um impeditivo para a riqueza, a fama ou o poder, isto é, embora seja possivel esperar realizar os padrões de excelência e os bens internos de certas práticas pela possessão das virtudes, alcançar riqueza, fama e poder pode se tornar 
impossivel com isto. Se em uma sociedade específica dominar a persecução dos bens externos, o conceito de virtude pode ficar sob o risco de um desgaste ou, até mesmo, da total extinção, apesar de suas imitações poderem ser abundantes.

Esta noção de virtude apresentada por MacIntyre, de acordo com o próprio autor, guarda semelhanças e distanciamentos da visão aristotélica das virtudes. Quanto ao último aspecto, ressalta que embora sua explanação para as virtudes seja teleológica, não guarda fidelidade à biologia metafisica de Aristóteles. Outro ponto é que não considera o conflito exclusivamente como falha do caráter individual, pois entende que há uma multiplicidade de práticas humanas e uma conseqüente diversidade de bens, muitas vezes incompativeis, na persecução dos quais as virtudes podem ser exercidas.

Em relação às semelhanças, dentre outras, destaca que esta explicação acomoda uma noção aristotélica de prazer e gozo, irreconciliável com qualquer entendimento utilitarista, pois é próprio da virtude seu exercício sem a consideração das conseqüências, a fím de ser efetiva na produção dos bens internos. Os que realizam a excelência no interior das práticas, caracteristicamente, deleitam-se com esta realização e consecução, entretanto, tal prazer não constitui fim ao qual o agente almeja, porque este resulta da atividade exitosa. Lembra o autor, que não a todo prazer corresponde o deleite que sobrevém à realização exitosa da atividade. Alguns dos prazeres configuram estados psicológicos e físicos independentes da atividade, ou seja, conformam bens externos juntamente com o prestígio, status, poder e dinheiro, podendo, como tais, serem procurados enquanto recompensas externas passiveis de serem conseguidas pelo dinheiro ou recebidas em virtude do prestígio.

Macintyre define as virtudes em termos de seu lugar nas práticas, entretanto, algumas delas, isto é, algumas atividades humanas consistentes e que se encaixam em seu entendimento de prática - são más, como alerta o próprio autor. Parece óbvio, para ele, que graças a fatos contingenciais, as práticas, em ocasiões particulares, apresentem-se como produtoras do mal. Esclarece que não pretende, com sua explanação, desculpar ou fechar os olhos ao mal que pode advir das práticas e 
tampouco quer defender que tudo quanto brote de uma virtude é certo. A coragem, às vezes, pode manter a injustiça e a lealdade pode proteger um agressor assassino. $O$ fato das virtudes terem de ser inicialmente definidas e explicadas com referência à noção de prática não significa, de maneira alguma, a aprovação de todas as práticas, em qualquer circunstância.

Em outras palavras, a definição das virtudes não em termos de práticas boas e certas, mas simplesmente de práticas não implica que estas como são desenvolvidas na realidade, em determinados tempos e lugares não necessitem de criticismo moral. E não faltam recursos para a elaboração de tal crítica, uma vez que não há inconsistência alguma em apelar para as exigências de uma virtude com o intuito de criticar sua própria prática. Uma moralidade das virtudes requer como contrapartida uma concepção de lei moral, cujos ditames também têm de ser acatados pelas práticas.

MacIntyre enfatiza que o âmbito de qualquer virtude na vida humana ultrapassa os limites das práticas em termos das quais recebe sua definição inicial, ou seja, requer-se uma noção de bem humano que transcenda a limitada compreensão das virtudes que é viabilizada pelas práticas. Isto porque uma virtude não é apenas uma propensão que colabora para o sucesso somente em algum tipo particular e específico de situação, ao contrário, o que se espera de alguém possuidor de virtudes é a manifestação destas, nas diferentes circunstâncias da vida.

Argumenta MacIntyre que se esta ampliação não ocorrer, primeiro de tudo, a vida seria invadida por excessiva conflituosidade e arbitrariedade, já que a existência de múltiplos bens abre espaço para que o conflito ocorra até mesmo na vida de uma pessoa virtuosa e disciplinada. As exigências das distintas práticas podem ser incompativeis a ponto de fazer a pessoa oscilar de maneira arbitrária, ao invés de escolher racionalmente. Se a vida das virtudes é continuamente fraturada por escolhas nas quais a fidelidade a uma acarreta a renúncia aparentemente arbitrária de outra, poderia parecer que os bens internos às práticas, afinal de contas, derivam sua autoridade de opções individuais. Segundo, a noção de certas virtudes permanece 
imparcial e incompleta enquanto não existir uma concepção mais abrangente de telos para a vida humana, pois este garantiria a subordinação de uns bens aos outros. Desta forma, o autor sugere que se não houver um telos que transcenda os bens limitados das práticas, constituindo um bem da vida humana como um todo, a vida moral pode ser invadida pela arbitrariedade e chegar à incapacidade de especificar o contexto de certas virtudes de maneira adequada. Por último, há pelo menos uma virtude reconhecida pela tradição, cuja especificação somente pode ocorrer por referência à unidade da vida humana, a virtude da integridade ou constância.

Contemporaneamente, segundo MacIntyre, qualquer tentativa de confrontar a vida humana como um todo, uma unidade cujo caráter pode prover às virtudes um telos adequado, encontra obstáculos de cunho social e filosófico. Os óbices sociais decorrem da forma como a modernidade divide a vida humana em uma variedade de segmentos, cada qual com suas próprias normas e modos de comportamento. Assim, o trabalho é separado do lazer, a vida privada da pública, a corporativa da pessoal, a infância e a velhice do resto da vida. E estas separações se configuram de tal maneira que é com base na distinção de cada uma e não na unidade da vida de um individuo que ocorrem o pensamento e o sentimento. Os obstáculos filosóficos incluem a tendência de pensar a ação humana atomisticamente, analisando atividades e transações complexas em termos de componentes simples.

As virtudes, portanto, a partir desta expansão em sua concepção proposta pelo autor, constituem disposições que não apenas mantêm práticas e capacitam para a realização dos bens internos a estas, mas sustentam um relevante tipo de expedição para o bem, por possibilitar a superação das ofensas, prejuízos, perigos, tentações e perturbações divisadas, proporcionando um crescente autoconhecimento e cognição do bem. O catálogo de virtudes, desta maneira, abarca as requeridas para manter o tipo de famílias e comunidades políticas nas quais homens e mulheres possam juntos procurar pelo bem.

Por isto, na visão de MacIntyre, é impossível ser capaz de procurar pelo bem ou exercitar as virtudes apenas enquanto individuo. $E$ isto ocorre em parte porque o 
entendimento de vida "boa" varia segundo o tempo histórico e o local, ou seja, o que é considerado vida boa por um ateniense do século $\mathrm{V}$ difere da visão de uma freira medieval ou de um agricultor do século XVII. Entretanto, não é somente que estes diferentes individuos vivem em distintas realidades sociais, mas cada um aborda sua própria circunstância enquanto portador de uma identidade social em particular, isto é, cada qual é filho ou filha de alguém, primo ou tio de outro mais, cidadão desta ou daquela cidade, membro desta ou daquela corporação ou profissão, pertencente a este clã, aquela tribo, esta nação. Como tal, herda do passado da família, da cidade, da tribo, da nação uma variedade de dívidas, patrimônios, expectativas e obrigações legitimas que constituem o dado de uma vida, seu ponto de partida moral.

A história da vida de uma pessoa está sempre incrustada na história das comunidades das quais ela deriva sua identidade. Cada qual nasce com um passado e tentar dele se desligar, no modo individualista, significa deformar as relações presentes. As possessões de uma identidade histórica e de uma identidade social coincidem. É claro que este pensamento, alerta o autor, é estranho e mesmo surpreendente do ponto de vista do individualismo moderno, defensor de que cada um pode ser o que escolher, com os aspectos históricos e sociais passando a representar meros traços contingenciais de sua existência.

Macintyre ressalta que o fato da identidade moral ser forjada na pertença às comunidades, como a família, vizinhança, cidade, tribo, dentre outras, não significa que tem que aceitar as limitações morais advindas das particularidades destas formas de comunidade. Se por um lado sem tais particularidades morais fica impossibilitada a constituição de um ponto de partida moral, por outro, é movendo-se para além delas que a procura pelo bem, pelo universal se concretiza. Ainda assim, a particularidade nunca pode ser simplesmente deixada para trás ou obliterada. $\mathrm{O}$ autor considera que a noção de escapar das particularidades para um reino inteiramente de máximas universais que pertencem ao humano como tal conforma uma ilusão com conseqüências dolorosas. 
O que cada um é, portanto, consiste, em grande parte, no que se herda, ou seja, existe no presente, em algum grau, um passado específico. Cada qual toma parte de uma história e isto significa, para o autor, que, goste-se ou não, reconheça-se ou não, cada um é portador de uma tradição. E o que mantém e fortalece as tradições ou as enfraquece e destrói é, em grande medida, o exercício das virtudes ou a falta deste, respectivamente. A falta de justiça, honestidade, coragem e virtudes intelectuais corrompe tradições, assim como as instituições e práticas que são suas portadoras sociais contemporâneas.

Quando o autor caracteriza o conceito de prática é importante notar, como ele próprio destaca, que estas têm histórias e que em qualquer momento o que uma prática é depende do modo de entendê-la, transmitido, freqüentemente, através das gerações. $\mathrm{E}$ as tradições através das quais as práticas particulares são passadas $\mathrm{e}$ remodeladas não existem isoladamente das tradições sociais mais amplas.

Parece ficar claro, então, como salienta o próprio MacIntyre, que sua concepção das virtudes prossegue através de três estágios: o primeiro que diz respeito às virtudes enquanto qualidades necessárias para realizar bens internos às práticas; o segundo que as considera como qualidades contribuintes para o bem de toda uma vida e o terceiro que as relaciona à persecução de um bem para os seres humanos, cuja noção somente pode ser elaborada e apropriada dentro de uma contínua tradição social.

A menos que satisfaça as condições especificadas em cada um dos três estágios, uma qualidade humana não pode ser considerada uma virtude. Isto é importante porque há qualidades que, mesmo decorrendo de práticas, não são virtudes, pois sobrevivem aos testes do primeiro estágio e falham no segundo ou terceiro.

Para exemplificar situações deste tipo, MacIntyre considera as qualidades da impiedade e rigidez, distinguindo-as da qualidade sábia de reconhecer quando ser impiedoso e rígido. Há práticas, como a exploração do estado selvagem, nas quais a 
habilidade para ser impiedoso e rígido em guiar a si próprio e aos outros pode ser uma condição não apenas para alcançar bens, mas para sobreviver. Tal habilidade pode requerer como condição para seu exercício o cultivo de certa insensibilidade para com os sentimentos dos outros, uma vez que levar isto em conta pode resultar em preocupações com a sobrevivência. A transposição deste complexo de qualidades para a prática de estabelecer e manter a vida de uma família perfaz a receita para um desastre, isto é, o que parecia ser uma virtude em um contexto, torna-se um vício em outro. Mas, estas qualidades não configuram, para o autor, nem uma virtude nem um vício. Não são virtudes porque se mostram incapazes de satisfazer a exigência de que uma virtude tem de contribuir para o bem da vida humana como um todo, uma unidade na qual os bens de práticas particulares se integram em um padrão total de objetivos que responde a questão acerca de qual é o melhor tipo de vida para um ser humano levar.

MacIntyre considera que uma dificuldade, dentre muitas a serem enfrentadas por sua noção de virtude, é que o tipo de trabalho feito pela maioria dos habitantes do mundo moderno não pode ser entendido em termos da natureza de uma prática com bens internos. Um dos momentos chave na criação da modernidade ocorre quando a produção se desloca para fora da família e coloca-se a serviço do capital impessoal. Isto faz com que o trabalho, além de ser apartado do reino das práticas com bens internos a elas próprias, vincule-se à busca da sobrevivência biológica e da reprodução da força de trabalho de um lado e à ganância institucionalizada do outro, com relações meios-fins necessariamente externas. Conseqüentemente, as práticas são removidas para as margens da vida social e cultural.

\subsection{O ENFOQUE DO CUIDADO: A ÊNFASE NAS RELAÇÕES}

No desenvolvimento da noção de cuidado têm concorrido ao longo da história várias abordagens, como a mitológica, religiosa, filosófica, psicológica e teológica que acabam por influir orientações éticas e comportamentos morais. Disto decorrem 
distintas estruturas explicativas para a ética do cuidado, incluindo sua compreensão como ética evolucionária, ética da virtude, ética do desenvolvimento, ética da responsabilidade e ética do dever. Estas explanações revelam que não há uma idéia única de cuidado, mas um conjunto de noções de cuidado que se unem por alguns sentimentos básicos, algumas narrativas formativas cuja influência perdura através dos tempos e de diversos temas recorrentes.

Uma das concepções de cunho psicológico que goza de grande destaque é a proposta de Carol Gilligan, contida em seu livro In a different voice: psychological theory and women's development, editado em 1982. Em sua obra, trata da interface da teoria psicológica e do desenvolvimento psicológico das mulheres, criticando o caráter prescritivo atribuído à primeira. Com base em dados de estudos empíricos, reconstrói o desenvolvimento psicológico das mulheres a partir do entendimento de que este está centrado em uma batalha por conexão, negando, assim, a visão corrente, defendida por vários teóricos da psicologia, que considera as mulheres defectivas em seu desenvolvimento moral por não alcançarem a separação.

Ao abordar a perspectiva do cuidado no desenvolvimento moral das mulheres, uma ética do cuidado emerge, questionando as concepções éticas vigentes e apontando novos rumos para a bioética, com vistas a valorizar não apenas os atos, as motivações e o caráter dos envolvidos, mas se as relações positivas são ou não favorecidas (REICH 1995b; BEAUCHAMP e CHILDRESS 1999).

É comum, desde então, trabalhos contrastando a visão ética com base nos princípios ou direitos individuais, conhecida como ética da justiça, e a ética do cuidado (TONG 1998):

\begin{tabular}{ll}
\hline \multicolumn{1}{c}{ Ética do cuidado } & \multicolumn{1}{c}{ Ética da justiça } \\
\hline Abordagem contextual & Abordagem abstrata \\
Conexão humana & Separação humana \\
Relacionamentos comunitários & Direitos individuais \\
Âmbito privado & Âmbito público \\
Reforça o papel das emoções & Reforça o papel da razão \\
É relativa ao gênero feminino & É relativa ao gênero masculino \\
\hline
\end{tabular}


Para explorar este referencial teórico, então, seleciona-se uma reimpressão do livro In a different voice: psychological theory and women's development, que é lançada pela primeira vez em 1993. Esta versão amplia a original com a introdução de um prefácio contendo uma "carta aos leitores", na qual Carol Gilligan esclarece seus objetivos com a obra e responde a algumas das críticas que seu trabalho recebeu neste periodo (GILLIGAN 1998).

Ao abrir esta carta, a autora assinala que a época quando começa a escrever o livro, início de 1970, é marcada pelo ressurgimento do Movimento das Mulheres e por um fato relevante para a sociedade norte-americana: a decisão da Suprema Corte do país de tornar o aborto legalmente disponivel, no caso Roe $v$. Wade ${ }^{13}$. Com isto, as bases das relações entre homens, mulheres e crianças são expostas. Ressalta que quando a mais alta corte judicial dos EUA torna legal para a mulher falar por si própria e outorga-lhe a voz de decisão em um problema complexo de relacionamento que envolve responsabilidade pela vida e pela morte, muitas se dão conta da força de uma voz interna que interfere em sua habilidade para se expressar. Esta voz interna ou internalizada diz à mulher que ela pode ser egoísta, trazer sua visão para as relações; que ela não sabe o que realmente quer ou ainda que sua experiência não constitui diretriz confiável para pensar sobre o que fazer, ou seja, as mulheres consideram perigoso dizer, ou mesmo saber, o que querem ou pensam, pois podem se indispor com os outros, configurando-se, assim, uma ameaça de abandono ou retaliação.

Muitas mulheres, então, sob a intimidação dos temores representados por estas ameaças, pensam ser melhor parecer "desprendidas" e abrir mão de suas vozes para ficarem em paz. Esta escolha pode ser deliberada ou involuntária e, freqüentemente, apesar de bem intencionada, psicologicamente protetora e motivada

\footnotetext{
${ }^{13}$ Este caso integra uma série de decisões da Suprema Corte dos EUA emitidas durante uma década cercada de considerável confusão legal acerca do tema do aborto. Nesta sentença, a Corte sustenta o direito da mulher grávida interromper a gestação dentro de limites, abolindo a estrutura do trimestre. Reconhece o interesse do Estado na vida fetal desde o início da gravidez e permite aos Estados norteamericanos instituir exigências que não imponham uma carga indevida sobre as decisões e ações da mulher grávida, embora não confirme a obrigação do Estado suprir meios e assistência para a realização de abortos não terapêuticos. (BEAUCHAMP E CHILDRESS, 2001).
} 
por preocupações para com os sentimentos das pessoas, acabam perpetuando uma civilização de vozes masculinas e uma ordem de viver fundada na desconexão (p. $x$ ). Por isto, Gilligan considera revolucionária a descoberta das mulheres que ser desprendida significa não estar em relacionamento, pois desafiam a desconexão e dissociação mantidas pela sociedade patriarcal.

A autora salienta que na medida em que continua a explorar as conexões entre a ordem política e a psicologia da vida das mulheres e dos homens, fica-lhe gradativamente mais claro o papel crucial das vozes das primeiras na manutenção ou transformação do mundo patriarcal. Ao se envolver ativamente neste processo de mudança, vê a si própria e a seu livro, no centro de um debate no qual estão em questão a sanidade e o poder.

Ouvindo as reações das pessoas a seu livro, Gilligan lamenta como a forma diferente das mulheres falarem é prontamente assimilada em velhas categorias do pensamento, perdendo sua novidade e sendo colocada em questões acerca de quem seria melhor ou pior, as mulheres ou os homens. Ressalta que, quando escuta seu trabalho sendo discutido nestes termos - se as mulheres e os homens são realmente diferentes ou quem é melhor - sabe que não foi bem compreendida, porque não são estas as questões que deseja fazer emergir. Ao invés disso, suas questões são sobre as percepções da realidade e da verdade; sobre voz e relacionamentos e sobre processos e teorias psicológicas nas quais as experiências dos homens constituem a base para a totalidade da experiência humana, eclipsando a vida das mulheres e calando suas vozes.

Quando esta voz diferente resiste, configurando uma voz relacional, uma voz que insiste em ficar em conexão, as separações psicológicas que tomam por base a autonomia, a personalidade e a liberdade não aparecem mais como uma condição sine qua non do desenvolvimento humano. Ressalta a autora que, dentro do contexto de sociedades como a norte-americana, articular esta voz distinta pode equiparar-se a questionar o valor da liberdade, pois os valores de separação, independência e autonomia são tão historicamente fundamentados, reafirmados e enraizados na 
tradição dos direitos naturais que, freqüentemente, são tomados como fatos, ou seja, por natureza as pessoas são separadas, independentes e autogovernadas.

Encontram-se no fulcro de seus escritos, esclarece Gilligan, questões sobre voz, diferença e desenvolvimento de mulheres e homens. Quanto à voz, entende que ter uma voz é ser humano, ou seja, ter algo a dizer é ser uma pessoa. Também por voz, a autora explica, quer expressar o que as pessoas significam quando falam do âmago do eu. Voz é natural e cultural, porque composta de respiração, som, palavras, ritmos e linguagem. Configura um poderoso instrumento e canal psicológico, conectando os mundos externo e interno. Falar depende de escutar e ser ouvido, constituindo um ato intensamente relacional, uma relação mútua de troca entre as pessoas, mediada pela linguagem, cultura, diversidade e pluralidade. Por estas razões, considera a voz como uma nova chave para a compreensão da ordem psicológica, social e cultural.

No que diz respeito à diferença, Gilligan esclarece que tenta deslocar esta discussão do foco do relativismo para os relacionamentos, entendendo as diferenças enquanto marcas próprias da condição humana e não como problema a ser resolvido. Entretanto, alerta que ao falar sobre diferenças e suas conseqüentes teorizações há de se estar atento para a rapidez com que a diferença torna-se desvio e este adquire quase um tom de "pecado" em uma sociedade preocupada com a normalidade, escrava da estatística e historicamente puritana.

A autora reputa perturbadoras as discussões que abordam se as diferenças de gênero são biologicamente determinadas ou socialmente construídas, pois, na sua opinião, esta maneira de apresentar a questão implica que as pessoas - homens e mulheres - são ou geneticamente determinadas ou um produto da socialização, não restando possibilidade alguma para a resistência, a criatividade ou a mudança, cujas fontes são psicológicas. Para ela, a presente redução da psicologia na sociologia, na biologia ou numa combinação de ambas prepara o caminho para uma espécie de controle que sufoca a voz e provoca a morte da linguagem, possibilitando irromper as condições para o totalitarismo. 
Os problemas éticos conformam problemas de relações humanas e, ao traçar o desenvolvimento de uma ética do cuidado, Gilligan explora os fundamentos psicológicos para as relações humanas não violentas. Esta ética relacional transcende a oposição entre egoísmo e desprendimento que tem sido o elemento principal da linguagem ética. A procura por uma voz que supere tal dicotomia representa uma tentativa de mudar o foco da discussão ética das questões acerca de como alcançar objetividade e distanciamento, para às relativas a como se engajar em relacionamentos com responsabilidade e cuidado.

Relacionamento requer conexão e depende tanto da capacidade para a empatia ou da habilidade de ouvir os outros a fim de aprender sua linguagem ou seu ponto de vista, quanto de ter uma voz, uma linguagem. As diferenças entre as mulheres e os homens, descritas pela autora, centram-se na tendência de ambos cometerem diferentes erros relacionais: os últimos pensando que ao conhecerem a si próprios, conseqüentemente, conhecem as mulheres e estas entendendo que somente por conhecerem os outros, conhecerão a si próprias. Então, os homens e as mulheres, tacitamente, tramam ao não darem voz para as experiências das mulheres $\mathrm{e}$ construírem relacionamentos baseados no silêncio que é mantido pela dupla falta de percepção de seus erros relacionais: os homens com sua desconexão das mulheres e estas com sua dissociação de si mesmas.

A este equívoco nos relacionamentos, de acordo com Gilligan, juntam-se os enganos nas teorias psicológicas que têm tomado os homens como únicos representantes dos humanos, fazendo com que as mulheres, em seu desenvolvimento psicológico, empenhem-se em alterar suas vozes para se encaixarem nas imagens de relacionamento e bondade construídas a partir de falseadas vozes femininas.

Ao contrapor este entendimento do desenvolvimento psicológico das mulheres com as teorias do desenvolvimento humano que, na verdade, configuram teorias sobre os homens, Gilligan elabora sua proposta de trabalho: que a crise relacional experimentada pelos homens, geralmente no início da infância, para as 
mulheres ocorre na adolescência e envolve, tanto para os meninos quanto para as meninas, uma desconexão das mulheres que é essencial para a manutenção das sociedades patriarcais. A resistência das meninas a separações culturalmente mandadas em uma época posterior de seu desenvolvimento confere maior articulação e robustez a sua relutância, que, encontrando eco nos desejos de homens e mulheres por relacionamentos, levanta novas possibilidades de relações e maneiras de viver.

Neste sentido, a autora considera inevitável o desafio que representa para a ordem patriarcal perpetuada pelo eclipse contínuo da experiência feminina, uma nova teoria psicológica na qual as meninas e mulheres sejam vistas e ouvidas. Assim, ficar em conexão com elas no ensino, na pesquisa, na terapia, na amizade, na maternidade ou no curso de sua vida diária, trazendo à luz suas vivências, é potencialmente revolucionário.

É com a intenção de trazer as vozes das mulheres para a teoria psicológica e de reformular a conversa entre estas e os homens que Carol Gilligan escreve sua obra, cuja publicação the permite, com surpresa como confessa, descobrir que sua experiência ressoa com a de outras mulheres e também, de diversas maneiras, com a dos homens.

Seu objetivo, como o delimita, é ampliar a compreensão do desenvolvimento humano através da inclusão do grupo deixado de fora na construção das teorias, o das meninas e mulheres, com a finalidade de chamar a atenção para os pontos faltantes em seu enfoque. A partir desta perspectiva, os dados discrepantes sobre a experiência feminina propiciam uma base sobre a qual se origina uma nova teoria, potencialmente produtora de uma visão mais abrangente da vida dos homens e das mulheres. 


\subsubsection{O RECONHECIMENTO DE UMA VOZ DIFERENTE}

Nos dez anos que precedem o lançamento de In a different voice em 1982, Gilligan escuta as pessoas falarem sobre moralidade e si próprias e em determinado momento desta trajetória, começa a ouvir uma distinção nas vozes: duas maneiras de falar sobre os problemas éticos; dois modos de relatar o relacionamento entre o outro e o eu.

São estas maneiras diferentes de pensar sobre os relacionamentos e sua associação com vozes masculinas e femininas nos textos psicológicos, literários e nos dados das pesquisas da autora que se encontram registradas no livro. A disparidade existente entre as experiências das mulheres e a representação do desenvolvimento humano descrita na literatura psicológica, geralmente, é tomada como um problema de desenvolvimento deste grupo. Acostumados a ver a vida através dos olhos dos homens, os teóricos da psicologia cometem, segundo Gilligan, um viés de observação, implicitamente adotando a vida masculina como a norma e tentando a ela moldar a mulher, que então é vista como desviante, quando comparada ao padrão masculino.

Contrariando esta visão, a autora propõe que ao invés da falha das mulheres para se encaixarem em modelos existentes do desenvolvimento moral humano o que pode estar ocorrendo é um problema na representação, uma limitação na concepção da condição humana, uma omissão de certas verdades sobre a vida.

A associação desta voz diferente com as mulheres corresponde à descrição de uma observação empírica, ou seja, é primariamente através das vozes das mulheres que se traça seu desenvolvimento. Entretanto, alerta a autora, ela não se caracteriza pelo gênero, mas pelo tema, sendo os contrastes entre as vozes masculinas e femininas apresentados na obra prestam-se mais para aclarar uma diferenciação entre dois modos de pensar e focalizar um problema de interpretação do que para representar uma generalização sobre qualquer dos gêneros. 
Para a autora, graças as suas diferentes visões acerca do eu e da moralidade, as mulheres trazem para o ciclo da vida um ponto de vista díspar e ordenam a experiência de vida em termos de distintas prioridades. Para elas, o problema ético origina-se de responsabilidades conflitantes e não de direitos competidores, requerendo para sua resolução um modo de pensar contextual e narrativo no lugar do formal e abstrato. Por sua preocupação com a atividade de 'tomar conta', centram seu desenvolvimento moral em torno da compreensão da responsabilidade e dos relacionamentos, contrapondo-se à concepção voltada para a justiça, que vincula o desenvolvimento moral ao entendimento de direitos e regras.

Segundo Gilligan, como as mulheres percebem a agressão vinculada a uma ruptura da conexão humana, as atividades de cuidado são as que fazem o mundo social seguro, evitando o isolamento e prevenindo a agressão e, portanto, não correspondem à mera enunciação de regras que limitem a abrangência dos atos agressivos. Nesta perspectiva, a agressão deixa de ser entendida como um impulso incontrolável que deve ser contido, para ser vista como um sinal de ruptura na conexão, de falha no relacionamento. As mulheres tendem a mudar as regras a fim de preservar os relacionamentos, enquanto os homens, acatando-as, descrevem as relações como facilmente substituíveis. O ideal do cuidado consiste, então, em uma atividade de relacionamento, de perceber e responder às necessidades, de tomar conta do mundo buscando a manutenção da teia de conexão de modo que ninguém seja deixado sozinho.

O mundo das mulheres é formado por relacionamentos e verdades psicológicas, no qual a consciência da conexão entre as pessoas leva ao reconhecimento da responsabilidade de uns pelos outros e à percepção da necessidade de resposta. Ao tomar a moralidade como resultante do reconhecimento do relacionamento; ao acreditar que a comunicação é o modo de solucionar os conflitos e ao ter a convicção de que a chave para a solução do dilema está na forma de sua representação, longe de ser ingênuo ou cognitivamente imaturo, o juízo das mulheres contém as compreensões decisivas para uma ética do cuidado, em contraste com a lógica da abordagem da justiça. O princípio central da resolução não-violenta 
de conflitos e a crença na atividade restauradora do cuidado fazem com que os atores de um dilema sejam vistos não como adversários em uma pendência de direitos, mas como membros entrelaçados de uma rede de relacionamentos, de cuja continuidade todos dependem. Conseqüentemente, a resolução para um problema ético consiste em ativar esta rede de relacionamentos pela comunicação, garantindo a inclusão de todos mediante o fortalecimento, ao invés do rompimento das conexões.

\subsubsection{CONCEITOS DE EU E MORALIDADE}

A elaboração das questões éticas como problemas de cuidado e responsabilidade nos relacionamentos, e não enquanto problemas de direitos e normas, liga o desenvolvimento moral das mulheres às mudanças em seu entendimento de responsabilidade e relacionamentos, da mesma maneira que a concepção de moralidade pautada pela justiça une-o à lógica da igualdade e reciprocidade. Assim, ressalta Gilligan, subjaz à ética do cuidado uma lógica psicológica dos relacionamentos, em contraposição à formal de igualdade que dá corpo ao enfoque da justiça.

As três perspectivas reveladas pelos estudos da autora denotam uma seqüência no desenvolvimento da ética do cuidado. As diferentes visões de cuidado e a transição entre elas emergem da análise de como as mulheres usam a linguagem moral; de como refletem e julgam seu pensamento e das mudanças e modificações que nele aparecem.

Na seqüência observada e descrita por Gilligan, um foco inicial no cuidado do eu, com vistas a assegurar a sobrevivência, é seguido por uma fase de transição na qual se critica este primeiro juízo como egoísta. O criticismo assinala um novo entendimento da conexão entre o eu e o outro, articulada pelo conceito de responsabilidade. A elaboração desta concepção de responsabilidade e sua fusão com uma moralidade materna, que busca garantir o cuidado dos dependentes e desiguais caracterizam a segunda perspectiva. Neste ponto, o bom equipara-se ao cuidar dos outros. Entretanto, quando a mulher se exclui e reconhece apenas os outros como 
receptores legítimos de seus cuidados, geram-se problemas nos relacionamentos e cria-se um desequilíbrio que redunda na segunda transição. Num esforço para desfazer a confusão entre auto-sacrificio e cuidado, inerente às convenções da bondade feminina, tem lugar uma reconsideração das relações com base no questionamento da equiparação entre conformismo e cuidado, presente nas definições convencionais e na falta de lógica existente na desigualdade entre o outro e o eu. A terceira perspectiva focaliza a dinâmica dos relacionamentos e dissipa a tensão entre egoísmo e responsabilidade com um novo entendimento da interconexão do outro e do eu. O cuidado torna-se o princípio auto-escolhido de um juízo que continua psicológico em sua preocupação com os relacionamentos e as respostas, mas se abre ao universal, em sua condenação da exploração e do sofrimento.

Então, uma compreensão progressivamente mais adequada da psicologia dos relacionamentos humanos, com uma diferenciação cada vez maior do eu e do outro e uma crescente compreensão da dinâmica da interação social, corporificam o desenvolvimento de uma ética do cuidado. Esta reflete um conhecimento cumulativo das relações humanas e desdobra-se em torno de um discernimento central: a interdependência do eu e do outro. As diferentes maneiras de pensar sobre esta conexão ou os distintos modos de apreendê-la marcam as três perspectivas e suas fases de transição. Nesta seqüência, salienta Gilligan, a premissa da interconexão dá forma ao reconhecimento central e recorrente de que a violência, no fim, é destrutiva para todos, da mesma maneira que a atividade do cuidado robustece tanto o outro quanto o eu.

A fim de ser capaz de cuidar do outro, deve-se primeiro ser capaz de cuidar responsavelmente de si mesmo. O desenvolvimento da infância para a idade adulta é concebido como o movimento do egoísmo para a responsabilidade. Neste sentido, a autora alerta, que o auto-sacrificio retarda e milita contra o auto-desenvolvimento das mulheres, sendo este um dever mais elevado que o primeiro.

Admitir a verdade da perspectiva feminina na concepção do desenvolvimento moral implica reconhecer, tanto para as mulheres quanto para os homens, a 
importância da conexão entre o eu e o outro e a universalidade da necessidade de compaixão e cuidado. O imperativo moral que emerge das entrevistas com as mulheres é uma injunção para cuidar, uma responsabilidade de discernir e mitigar o problema real do mundo. Para os homens, o imperativo moral aparece mais como uma obrigação de respeitar os direitos dos outros e proteger contra interferências os direitos à vida e à auto-realização. $\mathrm{Na}$ voz diferente das mulheres, subjaz a expressão de uma ética do cuidado, do vínculo entre relacionamento e responsabilidade e a visão da agressão como falha nesta conexão. A moralidade dos direitos (ética da justiça) fundamenta-se na igualdade e centra-se no entendimento da justiça, configurando uma manifestação de igual respeito e contra-balançando as reivindicações do outro e do eu. A moralidade da responsabilidade (ética do cuidado) tem por base o conceito de eqüidade, de reconhecimento das diferenças nas necessidades, apoiando-se numa compreensão que dá origem à compaixão e ao cuidado.

Portanto, de acordo com Gilligan, o desenvolvimento, para os dois gêneros, propicia uma integração de direitos e responsabilidades através da descoberta da complementaridade dessas visões díspares. Para as mulheres, a integração de direitos e responsabilidades ocorre através do entendimento da lógica psicológica dos relacionamentos, resultando na moderação do potencial autodestrutivo de uma moralidade autocrítica ao universalizar a necessidade de cuidado. Para os homens, o reconhecimento da responsabilidade do cuidado corrige a latente indiferença de uma moralidade de não-interferência e volta a atenção da lógica para as conseqüências da escolha. Em uma compreensão pós-convencional da ética, as mulheres chegam a ver a violência inerente à desigualdade e os homens a perceber as limitações de uma concepção de justiça míope para as diferenças da vida humana.

Em resumo, para a autora, as mulheres imprimem uma construção distintiva para os problemas morais, vendo-os em termos de responsabilidades conflitantes. Esta construção desenvolve-se através de uma seqüência consistente de pensamentos e sentimentos com três perspectivas, cada qual representando maior complexidade no entendimento do relacionamento entre o eu e o outro e cada transição envolvendo 
uma reinterpretação crítica do conflito entre egoísmo e responsabilidade. A seqüência do juizo moral das mulheres começa com uma preocupação inicial pela sobrevivência, segue em direção à bondade que estigmatiza a primeira inquietação como egoísta e contraposta à responsabilidade de uma vida vivida nos relacionamentos para, finalmente, alcançar uma compreensão reflexiva do cuidado enquanto a diretriz mais adequada para a resolução dos conflitos nas relações humanas, percebendo que o eu e o outro são interdependentes e a vida, embora valiosa em si, só pode ser mantida pelo cuidado nos relacionamentos.

Segundo Gilligan, na conformação do reino moral das mulheres registra-se a centralidade das concepções de responsabilidade e cuidado, havendo uma ligação estreita em seu pensamento das noções do eu e moralidade. Além disto, deixa patente a necessidade de uma teoria de desenvolvimento moral mais abrangente que inclua as diferenças da voz feminina, ao invés de eliminá-la como desviante. Tal inclusão, na visão da autora, é essencial tanto para explicar o desenvolvimento das mulheres, quanto para compreender, nos dois gêneros, as características e os precursores da concepção adulta de moralidade.

Isto porque, compreender como a tensão entre responsabilidades e direitos mantém a dialética do desenvolvimento humano significa visualizar a íntegra de duas maneiras díspares de experiência que são, ao final, conectadas. Uma ética da justiça que decorre da premissa da igualdade e defende que todo mundo deve ser tratado igualmente e uma ética do cuidado que, partindo da idéia de não-violência, advoga que ninguém deveria ser ferido ou injuriado. Na representação da maturidade, ambas perspectivas convergem na percepção de que a desigualdade, adversamente, afeta todas as partes em um relacionamento e que a violência é destrutiva para os envolvidos. 


\title{
4.4 O ENFOQUE DA CASUÍSTICA: A ÊNFASE NOS CASOS CLÍNICOS
}

\begin{abstract}
Albert Jonsen e Stephen Toulmin na obra publicada em 1988, The abuse of casuistry: a history of moral reasoning, (JONSEN e TOULMIN 1988) fazem um resgate da história da casuística, desde suas origens na filosofia greco-romana e no judaísmo até o cristianismo católico. Segundo os autores, a finalidade do livro é recuperar a validez da casuística para a discussão de problemas éticos, ou seja, pretendem reabilitar a "arte da casuística" como a "resolução prática de perplexidades morais ou casos de consciência" (JONSEN e TOULMIN 1988, p. 13).
\end{abstract}

Como pressupostos essenciais para a compreensão de sua obra, os autores incluem: a distinção das formas possíveis de tratar problemas éticos; a delimitação do campo do conhecimento humano ao qual pertencem a ética e a prática clínica e a relação entre a resolução de problemas éticos e a prática clínica.

Assim, distinguem duas formas de discutir problemas éticos: uma que os ordena em termos de princípios, regras e outras idéias gerais e outra centrada nas características específicas de tipos particulares de casos. Na primeira, as regras éticas gerais relacionam-se aos casos especificos de uma maneira teórica, com regras universais servindo como "axiomas" dos quais os juízos éticos particulares são deduzidos como teoremas. Na segunda, a relação entre as regras e os problemas é francamente prática. As regras éticas gerais servem como "máximas", as quais podem ser totalmente compreendidas somente em termos dos casos paradigmáticos que definem seu sentido e sua força (JONSEN e TOULMIN 1988, p. 23).

Para os filósofos da Atenas clássica, como explicam os autores, uma opinião poderia ser aceita como conhecimento ou como um argumento sólido e verdadeiro apenas se estivesse necessariamente relacionado de maneira dedutiva a princípios iniciais claros e óbvios. Porém, Aristóteles advoga que nem todos os conhecimentos 
são desse tipo e que tampouco há esse tipo de certeza teórica em todos os campos. No campo da prática, no qual o filósofo inclui a ética, a certeza não requer domínio prévio das definições, princípios gerais e axiomas como no campo da teoria, cujo protótipo de raciocinio é a geometria. Ao contrário, depende da experiência prática acumulada de situações particulares da qual resulta um tipo de sabedoria - phronesis - diferente da que decorre do domínio abstrato de qualquer ciência teórica, a episteme.

No campo teórico, os argumentos gozam de sentido formal e são idealizados $^{14}$, atemporais ${ }^{15}$, necessários ${ }^{16}$, conformando cadeias de prova, de proposições interligadas para garantir uma conclusão. Os argumentos práticos diferem dos teóricos porque são $\operatorname{concretos}^{17}$, temporais ${ }^{18}$, presuntivos $^{19}$. De sentido substancial, configuram métodos para resolver problemas, uma rede de considerações apresentada para a solução de um dilema prático, cujo poder depende do quanto as presentes circunstâncias se assemelham as dos casos precedentes para os quais esse tipo particular de argumento foi originalmente construído.

Para Jonsen e Toulmin, recolocar a ética no campo da sabedoria prática traz implicações procedimentais no manejo da solução de problemas desta ordem, ficando estabelecido como passo necessário a identificação da situação na qual o ato em questão ocorre. Outra conseqüência é que os argumentos éticos são retóricos, não no sentido fraudulento, prejudicial ou enganador, mas de assegurar que sua

\footnotetext{
${ }^{14}$ Os objetos fisicos concretos nunca podem ser feitos com uma perfeita precisão, como cortar o metal em triângulos ou círculos perfeitos (JONSEN e TOULMIN 1988, p. 27).

${ }^{15}$ Serão verdades em qualquer tempo e em qualquer ocasião (JONSEN e TOULMIN 1988, p. 27).

${ }^{16}$ Os argumentos teóricos são estruturados de forma a libera-los de qualquer dependência das circunstâncias nas quais são apresentados e a assegurar-lhes um tipo de validade que não é afetada pelo contexto prático de uso (JONSEN e TOULMIN 1988, p. 34).

${ }_{17}$ A verdade das proposições práticas baseia-se na experiência direta. Ao invés de visar vínculos estritos, recorrem aos resultados de experiências prévias e as reaplicam nas novas situações problemáticas (JONSEN e TOULMIN 1988, p. 27 e p. 35).

${ }^{18} \mathrm{~A}$ mesma experiência que ensina o que é normalmente o caso a qualquer tempo também mostra o que é o caso somente algumas vezes. Às verdades da experiência prática, então, não se aplicam as expressões "universalmente" ou "a qualquer tempo", mas "na ocasião" ou "nesse ou naquele momento", isto é, usualmente, freqüente, quase sempre (JONSEN e TOULMIN 1988, p. 27).

${ }^{19}$ A conclusão permite refutação. As conclusões presuntivas estão, na verdade, abertas às duvidas (JONSEN e TOULMIN 1988, p. 27).
} 
explicação seja efetiva, inteligivel, capaz para causar interesse nos ouvintes e darlhes base, fundamentando-se em verdades gerais tidas como convincentes.

A prática clínica, na visão dos autores, participa da ênfase no tipo de certeza da experiência direta que marca o campo do conhecimento prático. Afirmam que, a bem da verdade, a medicina mescla, a sua própria maneira, teoria e prática, compreensão intelectual e habilidades técnicas, episteme e phronesis.

$\mathrm{Na}$ prática clínica, a questão central para o profissional é que condição específica está afetando um determinado paciente em particular e o que deve se fazer para dar dela conta, nesse exato momento e lugar. O diagnóstico clínico tem, então, seu ponto inicial no repertório corrente de doenças, injúrias e incapacidades para os quais existe descrição na literatura médica. $\mathrm{Na}$ medida em que novos casos apresentam-se para exame, o médico colhe detalhes da história, faz sua observação imediata e dos resultados dos testes diagnósticos, usando estes fatos para localizar a condição peculiar do paciente em um ou mais dos tipos reconhecidos. Forçado a escolher entre as alternativas diagnósticas, deve decidir quão perto ou análogo o caso presente está de cada uma das possibilidades.

Desta forma, as relações entre uma conclusão diagnóstica e as evidências que lhe dão suporte são mais próprias do raciocínio prático do que da prova teórica. Isto porque, a conclusão está mais relacionada às evidências substantivas do que a conexões formais. Aproxima-se mais de uma presunção refutável do que de um vínculo necessário, sendo que a inferência das evidências para a conclusão é circunstancial, pois depende de fatos detalhados sobre as condições e a natureza de um caso particular. Por essa razão, pode-se dizer que as conclusões diagnósticas são tentativas e estão abertas à reconsideração, se certos sintomas cruciais ou circunstâncias forem sobrelevados ou se o curso posterior da doença trouxer à luz novas evidências importantes.

Neste sentido, a prática clínica pode se apresentar como um modelo para a análise de problemas éticos, pois, da mesma forma que os juízos clínicos não podem 
ser isolados das condições reais de pacientes individuais, o juízo ético não pode ser abstraido das circunstâncias concretas e detalhadas dos casos práticos. Assim, a exemplo das inferências clínicas, as conclusões no campo da ética não são necessárias e não podem ser tomadas à revelia do contexto, sendo presumiveis e revisáveis à luz da experiência posterior. Em ambos os campos, o melhor a ser feito é apreciar a situação particular, trazendo a ela o maior grau de percepção clínica possível.

\subsubsection{CASUÍSTICA: ELEMENTOS E CONCEITUAÇÃO}

Como explicam Jonsen e Toulmin, é a partir de sua própria execução que o método da casuística é inferido, uma vez que os casuístas não formulam explicitamente uma metodologia, ou seja, apenas um estudo da prática real pode revelar os passos que seguem. Assim, da leitura dos casos tal qual arranjados pelos casuístas, seis passos são identificados pelos autores como dignos de nota para a compreensão deste método: a confiança nos paradigmas e analogias; o apelo às máximas; a análise das circunstâncias; os graus de probabilidade; o uso de argumentos cumulativos e a apresentação de uma resolução final.

A primeira característica do método casuísta é a ordenação dos casos por paradigma e analogia, segundo um princípio. Ao iniciar cada tópico, o casuista oferece uma definição dos termos-chave e depois propõe exemplos de casos que possibilitam questionar se uma dada ação descrita de um determinado modo configura ou não uma ofensa moral. $\mathrm{Na}$ abertura da série de casos, encontra-se exposto o desvio mais óbvio, um exemplo extremo que serve como "caso paradigmático" e ilustra a violação mais manifesta do princípio geral, tomado em seu sentido mais óbvio. Dando prosseguimento, apresentam-se os casos que se afastam do paradigma, introduzindo várias combinações de circunstâncias e motivos que tornam a afronta menos aparente. 
A segunda característica da casuística é o uso de máximas. Se, por um lado, a classificação dos casos toma por base um inquestionável princípio moral, como um mandamento do Decálogo, por outro, os argumentos evocam fórmulas retiradas de discussões tradicionais, expressas de maneira aforística e que se prestam como sustentáculo e garantia da argumentação. As máximas, então, consistem em pequenos ditos extraídos da sabedoria popular, literatura e epítetos dos sábios, comumente reconhecidas como verdades, ao menos em parte, que são usadas para iniciar um argumento.

A progressiva dificuldade dos casos constrói-se pela adição de circunstâncias complicadoras aos exemplos paradigmáticos. Os casuístas recorrem à tradicional lista de circunstâncias: quem, o que, onde, quando, por que, como e por quais meios. Chamam a atenção para essas circunstâncias, insistindo que são elas que conformam o caso e, inevitavelmente, modificam o juízo ético acerca da questão envolvida.

As opiniões sobre os casos não paradigmáticos raramente são emitidas como necessárias, conclusivas ou apodícticas, ao invés disso, com base na argumentação e autoridade, carregam-se de maior ou menor convicção. Desta forma, de acordo com o gradiente de probabilidade de suas conclusões, os casos são qualificados como: certo; mais ou menos provável; fragilmente provável e dificilmente provável. Esta escala de qualificação representa o juízo do casuísta acerca da força dos argumentos e do peso das autoridades que advogam as opiniões em pauta. $\dot{E}$ de posse desta qualificação que as pessoas podem avaliar a extensão do risco de infringir um princípio ético em questão e tomar suas decisões.

Os casuístas utilizam argumentos breves que apresentam vários tipos distintos de razões para sustentar suas conclusões, como textos das escrituras, citações da lei canônica e apelos às virtudes da caridade ou justiça, sem qualquer esforço para integrá-los em um único arrazoado consistente. A conclusão de que uma opinião merece ser classificada como mais ou menos provável não se baseia no rigor da lógica do argumento, mas na acumulação de múltiplas e variadas justificativas, ou 
seja, o peso de uma opinião casuística decorre mais do acúmulo de razões do que da validade lógica dos argumentos ou da consistência de qualquer prova.

A meta dos casuístas é chegar o mais próximo possivel da decisão e da ação, portanto, sempre encerram sua análise acerca de um caso com uma solução e um conselho relativo à licitude ou permissibilidade para agir de um ou outro modo. Nos casos dificeis de serem solucionados, as resoluções são enunciadas como mais ou menos prováveis, com a introdução de alertas do tipo: 'nessas circunstâncias, dadas essas condições, você pode com razoável segurança agir de tal e tal modo' ou 'fazendo dessa forma, você não agirá precipitada ou imprudentemente e somente pode estar em boa consciência' (JONSEN e TOULMIN 1988, p.256).

A partir dessas características da casuística que incluem o arranjo dos casos por paradigma e analogia; os apelos a máximas; as análises de circunstâncias; a qualificação de opiniões; o acúmulo de múltiplos argumentos e a proclamação de resoluções práticas de problemas éticos particulares à luz destas considerações, Jonsen e Toulmin propõem como conceituação para casuística:

"a análise de problemas morais, usando procedimentos de equacionamento baseados em paradigmas e analogias, guiando-se pelas opiniões formuladas por expertos sobre a existência e o rigor das obrigações morais particulares, modeladas em termos de regras e máximas que são gerais mas não universais ou invariáveis, uma vez que asseguram o bem com certeza somente nas condições típicas do agente e das circunstâncias da ação." (JONSEN e TOULMIN 1988, p. 257).

Desta conceituação, como alertam os próprios autores, depreende-se que nas questões de natureza ética o que conta realmente é a habilidade para reconhecer, de maneira completa e com sutileza de detalhes, as características relevantes dos casos em particular, isto é, as circunstâncias da ação e as condições do agente, tendo 
importância reduzida o domínio prévio dos princípios, das definições e dos axiomas. Assim, o equacionamento ético na prática não é uma questão de engendrar deduções formais de axiomas invariáveis, mas de exercitar o juízo, de ponderar considerações umas contra as outras. Conseqüentemente, a casuística vai proporcionar um alcance limitado para generalizações universais e inflexíveis, pois se reconhece que as regras ou máximas são gerais em sua forma, mas restritas em seu alcance prático pelo fato de poderem ser aplicadas sem questionamentos apenas nos casos que se aproximam bastante do paradigmático, em termos dos quais são definidas.

\subsubsection{A CASUÍSTICA NA ÉTICA CLÍNICA}

Entendendo que o modo dos casuístas analisarem $\mathrm{e}$ resolverem as perplexidades éticas guarda afinidade metodológica com a forma dos clínicos lidarem com os problemas médicos de diagnóstico na prática clínica e acreditando que os profissionais de saúde precisam de um método próprio que lhes proporcione um caminho claro para ordenar os fatos e os valores de cada caso em tela com vistas a facilitar a discussão e a resolução dos problemas éticos que se apresentam, Albert R. Jonsen, que é filósofo, junta-se a um médico, Mark Siegler e a um advogado, William J. Winslade para desenvolverem uma metodologia a ser utilizada nestas situações.

Este método, que toma por base vários dos elementos da casuística como o arranjo dos casos por paradigma e analogia, a análise das circunstâncias, o acúmulo de múltiplos argumentos e a proclamação de resoluções práticas, está apresentado na obra Clinical ethics: a practical approach to ethical decisions in clinical medicine, cuja quarta edição de 1998, traduzida para o português em 1999 é que serve de referência principal para esta parte do presente estudo (JONSEN e col. 1999).

Segundo os autores, a ética clínica é uma disciplina de cunho prático que propicia uma abordagem estruturada com vistas a ajudar os profissionais de saúde a 
identificar, analisar e resolver os problemas éticos que emanam da prática clínica. Aborda os aspectos éticos presentes em qualquer ato clínico e os problemas que podem surgir, especialmente quando os profissionais e os usuários discordam sobre valores ou enfrentam opções que desafiam suas convicções. Depende da firme convicção de que, mesmo diante de uma grande perplexidade e fortes emoções, os profissionais de saúde podem trabalhar construtivamente para identificar, analisar e resolver muitos dos problemas éticos que surgem na prática clínica.

O método por eles proposto não começa com os aspectos reais de cada caso e nem com os princípios e regras, como é comum nos tratados de ética. Na medida em que surgem na discussão dos tópicos, os princípios e regras são referidos, sendo apreciados no contexto específico das circunstâncias reais dos casos. Deste modo, entendem os autores, evita-se a discussão abstrata de princípios e preveni-se a tendência de encarar um único princípio como diretriz em determinada situação.

Segundo o método proposto, cada caso clínico, quando observado como problema ético, deve ser analisado em função de quatro tópicos: indicações médicas; preferências do doente; qualidade de vida e aspectos conjunturais ${ }^{20}$. Apesar dos fatos de cada caso diferirem, os quatro tópicos são sempre relevantes e organizam as distintas informações, chamando a atenção para os princípios éticos mais apropriados a cada situação. Oferecem um caminho sistematizado para identificar, analisar e resolver problemas éticos que surgem na prática clínica, sendo os equivalentes éticos dos tópicos clínicos utilizados pelos médicos na apresentação dos casos, na formulação de um diagnóstico e na prescrição de um plano terapêutico, ou seja, correspondem aos itens: queixa principal do doente, história atual, pregressa, familiar e social da doença, exame clínico e dados laboratoriais.

Os títulos dos tópicos descrevem as principais características que definem a ética da prática clínica, sendo que estas adquirem especificidades e apresentam-se de forma concreta a partir das circunstâncias reais dos casos. Assim, a cada caso, os quatro tópicos devem ser revistos, com a finalidade de averiguar como o conjunto de

\footnotetext{
${ }^{20}$ São mantidas as trađuções dos títulos dos tópicos constantes da edição em português.
} 
princípios e circunstâncias definem o problema em questão e que resolução sugerem. As situações com as quais os profissionais de saúde deparam-se na prática clínica podem levantar problemas que não são paradigmáticos, constituindo-se uma combinação única e complexa de circunstâncias e valores. Os quatro tópicos configuram referências que orientam o caminho através da ambigüidade $\mathrm{e}$ dificuldade dos casos reais.

A análise ética deve ocorrer com base numa revisão ordenada dos tópicos, sendo recomendado seguir em todos os casos a mesma seqüência, que se inicia pela apreciação das indicações médicas, seguindo com as preferências do doente, a qualidade de vida e terminando com a abordagem dos aspectos conjunturais. Este procedimento presta-se tanto à esquematização dos fatos éticos relevantes no caso, quanto à elucidação da necessidade de se obter mais informação antes de dar início ao debate.

A revisão dos quatro tópicos, além de constituir um estratagema de organização para ensino e discussão, orienta a discussão de um problema ético no sentido de sua resolução. Em outras palavras, defendem que as discussões devem ultrapassar o mero discurso ou debate e conduzir a uma solução prática e sensata. Por isto, após a apresentação de um caso, tem início a tarefa de procurar a resolução do problema em questão.

Os autores assinalam que, embora a análise dos problemas éticos inicie-se pelas circunstâncias reais dos casos, a discussão de cada tópico levanta e pressupõe certas noções de ética, que propõem determinadas normas de comportamento e atitudes aceitas ou indicadas para determinada situação. Assim, a competência em ética clínica não depende somente de ser capaz de usar um método de análise, mas da familiaridade com a literatura sobre o tema. Por esta razão, em sua obra, Jonsen e col. (1999), além de apresentarem o método de cunho casuísta para a análise dos problemas, incluem indicações de textos sobre ética e ética clínica. 
No tópico denominado indicações médicas abarca-se o conteúdo usual de uma discussão clínica, isto é, o diagnóstico e o tratamento da condição patológica do paciente. A expressão "indicações" refere-se à relação entre a fisiopatologia apresentada pela pessoa e o diagnóstico e as intervenções terapêuticas indicadas, ou seja, as apropriadas à avaliação e ao tratamento da ocorrência presente. Uma visão clara dos possiveis beneficios da intervenção constitui o primeiro passo na avaliação dos aspectos éticos de um caso, ou melhor, qualquer discussão de problemas éticos na prática clínica deve começar pela exposição dos fatos clínicos da situação. Assim, a análise não deve se iniciar com a pergunta "tem o doente direito de recusar o tratamento", mas antes com respostas à questão "quais são as indicações médicas para o tratamento" (JONSEN e col. 1999, p.15).

Portanto, a cuidadosa apresentação e a clara compreensão das queixas, do estado do paciente, da natureza do agravo, do diagnóstico, do prognóstico e dos recursos terapêuticos a fim de determinar que benefícios, ou em outras palavras, que objetivos da intervenção médica são plausíveis de serem alcançados em cada caso em particular são cruciais para o entendimento de qualquer pendência ética que possa surgir.

Para os autores, toda atuação médica deve alcançar todos ou, ao menos, um dos seguintes objetivos (JONSEN e col. 1999, p. 16):

a) promoção da saúde e prevenção da doença;

b) alívio dos sintomas, dor e sofrimento;

c) cura da doença;

d) prevenção da morte prematura;

e) melhoria do estado funcional ou manutenção da função residual;

f) educação e aconselhamento do doente face a sua doença e prognóstico;

g) não lesão do doente no decurso do tratamento

Na opinião deles, não é raro que o problema ético num caso em particular advenha da falta de clareza acerca dos objetivos da intervenção ou da aparente incompatibilidade entre eles. É por esta razão que as análises éticas devem se abrir 
com uma avaliação realista dos objetivos das indicações de intervenção médica, que têm de ser explicitamente apresentados pelos profissionais de saúde de modo que a própria equipe, os pacientes e a família possam compreender as alternativas disponiveis para a situação. Apenas depois de clarificadas as opções de intervenção, é que os outros tópicos (preferências do paciente, qualidade de vida e aspectos conjunturais) podem ser considerados.

O juizo clínico, objeto do primeiro tópico, conduz a uma recomendação que é apresentada ao doente que vai decidir, segundo sua preferência. A escolha da pessoa informada para aceitar ou recusar a conduta proposta tem importância ética, legal, clínica e psicológica. As preferências do paciente constituem o núcleo ético e legal da relação clínica, portanto, o conhecimento das predileções do paciente é essencial para a boa atuação dos profissionais de saúde, já que a cooperação e satisfação dos primeiros refletem em que medida a intervenção programada vem ao encontro de suas necessidades, opções e valores. A deliberação do paciente é baseada nas indicações e em suas preferências.

Depois de terem sido consideradas as indicações médicas e as preferências do paciente, segue-se uma apreciação acerca da qualidade de vida do doente, antes da doença atual e a esperada com ou sem tratamento. Qualquer agravo ou lesão ameaça as pessoas com uma diminuição, real ou potencial, de sua qualidade de vida, por isso o objetivo fundamental da intervenção médica deve ser restaurar, manter ou melhorar a qualidade de vida dos que buscam esse tipo de atenção. A avaliação da qualidade de vida deve ser levada em conta em todas as discussões acerca do cuidado à saúde, devendo os profissionais de saúde e as pessoas de quem cuidam estimar que nível de qualidade de vida é desejável, como este pode ser atingido e quais os riscos e vantagens. Ao contrário do balanço risco-beneficio que se preocupa com um âmbito relativamente mais imediato, as considerações sobre a qualidade de vida focam-se nas conseqüências a longo prazo da aceitação ou recusa das indicações. É o mais delicado ou perigoso dos tópicos porque pode abrir espaço para distorções e/ou preconceitos. Neste sentido, apontam-se como questões importantes: quem faz a 
avaliação, com que critérios é feita e que tipo de decisão clínica pode ser justificada com base nos juízos sobre qualidade de vida.

Nos aspectos conjunturais discutem-se as circunstâncias sociais, legais e institucionais nas quais um caso em particular se desenrola, ou seja, o contexto do caso, sendo por isto que este tópico também é denominado 'aspectos contextuais'. Os casos ocorrem em meio a uma trama complexa que urde pessoas, instituições e organizações econômicas e sociais. Os cuidados prestados são influenciados positiva ou negativamente pelas possibilidades e limites desse contexto que, ao mesmo tempo, também é afetado pelas decisões tomadas pelo paciente ou em seu nome, já que estas exercem impacto psicológico, emocional, econômico, legal, científico, educacional ou religioso sobre terceiros.

Estas características contextuais podem ter importância crucial na compreensão e resolução do caso, especialmente nos momentos atuais, quando a relação clínica é mediada por estruturas institucionais e econômicas de complexidade jamais atingida na área da saúde. Em alguns casos podem adquirir tal relevância que se tornam decisivos, entretanto, dada à multiplicidade e complexidade destes aspectos, é dificil estabelecer uma regra geral sobre sua prioridade. Na opinião dos autores, os aspectos conjunturais não devem ser decisivos em detrimento das indicações médicas; das preferências do paciente ou da qualidade de vida, nesta respectiva ordem. Desta maneira, para que tenham peso decisivo nas situações clínicas, faz-se necessário preencher, na integralidade, as seguintes condições: o alcance de objetivos significativos da intervenção médica é duvidoso; as preferências do paciente são desconhecidas e não é possível conhecê-las; a qualidade de vida do paciente é mínima ou abaixo da mínima; o aspecto contextual em questão é específico, nitidamente lesivo para terceiros e a decisão faz diferença em termos do alívio dessa lesão.

As perguntas a serem respondidas durante as discussões de cada tópico estão resumidas no quadro a seguir (JONSEN e col. 1999, p. 12): 


\begin{tabular}{|c|c|}
\hline INDICAÇÕES MÉDICAS & PREFERENCIAS DO DOENTE \\
\hline $\begin{array}{l}\text { 1. Qual o problema do doente? } \\
\text { História? Diagnóstico? Prognóstico? } \\
\text { 2. O problema é agudo? Crônico? } \\
\text { Crítico? Emergência? Reversivel? } \\
\text { 3. Quais os objetivos do tratamento? } \\
\text { 4. Quais são as hipóteses de sucesso? } \\
\text { 5. Quais são os planos em caso de falha } \\
\text { terapêtica? } \\
\text { 6. Em resumo, como este paciente vai } \\
\text { se beneficiar dos cuidados médicos e } \\
\text { de enfermagem e como os danos } \\
\text { podem ser evitados? }\end{array}$ & $\begin{array}{l}\text { 1. O que expressou o paciente acerca } \\
\text { das preferências pelo tratamento? } \\
\text { 2. O paciente foi informado sobre } \\
\text { beneficios e riscos, compreendeu e } \\
\text { deu seu consentimento? } \\
\text { 3. O paciente está mentalmente capaz e } \\
\text { tem competência legal? O que é } \\
\text { demonstrativo da incapacidade? } \\
\text { 4. O paciente expressou } \\
\text { antecipadamente suas preferências? } \\
\text { Por exemplo: diretrizes prévias? } \\
\text { 5. Se incapacitado, quem deve ser o } \\
\text { representante? O representante segue } \\
\text { as regras apropriadas? } \\
\text { 6. O paciente está relutante ao } \\
\text { tratamento ou é incapaz de cooperar? } \\
\text { Se sim, por quê? } \\
\text { 7. Em suma, foram os direitos de } \\
\text { escolha do paciente respeitados em } \\
\text { toda a sua extensão ética e legal? }\end{array}$ \\
\hline QUALIDADE DE VIDA & ASPECTOS CONJUNTURAIS \\
\hline $\begin{array}{l}\text { 1. Quais são as perspectivas, com e sem } \\
\text { tratamento, para um retorno do } \\
\text { paciente a sua vida normal? } \\
\text { 2. Há predisposições que possam } \\
\text { prejudicar a avaliação da qualidade } \\
\text { de vida do paciente? } \\
\text { 3. Que déficit físico, mental e social } \\
\text { pode o paciente sofrer se o } \\
\text { tratamento for bem sucedido? } \\
\text { 4. A situação presente ou futura do } \\
\text { paciente é tal que a continuação da } \\
\text { vida pode ser considerada } \\
\text { indesejável por ele? } \\
\text { 5. Existe alguma fundamentação lógica } \\
\text { para renúncia do tratamento? } \\
\text { 6. Quais os planos para os cuidados } \\
\text { paliativos e o conforto? }\end{array}$ & $\begin{array}{l}\text { 1. Existem assuntos familiares que } \\
\text { possam influir nas decisões } \\
\text { terapêuticas? } \\
\text { 2. Existem problemas dos profissionais } \\
\text { (médicos ou enfermeiras) que } \\
\text { possam influenciar as decisões } \\
\text { terapêuticas? } \\
\text { 3. Existem fatores econômicos ou } \\
\text { sociais? } \\
\text { 4. Existem fatores religiosos ou } \\
\text { culturais? } \\
\text { 5. Há alguma justificação para violar o } \\
\text { segredo médico? } \\
\text { 6. Existem problemas de alocação de } \\
\text { recursos? } \\
\text { 7. Quais as implicações legais das } \\
\text { decisões terapêuticas? } \\
\text { 8. Está envolvida a investigação ou o } \\
\text { ensino? } \\
\text { 9. Existe conflito de interesse } \\
\text { institucional ou com os profissionais } \\
\text { de saúde? }\end{array}$ \\
\hline
\end{tabular}

De acordo com o método proposto, depois de delinear os detalhes segundo os quatro tópicos, há ainda uma outra série de questões que devem ser respondidas, como: qual é a questão ética no presente caso; onde está o conflito; a que se refere o 
caso; é parecido com outros já encontrados; o que se conhece sobre outros casos similares a esse; há precedentes claros; é um caso paradigmático; em que medida o atual se aproxima do caso paradigmático ou difere; sua similitude ou diferença ao paradigmático é eticamente significante e em que medida a resolução de qualquer outro caso em particular dependerá dos fatos do presente.

Somente após vencer todos estes passos estipulados para análise do caso é que se está apto a identificar o problema ético em questão e pode-se traçar cursos alternativos de ação, no sentido de sua resolução.

\subsection{O ENFOQUE DA ÉTICA PROFISSIONAL: A ÊNFASE NOS CÓDIGOS DEONTÓLOGICOS}

A ética clássica defende a existência de um Código Único de preceitos e obrigações, que por ser tomado como algo revelado deveria ser cumprido pelas pessoas, sem discussão. Este Código Único tradicionalmente se expressa sob a forma de leis, preceitos e mandamentos, o que, por vezes, provoca a coincidência dos procedimentos éticos e jurídicos. $\mathrm{Na}$ religião, a ética religiosa converte-se no direito canônico e no âmbito civil isto se aplica às profissões, chegando-se mesmo a confundir o desempenho profissional com as normas éticas ou jurídicas. Assim, os campos profissionais têm uma dimensão ético-jurídica que, usualmente, é conhecida como a deontológica (GRACIA 1991; ARROYO-GORDO 1997).

A palavra deontologia deriva do grego déon, déontos, que significa dever, obrigação, regras, aquilo que se deve fazer. Correntemente, fala-se de deontologia como a ciência dos deveres, no entanto, como registra a entrada do verbete no Vocabulário Técnico e Crítico da Filosofia, o mais adequado é compreendê-la como "teoria dos deveres", já que "este termo não se aplica à ciência do dever em geral, no sentido kantiano". Ao contrário, traz consigo a idéia do estudo empírico dos 
diferentes deveres relacionados a uma dada situação social (LALANDE 1999, p. 239).

As profissões constituem exemplos característicos de situações sociais que são alvo da deontologia. Historicamente, aparece relacionada à experiência das profissões liberais tradicionais, como a medicina e o direito, estendendo-se, mais tarde, a outras, como enfermagem e arquitetura. Surgem, então, para marcar as diversas práticas profissionais, códigos de comportamento para advogados, fiscais, juízes, engenheiros, médicos, jornalistas, enfermeiros, investigadores, educadores etc.

Neste sentido, a deontologia indica o conjunto de deveres inerentes ao exercício de uma profissão, isto é, conforma o conjunto codificado das obrigações impostas aos profissionais no exercício de sua profissão. Define como alguém deve se comportar na qualidade de membro de um corpo sócio-profissional determinado, apontando os comportamentos oportunos ou os que devem ser evitados a fim de que a imagem social da profissão seja favorecida ou, ao menos, não se veja ofuscada ou prejudicada. Fica claro, então, que a deontologia não pretende guiar a consciência ética individual dos que conformam uma categoria profissional, residindo sua preocupação na justeza da ação, considerando a profissão, a sociedade e a relação entre ambas. As regras de comportamento são, usualmente, reunidas em códigos conhecidos como "códigos de deontologia" ou "códigos de ética profissional". Adotados oficialmente pelos distintos corpos profissionais, em alguns países, impõem sanções aos membros das corporações que porventura falharem em sua observância. Por isto, num senso jurídico, a deontologia pode ser considerada uma extensão do direito profissional (FURLAN 1985; SPINSANTI 1990; DURANT 1995; ARROYO-GORDO 1997; FORTES 1998).

Os colegiados, os conselhos e as associações profissionais promulgam os códigos com a intenção de se autoregularem e de poderem resolver seus conflitos internamente, evitando, assim, acudir ao aparato judiciário comum à sociedade. $\mathrm{O}$ sentido dessas regras está em assegurar a convivência ou a utilidade de um corpo 
sócio-profissional, para que este possa conseguir, da melhor forma, o fim que deseja alcançar. Na medida em que a categoria profissional pretende fechar-se em si e impedir qualquer juízo externo, este modo de proceder é passível de uma leitura gremial e corporativista. Entretanto, não convém esquecer que é positivo o fato dos profissionais tomarem consciência das exigências de sua profissão e serem os primeiros interessados em dignificá-la. (ORTIZ-IBARZ 1995; CORTINA 1997b).

Ao reunirem as orientações gerais que servem de diretrizes e limites para os profissionais no cumprimento de suas funções, os códigos indicam pontos de reflexão, sendo esta, talvez, sua maior utilidade. Além disto, podem impedir o que Conill (1993), citado por ORTIZ-IBARZ (1995, p. 116), chama de o "paradoxo do isolamento" ("paradoja del aislamiento"), segundo o qual, cada um deseja atuar bem eticamente desde que os demais também o façam, mas se for o único a atuar dessa forma, não o fará (ORTIZ-IBARZ 1995).

Embora válida, a perspectiva dos deveres deontológicos mostra-se limitada, pois os códigos podem conformar um esquema redutor incapaz, muitas vezes, de fazer frente aos problemas e/ou dilemas éticos que surgem das experiências vivenciadas no cotidiano profissional. Daí a necessidade de plasmá-los com a perspectiva ética de abrangência mais ampla que vai além dos deveres mínimos expressos nos códigos e busca a excelência profissional (SPINSANTI 1990; GRACIA 1991; ARROYO-GORDO 1997; CORTINA 1997a.).

Convém lembrar que a adoção de um código não supre a responsabilidade da decisão pessoal, pois a noção de ética não se resume a uma obrigação por efeito de coação externa, mas supõe o livre consentimento e a adesão espontânea do indivíduo. O sujeito ético não é o que se submete a regras simplesmente por obrigação ou temor à determinada punição, mas sim porque nelas acredita e está convencido de seu valor e de sua legitimidade. Daí a essencialidade do conteúdo dos códigos ser aceito pelos integrantes de uma categoria profissional. $\mathrm{Na}$ verdade, os autores destes códigos deveriam ser os próprios profissionais que refletem e analisam, de maneira crítica, a prática cotidiana do exercício de sua profissão. Por outro lado, ainda que o temor às 
punições não seja a forma ideal de se conseguir a observância dos códigos, a previsão destas pode constituir fator de auxílio para tal. Como lembra ORTIZIBARZ (1995), é muito importante que um código não fique reduzido a uma declaração de boas intenções. Assim, se quiser ser eficaz, um código deve especificar as consequêencias decorrentes de sua inobservância (CORTESE e FEDRIGOTTI 1985; ORTIZ-IBARZ 1995).

Fundamentando-se no caráter inquestionável e inegociável da dignidade e da integridade pessoais; da veracidade; da necessidade de estabelecer relações justas e de atuar segundo a prudência, o conteúdo dos códigos deontológicos procura dar respostas a algumas questões, como:

- quem é o principal cliente do grupo profissional;

- quais os valores centrais da profissão;

- quais os parâmetros de um relacionamento ideal entre os profissionais e os clientes ou a comunidade;

- quais os sacrifícios exigidos aos membros da profissão e em que condições as suas obrigações devem constituir prioridade, até mesmo em relação a outras questões éticas que os afetem;

- quais as normas de competência da profissão;

- no que constitui e baseia-se a relação ideal entre os membros de uma profissão;

- quais os deveres de cada profissional, a fim de preservar a integridade de seu compromisso com os valores e educar os demais quanto a este aspecto (OZAR 1995; ORTIZ-IBARZ 1995).

No Brasil, as normas deontológicas gozam de poder coercitivo com a garantia, pelo poder estatal, de sanções às violações. Os profissionais de saúde, por exemplo, a fim de legalizar o exercício de sua profissão, segundo a legislação brasileira, estão obrigados a se inscreverem no conselho profissional de sua categoria. Este órgão de classe que, em conformidade com a legislação e a ética, 
fiscaliza o exercício profissional, pode punir ou mesmo impedir o exercício da atividade de qualquer um dos profissionais sob sua jurisdição. O Conselho Federal configura o órgão máximo, com jurisdição em todo o país. Os "Conselhos Regionais" têm sua jurisdição restrita a uma região, freqüentemente uma Unidade Federativa. Cada profissão conta com o seu respectivo Conselho nas diferentes jurisdições. O bacharel em qualquer área somente torna-se um profissional mediante seu registro no respectivo Conselho. Após a inscrição nestes órgãos, é que os bacharéis em toda profissão regulamentada podem exercê-las. A lei que regulamenta uma profissão fixa seu campo de atividade e as condições para o seu exercício, exigindo, geralmente, a conclusão de cursos, alguns em nível universitário (PINHO e NASCIMENTO 1997; FORTES 1998).

No caso da enfermagem e da medicina, para auxiliar os Conselhos na fiscalização do exercício profissional e cumprimento do código deontológico, há as comissões de ética locais, que devem ser constituídas no âmbito das instituições de saúde por exigências de resoluções dos respectivos Conselhos. As Comissões de Ética Médica e de Ética em Enfermagem têm como principal função a apuração de fatos em situações que pareçam atentar contra os princípios que regem a deontologia de cada profissão, funcionando como uma extensão dos próprios Conselhos, que as regem e acompanham.

Os códigos deontológicos podem configurar um instrumental útil enquanto uma diretriz da prática profissional e também do processo de tomada de decisão frente a situações que configuram problemas éticos. A explanação acerca dos códigos feita nesta parte não tem por objetivos explorar os valores e o referencial ético filosófico dos códigos deontológicos de medicina e enfermagem, pretendo-se apenas registrar que estes podem conformar um aporte para o equacionamento ético dos profissionais de saúde que, por vezes, recorrem aos códigos e às comissões de ética institucionais como fontes de recursos para orientação e solução dos problemas éticos enfrentados. 


\section{RESULTADOS E DISCUSSÃO}

\subsection{RESULTADOS E DISCUSSÃO: MOMENTO I}

Para o momento I, são considerados 17 depoimentos dos enfermeiros e 16 dos médicos. De cada grupo exclui-se uma entrevista (enfermeiro 6 e médico 6) por narrarem situações vividas em USF fora dos limites delimitados para a coleta de dados, ou seja, contam casos de seu tempo de trabalho em PSF de fora do Município de São Paulo.

Do total de 33 depoimentos analisados, 20 (10 em cada grupo) contêm relatos de casos que envolvem problemas éticos encontrados na tomada de decisão perante os usuários e/ou suas famílias; 6 ( 2 enfermeiros e 4 médicos) listam problemas éticos em geral do PSF, sem narrar nenhuma experiência específica; 2 enfermeiros apontam situações de discordância e desentendimento entre os integrantes da equipe, sem o envolvimento direto de usuários; 3 enfermeiros assinalam rotinas administrativas como potenciais fatores geradores dos problemas; 1 médico apresenta um caso envolvendo divulgação científica e, por fim, merece destaque o depoimento de um dos médicos que afirma não ter presenciado até então problema ético algum e por isto não poderia narrar nenhum caso, apenas cita situações de desentendimento que já presenciou na USF entre os profissionais e destes com os usuários, mesmo sem considerá-las problemas.

Cabe pontuar que esta distribuição reflete as orientações dadas pela pesquisadora aos entrevistados no momento da coleta dos depoimentos, pois, como a intenção consiste em conhecer a abrangência dos problemas éticos vivenciados na atenção básica e também as circunstâncias das quais emergem, dá-se liberdade aos profissionais para que apresentem as situações que queiram, sem a indicação para que se restrinjam às que dizem respeito aos usuários. Ainda é oportuno assinalar que a introdução da palavra "caso" na pergunta que inicia a entrevista, uma vez que este 
é um termo comum do vocabulário clínico, representa uma tentativa de privilegiar problemas éticos relativos ao relacionamento com o usuário, entretanto, quando os enfermeiros e médicos perguntam se obrigatoriamente têm que contar casos que viveram com usuários foi lhes explicado que não, que poderiam narrar o problema ético que desejassem. A investida de privilegiar situações com o usuário não significa uma redução do espectro para as atividades de cunho clínico em detrimento das questões estruturais que determinam o surgimento de problemas éticos, mas como o PSF baseia-se na responsabilização e no vínculo da equipe com as pessoas de sua área, tenta-se iluminar especialmente os problemas que poderiam irromper deste contato mais próximo e vincular com as famílias.

Além dos casos relatados frente à questão panorâmica "conte-me um caso que seja um problema ético e com o qual você tenha se deparado em suas atividades no PSF", ao serem solicitados para listar os problemas éticos que encontravam na situação contada, muitos entrevistados acabaram elencando, além destes, outros pontos relativos à organização geral do PSF e da USF ou novos exemplos que ilustravam os problemas listados. Os problemas éticos apontados desta forma também são considerados na apresentação e discussão dos resultados.

Chama atenção nos discursos o fato de um enfermeiro afirmar que nunca viveu problemas éticos envolvendo usuário:

“(...) porque assim, um caso envolvendo o paciente, com o paciente propriamente dito eu não me lembro que eu tenha tido algum problema com ética, não" (E13)

"Então, na verdade, assim, com o paciente, não lembro de muitos, infelizmente é mais com pessoas aqui de dentro que a gente trabalha junto(....) eu acho mais dificil, às vezes, entre colegas do que entre o paciente" (E13) 
O presente achado guarda consonância com os resultados de outros estudos empíricos em ética realizados com enfermeiros e médicos de diferentes países, inclusive o Brasil, tanto em hospitais como em serviços de atenção básica, nos quais estes profissionais de saúde apontam seus colegas ou os membros da outra categoria profissional como fontes de problemas éticos, muitas vezes mais importantes que os usuários e/ou suas familias (PELLEGRINO e col. 1985; PRESCOTT e col. 1985; UDÉN e col. 1992; WAGNER e RONEN 1996; VAN DER AREND e REMMERSVAN DER HURK 1999; DUCATI E BOEMER 2001).

Dentre os depoentes médicos, encontram-se alguns que têm dificuldades para definir se as situações que vivenciam representam ou não problemas éticos:

"Dever ter, mas não tenho visto, todo lugar tem. Mas eu não vi (....) só vi essa briga mesmo (....) e não vi mais (....) eram médicos, os dois já saíram, e era por causa de fofoquinha. Não era nenhuma briga séria. (....) Não lembro mais nenhum. Não lembro nenhum médico sacaneando ou fazer receita para vender (....) Em hospital tá cheio. Quer de hospital ?" (MI)

"Já vi colegas brigar com paciente que escutei os gritos, mas não sei porque. Aqui não tem médico viciado, nem alcoólatra (....)" (M1)

“(....) também já bati de frente com paciente, mas não sei até que ponto essa coisa de ética, eu acho meio dificil até de a gente tá identificando até aonde é ética, até onde não é (....)" (M2)

“(....) eu realmente não me lembro ter tido nenhum problema assim mais sério em relação à ética, que feria a ética, hoje em dia, a ética está jogada pra escanteio. Talvez a minha idéia de ética seja uma outra coisa, seja uma coisa mais séria, mais grave. Talvez esse diaa-dia de rotina, como você me perguntou, no PSF, talvez esse dia-adia de rotina pra mim não seja uma quebra de ética, não seja, é uma 
coisa normal, que, para mim, é essas encrencas com pacientes, não sei até que ponto são ou não éticas." (M2)

Esta observação vem ao encontro das considerações feitas anteriormente acerca da sutileza dos problemas éticos vividos na atenção básica. Como os encontros com os usuários nesse âmbito da assistência caracterizam-se por episódios repetidos e de aparente simplicidade, diferenciando-se das crises bem definidas que requerem decisões instantâneas típicas do ambiente hospitalar, a forma como os problemas éticos emergem pode dificultar seu discernimento (SUGARMAN 2000).

Uma pesquisa qualitativa feita com médicos generalistas, em 1993, no Sul da Austrália, na qual se solicita, em entrevista semi-estruturada, que falem sobre um problema ético que tenham encontrado em sua prática, também aponta que, de maneira geral, as situações enfrentadas por estes profissionais, quando comparadas com as questões candentes e de maior destaque na literatura de bioética, parecem insignificantes ou comuns. Além disto, ao invés de focarem uma crise que ocorre raramente, trazem questões que surgem corriqueiramente (MAYER-BRAUNACK 2001).

Um estudo realizado em Israel, durante os anos de 1993 e 1994, com 506 enfermeiros que trabalham em hospitais e outros 239 que atuam na comunidade, em clínicas de enfermagem comunitária ou em serviços de saúde pública, indica que há diferenças entre os tipos de problemas enfrentados por estes dois grupos. Em um questionário auto-aplicado, cada enfermeira deveria indicar se, nos últimos doze meses, havia ou não vivenciado as 39 situações potencialmente geradoras de problemas éticos, abrangendo as esferas clínico-profissional, administrativa e interpessoal. Os achados mostram que em todas as áreas, exceto nas questões relativas à informação e confidencialidade, há diferenças segundo o local de trabalho, sendo que no ambiente hospitalar as enfermeiras são expostas a um leque mais variado de problemas, de distintas natureza e extensão. A análise de regressão feita para verificar a associação entre as características demográficas e profissionais dos sujeitos e os registros das situações geradoras de problemas revela que esta ocorre 
somente para a variável 'cenário do hospital versus a comunidade', deixando manifesto que as variações devem estar relacionadas às diferenças nas peculiaridades de cada cenário. Ainda comparando as enfermeiras das clínicas de enfermagem comunitária com as que atuam nos serviços de saúde pública voltados às ações de prevenção, as últimas encontram menos problemas do que as primeiras (WAGNER e RONEN 1996).

Entretanto, como salientam Connelly e DalleMura (1988), falhas em reconhecer a existência de problemas éticos no cotidiano das unidades básicas pode por em risco a atenção à saúde prestada nestes locais e resultar no rompimento da relação vincular estabelecida entre os profissionais e os usuários, isto porque embora os problemas identificados nesse contexto pareçam triviais frente ao que se vê no hospital e sejam sutis a ponto de passarem desapercebidos, implicam em consequiências desastrosas para os usuários individualmente, para as relações destes com os profissionais de saúde e para a comunidade.

Alguns discursos revelam que a repercussão do fato, por exemplo, com encaminhamento de denúncia para a comissão de ética profissional, pode estar relacionada a seu reconhecimento como problema ético ou não:

"Tem uma comissão de ética que acho que nunca funcionou aqui, porque nunca teve caso." (MI)

"Bom eu tive um problema muito sério, mas em hospital, em posto não tive assim nenhum problema que precisasse ir pra ética (....)" (M2)

“(....) não sei se entra como ética, mas o resguardo meu também, porque se vazasse, ela podia falar: 'não, eu só falei pra essa e pra aquele, um dos dois foi!'. Então a gente vê muita gente em processo, tem um médica que fala muito em processo, em processo! De repente poderia até dar...não sei!" (E18) 
$\mathrm{Na}$ pesquisa com os médicos generalistas do Sul da Austrália, citada em parágrafo precedente, quando perguntados porque a situação que discutem nas entrevistas configura um problema ético para eles, dentre as 24 explanações fornecidas encontra-se a um grupo que focaliza a publicidade que as cerca e outro que lida com a noção de ameaças à integridade ou à reputação dos profissionais (MAYER-BRAUNACK 2001).

Os discursos, após análise categorial temática, permitem identificar três grandes agrupamentos de problemas éticos segundo as diferentes dimensões dos relacionamentos no trabalho, como pode ser observado nos quadros 5 e 6 . 


\section{QUADRO 5 - PROBLEMAS ÉTICOS DESCRITOS PELOS ENFERMEIROS SEGUNDO CATEGORIAS}

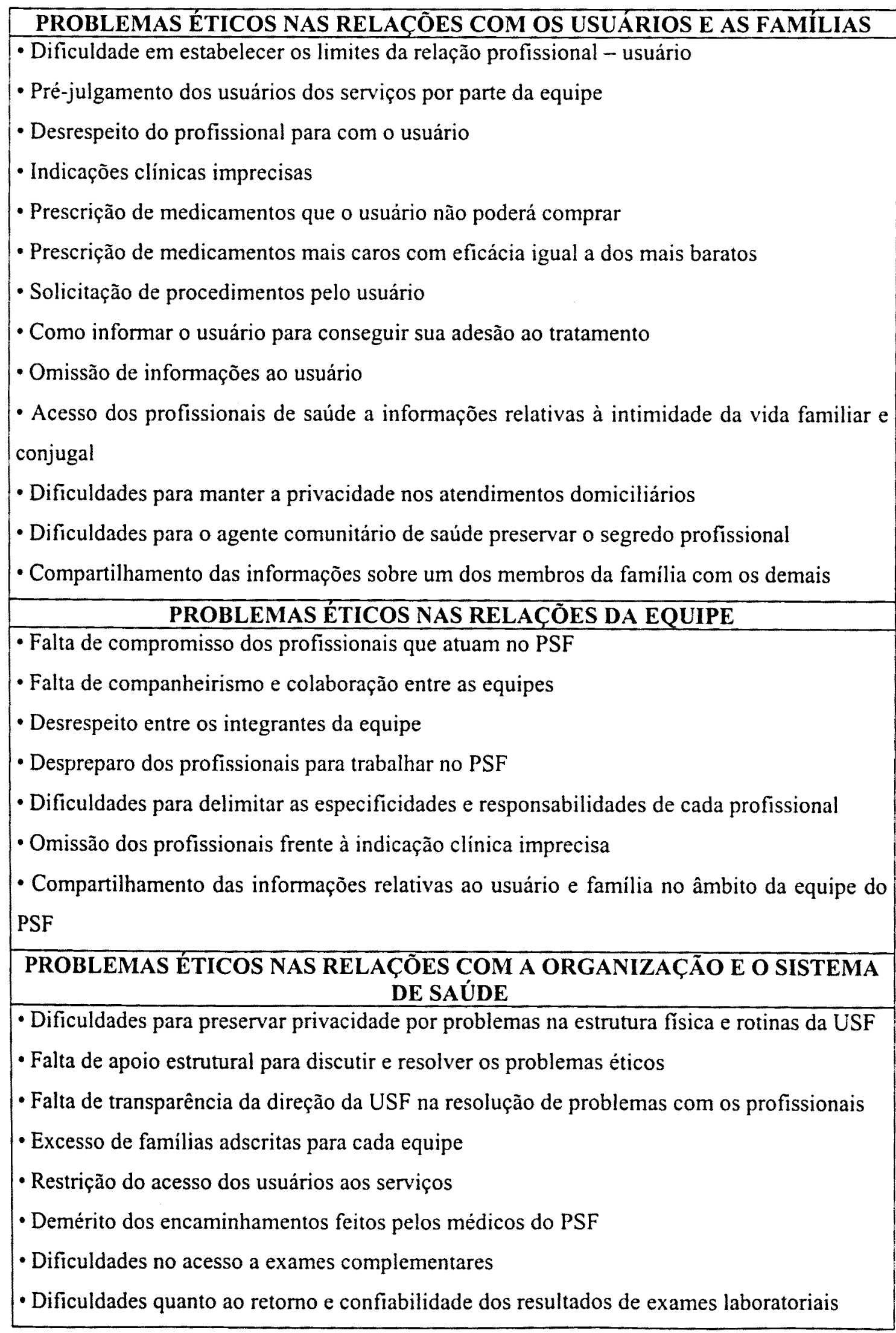




\section{QUADRO 6 - PROBLEMAS ÉTICOS DESCRITOS PELOS MÉDICOS SEGUNDO CATEGORIAS}

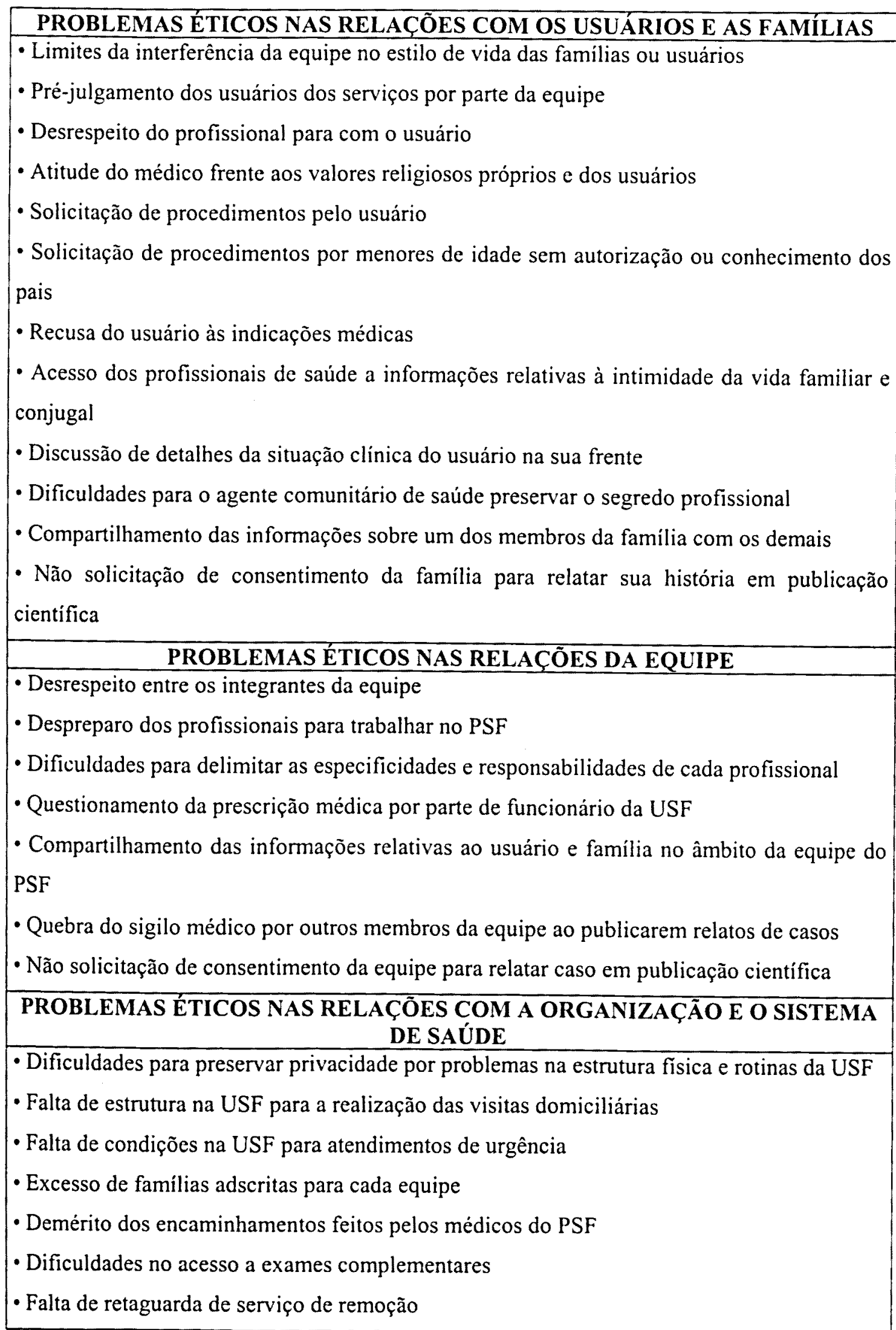


As listagens constantes nos dois quadros revelam, como aventado anteriormente, que os problemas éticos mais freqüentes na atenção básica representam preocupações pragmáticas do cotidiano da assistência à saúde nesse nível e não as situações dramáticas próprias do hospital e que são mais exploradas na literatura de bioética.

Robillard e col. (1989), em estudo realizado com diversos profissionais de saúde (médicos, enfermeiros, fisioterapeutas etc.) que trabalham em serviços de atenção básica no Kentuchy (EUA), também têm resultados que confirmam o fato das ocorrências éticas mais comuns na atenção básica configurarem as preocupações pragmáticas do dia a dia, especialmente as ligadas à prática clínica. Nessa pesquisa, os doze primeiros problemas apontados como os mais freqüentes não são dramáticos ou tampouco merecedores de destaque na midia, mas ocorrem repetidamente. Dentre eles também estão a falta de preparo e atualização dos profissionais de saúde; o trato desrespeitoso para com os usuários; a solicitação do usuário por procedimentos desnecessários; a informação inadequada aos usuários; a solicitação de informações por parte da familia impondo riscos a confidencialidade do usuário; a violação da confidencialidade do usuário e as dificuldades com serviços e procedimentos de referência.

Quanto a este último item, parece claro que devido às diferenças estruturais e políticas dos sistemas de saúde norte americano e brasileiro, as causas para o mesmo problema ético são percebidas de forma bem distintas pelos profissionais dos dois países, sendo que naquele se assinala como determinante a falta de condições do próprio usuário para pagar pelos cuidados, não se levantando questões da justiça na alocação de recursos em saúde ou da organização do sistema. Nesse sentido, é oportuno assinalar que em estudo feito 5 anos mais tarde, com enfermeiras da região oeste dos EUA, já se vê como um problema ético para os que atuam na atenção básica o direito e o acesso aos serviços de saúde, principalmente pelas situações geradas em conseqüência dos cortes de gastos e das restrições de procedimentos impostos pelos seguros-saúde, através da estratégia do managed care (VIENS 1994). 
O estudo de Israel, mencionado anteriormente, também aponta para uma coincidência de alguns problemas com os encontrados na presente pesquisa. Naquele estudo, entre os 10 problemas éticos mais freqüentes assinalados pelos enfermeiros que atuam em serviços comunitários figuram o conflito entre as necessidades dos usuários e da família (69\%); cuidado a usuários ofensivos $(85,1 \%)$; denúncia de atos incompetentes de médicos ou enfermeiros (57,3\%); comportamento insultuoso ou rude dos profissionais para com os usuários $(58,9 \%)$; omissão de informação ao usuário por pressões da família (45,2\%); administração de tratamento errado ou com validade questionável ( $52 \%$ e $49,8 \%$ respectivamente) e o constrangimento aos usuários que recusam tratamento $(48,2 \%)$. De acordo com os autores, as enfermeiras que trabalham na atenção básica, em comparação com as que estão na área hospitalar, mencionam mais freqüentemente as situações envolvendo questões de confidencialidade, estigmas, cobertura dos serviços de saúde e greves como potenciais geradoras de problemas (WAGNER e RONEN 1996).

Uma pesquisa empírica, exploratória, quali-quantitativa realizada, na década de 90 , com enfermeiros holandeses para identificar as questões que vivenciam como problemas éticos nos diferentes tipos de instituições de saúde também permite perceber a ocorrência de pontos semelhantes com os aqui encontrados. Naquele estudo, figuram como problemas mais freqüentes na atenção básica: demora na transferência do paciente para outros serviços (93,3\%); desacordo com ações prescritas $(45,9 \%)$; agressão verbal para com o usuário $(48,9 \%)$; conhecimento insuficiente dos enfermeiros (50\%); manter-se em silêncio sobre erros cometidos $(37,8 \%)$; persuadir o usuário a cooperar $(48,9 \%)$ e desacordo com as escolhas dos usuários (40,7\%) (VAN DER AREND e REMMERS-VAN DER HURK 1999).

Merece comentário o fato de que tanto no estudo citado no parágrafo anterior (VAN DER AREND e REMMERS-VAN DER HURK 1999) como no realizado em Israel (WAGNER e RONEN 1996) os problemas éticos apontados pelos enfermeiros que atuam em serviços de atenção básica também são assinalados como situações que ocorrem nos hospitais, às vezes até em proporção maior. Por exemplo, na 
pesquisa holandesa a agressão verbal é citada por $48,9 \%$ dos enfermeiros que estão na atenção básica e $67,6 \%$ dos que trabalham na área hospitalar e a diferença aumenta para o caso de manter-se em silêncio sobre erros cometidos, com $37,8 \%$ e $51,8 \%$ respectivamente. Parece, então, que estas questões pragmáticas do cotidiano da assistência que perfazem o perfil dos problemas éticos na atenção básica também estão presentes no hospital, mas as situações dramáticas e mais candentes acabam por encobri-las, sendo o que marca a diferença entre os dois cenários.

Neste sentido, vale trazer os resultados de alguns estudos da área hospitalar, como o desenvolvido com 125 gerentes de enfermagem de hospitais gerais de Minnesota (EUA), no qual se vê, ao lado da questão do 'tratamento versus não tratamento', bem discutida na literatura de bioética, situações relacionadas ao nível do staff, às relações entre os funcionários e aos enfermeiros e médicos incompetentes (SIETSEMA 1987). Noutra pesquisa realizada com enfermeiros de hospitais gerais da área metropolitana no noroeste Pacífico dos EUA, entre as cinco questões mais encontradas desfilam lado a lado 'prolongar a vida com medidas heróicas', 'staff inadequado' e ‘lidar com atividade de colegas irresponsáveis' (BERGER 1991).

Comparando-se as listagens dos enfermeiros e dos médicos é possível observar a percepção de problemas em comum. Na categoria 'problemas éticos nas relações com os usuários e famílias' são citadas tanto pelos enfermeiros como pelos médicos as questões relativas a pré-julgamento dos usuários dos serviços por parte da equipe; desrespeito do profissional para com o usuário; solicitação de procedimentos pelo usuário; acesso dos profissionais de saúde a informações relativas à intimidade da vida familiar e conjugal; dificuldades para o agente comunitário de saúde preservar o segredo profissional e compartilhamento das informações sobre um dos membros da família com os demais.

Neste sentido, é oportuno citar que no estudo quantitativo de Robillard e col. (1989), também realizado no ambiente da atenção básica, a solicitação de procedimentos pelo usuário e os pedidos de informação por parte da família impondo riscos à confidencialidade de um dos seus membros são percebidos como problemas 
éticos freqüentes, tanto pelos médicos como pelos outros profissionais de saúde entrevistados, sem diferença estatisticamente significante.

No presente estudo, nas relações de equipe, são mencionados como problemas éticos pelos dois grupos o desrespeito entre os integrantes da equipe; o despreparo dos profissionais para trabalhar no PSF; as dificuldades para delimitar as especificidades e responsabilidades de cada profissional e o compartilhamento das informações relativas ao usuário e família no âmbito da equipe do PSF. Já nos problemas éticos nas relações com a organização do sistema de saúde, em comum aparecem as dificuldades para preservar privacidade por problemas na estrutura fisica e rotinas da USF; o excesso de famílias adscritas para cada equipe; o demérito dos encaminhamentos feitos pelos médicos do PSF e as dificuldades no acesso a exames complementares.

Alguns pesquisadores têm estudado as diferenças entre enfermeiros e médicos no tocante à percepção de problemas éticos e seu equacionamento, com resultados variados. Amado-Grunstein (1992) ao entrevistar nove enfermeiros e nove médicos que trabalham em unidades para pacientes agudos e crônicos de dois hospitais de Toronto (Canadá) encontra achados que sugerem uma tendência dos primeiros apresentarem maior sensibilidade para as questões éticas. Também indicam que ambos entendem como importante buscar o melhor bem do usuário, entretanto sob perspectivas distintas, com os enfermeiros enfatizando mais a dignidade, o conforto $\mathrm{e}$ os desejos deste, enquanto que os médicos estão mais preocupados com os direitos dos usuários e a abordagem científica que implica focar mais a doença e sua cura.

Robillard e col. (1989) ao compararem médicos com outros profissionais de saúde que atuam na atenção básica encontram uma diferença estatisticamente significante entre os dois grupos no tocante ao registro da freqüência com a qual se deparam com problemas éticos. Isto ocorre para 28 dos 36 itens do questionário aplicado e, somente em dois deles, os médicos reportam uma proporção maior (tratamentos desnecessários aplicados pela preocupação de proteger-se legalmente e suspensão das medidas de suporte de vida), nos demais, o outro grupo afirma 
encontrar os problemas comumente ou ocasionalmente com mais freqüência, o que poderia indicar maior sensibilidade destes profissionais para as situações potencialmente problemáticas.

No presente estudo, embora os enfermeiros apontem, como pode ser observado nas listagens de problemas éticos constantes nos quadros 5 e 6 , duas situações a mais do que os médicos, devido à natureza qualitativa da pesquisa e a conformação da amostra para coleta de dados, não é possivel generalizar, afirmando que estes profissionais apresentam maior sensibilidade para a percepção dos problemas éticos que a categoria médica.

As similitudes entre os problemas éticos percebidos pelos dois grupos apontam para uma concordância em torno de $50 \%$ ou mais nas três categorias listadas. Isto vem ao encontro dos resultados do estudo realizado por Oberle e Hughes (2001) com enfermeiros e médicos de unidades médico-cirúrgicas de um hospital canadense que, na medida em que as categorias e os temas convergem e o problema nuclear é essencialmente o mesmo, tem como principal achado o das similaridades entre os profissionais, apesar de algumas diferenças éticas entre eles. Estas diferenças, de acordo com os autores, parecem ocorrer menos em virtude de uma diferença no compromisso ou no equacionamento ético do que em função da estrutura hierárquica da organização hospitalar e dos papéis designados para os médicos e as enfermeiras como provedores de cuidado à saúde, uma vez que aos médicos compete a responsabilidade de ter que tomar decisões e prescrever ordens, enquanto que aos enfermeiros é imposta a carga de viver com as decisões feitas por alguém. Por esta razão, fica evidente que estes profissionais fazem questionamentos distintos na mesma situação de assistência, pois enquanto os médicos preocupam-se com o processo de tomada de decisão em si, as enfermeiras, por não serem as protagonistas desta atividade, centram suas inquietudes no "como" e no "porquê" outros chegaram à determinada decisão.

No presente estudo, estas diferenças determinadas pelas distintas responsabilidades na atenção à saúde não ficam tão claras, provavelmente pelo fato 
disto ainda não estar bem definido no PSF e terem os médicos e os enfermeiros que atuam no Programa muito mais ações que se sobrepõem. Tanto é assim, que um dos problemas éticos mencionado por ambos grupos abarca as dificuldades para delimitar as especificidades e responsabilidades de cada profissional.

Apesar disto, vale destacar que somente os enfermeiros mencionam casos que narram situações de conflito e desacordo direto com os médicos. Os últimos, quando fazem alusão às dificuldades para estabelecer os limites de cada profissional, questionam o fato do PSF não reconhecer a importância do médico ou a legalidade dos atos feitos pela enfermagem, mas sem trazer qualquer ocorrência de confronto direto entre profissionais enfermeiros e médicos. Isto também é observado por Udén e col. (1992) ao pesquisarem enfermeiros e médicos dos departamentos de Medicina Interna e Oncologia do Hospital Universitário de Tromsö, na Noruega. Ao pedirem para que os entrevistados narrassem uma situação de cuidado que fosse eticamente problemática e que tivessem vivido na enfermaria, percebem que especialmente nas histórias dos enfermeiros e menos nas dos médicos, há menções de desacordo entre as duas profissões. Os médicos são freqüentemente apontados como fontes de conflitos éticos pelos enfermeiros; por outro lado, estes raramente são mencionados nas narrativas dos primeiros. Este estudo não é o único a sugerir esta questão, também as pesquisas de Gramelspacher e col. (1986) e de Oberle e Hughes (2001) têm achados semelhantes.

Outra questão que merece destaque é o fato dos enfermeiros, como sugere Viens (1994), estarem mais voltados à defesa do usuário e sua segurança. Isto talvez explique porque apenas estes profissionais no presente estudo apontam como problemas éticos situações de indicações clínicas imprecisas, omissão de informações ao usuário e omissão dos profissionais frente à indicação clínica imprecisa. Todas estas questões parecem envolver aspectos relativos à segureza da atenção prestada e à obrigação do enfermeiro de proteger o usuário de eventuais falhas, erros e danos. 
Esta preocupação em defender e proteger o usuário e seus direitos talvez decorra da proximidade com a pessoa a quem se presta assistência, que constitui outra característica própria dos enfermeiros, segundo os estudos de Udén e col (1992) e Amado-Grunstein (1992). No primeiro estudo, os médicos em suas narrativas expressam que uma relação próxima pode ser perigosa, pois pode levar o profissional a ser parcial quando decide sobre a alocação de recursos na unidade, enquanto isto as enfermeiras defendem que somente assim é possivel perceber os desejos dos usuários e prestar uma melhor assistência.

Isto pode explicar porque na presente pesquisa somente o grupo dos enfermeiros aponta como problema ético a dificuldade em estabelecer os limites da relação profissional - usuário. Esta discordância entre os dois profissionais acerca desta questão fica patente no discurso:

"Pra mim isso é um dilema importante. A relação mesmo, um ponto assim, o limite da relação profissional - familia, profissional paciente, é pra mim um dilema ético, porque assim eu acho que é mais pra cá, entendeu? E, assim, a médica acha que é mais pra lá (....) a gente faz a nossa parte e a gente não tem que se meter em outros assuntos (....) porque eu acho que a gente é responsável sim, a gente tem que fazer alguma coisa sim." (E5)

Outro ponto que chama a atenção está nas diferenças relativas ao respeito da autonomia do usuário. O estudo de Udén e col. (1992), com enfermeiros e médicos noruegueses, indica que os primeiros tendem a respeitar a autonomia dos usuários, enquanto que os últimos inclinam-se ao paternalismo. No presente estudo, pode-se dizer que estas tendências se manifestam com os médicos identificando como problema a recusa do usuário às indicações médicas e as enfermeiras demonstrando preocupação de como informar para conseguir adesão ao tratamento. No segundo caso, parece haver mais espaço para a expressão autonômica, ainda que se lance mão da persuasão para convencer o usuário de que o profissional sabe o que é melhor para ele, graças ao fato de dominar o conhecimento técnico. 
Na mesma pesquisa de Uden e col. (1992), o enfermeiro percebe-se um "ser junto com os colegas", buscando suporte do grupo quando tenta resolver pendências éticas, em contraste com o médico que se entende um "ser isolado como um indivíduo". Esta percepção talvez possa explicar porque, no presente estudo, somente os enfermeiros manifestam sentir falta de apoio estrutural para discutir e resolver os problemas éticos. Neste sentido, Wagner e Ronen (1996) assinalam que os enfermeiros na área hospitalar se aconselham com os colegas quando estão frente a um problema ético, entretanto para os que atuam na atenção básica não fica claro este padrão. Oddi e col. (1995) defendem que estas situações representam uma carga pesada para que o enfermeiro lide com elas sozinho.

Desta forma, tornam-se pertinentes as ponderações de Robillard e col. (1989) que enfatizam a necessidade de considerar as percep̧̧ões de cada uma das várias disciplinas no reconhecimento e no manejo das questões éticas e de Oberle e Hughes (2001) que defendem um diálogo maior dentro e entre a enfermagem e a medicina sobre os aspectos éticos das situações e decisões.

\subsubsection{AS RELAÇÕES COM OS USUÁRIOS E AS FAMÍLIAS}

Na categoria "problemas éticos nas relações com os usuários e famílias" é possível, a partir de elementos em comum, agregar os achados em subgrupos menores, que são apresentados nos quadros que seguem. Neles também se indicam os enfermeiros e/ou médicos em cujos discursos se encontram os problemas listados, ou seja, os temas que conformam as unidades de registro, que são exemplificados com trechos de alguns dos depoimentos, as unidades de contexto. Os quadros, com os diferentes subgrupos, recebem uma única numeração e título, sendo diferenciados por letras, para indicarem que dizem respeito à mesma categoria. 


\section{QUADRO 7A - PROBLEMAS ÉTICOS NAS RELAÇÕES COM OS USUÁRIOS E AS FAMÍLIAS}

\begin{tabular}{|c|c|}
\hline \multicolumn{2}{|c|}{ ASPECTOS RELATIVOS Ȧ RELAÇÃO PROPRIAMENTE DITA } \\
\hline $\begin{array}{l}\text { Dificuldade em } \\
\text { estabelecer os } \\
\text { limites da relação } \\
\text { profissional - } \\
\text { usuário } \\
\text { E5, E11 }\end{array}$ & $\begin{array}{l}\text { "Para mim isso é um dilema importante. A relação mesmo, um ponto } \\
\text { assim, o limite da relação profissional - familia, profissional - } \\
\text { paciente" (E5) } \\
\text { "Você acaba sendo o profissional, o amigo, o enfermeiro da família" } \\
\text { (E11) }\end{array}$ \\
\hline $\begin{array}{l}\text { Limites da } \\
\text { interferência da } \\
\text { equipe no estilo de } \\
\text { vida das famílias } \\
\text { ou usuários } \\
\text { M12 }\end{array}$ & $\begin{array}{l}\text { "(...) Se a pessoa não enxerga aquilo, apesar de toda a } \\
\text { sensibilização, da educação que a gente faz, ela não enxergar aquilo } \\
\text { como um fator que vai levar a ter doenças? (....) eu devo invadir essa } \\
\text { casa? Nós temos esse direito? É ético esse procedimento? (M2) }\end{array}$ \\
\hline $\begin{array}{l}\text { Pré-julgamento dos } \\
\text { usuários dos } \\
\text { serviços por parte } \\
\text { da equipe } \\
\text { E2, E3, E8, E16, } \\
\text { M18 }\end{array}$ & $\begin{array}{l}\text { "(....) sem dar uma chance, a gente já tava julgando e acusando o } \\
\text { marido (....) coisa de pré-julgamento que a gente fez (....)" (E16) }\end{array}$ \\
\hline $\begin{array}{l}\text { Desrespeito do } \\
\text { profissional para } \\
\text { com o usuário } \\
\text { E2, E8, E11, M1, } \\
\text { M2, M8, M13 }\end{array}$ & $\begin{array}{l}\text { "(....) o que ele pecou mesmo foi desrespeitar o paciente (....) não teve } \\
\text { ética nenhuma na hora de tá gritando no corredor, na hora de tá } \\
\text { discutindo com a paciente (....)" (E8) } \\
\text { "a maneira como eu me comportei, botar ela pra fora da sala, ai eu } \\
\text { acho que seria um pouco até falta de ética" (M2) }\end{array}$ \\
\hline $\begin{array}{l}\text { Atitude do médico } \\
\text { frente aos valores } \\
\text { religiosos próprios } \\
\text { e dos usuários }\end{array}$ & $\begin{array}{l}\text { “(....) ele acredita que Deus vai curá-lo (....) traz isso para uma } \\
\text { consulta médica, como o médico aborda isso, se é que o médico deve } \\
\text { abordar essa questão (....) dentro de uma consulta clinica, eu acho } \\
\text { que talvez eu não tivesse esse direito de invadir esse campo (....)”. } \\
\text { (M11) } \\
\text { "eu me senti antiética (....) porque na faculdade a gente aprende que } \\
\text { não se deve colocar os seus valores morais, religiosos, de qualquer } \\
\text { ordem na balança (....) por mais que a medicina seja uma arte, você } \\
\text { tem que ser técnica (....)" (M11) }\end{array}$ \\
\hline
\end{tabular}


O PSF caracteriza-se pela busca do vínculo e responsabilização da equipe para com as famílias de sua área, estimulando-se a participação crítica nas questões de saúde da comunidade, o que por certo traz novos nuances a um problema já enfrentado pelos profissionais de saúde: o estabelecimento dos limites da relação com o usuário. Estudo realizado por Viens (1994) com um grupo de enfermeiros que atua na área de atenção básica, em grandes cidades do oeste norte-americano, indica que o relacionamento com o usuário tem um significado importante para estes profissionais, tornando-se mais significativo na medida em que o contato perdura ao longo do tempo ou quando o usuário apresenta necessidades prementes. Esta relação também é apontada, na pesquisa citada, como um catalisador de problemas éticos.

Wellard (1992) entrevistando enfermeiros de serviços de diálise, na comunidade de Victoria, Austrália, onde a exemplo da USF as relações com os usuários são mais duradouras e com contatos mais constantes, identifica que o início deste relacionamento é visto como "muito dificil". Conflitos surgem porque os usuários não acreditam que os enfermeiros tenham a expertise requerida para prover o cuidado adequado, tendo estes que provar sua habilidade antes de gozarem da confiança dos primeiros. Com o decorrer do tempo, este conflito se resolve, a relação distante e de desconfiança dá lugar para a amizade e o apoio mútuo, então, o dilema para os enfermeiros passa a ser como responder profissionalmente sendo um amigo.

Os limites da interferência da equipe no estilo de vida das famílias ou dos usuários, ou seja, em que medida os profissionais de saúde podem ser coercitivos acerca das opções terapêuticas e das mudanças de estilo de vida constitui, segundo Brody (1983a), tema central das questões éticas envolvidas na atenção à saúde da família. De acordo com o autor, uma forma peculiar de coerção pode ser exercida pelos profissionais de saúde, especialmente os médicos, na qual estes, com base na sua autoridade, manipulam o usuário através de apresentações enviesadas ou omissão dos dados, opções ou informações. Quando o profissional meramente descreve os cursos alternativos de ação de maneira neutra de valores, permitindo que o usuário faça sua opção, a coerção fica explicitamente ausente. Porém, sabe-se que 
comunicação com tal neutralidade torna-se impossivel na prática e o mais freqüente é o profissional explanar ao usuário as várias opções, tentando persuadi-lo a aceitar a que, na opinião do profissional, atende melhor seus interesses.

Em estudo que busca conhecer as considerações éticas de enfermeiros visitadores na Holanda, os entrevistados ponderam que têm que se adaptar ao modo de vida do usuário para minimizar as conseqüências negativas dos aspectos intrusivos, inevitáveis de seu trabalho. Assim, frente a uma divergência de opiniões com o usuário ou a familia, devem tentar chegar a um acordo, imediatamente ou no futuro, através da explicação das conseqüências do curso de ação escolhido pelo usuário e das razões pelas quais o enfermeiro escolhe outra alternativa. Devem ser capazes de oferecer sugestões e fazer ofertas sem pressionar, tentando ganhar confiança para que o usuário possa manifestar suas objeções, medos ou preocupações e então o ouçam, dêem informação ou o apóiem quando quiser discutir a questão novamente (GREMMEN 1999).

Esta tendência de respeitar as escolhas dos usuários e famílias, mas levantando questões acerca das opções, também aparece em investigação envolvendo 674 médicos de família dos Estados Unidos, Inglaterra e Canadá que admitem discutir o estilo de vida dos usuários, sem interferir (HOFFMASTER e col. 1992). Enfermeiros de serviços extra-hospitalares de British Columbia, Canadá, revelam que as situações mais dificeis que enfrentam na sua prática diária envolvem determinar os direitos de adultos e adolescentes permanecerem em risco (DUNCAN 1992).

Embora o tempo decorrido possa impor limites à consideração de seus resultados, vale citar que pesquisa realizada há mais de 20 anos, com professores do Departamento de Medicina da Família da Universidade Western Ontário, Canadá, sugere que a disponibilidade ou não para interferir no estilo de vida das pessoas varia a depender das conseqüências para a saúde e do comportamento que deve ser alterado. A maioria dos respondentes $(84,3 \%)$ está preparada para tentar mudar 0 estilo de vida de um usuário quando este configura um potencial dano a sua saúde. 
Entretanto, poucos se sentem preparados para tentar esta alteração quando a questão envolve problemas como a interrupção de uma gestação, contracepção permanente, fim de um casamento, o uso de drogas ilícitas ou casos extraconjugais, situação em que $86 \%$ dos entrevistados afirma que raramente interferiria. Exceção deve ser feita aos médicos mais velhos, que além de mais propensos a coagir as pessoas para aceitarem um plano de tratamento ou uma internação, também tendem mais a tentar alterar o estilo de vida dos usuários no que diz respeito a práticas sexuais, casos extraconjugais e uso de drogas ilicitas (CHRISTIE e col. 1983).

Em relação ao pré-julgamento do usuário, a influência dos critérios, como idade, gênero, responsabilidade social, condição econômica e, especialmente, estilos de vida não aceitos socialmente sobre as decisões clínicas e de microalocação de recursos em saúde tem sido abordada em diferentes estudos, realizados em distintos países. Jonsen e col. (1999) mencionam pesquisa desenvolvida, em 1987, nos EUA que mostra um número expressivo de médicos que estigmatiza os homossexuais, demonstrando menos vontade de atendê-los. Também apontam haver discriminação em relação ao gênero, com os médicos do sexo masculino tendendo a desvalorizar as queixas de saúde das mulheres.

Estudos feitos no contexto brasileiro (FORTES 2000; FORTES e col. 2001) assinalam o peso da influência desses critérios na microalocação de recursos escassos em saúde. Na primeira pesquisa (FORTES 2000), realizada com acompanhantes de usuários de um hospital público de um município da Grande São Paulo, na qual thes é solicitado que em uma situação simulada hipoteticamente escolham entre duas mulheres com problemas hepáticos, uma devido ao alcoolismo e outra à hepatite, ambas sendo atendidas no mesmo serviço de emergência que conta apenas com um leito disponível para internação e em igual condição clínica necessitando ser admitidas, fica nítida a opção pela mulher com doença relacionada à hepatite, escolhida por $82.3 \%$ das pessoas, ao passo que optam pela alcoólatra somente $14.4 \%$. No outro estudo (FORTES e col. 2001), o mesmo cenário hipotético é apresentado a estudantes do primeiro e do último semestre do curso de graduação em administração 
hospitalar e a tendência se mantém nos dois grupos que, respectivamente, têm $92.2 \%$ e $64 \%$ das opções para a mulher com hepatite.

A valoração negativa de estilos de vida não saudáveis parece enfatizar a responsabilidade individual pela saúde e, assim, as pessoas que autonomamente escolhem estilos de vida não saudáveis poderiam e, muitas vezes, deveriam ser preteridas em situações de escassez de recursos se os disputassem com quem conduz sua vida por alternativas consideradas favoráveis à manutenção da saúde. A argumentação está no fato dos comportamentos individuais não saudáveis potencialmente trazerem prejuizos também para terceiros e à sociedade como um todo, principalmente ao onerar os custos da atenção em saúde, sendo injusto o uso dos recursos da coletividade pelos que orientam sua vida por estilos não saudáveis, em detrimento de quem sempre se 'esforçou' para manter uma vida saudável.

Neste sentido, Jonsen e col. (1999) ponderam que os profissionais de saúde por certo têm suas crenças e valores que podem conduzir a julgamentos enviesados e discriminatórios contra algumas pessoas ou grupos sociais, afetando, conseqüentemente, as decisões clínicas. Entretanto, são contundentes ao afirmar que não é prerrogativa dos profissionais fazer essas espécies de julgamentos no contexto da atenção à saúde, pois todos devem ser atendidos em função de suas necessidades e não de seu valor ou mérito social. Alertam que atualmente estes preconceitos são menos explícitos, mas não menos perigosos e devem ser identificados para serem eliminados das decisões clínicas. Parece que a adoção destes critérios, além de soar como culpabilização da vítima, desvia a discussão de seu foco principal, os determinantes e condicionantes sociais do processo saúde-doença.

Ver-se em uma situação de pré-julgamento do usuário também pode gerar insatisfação e desconforto para os profissionais de saúde. Os resultados do estudo com enfermeiros que atuam na atenção básica, nos EUA, mostram que a noção de respeito às pessoas inclui, além das questões relativas à autonomia e reciprocidade, "não julgar" (VIENS 1994). Esta sensação de incômodo aparece na presente 
pesquisa, como se pode observar pela sua repetição em diversos trechos do discurso de um dos enfermeiros:

“(...) pré-julgamento que a gente fez, eu acho horrivel, eu me senti muito culpada (....) me senti muito mal de julgar (....) acho que poderia ter sido feito de uma outra forma pra que (....) doesse menos pra equipe, porque na verdade não doeu pra eles isso que a gente fez, doeu para a gente, né, fez a gente ficar sem dormir, naquela ansiedade toda (....)" (E16)

"(...) eu fiquei pensando: 'como que a gente tem essa capacidade de julgar, de acusar e criou um mal estar dentro da equipe (....)" (El6)

“(....) foi uma situação que me fez sentir um pouco dona do poder, um pouco ... essa coisa de ... sabe, você tá lá e eu tô aqui, eu sei de tudo, você não sabe de nada. Me fez repensar muito sobre isso. Ah! Eu não sei bem se foi uma falha ética, técnica, mas foi uma situação que fez eu me sentir muito mal." (El6)

O trato rude e ofensivo das equipes de saúde para com os usuários também aparece em outros estudos acerca de problemas éticos na atenção básica realizados em Israel (WAGNER e RONEN 1996) e nos EUA (ROBILLARD e col. 1989). Neste último país, outra pesquisa feita em uma cidade litorânea do sul da Califórnia, com mulheres entre 18 e 60 anos de idade, de populações vulneráveis (idosas, latinoamericanas que não falavam inglês, sem teto, vítimas de violência doméstica etc.) revela que além de experimentarem dificuldades no acesso aos cuidados médicos, são alvo de falta de respeito quando superam as barreiras e conseguem atendimento (MORROW 1997). Da mesma forma, estudos brasileiros que investigam as ocorrências registradas por comissões de ética de enfermagem de hospitais das cidades de Ribeirão Preto e São Paulo, denotam a existência deste problema ético no contexto hospitalar (DUCATI e BOEMER 2001; FREITAS 2002). Neste sentido, é oportuno assinalar que Wagner e Ronen (1996) ao compararem os dados obtidos nos 
serviços de atenção básica com os dos hospitais, em Israel, encontram uma maior freqüência deste quesito nos últimos.

A formação do vínculo entre a equipe de saúde e os usuários e/ou famílias, que está no cerne da proposta do PSF, pressupõe uma relação de diálogo que se estabelece entre pessoas que se reconhecem e respeitam-se como sujeitos. Um comportamento marcado pela violência e agressividade se não inviabiliza, ao menos ameaça a relação de vínculo e de co-responsabilização pela saúde dos usuários. Merece questionamento se as raízes desse problema ético não estariam relacionadas ao valor social atribuído à população usuária da unidade de saúde ou, ainda, ao fato dos trabalhadores que estão no PSF considerarem que o usuário não tem outras alternativas de recursos, como mostra estudo sobre acolhimento realizado no Projeto Qualis/PSF (ACCASTO e col. 2001).

O problema ético do desrespeito parece trazer à tona a imprevisibilidade de resultados que é inerente às relações que marcam o encontro entre usuários e trabalhadores, no qual entra em jogo uma disputa de interesses. De um lado o usuário busca a resolução de um problema de saúde que considera importante e do outro, o trabalhador, muitas vezes, mantém-se preso a procedimentos, normas e rotinas do serviço ou ainda a seu entendimento técnico do que é melhor para o usuário. Neste desencontro de necessidades e interesses, a negociação é imprescindível, pois nem sempre o carecimento do usuário é interpretado como um problema pelo profissional e/ou para o serviço de saúde (MATUMOTO 1998; MATUMOTO e col. 2001; SILVA e DALMASO 2002).

Como assinalam Chiesa e Veríssimo (2001), a comunicação é indispensável para a assistência à saúde, pois, além de principal meio de veiculação do processo educativo, constitui-se recurso para estabelecer a confiança e a vinculação do usuário à equipe e ao serviço. Os enfermeiros devem incluir entre seus conhecimentos técnicos os relativos à comunicação, entretanto a tecnologia das relações é uma das mais complexas por abranger não somente conhecimentos, habilidades $e$ comportamentos, mas, requer, sobretudo, atitudes. Continuam as autoras afirmando 
que a comunicação na atenção à saúde configura uma ação intencional, dirigida e orientada para um interesse concreto, sendo "algo que se constrói", com base na escuta do outro para compreender quais são suas crenças, sua situação e suas possibilidades, com vistas a poder atuar conjuntamente. Esta abordagem dialógica e emancipatória tem como um dos seus pressupostos acreditar que todas as pessoas têm direito a escolher o caminho mais apropriado para promover, manter e recuperar sua saúde.

Certas seitas religiosas impõem crenças sobre saúde, doença e tratamentos, podendo influenciar as preferências dos usuários. Muitas vezes, estas crenças são sutis e passam desapercebidas pelos profissionais de saúde, gerando mal entendidos que são agravados pelas barreiras de comunicação. Os conflitos usualmente surgem quando as crenças religiosas ou culturais configuram motivos de recusa de um cuidado médico, especialmente quando este é importante ou pode salvar a vida da pessoa (CONNELLY 2000).

Jonsen e col. (1999), além de considerarem tais escolhas imprudentes ou perigosas, ponderam que o desconhecimento das crenças e costumes por parte dos profissionais de saúde pode levá-los a questionar a capacidade mental dos usuários e suas familias. Entretanto, o simples fato de aderir a uma denominação religiosa incomum, por si só não constitui evidência de incapacidade. $\mathrm{Na}$ ausência de sinais clínicos de incapacidade, tais pessoas devem ser consideradas como capazes de escolher. Na medida do possível, em uma negociação, o usuário e o profissional devem descobrir objetivos em comum e estabelecer uma estratégia mutuamente aceita para atingi-los .

A equipe de PSF deve instruir-se quanto às crenças mais comuns na comunidade onde atua, lançando mão, se necessário, de mediadores como clérigos ou pessoas habilitadas que possam explicá-las e comunicar-se com quem as professa. A relação de vínculo e responsabilização pressupõe ultrapassar as informações de cunho biológico. O respeito pelas pessoas, que está no cerne do relacionamento vincular, requer que estas sejam respeitadas não como indivíduos abstratos, mas 
como pessoas formadas e integradas nos valores de suas culturas e religiões. Entretanto, a formação dos profissionais de saúde, especialmente a médica, centrada principalmente nos fatos científicos não favorece a consideração destas questões, gerando desconforto em quem lhes atribui importância e os inclui na abordagem clínica, como se pode observar pelo depoimento do médico que está em destaque no quadro anterior.

Neste sentido, vale citar que os professores do Departamento de Medicina da Família da Universidade Western Ontário, quando perguntados se contariam aos usuários seus próprios valores ao aconselhá-los, 54,6\% responderam que improvavelmente ou raramente; $33 \%$ provavelmente ou usualmente e $12 \%$ ficaram em posição intermediária (CHRISTIE e col. 1983). 
QUADRO 7B - PROBLEMAS ÉTICOS NAS RELAÇÕES COM OS USUÁRIOS E AS FAMÍLIAS

\begin{tabular}{|c|c|}
\hline \multicolumn{2}{|c|}{ ASPECTOS RELATIVOS AO PROJETO TERAPẾUTICO } \\
\hline $\begin{array}{c}\text { Indicações clínicas } \\
\text { imprecisas } \\
\text { E3, E19 }\end{array}$ & $\begin{array}{l}\text { "(...) foi (...) uma conduta (...) eu não posso dizer errada (....) mas } \\
\text { (....) era uma conduta que num não dava pra ter tomado, tinha que } \\
\text { ser outra (....)" (E19) }\end{array}$ \\
\hline $\begin{array}{l}\text { Prescrição de } \\
\text { medicamentos que o } \\
\text { usuário não poderá } \\
\text { comprar } \\
\text { E11 }\end{array}$ & $\begin{array}{l}\text { "Se eu for prescrever uma pomada (....) eu tenho que saber se eu não } \\
\text { tenho no posto e se ela tem condições de comprar. Que não adianta } \\
\text { eu fazer a receita, se ela guardar e não usar." (E11) }\end{array}$ \\
\hline $\begin{array}{c}\text { Prescrição de } \\
\text { medicamentos mais } \\
\text { caros com eficácia } \\
\text { igual a dos mais } \\
\text { baratos } \\
\text { E11 }\end{array}$ & $\begin{array}{l}\text { "(....) essa pomada é mais cara, e mesmo que você tenha condições, } \\
\text { se você pode usar um produto mais barato que vai surtir o mesmo } \\
\text { efeito, porque você vai usar o mais caro, né?!"(E11) }\end{array}$ \\
\hline $\begin{array}{l}\text { Solicitação de } \\
\text { procedimentos pelo } \\
\text { usuário }\end{array}$ & $\begin{array}{l}\text { "Tem mais um caso de um paciente que (....) é portador de HIV e } \\
\text { (....) já foi repetido } 3 \text { ou } 4 \text { vezes o exame dele (....) mas ele quer que } \\
\text { repita de novo, então vai ser feito novamente o exame dele (....)" } \\
\text { (E11) } \\
\text { "Outra coisa, o raio X, elas querem o raio X o tempo todo e eu me } \\
\text { recuso a pedir raio X porque eu acho que está expondo a criança à } \\
\text { radiação desnecessária." (M2) }\end{array}$ \\
\hline $\begin{array}{c}\text { Solicitação de } \\
\text { procedimentos por } \\
\text { menores de idade sem } \\
\text { autorização ou } \\
\text { conhecimento dos } \\
\text { pais } \\
\text { M13 }\end{array}$ & $\begin{array}{l}\text { "(...) pode ou não pode uma pessoa menor vir e pedir um teste, junto } \\
\text { com uma outra, maior de } 21 \text { anos, que é simplesmente uma parente } \\
\text { (....) até hoje ficou meio assim: deve ou não deve fazer o exame?" } \\
\text { (M13) }\end{array}$ \\
\hline $\begin{array}{l}\text { Recusa do usuário } \\
\text { às indicações } \\
\text { médicas } \\
\text { M2, M11 }\end{array}$ & $\begin{array}{l}\text { "(....) eu acho meio dificil (....) você tenta atende, tenta ajudar, tenta } \\
\text { fazer e um paciente se recusa (....)" (M2) } \\
\text { "(....) no fundo eu não aceitei perder! Não aceitei que ele pudesse } \\
\text { dizer para mim: 'olha, eu não quero me tratar'. Não, prá mim, ele } \\
\text { tinha que querer!" (M11) }\end{array}$ \\
\hline
\end{tabular}


Discutindo a ética clínica, Jonsen e col. (1999) alertam que, muitas vezes, a análise de um problema ético deveria começar com respostas à questão "quais são as indicações médicas para o tratamento" e não com a pergunta "terá o doente direito a recusar um tratamento". Isto porque boa parte dos problemas éticos pode ser evitada quando as decisões terapêuticas baseiam-se em indicações médicas claras. Entretanto, a incerteza sobre a matéria clínica do caso é um fator para emergência de pendências éticas que podem ser rapidamente resolvidas ou, às vezes, tornarem-se grandes obstáculos para a condução da assistência.

O estudo de Wagner e Ronen (1996), em Israel, também aponta a imprecisão nas indicações clínicas como situações potencialmente geradoras de problemas éticos para os enfermeiros, tanto na atenção básica como nos hospitais. Administrar tratamentos percebidos como errados ou inadequados é citado como problema por $52 \%$ dos enfermeiros da área de atenção básica e $67,9 \%$ dos que atuam no contexto hospitalar e dar tratamentos de valor questionável é mencionado por $49,8 \%$ e $58,7 \%$ dos entrevistados, respectivamente. A discordância de indicações entre profissionais ainda aparece como um problema ético em pesquisas realizadas com enfermeiros de diferentes tipos de serviços de saúde na Holanda e médicos de diferentes especialidades nos EUA (PELLEGRINO e col. 1985; WAGNER e RONEN 1996; VAN DER AREND e REMMERS-VAN DER HURK 1999).

No tocante à solicitação de procedimentos pelos usuários, os resultados do estudo de Robillard e col. (1989) também mostram esta questão como um problema ético percebido tanto pelos médicos como pelos outros profissionais de saúde que atuam na atenção básica. A primeira vista parece que os usuários têm o direito de, autonomamente, questionar o projeto terapêutico proposto junto à equipe, entretanto, este talvez não seja o ponto fulcral já que, como afirma Brett (2000), na maioria dos casos, os pedidos dos usuários poderiam ser discutidos com mais facilidade se a prática de compartilhar a tomada de decisão norteasse o encontro que se estabelece entre estes e os profissionais de saúde. 
Como ponderam Jonsen e col. (1999), a autoridade das "preferências do paciente" não é ilimitada, sendo as obrigações éticas dos profissionais de saúde definidas pelos objetivos da intervenção proposta e os desejos dos usuários. A equipe de saúde não está obrigada a realizar atos que ultrapassem ou sejam contraditórios com os objetivos da medicina, mesmo que o usuário assim o solicite. Em outras palavras, os autores defendem que os usuários não têm direito de pedir aos profissionais de saúde que procedam a atos que são contra-indicados, desnecessários, pouco "ortodoxos", ilegais ou eticamente inadequados. Os profissionais de saúde não podem ministrar procedimentos diagnósticos e/ou terapêuticos sem o consentimento do usuário ou seu responsável, quando for o caso, mas podem abster-se de atos que considerem técnica ou eticamente errados.

Assim, parece pertinente a ponderação do médico ao justificar sua recusa para atender uma solicitação do responsável de um usuário:

“(....) eu me recuso a pedir raio $X$ porque eu acho que está expondo a criança à radiação desnecessária. Então, na medida que eu recuso a fazer isso ai, eu tô quebrando a ética? Não, eu estou sendo coerente com uma coisa que é certa, não vou expor a criança a uma radiação semanal sem necessidade (....)" (M2)

No outro discurso exemplificado no quadro, o do E11, o usuário pede uma nova coleta de exame para HIV no que é atendido em nome dos prováveis danos que a recusa poderia trazer, no entanto, é sabido que muitas equipes de PSF trabalham com restrição de cotas para os encaminhamentos laboratoriais, sendo as dificuldades no acesso a exames complementares um dos problemas éticos apontados pelos entrevistados. Parece pertinente para o caso em tela a recomendação que fazem Doukas e McCullough (1996) para profissionais que atuam na atenção básica, que explorem as solicitações dos usuários, verificando se há crenças resultantes de informações pobres ou equivocadas que poderiam ser corrigidas por ações educativas e averiguando se existem preocupações, histórias e valores a fim de trabalhar com o usuário as possibilidades de outras alternativas, além da que está sendo requerida. 
Ainda para situações como esta, Brett (2000) afirma que, ocasionalmente, os beneficios de renovar a confiança do usuário que está em dúvidas sobre seu diagnóstico justificam a realização de exames mesmo que desnecessários e, quando a incerteza do usuário for sobrepujante, vale até onerar injustamente o sistema de saúde. Essa visão parece centrar-se muito no âmbito individual e dos procedimentos técnicos, talvez com excessiva valorização do direito de livre escolha que marcam o setor saúde nos EUA. Uma atenção que visa a autonomização e a promoção da cidadania dos usuários, além da co-reponsabilização pelas questões de saúde locais como é meta do PSF, mais bem terá que ponderar a recusa de procedimentos desnecessários em nome de uma distribuição justa de escassos recursos como eticamente justificável. Assim, valeria perguntar se não seria o caso de discutir com o usuário as implicações de sua solicitação para as demais pessoas atendidas pela equipe, buscando outras formas de apóia-lo no processo de enfrentamento de sua condição que ultrapassem a esfera do biológico e da realização de procedimentos médicos.

Como argumenta Duncan (1992) ao discutir os desafios éticos da prática da enfermagem comunitária em Bristish Columbia (Canadá), a defesa e o desenvolvimento da comunidade requerem que os enfermeiros que atuam na atenção básica centrem-se nas condições que determinam a saúde, encontrando maneiras de fortalecer as habilidades dos usuários para assegurar seus direitos e avaliarem a qualidade dos serviços. No entendimento da autora, um aumento na participação dos usuários em seu cuidado, tanto no âmbito individual como no planejamento da saúde da comunidade, aumentaria a resposta do sistema de saúde às necessidades dos usuários, principalmente os que estão em situação de alto risco.

Nesse sentido, merecem destaque os problemas éticos que decorrem de preocupações com as condições dos usuários para adquirirem os medicamentos prescritos, promovendo um diálogo que visa discutir a medicalização das carências em saúde e a relação entre eficácia e preço dos medicamentos. Este tipo de conversa parece ir além das informações usuais de cunho biológico, avança para uma troca de 
valores e concepções, o que denota responsabilização e favorece a autonomização e a construção da cidadania do usuário, em consonância com os pilares e diretrizes do SUS e do PSF.

Pesquisa interdisciplinar realizada na Escócia com uma amostra representativa da diversidade da população usuária dos serviços de saúde daquele país aponta a prescrição de medicamentos genéricos mais baratos, como uma área especialmente problemática, pois a falta de informação dos usuários gera a falta de confiança na eficácia destes produtos (HILL e col. 1988).

Frente a esta observação, parece oportuno mencionar que durante a realização das entrevistas para o presente estudo, a pesquisadora presenciou situação contrária, com o usuário solicitando a substituição da prescrição de um medicamento de marca por um genérico e o médico (M2) se recusando, sob alegação de que não prescreve este tipo de medicação por considerá-la "injusta" para com a indústria farmacêutica que investe no desenvolvimento das drogas. Neste caso, o equívoco e a falta de informação, além da análise míope das questões relativas às políticas de medicamentos, aparentemente, são do profissional de saúde e não do usuário.

Sem esquecer as diferenças de cada país, tanto em relação ao sistema de saúde como no que diz respeito às condições sócio-econômicas da população, cabe marcar que estudos norte americanos apontam a insuficiência de recursos financeiros dos usuários entre as questões éticas mais freqüentes na atenção à saúde praticada fora do contexto da internação hospitalar (AROSKAR 1989; ROBBILARD e col. 1989; HADDAD 1992; VIENS 1994; CONNELLY 1998). Num destes estudos, o realizado por Robillard e col. (1989), a restrição financeira dos usuários enquanto fator de não adesão ao tratamento é mencionada como problema ético por $70,8 \%$ dos 391 médicos e $78,3 \%$ dos 311 demais profissionais.

A recusa de tratamento ocorre com freqüência na atenção básica e inclui uma ampla variedade de intervenções, desde medidas de manutenção da saúde, como imunização, colpocitologia, mamografia até exames diagnósticos, medicações e 
terapias. Dentre os fatores intervenientes para isto, merece destaque o maior controle do usuário, que ao ser capaz de exercitar sua liberdade de escolha, em certa medida está mais imune à intimidação imposta pela gravidade da doença e à expertise dos profissionais, além de ter mais oportunidades para mudar de idéia, mesmo com o tratamento já iniciado. Isto confere grande importância a seu relacionamento com a equipe de saúde, devendo-se propiciar, através de um bom processo de comunicação, espaço para que o usuário seja compreendido em sua singularidade, com sua história única, reações próprias, crenças, costumes, preferências, decisões e com os pontos de divergência sendo abertamente discutidos. Além disso, o usuário precisa entender o que a equipe de saúde está recomendando e porque, pois isto também contribui para conformar uma recusa livre e esciarecida (BRODY 1989; CONNELLY 1998; 2000).

Quando o usuário recusa uma intervenção recomendada, seja uma medicação, uma consulta ou um procedimento diagnóstico, o profissional de saúde se vê frente a um conflito entre sua avaliação e os desejos do primeiro, o que pode lhe causar raiva, frustração e desinteresse, especialmente se a escolha the parecer irracional. A equipe pode não compreender as razões do usuário para a recusa e não ser capaz de aceitála.

Estudo realizado no Projeto Qualis/PSF, do Município de São Paulo, mostra que a equipe de saúde da família valoriza as pessoas que fazem acompanhamento sem faltas e seguem a prescrição. $O$ reconhecimento ocorre quando as normas estabelecidas para o cuidado à saúde são seguidas. A dificuldade para cumprir o tratamento indicado é entendida como resistência dos usuários, que podem ser rotulados de "não aderentes", "resistentes" ou "teimosos". A simples falta do usuário a atividades agendadas já é vista como desvalorização do trabalho e do empenho da equipe, não havendo reflexão acerca dos motivos da falha na adesão ou de como desenvolver outras estratégias e formas de diálogo com o usuário que tem necessidades, concepções de saúde e tratamento diferentes das defendidas pela equipe. Ao contrário, nas atividades educativas destacam-se as ações de tipo mais impositivo ou, até mesmo, de cunho autoritário, restringindo-se as possibilidades de 
conversa que resultem na exposição e confrontação de valores e na negociação de alternativas (SILVA e DAMASO 2002).

Essa qualificação pela não adesão ao tratamento também pode ser denotada no depoimento de um dos enfermeiros entrevistados ao se referir a um usuário diabético que tem variações constantes de seu nível de glicemia:

\section{"E ela já botou na cabeça dela: 'ah! 300 de glicemia tá bom, eu não sinto nada! (....) Ela é rebelde" (E11)}

A atitude destas equipes parece ir de encontro às recomendações de Connelly (1998) para a tomada de decisão de profissionais de saúde que atuam na atenção básica. Adverte a autora, que estes devem explorar a recusa do usuário, incluindo possibilidades emocionais, como medo ou ansiedade sobre os procedimentos prescritos. Os profissionais devem ser habilidosos para encorajar o usuário a contar sua história, abrindo a interação para uma relação ampliada e expansiva, lançando mão de questões abertas, como "conte-me sobre sua dor nas costas" ao invés de "quando sua dor nas costas começou?". Ouvir ativamente configura outra característica chave desta abordagem, para que tanto quem conta, como quem ouve, possam esclarecer, discutir e descrever repetidamente a história, com vistas a acurar a informação. A tomada de decisão esclarecida virá desse tipo de discussão que possibilita uma resolução bem deliberada e cuidadosa. É claro que isto é impossivel sem expertise dos profissionais de saúde para se comunicarem com os usuários e/ou as famílias.

Neste sentido, vale lembrar a observação de Jonsen e col. (1999) acerca da pobreza dos métodos de comunicação e dos poucos esforços que se têm desenvolvido para ultrapassar as barreiras da compreensão. Também é oportuno mencionar que os resultados de Oberle e Hughes (2001) em relação às percepções de enfermeiros e médicos sobre o fim de vida apontam a comunicação como um tema distinto que perpassa os temas contextuais encontrados e, conseqüentemente, uma comunicação efetiva é apresentada pelos dois grupos como solução para muitos dos 
problemas éticos que enfrentam, tanto na relação entre os profissionais como com os usuários e famílias.

Não é raro que os profissionais de saúde ponham em questionamento a competência dos usuários para decidir ou compreender as informações que lhes são transmitidas quando estes recusam as intervenções indicadas, particularmente se o tratamento for para uma condição que ameaça a vida. Em geral, os profissionais de saúde reagem com uma tentativa agressiva de convencê-los da necessidade do tratamento. Parece, então, que tanto médicos como enfermeiros deveriam aprender a estar alertas para suas próprias atitudes e valores e serem cautelosos para não impôlos aos usuários e/ou famílias de quem cuidam, estando preparados para aceitar a vontade destes, ainda que não estejam de acordo com a sua própria opinião. Da mesma forma, a aceitação cega de qualquer solicitação de intervenção, o desrespeito da recusa sem uma explanação ou negociação pode minar a liberdade do usuário, levar à desumanização da assistência, além de consistir em falso respeito à autonomia das pessoas (SEARIGHT e BARBARASH 1994; DOUKAS e MCCULLOUGH 1996; RICHTER e EISEMANN 2000).

Parece claro, então, que a recusa de indicações médicas consiste ocorrência comum na atenção básica, representando um desafio aos profissionais de saúde. A despeito das conseqüências, antes de acatar ou rejeitar a opção do usuário, a equipe de PSF deve rever a interação entre ambos a fim de garantir que a recusa seja esclarecida, dando conta de aspectos relativos à quantidade e qualidade da informação fornecida, à compreensão do usuário incluindo as conseqüências da recusa, a sua capacidade para decidir e liberdade para uma escolha voluntária. Além disto, o reconhecimento das razões para a recusa, freqüentemente ajuda os profissionais de saúde a localizarem a situação no contexto das singularidades do usuário e sua familia, compreendendo-o melhor. Circunstâncias específicas podem influenciar, como as crenças religiosas, culturais ou o estado mental do usuário. Quanto maior o risco ou piores as conseqüências da recusa, mais intenso o desafio para os profissionais determinarem se aceitam ou não a recusa do usuário (CONNELLY 2000). 
A solicitação de procedimentos por menores de idade sem autorização ou conhecimento dos pais, tem implicações éticas e legais. Neste estudo, sem atribuir nenhuma ordem de prioridade aos dois pontos, mas simplesmente pelas questões do escopo da presente pesquisa, discutir-se-ão apenas as primeiras.

Como afirmam Ross e Lantos (2000), com base nos aspectos legais, até recentemente as crianças eram de antemão presumidas como incompetentes para decidir, cabendo considerar exclusivamente as escolhas de seus pais ou responsáveis. Entretanto, atualmente já são comuns os movimentos para se reconhecer a competência da criança para decidir em algumas situações, argumentando-se que às mais maduras, especialmente aos adolescentes, seja permitido fazerem suas próprias escolhas sem a permissão ou o conhecimento dos pais. Há quem contra argumente, afirmando que a competência por si só não é o único fator a determinar a participação da criança no processo de tomada de decisão das questões relativas a sua saúde. Estes defendem que os pais têm o direito moral de exercer um papel significante ou mesmo exclusivo nas decisões sobre os cuidados de saúde de seus filhos, acreditando que estes sempre agirão no melhor interesse da criança, e o que decidirem será bom para ela, os pais e a sociedade.

Esta percepção do conflito entre o direito dos pais e dos adolescentes fica patente nos trechos do depoimento de um dos médicos entrevistados:

"Então a opinião minha era o seguinte: a mãe é responsável pela menina, ela teria direito ao exame, só que o exame foi feito de uma maneira escondida da mãe pela filha, né?!" (M13)

“(....) eu poderia entregar pra mãe? Poderia sem a filha? Mas, a filha que queria saber, como seria a mãe em relação à filha pra entregar esse exame, porque mexeu com a virgindade da menina! $E$ isso pra mãe é uma situação ..." (M13) 
Muitos profissionais optam por um caminho entre os dois extremos e tentam incluir as crianças quando possível e da maneira que lhes parece mais factível para o momento. $\mathrm{O}$ direito da criança de participar das decisões aumenta na medida em que amadurece e desenvolve sua capacidade de compreender e analisar a informação que necessita para decidir. Entretanto, quanto mais graves as conseqüências da decisão, mais os profissionais de saúde deveriam tender a seguir a opinião dos pais quando esta difere das da criança (ROSS e LANTOS 2000).

A prática de considerar as opiniões dos menores de idade segundo sua capacidade decisional, conhecida como "maioridade sanitária" é reconhecida pelo atual Código de Ética Médica, no Brasil. Contudo, no exercício diário da profissão, esta noção ainda não é muito disseminada, gerando dúvidas e conflitos para os profissionais de saúde que, muitas vezes, optam pela segurança dos parâmetros legais (FORTES 1998). 


\section{QUADRO 7C - PROBLEMAS ÉTICOS NAS RELAÇÕES COM OS USUÁRIOS E AS FAMÍLIAS}

\begin{tabular}{|c|c|}
\hline \multicolumn{2}{|r|}{ ASPECTOS RELATIVOS À INFORMAÇÃO } \\
\hline $\begin{array}{l}\text { Como informar o } \\
\text { usuário para } \\
\text { conseguir sua } \\
\text { adesão ao } \\
\text { tratamento } \\
\text { E11, E14, E16, } \\
\text { E18 }\end{array}$ & $\begin{array}{l}\text { "(....) vai ter muitos casos éticos onde você, a forma com que } \\
\text { você fala com eles faz com que eles venham ou não ... pra cá, } \\
\text { pras consultas." (E11) } \\
\text { "(....) eticamente eu não posso chegar, eu acredito, chegar pra } \\
\text { paciente e falar assim: 'se você não fizer isso, isso e isso, você } \\
\text { vai morrer!'. Você tem que saber colocar as palavras, não é?!" } \\
\text { (E11) }\end{array}$ \\
\hline $\begin{array}{l}\text { Omissão de } \\
\text { informações ao } \\
\text { usuário } \\
\text { E10, E11 }\end{array}$ & $\begin{array}{l}\text { “(...) eu não posso omitir um resultado, eu acho que (....) é um } \\
\text { direito (....) do paciente de saber o resultado de um exame, né, e } \\
\text { até de pegar, é dele, então eu taria negando esse direito pra } \\
\text { ele, omitindo o resultado desse exame (....)" (E11) }\end{array}$ \\
\hline $\begin{array}{l}\text { Acesso dos } \\
\text { profissionais de } \\
\text { saúde a } \\
\text { informações } \\
\text { relativas à } \\
\text { intimidade da } \\
\text { vida familiar e } \\
\text { conjugal E5, M14 }\end{array}$ & $\begin{array}{l}\text { "(....) de repente surge no meio de uma consulta (....) histórias } \\
\text { de infidelidade conjugal (....) de gravidez indesejada ou de } \\
\text { dúvida de paternidade (....)" (E5) } \\
\text { "Você entra tanto na vida dessas pessoas que (....) não sei se } \\
\text { eles ficam sabendo, quanto que a gente sabe deles (....)" (M14) }\end{array}$ \\
\hline $\begin{array}{l}\text { Discussão de } \\
\text { detalhes da } \\
\text { situação clínica do } \\
\text { usuário na sua } \\
\text { frente } \\
\text { M14 }\end{array}$ & $\begin{array}{l}\text { “(...) por exemplo (....) um paciente no curativo, ou com uma } \\
\text { lesão, vamos supor, é ... uma neoplasia (....) a auxiliar chega e } \\
\text { chama a gente e (....) não tem o cuidado de falar, né, de outra } \\
\text { forma, ou ... talvez até fora da situação (....) acaba falando lá } \\
\text { na frente e a gente não tem como falar 'Para!'(....)” (M14) }\end{array}$ \\
\hline
\end{tabular}


A omissão de informações e a revelação da verdade para o usuário também aparecem como problemas éticos importantes nas pesquisas realizadas em serviços de saúde não hospitalares do sul da Austrália e do Estado da Virgínia, EUA (CONNELLY e DALLEMURA 1988; MAYER-BRAUNACK 2001). No estudo de Wagner e Ronen (1996) com enfermeiros israelenses de hospitais e de serviços comunitários (incluindo atenção básica), as situações que envolvem dar ao paciente informações inadequadas sobre seu diagnóstico são vistas como potencialmente geradoras de problema ético por 14,8\% dos 506 que trabalham na área hospitalar e $12,3 \%$ dos 239 que atuam na comunidade. Da mesma forma, a omissão de informação ao paciente por insistência do médico é mencionada por $25,2 \%$ e $26 \%$ dos grupos, respectivamente.

A transformação do modelo assistencial e a humanização do atendimento, que estão no eixo estruturante do PSF, requerem que seja garantido o direito à informação do usuário, pois é um dos elementos vitais para que este possa tomar decisões sobre as questões relacionadas a sua saúde. Os profissionais de saúde devem estar conscientes da responsabilidade de esclarecer os usuários, assim como, cabe aos gestores criar condições para o estabelecimento de uma cultura institucional de informação e comunicação que leve em conta as especificidades e peculiaridades de cada área e sua população.

Da relação de confiança, vínculo e responsabilização entre os usuários e a equipe de PSF decorre a obrigatoriedade de conversar e expor a informação de maneira compreensivel, ou seja, simples, aproximativa, inteligível, verdadeira, leal e respeitosa. Os profissionais, com base nos fundamentos advindos de seu saber técnico, buscam o que entendem ser bom para o usuário, promovendo seu bem estar e protegendo seus interesses. Porém, ao fazerem isso, não podem aniquilar a manifestação da vontade, dos desejos, dos sentimentos e das crenças de cada um (ZOBOLI e col. 2001).

Desta forma, em virtude da construção de uma relação de confiança, parece inadmissivel omitir ao usuário informações acerca de questões que lhe dizem 
respeito, como seu estado de saúde. Justificativas plausíveis para tal poderiam ser a preocupação de não lhe causar danos ou sua solicitação para não receber informações. No entanto, é preciso cautela com essas justificativas, pois não é rara na prática da atenção à saúde a utilização da autoridade profissional para favorecer ou perpetuar a dependência dos usuários em lugar promover e propiciar sua expressão autonômica e livre. Assim, é comum não os esclarecer sob alegação de que não suportariam ou, o que é pior, não compreenderiam a informação.Ainda não se pode desprezar o fato de que, muitas vezes, atrás da justificativa de que o usuário não estaria preparado para receber uma notícia, especialmente frente a diagnósticos de curso negativo, esconde-se o despreparo do próprio profissional para lidar com estas situações.

Pesquisa acerca da discussão dos cuidados médicos no fim de vida, realizada como 43 médicos e 53 usuários de serviços de atenção básica, indica que os primeiros demonstram hesitação para iniciar esse tipo de discussão, pois temem prejudicar as esperanças dos últimos e seu relacionamento com eles. Por outro lado, os resultados sugerem que os médicos provavelmente têm pouco a temer neste sentido, porque os usuários entrevistados manifestam receber bem a discussão, vêem-na como parte integrante da intimidade da relação e acreditam que os profissionais devem manejar a informação com franqueza (PFEIFER e col. 1994).

De acordo com Jonsen e col. (1999), é mais dificil aos profissionais de saúde, principalmente o médico, serem "emissários de más notícias", do que as pessoas terem capacidade para aceitar a informação. A conversa entre os profissionais e os usuários deve ser verdadeira, isto é, as declarações devem estar em consonância com os fatos da situação. Se estes são incertos, a incerteza deve ser revelada. Deve ser evitada a desilusão, ao contar o que não é verdade ou omiti-la. Com isto não se quer dizer que a forma de relatar os fatos não deve levar em conta a percepção da resistência emocional e a compreensão intelectual do usuário e/ou família. Ao contrário, a verdade pode ser "brutal", mas a maneira de dizê-la não o deve ser. A equipe de saúde precisa ser cuidadosa e sensivel ao informar, tendo em vista o respeito à autonomia e à sensibilidade das pessoas. Somente assim a capacidade do 
usuário para decidir e escolher será reforçada, além de se fomentar a relação vincular deste com os profissionais de saúde. O usuário necessita, acima de tudo, dos benefícios de um bom e confiante relacionamento com uma equipe de saúde competente e isto é mais fácil de se conseguir com honestidade do que com mentira.

Pesquisa realizada com equipes de PSF no Município de São Paulo para identificar "a visão institucional dos direitos do paciente", revela que é o profissional quem determina o que o usuário precisa saber, não se concretizando a troca de informações esclarecedoras e perdendo-se a oportunidade de um diálogo mais informativo e decisivo, isto quando o informar está presente. Outro achado que merece destaque é o fato das informações centrarem-se no tratamento, não se explicando ao usuário quais exames estão sendo solicitados ou colhidos. Afirma a autora que a população atendida é percebida como cultural e socialmente homogênea e caracterizada como "carente" ou "humilde", o que denota a suposição de dificuldade para a compreensão (BARROS 2000).

Alguns depoimentos da presente pesquisa também indicam esta percepção e caracterização dos usuários atendidos pelos entrevistados, como exemplificado a seguir:

\section{“(....) é uma população muito carente, é uma população assim, não é pobre, é miserável, miserável, falta de tudo, falta de recursos humanos, falta de dinheiro, falta de orientação (....)" (EII)}

Não se desconhece que alguns usuários podem não desejar ser informados, como revela pesquisa realizada com idosos internados em um hospital público do Município de São Paulo, na qual uma parcela, apesar de minoritária (cerca de 35\%), dos 40 entrevistados, opta pela recusa à informação e/ou prefere utilizar-se dos familiares enquanto elos da comunicação com os profissionais de saúde (OLIVEIRA e FORTES 1999). Parece, então, que se faz necessário encontrar o justo meio entre o código do silêncio e a ditadura da verdade, sendo isso possível somente através de 
uma relação de vínculo e co-responsabilização entre o usuário e a equipe de PSF, com base numa abordagem comunicativa dialógica e emancipatória.

Searight e Barbarash (1994), discutindo os aspectos clínicos, éticos e legais do consentimento livre e esclarecido na prática dos médicos de família, reconhecem que nas situações de uma relação médico-paciente prolongada é possível que alguns usuários tendam a transferir a decisão para o profissional. São usualmente competentes e comunicam uma clara preferência que deveria ser respeitada. Entretanto, para a delegação ser válida, devem ser esclarecidos que o profissional tem o dever de informá-los sobre o tratamento, que têm um direito legal de decidir sobre este, que não podem ser tratados sem seu consentimento e que têm o direito de consentir ou recusar o tratamento. Esta discussão, alertam os autores, deve ser registrada no prontuário e esta delegação deve ser realizada somente quando o usuário explicitamente declara que não quer mais ser informado ou claramente indica o desejo de que o médico tome decisão por ele. Ainda assim, os profissionais devem deixar patente que prontamente fornecerão qualquer informação adicional se o usuário mudar de idéia.

Chama atenção a preocupação dos enfermeiros de como informar para conseguir a adesão do usuário, ao invés de como transmitir a informação de maneira a assegurar decisões esclarecidas, autônomas e responsáveis que seria o esperado numa relação vincular de co-responsabilização como objetiva o PSF para os usuários e as equipes.

Neste sentido, parece oportuno observar os resultados da pesquisa desenvolvida por Christie e col. (1983) com professores do Departamento de Medicina da Família da Universidade Western Ontário, Canadá, que revela um número relativamente alto de médicos que afirmam ser sua prática usual tentar coagir usuários para aceitar investigações, tratamentos e hospitalizações. Da mesma forma, cerca de metade dos 212 enfermeiros holandeses de 150 instituições hospitalares e comunitárias afirmam "persuadir o paciente a colaborar" (VAN DER AREND e REMMERS-VAN DER HURK 1999). 
Entretanto, como afirma Brody (1983a), no uso de termos como persuadir, adular ou exortar parece estar implicado o reconhecimento do direito e da habilidade do usuário para fazer sua própria escolha e, é talvez porque se veja a possibilidade de opção pela alternativa errada que os profissionais ponham ênfase na argumentação do curso mais indicado. Assim, parece provável que os enfermeiros possam estar preocupados com a possibilidade do usuário não optar pela alternativa que consideram como a mais benéfica ou ainda que, por não compreender uma informação ou orientação da equipe, não compareça mais a USF e rompa-se o vínculo com este e sua família. Esta preocupação pode ser observada num dos discursos destacado no quadro anterior e nos que seguem:

"Sabe nesta época a paciente também estava super tranqüila, tanto que depois ela chegou com o marido; tava super tranqüila, mas foi uma coisa que foi muito trabalhada antes! Porque se naquele momento que ela veio em consulta, porque já foi dificil pra ela vir, a gente falar: 'não, o agente comunitário tem que saber, porque tem!' Provavelmente ia perder essa paciente, vai saber aonde ela ia conseguir um pré-natal, né?!" (E18)

"A gente toma cuidado para não tá ofendendo a pessoa (....)" (El1)

Eu sempre explico pro paciente de uma maneira que ele acabe não ficando muito chateado (....) com a equipe (....) porque se ficar chateado (....) vai refletir no nosso trabalho, né, então a gente tem que tentar sempre com o paciente conversar, né" (E14)

A disponibilidade de "conversar", de "trabalhar" as pendências com os usuários parece indicar que alguns profissionais reconhecem que os múltiplos contatos mantidos com este e suas famílias favorecem a troca contínua de informação e as pessoas são mais propícias a manter e compreender o que lhes é apresentado repetidamente, como afirmam Searight e Barbarash (1994). As equipes 
de saúde da família estão em uma posição singular e propicia para implementar o consentimento livre e esclarecido no espírito ético no qual foi concebido, ou seja, como uma forma para aumentar o conhecimento do usuário e a sua participação na tomada de decisão. Como têm uma relação contínua com os usuários e as famílias, podem discutir as informações pertinentes a cada situação com mais freqüência e em um contexto mais pessoal (BRODY 1989; SEARIGHT e BARBARASH 1994).

Neste sentido, vale citar que para os enfermeiros visitadores da Holanda não forçar o usuário, mas tendo claro que devem tentar chegar a um acordo imediato ou futuro, parece ser a norma mais importante quando enfrentam uma recusa da ajuda oferecida e têm objeções a esta opção (GREMMEN 1999).

A 'relação de amizade' que, algumas vezes, se estabelece entre o profissional e o usuário em decorrência das peculiaridades da atenção no PSF, como também aponta o estudo de Barros (2000), proporciona acessar informações que ultrapassam o campo do biológico e do clínico, adentrando a aspectos íntimos da dinâmica familiar. Entretanto, ao que parece, isso não é percebido positivamente pela equipe que denota certo desconforto ou constrangimento por não saber como proceder, perdendo-se um espaço de escuta e aconselhamento que poderia se desdobrar em atuação de promoção da saúde e mobilização por direitos sociais.

A questão da discussão de detalhes da situação clínica do usuário na sua frente não consistiria problema ético de importância, se fosse prática da equipe a veracidade nos processo de comunicação e o que informar e como isso seria feito, fosse apreciado e decidido no âmbito de suas reuniões. 
QUADRO 7D - PROBLEMAS ÉTICOS NAS RELAÇÕES COM OS USUÁRIOS E AS FAMÍLIAS

\begin{tabular}{|c|c|}
\hline \multicolumn{2}{|c|}{ ASPECTOS RELATIVOS À PRIVACIDADE E CONFIDENCIALIDADE } \\
\hline $\begin{array}{c}\text { Dificuldades para } \\
\text { manter a } \\
\text { privacidade nos } \\
\text { atendimentos } \\
\text { domiciliários } \\
\text { E10, E11 }\end{array}$ & $\begin{array}{l}\text { "Outra coisa (....) que pode dá também uma pré-disposição são as } \\
\text { visitas domiciliares, que às vezes você vai em tal casa de um } \\
\text { determinado paciente, ouviu certas coisas, e quando você vai na } \\
\text { visita, tem outras pessoas." (E10) }\end{array}$ \\
\hline $\begin{array}{c}\text { Dificuldades para o } \\
\text { agente comunitário } \\
\text { de saúde preservar } \\
\text { o segredo } \\
\text { profissional }\end{array}$ & $\begin{array}{l}\text { "(....) os agentes comunitários (....) são uns profissionais que não } \\
\text { podem ter esse problema porque a comunidade percebe e vai } \\
\text { pressionar e é muito grave porque (....) ele tem acesso ao prontuário } \\
\text { e ele fala do vizinho, que tem tal problema (....)” (E3) } \\
\text { "(...) e a gente sempre orienta os agentes comunitários, a equipe no } \\
\text { geral, se não sabe o que é ética, que você tem que ter respeito pelo } \\
\text { próximo. (....) Ninguém ia gostar de ser exposto!" (M7) } \\
\text { "(....) a capacitação dos agentes, um dos temas era ética e sigilo (....) } \\
\text { porque ele convivem com os pacientes lá fora, eles têm essa } \\
\text { preocupação ética muito maior que a nossa. Eles estão na casa dos } \\
\text { doentes e os doentes estão na rua deles!” (M12) }\end{array}$ \\
\hline $\begin{array}{l}\text { Compartilhamento } \\
\text { das informações } \\
\text { sobre um dos } \\
\text { membros da família } \\
\text { com demais } \\
\text { E5, E10, E11, M7, } \\
\text { M13 }\end{array}$ & $\begin{array}{l}\text { "Você acaba atendendo a familia, então, às vezes, você pode entrar } \\
\text { nessa armadilha de colocar o caso na familia, discutir o caso com a } \\
\text { familia, e o caso pertence ao paciente" (E10) } \\
\text { "Então a opinião minha era o seguinte: a mãe é responsável pela } \\
\text { menina, ela teria direito ao exame, só que o exame foi feito de uma } \\
\text { maneira escondida da mãe pela filha!" (M13) }\end{array}$ \\
\hline $\begin{array}{l}\text { Não solicitação de } \\
\text { consentimento da } \\
\text { família para relatar } \\
\text { sua história em } \\
\text { publicação científica } \\
\text { M4 }\end{array}$ & $\begin{array}{l}\text { “(....) não houve sequer conversa com a familia pra saber ... não foi } \\
\text { permitido, não houve permissão da familia para que o caso da } \\
\text { familia fosse publicado (....)” (M4) }\end{array}$ \\
\hline
\end{tabular}


A privacidade engloba a intimidade, a vida privada e a honra das pessoas, significando que são os próprios usuários que têm direito de decidir quais informações pessoais querem que sejam mantidas sob seu exclusivo controle e a quem, quando, onde e em quais condições estas informações podem ser reveladas. Isto se aplica igualmente ao âmbito interno de cada família, pois um membro pode não desejar que fatos ou dados acerca de sua saúde e vida sejam compartilhados com os demais. O mesmo se aplica às famílias em relação aos vizinhos, ainda que parentes (ZOBOLI e col. 2001).

Segundo Sacardo (2001), a privacidade constitui-se mecanismo de regulação do relacionamento entre os profissionais de saúde e os usuários, que pode facilitar o estabelecimento da confiança mútua necessária ao desenvolvimento do trabalho. Parece que isto pode assumir especial importância no PSF devido à centralidade que a relação vincular e de co-responsabilização tem na estruturação dessa estratégia de organização da atenção básica. Além do mais, o atendimento à família propicia acesso da equipe a informações mais intimas, o que chega a ser reconhecido pelos entrevistados da presente pesquisa como um problema ético.

Do direito que o usuário tem à privacidade decorre o dever de todos os integrantes da equipe manterem segredo. Como afirma Halevy (2000), sem a garantia da confidencialidade, na maioria das circunstâncias, o usuário não se sentiria à vontade para revelar à equipe de saúde informações relevantes, mas que são potencialmente embaraçosas ou mesmo não teria confiança para comparecer aos atendimentos com vistas à avaliação e tratamento.

São sigilosas não somente as informações reveladas confidencialmente, mas todas as que os trabalhadores conhecem no exercício de suas atividades, seja na anamnese clínica, na consulta de enfermagem, no exame físico, na realização de exames laboratoriais ou outras provas diagnósticas e ainda nas visitas domiciliárias. 
A percepção dos trabalhadores do PSF dos problemas relativos à preservação da confidencialidade pode ser encarada positivamente, pois recente pesquisa sobre a temática da privacidade em instituições hospitalares, realizada em hospital geral público na região metropolitana de São Paulo com usuários internados no serviço e pessoas não hospitalizadas, revela que a preocupação com a privacidade não é somente teórica, mas requerida por ambos os grupos. $O$ estudo constata a existência de diferentes expectativas em relação à privacidade, com a sua vinculação a outros conceitos, como autonomia e confidencialidade, configurando uma teia de significados articulados entre si, o que torna tênue a linha que define os limites entre um e outro (SACARDO 2001).

Alguns estudos realizados com profissionais de saúde e usuários de serviços de saúde extra-hospitalares na Austrália, Estados Unidos e Inglaterra também apontam a manutenção da confidencialidade como um problema ético freqüente para o cotidiano dos profissionais de saúde que atuam neste âmbito (ROBILLARD e col. 1989; VIENS 1994; CARMAN e BRITTEN 1995; MAYER-BRAUNACK 2001).

Dentre estas pesquisas, parece oportuno destacar os resultados do estudo qualitativo desenvolvido em diferentes cidades inglesas de uma área semi-rural, com 39 usuários de consultórios de seis médicos generalistas, com 12.000 pessoas adscritas. Em entrevistas semi-estruturadas, realizadas em suas próprias casas, os usuários eram encorajados a manifestar suas expectativas sobre a confidencialidade dos dados constantes em seus prontuários. A noção de "cuidado", como na pesquisa de Sacardo (2001), também aparece vinculada à permissão para acesso à informações de cunho privado. Os entrevistados afirmam que os profissionais da medicina e da enfermagem deveriam ter algum grau de acesso a seus registros, mas não ilimitado, sendo feitas reservas principalmente para os médicos não diretamente envolvidos no cuidado e, 23 dos participantes argumentam que nenhum membro do staff administrativo dos consultórios deveria ter acesso aos registros de seus prontuários (CARMAN e BRITTEN 1995). 
Os resultados também apontam para diferentes atitudes quanto à maneira para tratar a informação confidencial nos hospitais e nos consultórios. Dos 23 entrevistados que esperam que ninguém afora os médicos e a equipe de enfermagem, em alguns casos, tenham acesso aos registros nos consultórios, somente 3 defendem restrições similares para seus registros hospitalares. O determinante dessa diferença é o anonimato que ocorre no hospital e que não pode ser garantido nos consultórios, especialmente na realidade deles que estavam em pequenas cidades de uma área semi-rural. Também 28 dos entrevistados consideram que, comparando os registros hospitalares com os dos consultórios, os últimos incluem mais informações pessoais, como circunstâncias sociais, relacionamentos, comentários críticos e tudo abarcando um longo período de tempo (CARMAN e BRITTEN 1995).

É necessário ainda considerar, com especial atenção, o lugar da família nesta questão. Esse é marcante, como sugere o estudo de Sacardo (2001), sendo esperado que esta partilhe do segredo de um dos membros, em virtude de seu papel "cuidador", que proporciona sentimento de segurança, proteção e diminui a sensação de vulnerabilidade provocada pelo adoecimento. Os familiares são considerados como aliados no processo adoecimento/cura ou hospitalização e, dessa forma, há pouca expectativa em relação à manutenção da privacidade das informações entre a família nuclear. No entanto, fica claro que a família não deve substituir o usuário e que a questão da proximidade parece ser algo determinante, na medida em que se estabelece um limite entre os familiares mais distantes e os parentes mais próximos. Frente aos achados, recomenda a autora que o profissional de saúde deva atender às expectativas do usuário, a quem compete decidir sempre o sentido e o limite da inserção da família na sua problemática. Para tal, esse tema deverá compor parte da conversa que se estabelece entre os trabalhadores e os usuários, o que representa um desafio frente às limitações do processo de comunicação que vem sendo assinaladas.

Como lembra Brody (1983b), para os que atuam na saúde da família não pode haver discussão mais fundamental do que o significado de tratar a família como uma unidade de cuidado e conduzir os conflitos entre os interesses de um membro individualmente e dos outros integrantes da família. Nesta pesquisa, esta questão 
aparece nos problemas éticos do compartilhamento das informações sobre um dos membros da família com os demais e da solicitação de procedimentos por menores sem autorização dos pais, descrita anteriormente.

A ponderação de interesses dos diferentes membros individualmente e da familia como um todo, segundo Brody (1983b), pode constituir uma oportunidade para o fortalecimento dos laços familiares, desde que a decisão tomada resulte de uma discussão face a face entre todas as partes interessadas. Entretanto, isto não pode ocorrer como algo unilateral, imposto pela equipe de saúde, não importa quão benevolente sejam as intenções. Na presente pesquisa, o depoimento de um dos enfermeiros parece retratar essa preocupação:

“A questão da relação com a familia, entre várias pessoas da familia, você saber esta relação e não poder, não ter condição de tá fazendo uma mesa redonda, é um dilema ético." (E5)

Halevy (2000) adverte que os profissionais na atenção básica devem estar alertas para os potenciais problemas na preservação da confidencialidade, com vistas a sua prática diária. A maioria dos usuários tem família e amigos que estão interessados em seus cuidados; esposas, filhos, "primos curiosos", "vizinhos bisbilhoteiros" e vários "melhores amigos" que querem saber sobre seu estado de saúde e plano de cuidados. Uma política padrão de que o profissional não revelará informação alguma a ninguém, a não ser ao próprio usuário, embora louvável da perspectiva da confidencialidade, pode ser problemática sob outros aspectos. $\mathrm{Na}$ maior parte dos casos, dar informações gerais, omitindo detalhes delicados ou potencialmente embaraçosos parece apropriado, uma vez que não prover nada pode ser interpretado como um indicativo de que a condição do usuário é muito pior do que a realidade. A equipe de saúde da família deve lançar mão da discrição e do discernimento ao determinar o que deve ser revelado e para quem. Idealmente, devese procurar saber junto ao usuário quais são seus desejos quanto à revelação de informações suas para a família e amigos, não cedendo automaticamente à insistência de quem procura saber algo. Se o usuário for uma pessoa competente, sua 
vontade deve ser seguida e na falta da capacidade de decisão deste, seu responsável dará a orientação para os profissionais.

Ainda cabe lembrar que é comum, frente a problemas éticos, o profissional buscar conselho e orientaçâo com os colegas. Esta prática também é freqüente na vigência de dúvidas na condução do caso. Neste sentido, faz-se mister considerar que uma tênue linha separa a consulta aos colegas para uma segunda opinião da "fofoca" nos ambientes partilhados da unidade de saúde, como o refeitório ou nas reuniões técnicas (Halevy 2000).

A presença do agente comunitário de saúde, do qual não se exige uma formação especifica na área da saúde para a contratação, é motivo de especial preocupação na preservação da confidencialidade, especialmente porque este reside na área de abrangência de sua equipe. Tanto é assim que o Projeto Qualis/PSF, no Município de São Paulo, ao definir, em 1998, as atribuições do agente comunitário de saúde no programa inclui "não divulgar informações recebidas durante as visitas domiciliares a quaisquer pessoas que não pertençam à equipe de saúde". Talvez por esta razão, o próprio agente reconheça como características para trabalhar na função "ser discreto" e não "falar da vida alheia" (SILVA e DAMASO 2002).

A não solicitação de consentimento da família para relatar sua história em publicação científica, juntamente com a não solicitação de consentimento da equipe para relatar caso em publicação científica e a quebra do sigilo médico por outros membros da equipe ao publicarem relatos de casos, problemas éticos apontados e a serem listados no quadro seguinte, apesar de representarem questões não diretamente relacionados com o processo de trabalho na assistência, merecem menção pelo fato do PSF, justamente por conformar uma nova maneira de estruturar a atenção básica no SUS, estar sendo alvo de diversas pesquisas e trabalhos de acompanhamento e avaliação. O alerta fica, então, não somente para os profissionais das equipes de PSF, mas também para os pesquisadores, no sentido de que se tomem todas as medidas para assegurar a preservação da privacidade e confidencialidade dos usuários, das 
famílias e dos próprios profissionais, bem como para respeitar sua liberdade de participação nas pesquisas e seu consentimento para divulgação das histórias e casos.

Em situações de pesquisas envolvendo seres humanos, vale lembrar que esta questão é normalizada, no Brasil, pela Resolução CNS/MS 196/96 e suas complementares que, além de cuidar dos aspectos mencionados, determinam a apreciação e aprovação dos projetos por comitês de ética, previamente a sua execução. Isto deve ser rigorosamente observado pelos pesquisadores e as equipes de PSF devem exigir que este procedimento seja efetuado para, somente então decidir se participam ou não do estudo que está sendo proposto. 


\subsubsection{AS RELAÇÕES DA EQUIPE}

\section{QUADRO 8 - PROBLEMAS ÉTICOS NAS RELAÇÕES DA EQUIPE}

\begin{tabular}{|c|c|}
\hline $\begin{array}{c}\text { Falta de } \\
\text { compromisso dos } \\
\text { profissionais que } \\
\text { atuam no PSF } \\
\text { E2, E9 }\end{array}$ & $\begin{array}{l}\text { "(....) tem profissionais que não têm o compromisso de estar } \\
\text { aqui (....) faz as oito horas dele e vai embora, e simplesmente } \\
\text { não vivencia a comunidade como um todo." (E9) }\end{array}$ \\
\hline $\begin{array}{c}\text { Falta de } \\
\text { companheirismo, } \\
\text { colaboração entre } \\
\text { as equipes } \\
\mathrm{E} 2, \mathrm{E} 8, \mathrm{E} 9, \mathrm{E} 15\end{array}$ & $\begin{array}{l}\text { "(....) somos em equipes (....) e cada equipe, de certa forma, é } \\
\text { limitada a sua área (....) nós não temos aquele compromisso de } \\
\text { o dr. da área } X \text { pode dar ajuda na área } Y \text {, ou o enfermeiro da } \\
\text { área } Z \text { pode dar ajuda na área } X . " \text { (E9) }\end{array}$ \\
\hline $\begin{array}{l}\text { Desrespeito entre } \\
\text { os integrantes da } \\
\text { equipe }\end{array}$ & $\begin{array}{l}\text { "Acho que é falta de comunicação, falta de respeito pelo } \\
\text { profissional de enfermagem, mesmo! A gente trabalha } \\
\text { enquanto equipe, não que o enfermeiro é subordinado ao } \\
\text { médico, como muita gente acha! Não! Eu acho que todo mundo } \\
\text { dentro da equipe tem que ser respeitado" (E12) } \\
\text { "(...) não é dado ao profissional médico, a importância devida, } \\
\text { pra que os outros também sejam importantes, você tem que } \\
\text { diminuir sua importância, para que você não se destaque da } \\
\text { equipe. Então, a partir do momento em que isso acontece, } \\
\text { acaba a hierarquia dentro da equipe e infelizmente as pessoas } \\
\text { misturam as coisas. Elas perdem por você também até o } \\
\text { próprio respeito." (M18) }\end{array}$ \\
\hline $\begin{array}{l}\text { Despreparo dos } \\
\text { profissionais para } \\
\text { trabalhar no PSF } \\
\text { E9, E10, E19, } \\
\text { M10, M18 }\end{array}$ & $\begin{array}{l}\text { "E esta questão da capacitação (....) a gente vê muita gente que } \\
\text { chega despreparado (....)" (E9) } \\
\text { "(...) se tivesse aqui com uma capacitação que não houve, tudo } \\
\text { bem, manda entrar!" (M10) }\end{array}$ \\
\hline
\end{tabular}




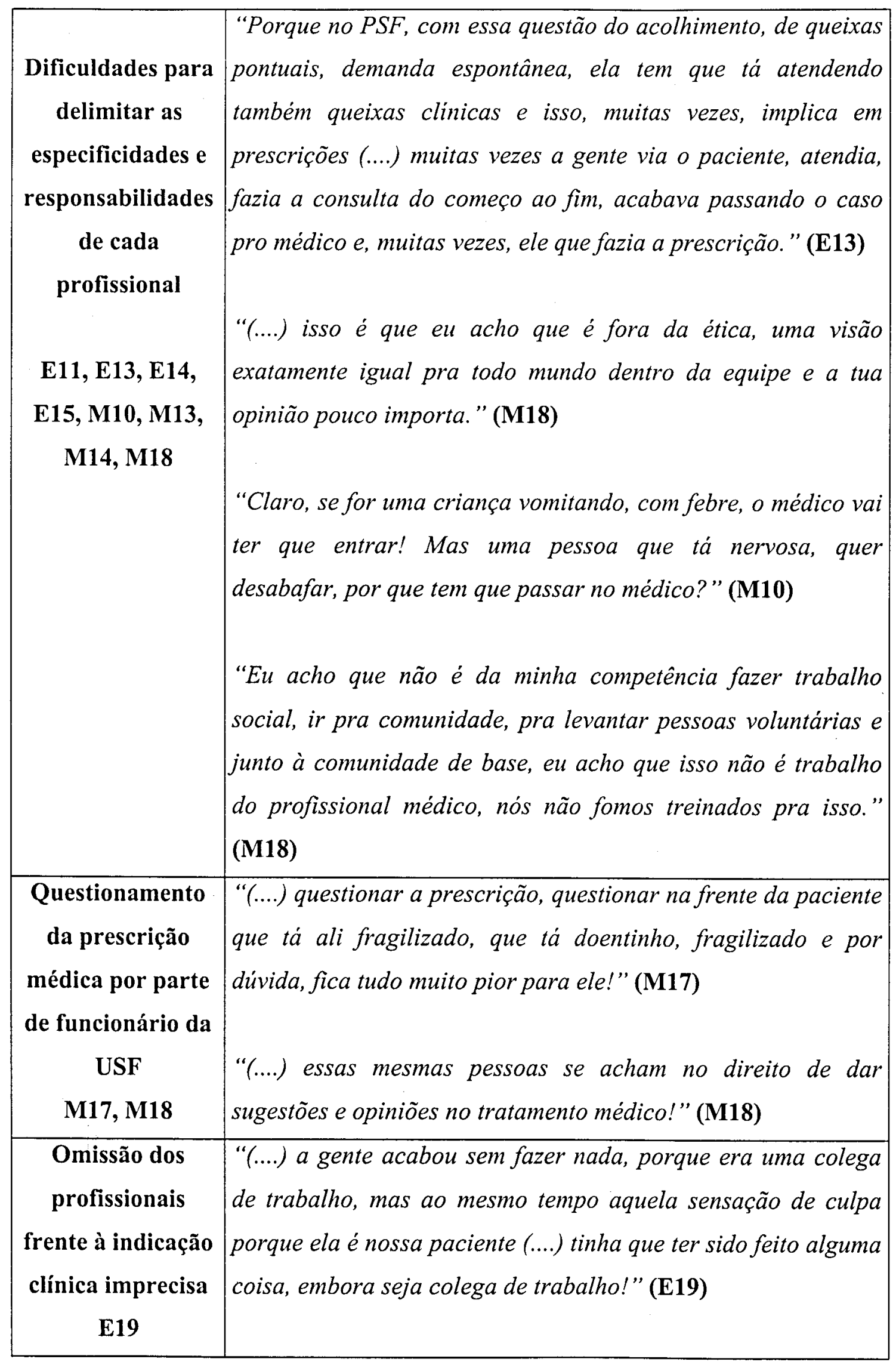




\begin{tabular}{|c|c|}
\hline $\begin{array}{c}\text { Compartilhamento } \\
\text { das informações } \\
\text { relativas ao } \\
\text { usuário e família } \\
\text { no âmbito da } \\
\text { equipe do PSF } \\
\text { E3, E5, E10, E18, } \\
\text { M7, M8, M12, } \\
\text { M14, M15 }\end{array}$ & $\begin{array}{l}\text { “(...) a partir do momento que você entra em consulta e você } \\
\text { traz as dificuldades pro profissional, você tem o direito de ficar } \\
\text { só aqui, entre } 4 \text { paredes (....)" (E18) } \\
\text { "(...) até que ponto esse sigilo da relação médico - paciente } \\
\text { (....) tá sendo quebrado a partir do momento que você abre pro } \\
\text { agente comunitário (....) não sei até que ponto a gente poderia } \\
\text { tá fazendo isso sem a permissão do paciente ou não." (M15) }\end{array}$ \\
\hline $\begin{array}{l}\text { Quebra do sigilo } \\
\text { médico por outros } \\
\text { membros da } \\
\text { equipe ao } \\
\text { publicarem } \\
\text { relatos de casos } \\
\text { M4 }\end{array}$ & $\begin{array}{l}\text { "(....) eu li esse artigo e reconheci palavras minhas do que a } \\
\text { paciente, uma das pessoas desta familia, tinha contado dentro } \\
\text { do consultório médico, então eu interpretei como meu sigilo } \\
\text { médico, meu juramento foi quebrado através de terceiros (....)" } \\
\text { (M4) }\end{array}$ \\
\hline $\begin{array}{l}\text { Não solicitação de } \\
\text { consentimento da } \\
\text { equipe para } \\
\text { relatar caso em } \\
\text { publicação } \\
\text { científica } \\
\text { M4 }\end{array}$ & $\begin{array}{l}\text { "(....) era um artigo sobre um caso da equipe que faço parte, e } \\
\text { a equipe não soube, não sabia que isso ia ser publicado (....)" } \\
\text { (M4) }\end{array}$ \\
\hline
\end{tabular}

Os problemas e conflitos nas relações entre os profissionais não são algo inesperado, especialmente se for considerado que a equipe de saúde, como afirmam Matumoto e col. (2001), configura uma rede de relações tecida no cotidiano, entre agentes que portam saberes diferenciados e desenvolvem práticas distintas, sendo necessária certa disponibilidade para que reconheçam e respeitem suas diferenças.

Neste sentido, Prescott e col. (1985) chegam a sugerir que o desacordo não é indesejável. Ao contrário, defendem que este pode ter um papel importante na 
assistência, uma vez que os enfermeiros e médicos têm perspectivas diferentes quanto a muitos problemas dos usuários.

Entretanto, para que isto seja verdade é necessário estar atento, pois os conflitos podem tanto desempenhar esse papel protetor do usuário, por levar à percepção de diferentes aspectos de seus problemas e necessidades, como pode ser prejudicial, comprometendo a qualidade da atenção à saúde. O próprio estudo de Prescott e col. (1985), realizado com mais de 1000 enfermeiros e cerca de 700 médicos de 15 hospitais gerais de seis áreas metropolitanas dos EUA, indica que a demora no cuidado do paciente e os problemas recorrentes de disputas não resolvidas são um subproduto deste desacordo entre os profissionais.

$\mathrm{Na}$ presente pesquisa, ao relatar um caso de confronto direto com um dos médicos da USF, o enfermeiro aponta como o conflito entre eles acaba por prejudicar a atenção prestada:

“(....) e isso até atrapalhou, né, no nosso trabalho, na dinâmica, porque quando você tem um entrosamento com o médico, tem muita coisa que você resolve ali, né, você é bem mais resolutiva quando você tem um entrosamento. E como a gente não se conversava, né, porque ele criou um clima de não conversar comigo mesmo, nem profissionalmente, então, eu passava tudo pra ele, tudo por escrito, então as coisas tinham que passar por mim e por ele, então era até uma mão de obra dobrada, né, porque tinha casos que se ele me falasse o que deveria fazer, ou desse a opinião de médico dele, a gente resolvia, seria muito mais resolutivo (....)" (E15)

O desacordo na equipe adquire uma nuance especial no PSF, pois neste Programa, como afirmam Silva e Damaso (2002), a identidade dos sujeitos envolvidos no trabalho fica menos clara do que nos serviços de saúde "tradicionais", o que constitui fonte de conflitos para os profissionais. Acrescente-se a isso que a conformação da equipe de PSF, além de incorporar um novo trabalhador, o agente 
comunitário de saúde, traz também uma mudança na relação numérica dos profissionais médicos e enfermeiros. Enquanto nas unidades de saúde organizadas sob a lógica programática há usualmente um enfermeiro para, pelo menos, três médicos (um clínico, um pediatra e um ginecologista que atuam, respectivamente, nos programas de saúde do adulto, da criança e da mulher) no PSF, os números se equiparam, com um médico e um enfermeiro em cada equipe.

Neste sentido, vale registrar que no PSF se imputa uma carga assistencial importante e igual ao médico e ao enfermeiro, acumulando o último as atividades de supervisão de enfermagem e dos agentes. Essa não distinção, além de refletir a reorganização da assistência em construção no PSF, pode ser fator de conflitos entre esses profissionais. Germano (1993), em seu livro acerca da ética na enfermagem brasileira, faz menção a uma pesquisa desenvolvida na década de 70 na qual, embora os médicos reconheçam o enfermeiro como alguém cientificamente preparado e capacitado, esperam desse profissional "submissão, respeito e disciplina", gerando a resistência por parte do enfermeiro que não aceita a "posição tradicionalista de auxiliar obediente de médico". É evidente que nas últimas décadas essa atitude tem sido fortemente criticada, embora, segundo a autora, seja necessário reconhecer que sua presença não é rara, devido à tradição que tem caracterizado a formação do enfermeiro e de outros profissionais de saúde.

Em pesquisa qualitativa realizada com enfermeiros de serviços de diálise, todos os entrevistados descrevem conflitos na relação com a equipe médica, com situações nas quais percebem que esta não aceita sua expertise profissional como válida ou como uma contribuição valiosa para as decisões de tratamento. Também mencionam problemas relativos aos pedidos de execução de trabalhos para os quais não têm competência legal (WELLARD 1992).

Parece oportuno destacar que os resultados do estudo de Prescott e col. (1985) mostram que, em geral, as descrições que enfatizam a competência dizem respeito aos enfermeiros e não aos médicos. Os primeiros parecem assumir a competência dos últimos, a menos que se prove o contrário. Em contraste, a preocupação dos médicos 
pela competência dos enfermeiros é básica para a discussão dos relacionamentos e desacordos, sugerindo que esta não conforma um pressuposto. O que ocorre é justamente o oposto, parece que o conhecimento e o julgamento dos enfermeiros são assumidos como suspeitos até que se demonstre o contrário pela experiência.

No presente estudo, chama atenção o depoimento de um dos enfermeiros indicando que, talvez, a percepção da competência médica adquira aspectos distintos no PSF, já que médicos de diferentes especialidades assumem o atendimento de adultos, crianças, gestantes etc. indistintamente:

"E esta questão também da capacitação, não é, a gente vê muita gente que chega despreparado ai, entendeu, muitos médicos que chega sem capacidade de assumir a população, e está aqui dentro atuando, entendeu, só que ele não passa por uma capacitação antes, ele não passa pra ver a saúde da mulher, a saúde da criança, às vezes até um ... psiquiatra ... caiu aqui de pára-quedas, e aos poucos eles ... ele vai se enquadrando ao processo, mas ... eles não são com a capacitação" (E9)

Na pesquisa de Udén e col. (1992) feita com enfermeiros e médicos do Hospital Universitário de Tromsö, Noruega, os médicos contam em suas narrativas que os enfermeiros querem participar de decisões sobre o cuidado, mas não estão preparados para assumir essa responsabilidade e dão importância a aspectos que, para eles, são irrelevantes, como a qualidade de vida. Consideram que os enfermeiros não têm vontade de se aprofundar nos problemas, por exemplo, procurando ir à biblioteca ou ler artigos.

O depoimento de alguns dos médicos entrevistados também pode ser considerado como indicativo desta análise da incapacidade dos enfermeiros para participar de decisões clínicas: 
“Ah...o sistema que a gente trabalha, né, ele dá muita liberdade a pessoas que não são médicos, darem diagnóstico, tá, e muitas vezes entra em contradição com o que você, como profissional, conclui do caso. E torna isso dificil, até pra você explicar pro paciente. Eu já vivencei, por exemplo, pessoas que não são médica, né, vou até colocar, são da área auxiliar de enfermagem, e até enfermeira mesmo, que escreveu diagnóstico e que não tinha nada a ver com o que o paciente tinha." (M18)

"Então você tem que dar muita satisfação, você tem que ficar dando explicações e você explica e as pessoas não entendem, porque ela não chega a teu nivel intelectual (....)" (M18)

"Então não é pra ser melhor que os outros, é que na realidade eu me preparei pra isso" (M18)

"Aqui, a gente no PSF tem um relacionamento diferente, nesse sentido, por exemplo, de um hospital, tem médico aqui, enfermagem, toda aquela coisa que é diferente, mas mesmo assim, de repente chegar e fazer sugestão de tratamento, ou já encaminhar paciente 'você vai fazer isso, aquilo..." Então você tem, jả com o diagnóstico que parte delas, né." (M14)

Em um estudo norte-americano, os enfermeiros apontam o desrespeito dos médicos para com eles, enfatizando a falta de confiança. Do ponto de vista destes profissionais, uma relação é boa quando o médico acredita no julgamento do enfermeiro e confia que este o chamará quando necessário. É importante para os enfermeiros sentirem-se tratados com respeito, como pessoas inteligentes e saberem que contarão com o suporte do médico na presença do paciente. Já para os médicos, tem importância a maneira como o enfermeiro os aborda e a competência clínica destes profissionais, apontando que é comum a falta de diplomacia ou tato, de bom julgamento clínico e de ajuda. Para os médicos, as características positivas incluem a 
forma do enfermeiro se comunicar com eles, sua disposição para ajudar e sua competência. Uma aproximação não exigente por parte do enfermeiro e uma não abusiva por parte do médico são comumente mencionadas (PRESCOTT e col. 1985).

Estes aspectos referentes à forma de se comunicar no contato entre os profissionais também aparecem nos depoimento de alguns dos entrevistados:

“(...) na área de auxiliar de enfermagem, né, a gente percebe que tem assim ... a falta de ética no dia a dia (....) como é que ela chega pra gente no contato (....)" M14

"em nenhum momento ele chegou para conversar comigo o caso desse paciente (....) sem te maltratar (....)" (E12)

$\mathrm{Na}$ divisão social do trabalho no campo da saúde, a enfermagem assume papel de subalternidade em relação à medicina, destacadamente, por uma questão de gênero. A posição de dependência e dominação das mulheres em relação aos homens está presente nos estereótipos de subordinação do enfermeiro ao médico (GERMANO 1993; RIZZOTTO 1999). Assim, parece que as raízes dessa situação residem, em parte, nas desigualdades de gênero construídas histórica e socialmente.

Outro dado que chama atenção no estudo de Prescott e col. (1985) é que a maioria dos médicos $(65 \%)$ e dos enfermeiros $(53 \%)$ assumem uma atitude competitiva, isto é, ambos querem fazer valer seus direitos e não se mostram cooperativos na forma de resolver seus desacordos. Este tipo de comportamento também é observado na presente pesquisa, uma vez que nas situações narradas, as pendências somente são resolvidas, quando o são, com interferência da diretoria da USF ou da coordenação do Programa. Muitas vezes, o desacordo provoca a transferência ou, até mesmo, a demissão de um dos profissionais, além de tratamentos hostis e agressivos: 
“(...) criou-se uma inimizade muito grande, né, entre eu e ele e entre ele e a equipe, né?! Criou também um problema com a direção (....)" (E15)

“(....) teve vários abaixo-assinados da população, uma parte da população queria que ele ficasse, uma parte da população queria que ele fosse embora, né, e tinha um mal estar da unidade, que também queria que ele fosse embora e terminou que ele foi transferido, ele não foi mandado embora." (E15)

Quanto às dificuldades para delimitar as especificidades e responsabilidades de cada profissional, problema que, provavelmente, subjaz aos conflitos entre enfermeiros e médicos, faz-se necessário que estes definam atribuições e responsabilidades mutuamente, discutindo as questões de qualificação e competência de maneira conjunta e não cada profissão separadamente (MAKADON e GIBBONS 1985). E isto sem esquecer que a centralidade da atenção à saúde reside no atendimento às necessidades do usuário e/ou das famílias.

Em relação à omissão dos profissionais frente à indicação clínica imprecisa, parece oportuno mencionar que outros estudos registram a denúncia de prática incompetente como um problema ético para os profissionais de saúde. Por exemplo, na pesquisa de Duncan (1992), os enfermeiros de serviços extra-hospitalares de áreas urbanas e rurais de British Columbia (Canadá) afirmam serem decisões dificeis as que envolvem o conflito entre sua relação com os colegas e seu dever de tomar uma atitude frente à prática profissional insegura ou inadequada.

Da mesma forma, enfermeiros que atuam em saúde pública, no estado de Minnesota (EUA), ao descreverem questões sobre contar a verdade como um problema ético significativo de suas práticas; exemplificam-no com situações que abrangem não denunciar a qualidade questionável da assistência prestada por alguns colegas e/ou médicos quando o bem estar do usuário está em jogo (AROSKAR 1989). 
Comparando os cenários intra e extra-hospitalar, em Israel, Wagner e Ronen (1996) mostram que delatar a incompetência de um enfermeiro ou médico ou falhar neste procedimento é um problema muito mais comum para os enfermeiros dos hospitais, embora seja importante também para os que trabalham em outros tipos de serviços, incluindo os de atenção básica.

Uma das prováveis justificativas para esse conflito pode estar na oposição entre o dever de proteger o usuário contra atos potencialmente prejudiciais e o temor de comprometer as relações da equipe. Quanto a este último aspecto, cabe lembrar que não é raro entre os profissionais de saúde, de modo especial na enfermagem, o entendimento de que por uma "questão de ética" não se deve criticar os colegas e outros membros da equipe (GERMANO 1993).

Isto pode ser denotado pelos resultados de Wellard (1992), na Austrália, que apontam as preocupações manifestas pelos enfermeiros de diálise em arranhar a confiança entre o usuário e o médico, no caso de criticarem as opiniões e as opções de tratamento, chegando mesmo a se desculparem por tecerem críticas a seus pares. Também na presente pesquisa, alguns depoimentos de enfermeiros e médicos indicam este cuidado de ambos lados:

"Então, assim, infelizmente acaba não tendo uma ética profissional, resguardar o médico, eu acabo não fazendo porque eu tenho que explicar primeiro pro agente comunitário o que aconteceu, solicitar que o paciente venha conversar comigo. Agora, com o paciente eu sempre explico de uma maneira que ele acabe não ficando muito chateado com a médica e com a equipe (....)" (E14)

"Você fica numa situação, você não quer criar atrito e, às vezes, $e$ pessoa da tua própria equipe, o que você faz? Você mente pro paciente, para salvar a barra do outro? Ou você realmente assume que aquele diagnóstico não está correto e que a pessoa pensa de 
outra forma e você tenta contornar e nem sempre consegue isto." (M18)

Esta questão pode ser agravada pelo despreparo dos profissionais para trabalhar no PSF, outro dos problemas éticos apontados nas relações da equipe. Quanto a isto, vale registrar que um estudo realizado com enfermeiros distritais e visitadores, na Inglaterra, revela preocupações de ambos grupos em relação à falta de treinamento para se envolverem nas atividades de promoção à saúde, uma vez que constituiam, no momento das entrevistas, uma prática nova para muitos deles (THOMAS e WAINWRIGHT 1996).

Compartilhar informações no âmbito da equipe é fundamental para um trabalho de qualidade na atenção às famílias. Entretanto, será que todos os trabalhadores têm que ter acesso a tudo? A conduta mais prudencial parece ser a preconizada por Fortes (1998) que pondera o fato do trabalho multiprofissional não significar que todos os membros da equipe necessitem e devam ter acesso a todas as informações de um usuário. Desta maneira, a despeito da troca de informações entre a equipe ser necessária, esta deve ser limitada às informações que cada profissional precisa para realizar suas atividades em benefício do usuário e/ou família. Neste sentido, é pertinente lembrar que esta limitação relacionada à prestação de cuidado é percebida e requerida pelos usuários, como já foi discutido anteriormente.

A equipe de saúde da família incorpora, como já foi discutido, o agente comunitário de saúde, que possui posição singular por obrigatoriamente residir na área de adscrição na qual atua. Este trabalhador traz ao conhecimento da equipe informações sobre a vida cotidiana das familias, suas casas e, até mesmo, fatos anteriores à composição da equipe na região, atuando como um "prolongador dos olhos e da apreensão da equipe". Esses dados são incorporados pelos enfermeiros e médicos como instrumentos de gerenciamento e para nortear o tipo de atendimento necessário (SILVA e DAMASO 2002). Nas atividades do agente comunitário de saúde parece ser crucial identificar as informações relevantes para a geração de beneficios à comunidade e para o acionamento e orientação do trabalho da equipe, 
sendo esse o critério para discernir quais informações de domínio do agente que devem ser compartilhadas com o restante da equipe, e vice-versa.

\subsubsection{AS RELAÇÕES COM A ORGANIZAÇÃO E O SISTEMA DE SAÚDE}

Na categoria "problemas éticos nas relações com a organização e o sistema de saúde" é possivel, a partir de elementos em comum, agregar os achados em subgrupos menores, que são apresentados nos quadros que seguem. Os quadros, com os diferentes sub grupos, recebem uma única numeração e título a fim de deixar claro que dizem respeito à mesma categoria.

Os problemas apontados pelos enfermeiros e médicos nesta categoria guardam uma relação direta com a ética na gestão dos serviços de saúde. Isto não é de todo surpreendente, já que pela própria finalidade das instituições sanitárias é muito dificil separar a ética dos cuidados de saúde da ética na administração em saúde (ZOBOLI 2002).

Parece claro que a conformação do sistema e das organizações de saúde pode se apresentar como um fator gerador de problemas éticos, acabando também por determinar a forma de sua percepção, análise e solução. Jonsen e col. (1999) alertam que o "contexto da prestação dos cuidados tem vindo a assumir uma proeminência nunca antes atingida" e que "ocasionalmente, os aspectos contextuais parecerão mais importantes e, nalgumas vezes serão decisivos" (p. 154).

Ao se considerar que, apesar de definido legalmente desde a Constituição de 1988, o SUS ainda encontra-se em fase de consolidação de sua implantação e, mais especificamente, em São Paulo dá seus primeiros passos após anos de desmonte da rede pública de saúde e se for acrescentado a isto que o PSF é uma estratégia nova para a reorganização da atenção básica, não deve causar estranheza o fato de boa parte dos problemas éticos vividos pelos enfermeiros e médicos serem decorrentes de aspectos organizacionais, tanto no âmbito da própria USF como do sistema e da rede de saúde. 
QUADRO 9A - PROBLEMAS ÉTICOS NAS RELAÇÕES COM A ORGANIZAÇÃO E O SISTEMA DE SAÚDE

\begin{tabular}{|c|c|}
\hline \multicolumn{2}{|r|}{ ASPECTOS RELATIVOS A USF } \\
\hline $\begin{array}{c}\text { Dificuldades para } \\
\text { preservar } \\
\text { privacidade por } \\
\text { problemas na } \\
\text { estrutura física e } \\
\text { rotinas da USF } \\
\text { E1, E10, M8 }\end{array}$ & $\begin{array}{l}\text { "a gente ouve na própria sala de recepção (....) se trata de questões } \\
\text { intimas, prá tá falando em público, ou pra tentar conseguir uma vaga } \\
\text { como médico.". (E1) } \\
\text { "Esse prontuário fica na recepção, mas a maioria das pessoas que } \\
\text { trabalha aqui tem acesso a ele!" (M8) }\end{array}$ \\
\hline $\begin{array}{l}\text { Falta de estrutura } \\
\text { na USF para a } \\
\text { realização das } \\
\text { visitas domiciliárias } \\
\text { M18 }\end{array}$ & $\begin{array}{l}\text { "É impossivel você ver todos os pacientes. A pé? Tem dia que chove, } \\
\text { tem dia que faz calor demais. (....) tem que remanejar paciente de } \\
\text { agenda pro dia que tem VD porque não deu para você atender } \\
\text { aquele dia. Então você acaba deixando os acamados pra lá." (M18) }\end{array}$ \\
\hline $\begin{array}{l}\text { Falta de condições } \\
\text { na USF para } \\
\text { atendimentos de } \\
\text { urgência } \\
\text { M18 }\end{array}$ & $\begin{array}{l}\text { "Outra coisa que eu acho que vai de encontro com a ética é vocé } \\
\text { fazer atendimento de urgência num serviço que não tem estrutura pra } \\
\text { isso" (M18) }\end{array}$ \\
\hline $\begin{array}{c}\text { Falta de apoio } \\
\text { estrutural para } \\
\text { discutir e resolver } \\
\text { questões que } \\
\text { suscitam problemas } \\
\text { éticos e/ou legais } \\
\text { E5, E11, E13, E18, } \\
\text { E19 }\end{array}$ & $\begin{array}{l}\text { “(...) em equipe, resolvemos, por nós mesmos, porque nós não temos } \\
\text { uma parte ética, legal (....)" (E18) }\end{array}$ \\
\hline $\begin{array}{l}\text { Falta de } \\
\text { transparência da } \\
\text { direção da USF no } \\
\text { trato dos problemas } \\
\text { com os profissionais } \\
\text { E17 }\end{array}$ & $\begin{array}{l}\text { "(...) porque (....) essa ética, às vezes, vai um pouco por água } \\
\text { abaixo, por (....) misturar o lado pessoal com o lado profissional, às } \\
\text { vezes, as pessoas não sabem separar não!" (E17) }\end{array}$ \\
\hline
\end{tabular}


As exigências para o respeito à privacidade e manutenção da confidencialidade não se restringem à atitude dos trabalhadores que têm acesso a fatos e informações da intimidade dos usuários e das famílias, mas se estendem ao projeto arquitetônico, às relações diárias e aos procedimentos e rotinas da unidade e da equipe. Na organização interna da rotina e dos fluxos da USF, deve-se buscar ativamente a preservação da confidencialidade das informações e a garantia da privacidade fisica e moral dos usuários e suas famílias, criando condições estruturais para que isto ocorra e evitando-se o que pode causar situações de exposição desnecessária, pois, como bem revelam os depoimentos dos enfermeiros e médicos, muitas vezes, inadvertidamente em nome de facilitar o trabalho, pode-se expor a privacidade das pessoas.

$\mathrm{Na}$ falta de uma estrutura formal que sirva de apoio para a discussão e a resolução dos problemas éticos que os enfermeiros e médicos enfrentam no PSF, resta-lhes lançar mão dos conselhos dos colegas para orientá-los nestas questões:

“(...) até hoje eu converso com muita gente né, para ouvir uma opinião, né, mas ainda eu tô meio dividido, eu não sei se eu fiz certo, se eu fiz errado, se acontecer de novo o que que eu vou fazer? Então não sei!" (M10)

Na pesquisa de Wagner e Ronen (1996), em Israel, quando questionados em que extensão os esforços para lidar com problemas éticos são institucionalizados, mais da metade dos enfermeiros, tanto nos hospitais como nos outros tipos de serviços de saúde, relata que podem discutir as questões éticas em reuniões multidisciplinares e treinamentos, estando os outros fóruns, como as comissões, menos disponiveis.

Parece oportuno destacar, segundo afirmam Oberle e Hughes (2001), a necessidade dos administradores de saúde reconhecerem o fardo carregado pelos enfermeiros e médicos como parte de sua prática diária. Considerando que as decisões éticas são moduladas pelas condições do local de trabalho, as autoras 
recomendam que sejam implementadas estratégias para apoiar o processo de tomada de decisão e também sejam criadas oportunidades para os profissionais de saúde envolvidos na assistência se engajarem em discussões de temas éticos, devendo isto ser foco central para os administradores que desejam fomentar um ambiente de trabalho sadio e colaborativo.

Em relação à falta de transparência da direção da USF no trato dos problemas com os profissionais, vale dizer que um dos maiores desafios éticos que se apresenta aos que estão em função de gerência é pautar o enfrentamento dos conflitos pela essência das questões e não pela personalidade dos envolvidos ou pelos interesses pessoais afetados, tornando translúcido aos integrantes da organização que a resolução de situações conflitivas considera o mérito, não sendo aceitos ataques ou privilégios pessoais ou, ainda, práticas não raras, como o uso de influências, o favoritismo e a camuflagem de fatos por covardia, temor, adulação ou servilismo. Neste sentido, faz-se mister assinalar que o poder da e na organização requer os limites da justiça e dos direitos, a fim de não causar danos ou abusar da situação (ZOBOLI 2002).

O poder na organização, quando guiado pela justiça e direitos, busca possibilidades de agir de forma eticamente correta, propiciando momentos e espaços para a reflexão ética, os quais, por sua vez, dependem das situações de comunicação nela existentes. Para que a organização realize suas possibilidades de reflexão ética, faz-se necessário desenvolver suas capacidades de comunicação, pois somente assim se potencializa a capacidade dos trabalhadores para ponderar cursos de ação alternativos e justificar a eleição feita com razões válidas e, em última instância, é esta capacidade de render contas que configura a responsabilidade. Equipes que se comunicam primordialmente por memorandos, informes, formulários ou em reuniões repletas de rituais e sinais, nas quais as discussões diretas, francas e abertas em torno de questões difíceis são raras e obstaculizadas terão mais dificuldade de lidar com os problemas éticos do cotidiano (ZOBOLI 2002). 
Um dos objetivos do PSF é contribuir para reorientação do modelo assistencial a partir da atenção básica, que não inclui procedimentos de atendimento à urgência e emergência. Entretanto, muitas vezes, a USF é o único recurso de saúde disponivel para a população. Parece, então, que da mesma forma que a equipe deve delimitar suas especificidades, a rede também necessita discutir os limites e resolubilidade esperada de cada serviço, sem esquecer que são estes que devem se adaptar e atender às necessidades de saúde locais e não ao contrário. 


\section{QUADRO 9B - PROBLEMAS ÉTICOS NAS RELAÇÕES COM A ORGANIZAÇÃO E O SISTEMA DE SAÚDE}

\begin{tabular}{|c|c|}
\hline \multicolumn{2}{|c|}{ ASPECTOS RELATIVOS A REDE DE SERVIÇOS DE SAÚDE } \\
\hline $\begin{array}{c}\text { Excesso de } \\
\text { famílias adscritas } \\
\text { para cada equipe }\end{array}$ & $\begin{array}{l}\text { “(....) a gente tem } 250 \text { familias por agente comunitário, eu } \\
\text { tenho } 5 \text { agentes comunitários, então eu teria } 1250 \text { familias na } \\
\text { nossa responsabilidade. Por mais que a gente tente, a gente } \\
\text { não consegue dar conta da demanda (....)” (E14) } \\
\text { “(...) um aumento ai de cerca de } 50 \% \text { no número de famílias e } \\
\text { conseqüentemente (....) de } 50 \% \text { da demanda (....) na premência } \\
\text { de atender essa demanda (....) implica em possibilidade de } \\
\text { determinadas ações que do ponto de vista ético não são } \\
\text { consideradas adequadas (....) você passa a prescrever por } \\
\text { tempo maior (....) às vezes você tem que prescrever sem ter } \\
\text { visto o paciente (....)”. (M9) }\end{array}$ \\
\hline $\begin{array}{l}\text { Restrição do } \\
\text { acesso dos } \\
\text { usuários aos } \\
\text { serviços } \\
\text { E14, E15 }\end{array}$ & $\begin{array}{l}\text { “(...) teve uma restrição a consulta médica porque a agenda } \\
\text { dele começou a se esgotar por muito, muito tempo, então você } \\
\text { acabava selecionando os pacientes pra passar" (E15) }\end{array}$ \\
\hline $\begin{array}{c}\text { Demérito dos } \\
\text { encaminhamentos } \\
\text { feitos pelos } \\
\text { médicos do PSF } \\
\text { E3, M5, M16 }\end{array}$ & $\begin{array}{l}\text { “(...) o mais chocante (....) foi o médico nem querer (....) } \\
\text { receber a gestante por ter sido atendida por um clinico (....) e } \\
\text { já questionar para a paciente porque ela é atendida por um } \\
\text { clinico e não por um ginecologista." (E3) } \\
\text { "Eu não sei se a visão do pessoal de área hospitalar, que em } \\
\text { posto de saúde a gente só trata de mulher grávida e verminose, } \\
\text { não sei se eles têm essa visão ainda, e não valoriza o } \\
\text { funcionário que trabalha em posto de saúde (....)" (M16) }\end{array}$ \\
\hline
\end{tabular}




\begin{tabular}{|c|c|}
\hline $\begin{array}{l}\text { Dificuldades no } \\
\text { acesso a exames } \\
\text { complementares }\end{array}$ & $\begin{array}{l}\text { “(...) cota de coleta (....) não tem como, a gente não dá cota } \\
\text { por doença, a gente não vai pedir pro paciente: 'adoece agora } \\
\text { de diabetes, porque já estourou a cota de hipertensos"." (E14) }\end{array}$ \\
\hline E14, M9, M16 & $\begin{array}{l}\text { "Em todo o lugar que ele vai, ele bate e volta: não faz! Não } \\
\text { faz! Não faz!" (M9) }\end{array}$ \\
\hline $\begin{array}{c}\text { Dificuldades } \\
\text { quanto ao retorno } \\
\text { e confiabilidade } \\
\text { dos resultados de } \\
\text { exames } \\
\text { laboratoriais } \\
\text { E5, E7, E14 }\end{array}$ & $\begin{array}{l}\text { “(...) você está lidando com a vida das pessoas, então você } \\
\text { precisa, se você tem uma referência, você tem um apoio } \\
\text { diagnóstico, você precisa confiar no seu diagnóstico." (E5) }\end{array}$ \\
\hline $\begin{array}{l}\text { Falta de } \\
\text { retaguarda de } \\
\text { serviço de remoção }\end{array}$ & $\begin{array}{l}\text { "(....) o mais gritante de todos não só exclusivamente pro PSF, } \\
\text { como os demais postos pra rede pública, é a falta de } \\
\text { retaguarda (....) isso é o dia a dia (....) não tem ambulância } \\
\text { disponivel (...) O que você faz? Você fica numa situação } \\
\text { horrivel!" (M16) } \\
\text { "Eu já fiquei uma manhã inteira e não consegui ambulância. A } \\
\text { diretora do posto pôs o paciente no carro dela e levou. Mas o } \\
\text { resgate se recusou, porque aqui é uma instituição e quem abre } \\
\text { instituição como essa tem que ter ambulância! Foi o que falou } \\
\text { o médico chefe do resgate!" (M18) }\end{array}$ \\
\hline
\end{tabular}

Sem esquecer as diferenças entre os diversos sistemas de saúde, bem como as políticas públicas em cada país, vale citar que as questões de referência e acesso a serviços e procedimentos complementares também aparecem como problemas éticos para os profissionais de saúde em estudos feitos nos Estados Unidos e Canadá (ROBILLARD e col. 1989; OBERLE e HUGHES 2001). No estudo canadense, feito com enfermeiros e médicos de um hospital geral, a disponibilidade de recursos emerge como uma preocupação nos dois grupos de profissionais, apesar das 
diferenças. Para os últimos, ter a responsabilidade de ser o guardião do portão (gatekeeper) e de precisar alocar os recursos, decidindo sobre a solicitação ou não de procedimentos causa considerável angústia. Já as preocupações dos enfermeiros estão mais voltadas à sua incapacidade de prover um cuidado de boa qualidade devido aos cortes financeiros e de pessoal (OBERLE e HUGHES 2001).

Levantamento de diversos estudos acerca da temática da referência e contrareferência no sistema de saúde brasileiro, feito por Maeda (2002), mostra que há dificuldades estruturais e processuais dos serviços para manejar essa questão nas situações práticas da assistência à saúde, dependendo esses mecanismos, muitas vezes, do conhecimento e do relacionamento dos profissionais, sem garantia de acesso dos usuários aos serviços necessários através de uma regulação do próprio sistema com instrumentos formalizados.

Os depoimentos abaixo expressam esta realidade da falta de um sistema formalizado e institucionalizado para referência e contra-referência na prática cotidiana dos entrevistados:

"Outra coisa que atrapalha também (....) é a falta de comunicação entre as unidades de saúde e as unidades hospitalares, é uma deficiência de comunicação, mas é uma comunicação burocrática que está deficiente, coisas banais, por exemplo: encaminhamentos, via de encaminhamento, exames que são pra ser feito no hospital e mandam para a unidade de saúde e os mais diversos motivos: ou porque falta tudo, ou porque resolveram não fazer mais, ou porque a funcionária é mal orientada, manda o paciente de volta, então, a gente tem muito problema com isso, muita dor de cabeça com isso $(\ldots .) ".(M 16)$

“(...) então hoje esse ecocardiograma está quase impossivel de ser feito! Em todo o lugar que ele vai, ele bate e volta: não faz! Não faz! 
Não faz! Não faz pra quem é SUS, para nós que pedimos, né?! Isso não é um ... não é pessoal a mim, é pessoal ao sistema. " (M9)

O PSF no Município de São Paulo depara com insuficiências no funcionamento da retaguarda especializada e nos mecanismos de referência e contrareferência desde a primeira fase de implantação do Projeto Qualis. Parece que essa dificuldade persiste, sendo que em estudo recente quase todos médicos, enfermeiros, auxiliares de enfermagem e gerentes locais entrevistados identificam problemas com o fornecimento de medicação e acesso a serviços de referência e contra-referência, tanto ambulatoriais como leitos para internação. Acrescentam a essas dificuldades para a execução do trabalho, a sobrecarga pelo número excessivo de famílias e a abordagem de situações de miséria e exclusão social, como violência, desemprego etc. (SILVA e DAMASO 2002).

\subsection{RESULTADOS E DISCUSSÃO: MOMENTO II}

Para o momento II, são incluídas 33 entrevistas, 18 dos enfermeiros e 15 dos médicos. Do último grupo profissional, foi excluído um entrevistado (médico 5) que não permitiu a gravação do depoimento. A cinco enfermeiros entrevistados foi apresentado apenas o cenário fixo 'Perturbando a Rotina'. Aos outros treze foram propostos dois casos, sendo que 6 discutiram o 'Preservando a Confidencialidade' e 7 o 'Atendendo Adolescentes'. Dentre os médicos, a dois foi proposto apenas o caso fixo; um deles (médico 16), por questões de tempo disponível para a entrevista, analisou apenas o 'Preservando a Confidencialidade' e os demais responderam aos dois casos, então, além do fixo, os 14 médicos restantes dividiram-se igualmente pelos cenários 'Preservando a Confidencialidade' e 'Atendendo Adolescentes'. Em resumo, para o cenário hipotético 'Perturbando a Rotina' foram analisados 32 discursos (18 enfermeiros e 14 médicos); para o 'Preservando a Confidencialidade' 13 (6 enfermeiros e 7 médicos) e para o 'Atendendo Adolescentes' 14 (7 em cada grupo), o que totaliza 59 depoimentos. 
A distribuição dos enfermeiros e médicos, no que tange à formulação do problema ético presente nos cenários, segundo os enfoques principialista, das virtudes, dos cuidados e da ética profissional, encontra-se no quadro adiante. No caso 'Perturbando a Rotina', que traz um problema ético cercado de maior sutileza, mas muito comum e próprio da atenção à saúde nas USF, pode-se observar nos enfermeiros uma concentração no enfoque dos cuidados, seguida do principialismo e das virtudes. Nos médicos, os enfoques do cuidado e do principialismo aparecem de maneira equilibrada, seguidos da virtude. Esta situação muda conforme os cenários analisados, assim, no 'Preservando a Confidencialidade' e 'Atendendo Adolescentes' os enfermeiros distribuem-se entre os enfoques principialista e do cuidado, enquanto que os médicos concentram-se no principialista, com um deles recorrendo ao das virtudes no primeiro caso e um ao do cuidado no segundo. Estas duas situações, bastante discutidas em aulas e reuniões de atualização, trazem casos de menor ambigüidade, nos quais as questões do respeito à autonomia, privacidade, confidencialidade e verdade aparecem de maneira explicita, o que poderia levar os profissionais a formularem os problemas expostos como pendências de direitos. Nos casos mais ambíguos ou sutis, a exemplo do 'Perturbando a Rotina', o enfoque do cuidado mostra-se uma alternativa bastante presente, talvez até pela própria questão do vinculo entre a equipe e os usuários incentivado pelo PSF e a prioridade que o Programa confere ao acompanhamento do diabético e hipertenso, sendo este justamente um dos motivos para a seleção de tal cenário para o presente estudo. 


\section{QUADRO 10: FORMULAÇÃO DOS PROBLEMAS ÉTICOS SEGUNDO OS ENFOQUES E CENÁRIOS HIPOTÉTICOS}

\begin{tabular}{|c|c|c|c|}
\hline $\begin{array}{ll} & \text { CASO } \\
\text { ENFOQUE } & \end{array}$ & $\begin{array}{c}\text { PERTURBANDO } \\
\text { A ROTINA }\end{array}$ & $\begin{array}{c}\text { PRESERVANDO A } \\
\text { CONFIDENCIALIDADE }\end{array}$ & $\begin{array}{c}\text { ATENDENDO } \\
\text { ADOLESCENTES }\end{array}$ \\
\hline PRINCIPIALISTA & $\begin{array}{c}\text { E2, E12, E13, E14, } \\
\text { E15, E17 } \\
\text { M4, M6, M10, M14, } \\
\text { M17, M18 }\end{array}$ & $\begin{array}{c}\text { E6, E7, E13, E14 } \\
\text { M6, M8, M12, M13, M15, } \\
\text { M16 }\end{array}$ & $\begin{array}{c}\text { E12, E15, E17 } \\
\text { M7, M9, M10, M17, } \\
\text { M18, M14 }\end{array}$ \\
\hline DAS VIRTUDES & $\begin{array}{c}\text { E9, E11, E18 } \\
\text { M2, M7, M8, M9 }\end{array}$ & M11 & $-\cdots--$ \\
\hline DO CUIDADO & $\begin{array}{c}\text { E1, E3, E5, E6, E7, } \\
\text { E8, E10, E16, E19 } \\
\text { M1, M11, M12, } \\
\text { M13, M15 }\end{array}$ & $\mathrm{E} 8, \mathrm{E} 10$ & $\begin{array}{c}\text { E9, E16, E18, E19 } \\
\text { M4 }\end{array}$ \\
\hline $\begin{array}{l}\text { DA ÉTICA } \\
\text { PROFISSIONAL }\end{array}$ & -.-- & -.-- & E11 \\
\hline
\end{tabular}

Pode-se observar que para treze profissionais ( 8 enfermeiros e 5 médicos) há uma coincidência de enfoques na elaboração dos dois problemas apresentados. Assim, os enfermeiros 12,13,14, 15 e 17 e os médicos $6,10,14,17$ e 18 lançam mão do enfoque principialista e os enfermeiros 8,10 e 19 recorrem ao do cuidado, em ambos casos equacionados.

Tomando os enfoques sem distingui-los pelos cenários, tem-se que 13 depoimentos dos enfermeiros e 18 dos médicos formulam o problema de maneira mais próxima ao enfoque principialista; no enfoque das virtudes registram-se 3 depoimentos dos enfermeiros e 4 dos médicos; no do cuidado aparecem 15 depoimentos de enfermeiros e 6 dos médicos e apenas um de enfermeiro na ética profissional. 
Chama a atenção que haja menos enfermeiros que médicos no enfoque das virtudes, uma vez que o modelo da "enfermeira virtuosa" é uns dos que marca a construção histórico-social da ética desta prática profissional. Isto talvez possa ser motivado pelo fato dos enfermeiros virem, nos últimos tempos, desenvolvendo um processo de avaliação de sua independência como profissionais e de revisão coletiva e crítica da natureza de seus papéis profissionais, atividades e responsabilidades, como explicam Rickard e col. (1996). Segundo os autores, neste processo, a associação entre enfermagem e cuidado tem ganhado ímpeto e, em conseqüência, os enfermeiros estão conscientemente abraçando uma ética do cuidado como uma reflexão do que é distintivo sobre a sua profissão. A despeito das diferenças dos contextos onde são realizados os estudos, parece que esta justificativa também poderia ser aplicada à presente pesquisa para explicar a diferença entre os dois grupos na formulação pelo enfoque dos cuidados.

De acordo com Rickard e col. (1996), os estereótipos profissionais e a cultura que cercam a prática da atenção à saúde podem influenciar o modo dos profissionais pensarem acerca dos problemas éticos, o que sustentaria determinadas diferenças no equacionamento ético dos enfermeiros e dos médicos, com os primeiros mais inclinados à abordagem do cuidado e os últimos mais voltados ao enfoque da justiça $^{18}$. A relação entre enfermagem e cuidado deve-se tanto ao fato destes profissionais estarem adotando esta conexão como um elemento chave do desenvolvimento de sua identidade profissional, quanto à influência dos estereótipos profissionais que atribuem aos médicos a tarefa de curar e aos enfermeiros a de cuidar. Este entendimento, por sua vez, decorre da história das duas práticas profissionais marcada, profundamente, pelas relações de gênero, com a associação da enfermagem ao feminino e da medicina ao masculino. Os estereótipos e atitudes ligados aos gêneros não constituem algo externo, imposto às profissões de enfermagem e médica de fora, mas são internalizados pelos próprios profissionais

Cabe ainda apontar que, embora tenha sido predominantemente nos sujeitos mulheres que Carol Gillingan encontrou a voz que pendia para a orientação do

\footnotetext{
${ }^{18}$ Como definido por Gilligan (1998).
} 
cuidado, a autora sustenta que as tendências para as perspectivas morais do cuidado e da justiça não são exclusivamente baseadas no gênero, mas influenciadas pela experiência, incluindo a educação e ocupação. Assim, parece plausivel que o equacionamento ético voltado para o cuidado esteja historicamente mais ligado aos enfermeiros, enquanto o da justiça aos médicos (RICKARD e col. 1996).

Por esta razão e entendendo que estes contrastes podem ser melhor expressos em termos da distinção entre parcialidade e imparcialidade no equacionamento moral, Rickard e col. (1996) conduzem pesquisa quantitativa a fim de explorar a distribuição parcial e imparcial do equacionamento ético em uma amostra de enfermeiros e médicos de diferentes serviços de saúde australianos. A finalidade principal do estudo é descobrir se o gênero ou a ocupação influenciam a abordagem parcial ou imparcial que os participantes formulam para os diversos cenários hipotéticos com dilemas éticos que the são apresentados. Para os autores, a parcialidade caracteriza um aspecto central da orientação do cuidado e envolve os juizos que enfatizam as conexões pessoais e favorecem terceiros, com os quais se é pessoalmente conectado, sobretudo nas situações em que os interesses destes competem com os de outros aos quais não se é pessoalmente ligado. Por outro lado, o equacionamento imparcial baseia-se em juízos neutros e desconectados que não privilegiam ligações pessoais e refletem uma preocupação pelas exigências decorrentes da igualdade e responsabilidade impessoal, expressas em termos dos direitos universais, regras e princípios (RICKARD e col. 1996; KUSHE e col. 1997; KUSHE e col. 1998).

Em muitos aspectos, para os autores, os resultados de seu estudo surpreendem e não correspondem à expectativa de que os enfermeiros raciocinariam mais parcialmente e os médicos mais imparcialmente. As medidas tomadas evidenciam que não há associação entre o tipo de equacionamento e a ocupação ou gênero dos respondentes, ou seja, os enfermeiros e médicos entrevistados são igualmente propensos para responder parcial ou imparcialmente aos problemas éticos propostos nas questões. Concluem, assim, que os achados não sustentam a concepção de que a ética parcial do cuidado seja característica do enfermeiro e a imparcial da justiça, 
própria do médico. Enfermeiros e médicos pensam de ambos modos, em diferentes ocasiões (RICKARD e col. 1996; KUSHE e col. 1997; KUSHE e col. 1998).

Pesquisa etnográfica desenvolvida por Robertson (1996) em uma enfermaria psiquiátrica, na Inglaterra, com o objetivo de estudar empiricamente a teoria moral dos princípios, das virtudes ou as feministas - que descreveria de forma mais adequada as abordagens dos enfermeiros e médicos no cuidado diário ao paciente chega a resultados distintos, apontando diferenças entre o equacionamento moral dos dois grupos profissionais. As observações mostram uma coincidência entre a virtude e as concepções de beneficência baseadas no relacionamento (um conceito elaborado na teoria feminista do relacionamento) e, embora o compromisso com a beneficência fosse central para toda a equipe, a ocorrência deste tipo de equacionamento encontrase mais expresso entre os enfermeiros (16 eventos) do que entre os médicos (3 eventos).

De maneira geral, no presente estudo, a despeito das diferenças denotadas no quadro anterior, é possível depreender da leitura dos depoimentos que os profissionais, tanto médicos quanto enfermeiros, têm preocupação em preservar os direitos individuais, mas buscam fazê-lo de forma a proteger ao máximo tanto os vínculos familiares quanto os da equipe com os usuários, o que poderia ser considerado como uma mescla dos enfoques principialista e do cuidado. Isto ficará mais claro ao se analisarem os quadros que resumem as recomendações feitas e cruzam os distintos enfoques presentes nos argumentos dos discursos. Porém, antes de se partir para este ponto, parece necessário destacar alguns trechos de depoimentos que se prestam a exemplificar as formulações apresentadas e elementos dos enfoques que aparecem no equacionamento ético que redunda nas recomendações. No quadro a seguir, exemplifica-se, de maneira sucinta, as formulações apresentadas aos problemas éticos de cada cenário, segundo os enfoques principialista, das virtudes, do cuidado e da ética profissional. 


\section{QUADRO 11: FORMULAÇÃO DOS PROBLEMAS ÉTICOS SEGUNDO OS} ENFOQUES

\begin{tabular}{|c|c|}
\hline \multicolumn{2}{|r|}{ PERTURBANDO A ROTINA } \\
\hline $\begin{array}{r}\text { ENFOQUE } \\
\text { PRINCIPIALISTA }\end{array}$ & $\begin{array}{l}\text { "(...) o problema de saúde dele é meu sim, mas a decisão de tratar é } \\
\text { dele" (E15) }\end{array}$ \\
\hline $\begin{array}{l}\text { ENFOQUE DAS } \\
\text { VIRTUDES }\end{array}$ & $\begin{array}{l}\text { "(...) na nossa profissão todo paciente ele tem que valer a pena } \\
\text { sempre. Por que? Porque senão a coisa perde o sentido, né. Eu acho } \\
\text { que o trabalho da gente perde o sentido (....)" (E11) }\end{array}$ \\
\hline $\begin{array}{l}\text { ENFOQUE DO } \\
\text { CUIDADO }\end{array}$ & "o vínculo não deixa a gente desistir" (E19) \\
\hline \multicolumn{2}{|r|}{ PRESERVANDO A CONFIDENCIALIDADE } \\
\hline $\begin{array}{r}\text { ENFOQUE } \\
\text { PRINCIPIALISTA }\end{array}$ & $\begin{array}{c}\text { "É direito dele sigilo médico, mas é direito também da mulher ter a } \\
\text { saúde tratada, então nada mais justo que ele então conte já que ele } \\
\text { quer tanto proteger ela, né?!" (E14) }\end{array}$ \\
\hline $\begin{array}{l}\text { ENFOQUE DAS } \\
\text { VIRTUDES }\end{array}$ & $\begin{array}{l}\text { "Eu acho que faz parte da formação dele, primeiro, assim, isso é } \\
\text { importante em termos da saúde dele e da mulher dele, isso é } \\
\text { importante assim, em termos, no pragmatismo extremo! Agora, a } \\
\text { longo prazo, eu acho que isso faz parte da formação dele enquanto } \\
\text { cidadão, do que ele vai passar pros filhos dele (....)" (M11) }\end{array}$ \\
\hline $\begin{array}{l}\text { ENFOQUE DO } \\
\text { CUIDADO }\end{array}$ & $\begin{array}{c}\text { "Eu tento convencer... o paciente, o cliente a contar pra sua esposa, } \\
\text { porque já que eles vivem, estão juntos, não tem que ficar escondendo } \\
\text { nada de... da esposa." (E8) }\end{array}$ \\
\hline \multicolumn{2}{|r|}{ ATENDENDO ADOLESCENTES } \\
\hline ENFOQUE & $\begin{array}{c}\text { "(...) contar aos pais eu não iria tá contando mesmo (....) prefiro que } \\
\text { a paciente se cuide (....)" (M7) }\end{array}$ \\
\hline PRINCIPIALISTA & $\begin{array}{c}\text { "Eu posso não concordar com isso, mas eu tenho que oferecer } \\
\text { condições pra ela escolher o que ela vai fazer, mas nunca escolher o } \\
\text { que ela vai fazer, nem os pais dela deveriam, né?!" (M10) }\end{array}$ \\
\hline $\begin{array}{l}\text { ENFOQUE DO } \\
\text { CUIDADO }\end{array}$ & $\begin{array}{c}\text { "E cativar essa paciente e conseguir cativar a familia, porque } \\
\text { devagarzinho, você cativando a paciente, você vai tá explicando pra } \\
\text { ela e tentando trabalhar com a familia de... de deixar a pessoa } \\
\text { namorar, a adolescente namorar." (E18) }\end{array}$ \\
\hline $\begin{array}{l}\text { ENFOQUE DA } \\
\text { ÉTICA } \\
\text { PROFISSIONAL }\end{array}$ & $\begin{array}{l}\text { "Porque se eu for falar direto com os pais, eu acredito que eu vou tá } \\
\text { passando por cima de um código de ética, desrespeitando o sigilo, } \\
\text { sigilo profissional e não prescreveria primeiro o anticoncepcional } \\
\text { (....) eu acho que os pais têm que tá cientes (....)" (E11) }\end{array}$ \\
\hline
\end{tabular}


No cenário 'Perturbando a Rotina' vale destacar que é possível denotar nos discursos que formulam o enfoque principialista o respeito à autonomia do usuário:

"(....) cada coisa tem seu tempo, não adianta a equipe se afobar, de querer ajudar o paciente se ele não está no momento de ser ajudado (....)" (E2)

"(....) é dito que faz-se o melhor possivel, será que esse melhor possivel é aquilo que os profissionais técnicos, no caso, médico e enfermeira acham que é o melhor possivel, ou esse é o melhor possivel pra este paciente?" (M4)

“(...) acho que também a vontade dele tem que ser respeitada (....) você passa todas as informações pro paciente, você não pode obrigar o paciente a... a fazer uma coisa que ele não quer." (M6)

Entretanto, este respeito à autonomia não implica em abandono, pois há uma preocupação em esclarecer ao usuário, no caso o senhor $\mathrm{C}$ com diabetes $\mathrm{e}$ hipertensão, acerca dos riscos de sua situação de saúde, movendo a ponderação no continuum da beneficência e não maleficência:

"Não, não pode (desistir). Não, tem realmente pensar que... ele... se ele deixar de continuar fazendo esse esforço, ele... ele não vai ter... um... vamos dizer assim outro caminho, ele vai deixar de tomar seus remédios, ele vai deixar de procurar a gente, né, e ai pode ter uma complicação e parar ai num hospital e realmente se a gente não tiver... vamos dizer, essa capacidade de resolver esse problema, a gente seria... como condená-lo... eu acho que a gente tem que lutar de qualquer forma (....)" (M14)

"Não, desistir, não! Porque, na verdade ele pode não tá tão consciente assim do tamanho do problema dele, então, você sempre 
tem que pensar que a ignorância vai acabar levando a problemas maiores, né?!" (M17)

“(...) muitas vezes o paciente não tem noção de gravidade do problema dele (....) e esse paciente, ele vai ser um acamado amanhã, ele vai ter complicações ele vai dar despesas muito maiores pro Estado, pra familia, vai sofrer muito mais. E você vai ter muito mais dor de cabeça se você não investir um pouquinho nesse paciente." (M18)

Ainda nas formulações principialistas do 'Perturbando a Rotina', é possível identificar uma posição, em certa medida, autoritária de alguns enfermeiros e médicos, fato também observado no momento I do estudo, quando estes profissionais apontam os seguintes problemas éticos nas relações com o usuário: "como informar o usuário para conseguir sua adesão ao tratamento"; "solicitação de procedimentos pelo usuário" e "recusa do usuário às indicações médicas". Isto remete aos comentários de Beauchamp e Childress (2001) relativos aos problemas encontrados no contexto da assistência médica para se efetivar o respeito à autonomia dos usuários dos serviços de saúde por causa da condição dependente deste e da atitude autoritária do profissional de saúde:

"Primeira coisa (...) você tem que explicar pra eles que não é bem assim, no momento que eles estão disponiveis e sim no momento que existe condição de fazer, tem uma rotina (....) (E14)"

“(...) esse paciente, independente dele tá sobrecarregando a unidade, tem que se dada a atenção e tem que ser, assim, padronizado cada vez mais esses procedimentos (....) o paciente tem que ter um limite (...) que é a regra geral do posto, não (....) uma regra que foi colocada pra ele (....) eu acho que a partir do momento que de uma maneira adequada você coloca as regras por paciente, ele passa a seguir. (M6)" 
"Eu acho que tem que programar uma rotina de esforços e deixar isso claro pro paciente (....) 'a terceira terça-feira de cada mês a gente vai tá aqui esperando o senhor' e deixar isto claro para ele, quando ele se dispuser a ir, ai ele vai ser bem atendido, como todos outros. Mas não no dia que ele quer, porque tem uma programação. (M10)"

"Eu acho que primeiro você tem que sentar com ele e colocar as coisas nos devidos lugares: 'o senhor é usuário, o senhor tem o direito de passar como todos que são usuários também têm o direito de passar! O senhor é hipertenso e diabético como trocentos também são e respeitam horários e regras e consultas e tudo isso! $O$ posto não é só seu! É de todo mundo! Se o senhor não se enquadrar dessa maneira, o senhor não vai poder ser assistido da maneira que o senhor quer (....)' (M17)"

Também nos depoimentos que formulam o problemas ético de maneira mais próxima dos enfoques do cuidado e das virtudes, é possível observar esta atitude de cunho autoritário:

“(....) então de tanto a gente bater ele acaba fazendo o que a gente quer (....) (E8)"

"esse tipo de paciente a gente tem que acolher (....) mas explicar que não pode ser do que jeito que eles querem e sim do jeito que a gente acha que deve ser." (M13)

“(....) o paciente, ele vem pro posto pra ser atendido, ele não imagina que tem uma rotina ou como que funciona a unidade (....) nesse caso aqui, eu acho que tem que sentar, na hora que ele venha na consulta dele, explicar como é funcionamento (....) ele aceita $e$ 
continua acompanhando ou ele vai desistir e vai pra outro lugar (....) (M8)"

$\mathrm{Na}$ atenção à saúde, não parecem raras as práticas perpetuadoras da dependência do usuário, em lugar de se buscar a promoção de sua autonomia e cidadania. Isso equivale a percorrer os trilhos da beneficência paternalista com seus traços de superproteção, inibição, infantilismo e, em certa medida, de autoritarismo que descrevem atitudes do tipo 'eu sei o que é melhor para você'. Na enfermagem, esta atitude reveste-se de uma nova nuança, pois o processo de trabalho dos enfermeiros é marcado pela utilização de protocolos ou rotinas de cuidados e procedimentos que, supostamente, atendem às necessidades de quase todos os usuários, na maioria das vezes. É bastante comum a enfermagem encaixar a assistência dispensada a uma pessoa ou a um grupo numa rotina estabelecida, não importando se essa é congruente ou não com as condições de quem procura ou precisa de sua atenção. Parece que se instala o "paternalismo burocrático", no qual as normas, os procedimentos e as rotinas determinam o que deve ser feito, não importando o que é melhor ou mais indicado, ou, ainda, o que o usuário autonomamente demanda. Os usuários são, então, rotulados de "colaboradores" e "não colaboradores", sendo que os primeiros, geralmente, recebem o cuidado sem questioná-lo, ao passo que os últimos, de uma forma ou outra fazem-no (ZOBOLI e MASSAROLLO 2002).

Em relação à afirmação do parágrafo anterior, quanto às peculiaridades do enfermeiro, vale a ressalva que, a partir dos discursos analisados no presente estudo, é possível apontar que, dentre os entrevistados, o "paternalismo burocrático" não se restringe a este grupo profissional, também aparecendo nos médicos, inclusive com um evento a mais (4 enfermeiros e 5 médicos).

Beauchamp e Childress (2001) afirmam que nas instituições onde as pessoas são admitidas involuntariamente, como as prisões, as violações ao princípio do respeito à autonomia ficam explícitas, mas onde a admissão é voluntária, este comprometimento das escolhas autônomas pelas regras, políticas e práticas 
institucionais, freqüentemente, é sutil. Citam como exemplo os asilos para idosos, ponderando que a liberdade dos residentes destas instituições para viver de acordo com suas preferências e planos de vida deve ser balanceada com a proteção de sua saúde; a proteção dos interesses dos demais internos; a promoção da segurança e eficiência da instituição e a alocação dos limitados recursos. Neste contexto, segundo os autores, muitos contestam o respeito à autonomia, afirmando que este configura uma exigência demasiado pesada para estas organizações e propõem, em lugar do consentimento informado, o "consentimento negociado" que enfatiza os deveres mútuos em vez dos direitos individuais. Alternativa que os autores consideram arriscada sem o estabelecimento de proteções claras à vulnerabilidade dos residentes (BEAUCHAMP e CHILDRESS 2001).

Guardadas as devidas proporções, parece possível traçar um paralelo destas considerações com a atenção básica prestada na USF, especialmente porque o contato dos profissionais com o usuário, a exemplo do que ocorre nas instituições asilares, perdura por longo período e o modelo de consentimento proposto pelos enfermeiros e médicos aproxima-se desta negociação em relação às normas e rotinas. Cabe inclusive o alerta quanto à vulnerabilidade, pois, como já abordado no momento I e também observado nos trechos de depoimentos transcritos a seguir, o usuário, muitas vezes, é visto pelos profissionais das equipes como alguém que não conta com outros equipamentos de atenção à saúde aos quais possa recorrer, o que lhe imprime certa vulnerabilidade, que deveria ser alvo de proteção, com vistas a promover sua autonomia e cidadania:

“(...) o paciente tá aí, ele é da equipe, depende da equipe (....)" (E7)

“(...) as pessoas, elas não têm dinheiro nem pra pegar uma condução, pra fazer nada né! E acaba sendo o único ponto de contato aqui no posto. Porque elas só conseguem desabafar, elas só conseguem encontrar as pessoas conhecidas aqui dentro (....) então acabam vindo aqui no posto, inventando qualquer coisa, pelo menos, pra ter uma desculpa pra tá aqui dentro." (M11) 
Esta vulnerabilidade também pode ser vista sob outro ângulo quando os profissionais apontam, nas entrevistas, as normas e diretrizes do PSF como determinantes do vínculo que se estabelece entre estes e os usuários, elucidando-se uma falta de opção de ambos lados:

"Porque esse paciente (...) ele tá entre essas 1.200 familias, se ele tiver qualquer complicação, devido a diabetes ou à hipertensão arterial, sempre vai ser responsabilidade da equipe e a equipe vai ter que lá na frente, dizer porque que o senhor fulaninho morreu com 46 anos de $A V C$, que era uma que a gente poderia... entendeu, $e$ a gente vai ter que apresentar um relatório dizendo (....) como é que tava o acompanhamento desse paciente, ver no prontuário as consultas que ele vinha, o que que ele disse (....) esse paciente sempre vai ser nosso, não tem como assim você abandonar esse paciente (...) desvincular dentro do PSF é dificil você tá... tá desvinculando não tem como." (E10)

"Porque ele tem direito de tá usando o posto, a tá usando o serviço de nossa equipe, tem que ter esse vínculo, ter um vínculo mesmo, então a gente faz toda essa articulação. Como eles não escolhem os profissionais, nós também não escolhemos pacientes, a gente tem que tá prestando da mesma forma para todos (....)" (E3)

É claro que não se advoga com isto que os profissionais de saúde desprezem as rotinas que tão bem se prestam a organizar os serviços, melhorando seu fluxo e o processo de trabalho. $\mathrm{O}$ absurdo está na sua conversão em pautas rígidas a ordenar condutas. Isto talvez possa ser evitado pela ponderação dos princípios de não maleficência e beneficência que é feita pelos enfermeiros e médicos, embora mesmo no momento de prevenir danos ou eliminar condições que possam causá-los, o cumprimento das normas continua gozando de importância especial: 
“(....) é claro, se é um hipertenso, a gente pede pra medir a pressão na hora, se tiver alta a gente vai tratar, mas não vai ser uma consulta que a gente vai pedir exame, vai pesar, vai medir altura, vai ser uma ... um pronto atendimento, a gente vai direcionar pra aquela queixa. Não vai ser uma consulta normal, porque o paciente que não tá acostumado a cumprir com o horário" (M10)

“(....) a não se que requer: o paciente chega ai com uma dor no peito, tem que ser atendido na hora, né! Mas a não ser que requeira um atendimento imediato, tem que tá impondo limites." (E13)

Nas formulações principialistas do 'Perturbando a Rotina', ainda merecem destaque as citações que remetem ao princípio da reciprocidade, entendido como o ato ou a prática do retorno apropriado e, freqüentemente, proporcional, conforme especificado por Beauchamp e Childress (2001). Este, porém, aparece como a obrigação do usuário em aderir às indicações terapêuticas em troca da assistência que recebe:

“(...) nós temos os nossos deveres enquanto profissionais de saúde e o paciente também tem o dele (....)" (E13)

"(....) tem que investir independente do que... pelo menos o seu cinqüenta por cento você fez. Se no final o resultado não for esse, pelo menos os seus cinqüenta por cento foi feito né! Agora é tentar não abrir mão e tentar mostrar assim que os cinqüenta por cento do paciente, a importância disso, pra ele que (....) às vezes a pessoa não tem a real importância que isso tem." (E17)

“A responsabilidade maior é dele (....) a nós cabe a nossa parte, a responsabilidade é do paciente (....) a nossa parte seria essa: de tecnicamente tá assistindo, tá ouvindo, intervindo, medicando, 
esclarecendo (....) acho que é dividir a responsabilidade, a minha é essa e a sua é essa." (M17)

Jacobson (2000), ao discutir consentimento e adesão na atenção primária, afirma que há quem defenda que os usuários dos serviços de saúde têm um dever moral de cumprir as instruções prescritas. Esta obrigação decorreria da relação profissional de saúde-usuário compreendida nos seguintes termos: "quando o médico realiza seu serviço o paciente é obrigado a corresponder reciprocamente pela adesão às recomendações médicas ao deixar o consultório". Entretanto, como alerta o autor, cabe aos profissionais, e não aos usuários dos serviços de saúde, a responsabilidade por incrementar a adesão aos projetos terapêuticos (JACOBSON 2000. p. 43).

Nos depoimentos, além desta responsabilidade pela adesão ser delegada ou ao menos dividida com os usuários, pode-se ainda identificar uma inclusão dos agentes comunitários de saúde nesta tarefa, com o papel de protagonistas:

“(...) por mais dificil, por mais, por maior problema que seja, que ele assim, não desista de cobrar a equipe, seja do médico, da enfermeira, do auxiliar (....) o agente comunitário tá na área é que leva as 'burduadas' que tem que levar! (....) o agente comunitário não pode desistir nunca, porque se ele desiste a equipe vai deixar de lado, porque o médico e a enfermeira, quando é que vai lembrar de novo desse caso aqui desse paciente, só vai lembrar quando ele vier de novo aqui na unidade, pedir pra ser atendido e pertube a rotina como é que tá escrito aqui (....) ele não cobrou, eu esqueci! Ai fica sendo como que eu não dei... e a responsabilidade cai toda por cima de quem, ou do médico ou da enfermeira, então como a gente é uma equipe, não dá pra acontecer isso (....)" (E14)

Merece ser mencionado que no 'Perturbando a Rotina' há um ponto que chama a atenção nas respostas dos enfermeiros e médicos. A narrativa, tal como apresentada aos entrevistados, não especifica se o senhor $C$ segue ou não as 
prescrições e indicações médicas e de enfermagem, apenas diz "freqüentemente faz demandas que dificultam as atividades e perturbam a rotina da unidade de saúde". A inferência de que ele seria um usuário que não segue os tratamentos prescritos talvez seja motivada por ser esta uma ocorrência comum nas unidades, conforme apontam os próprios entrevistados ao elencarem como problemas éticos no momento I: "como informar o usuário para conseguir sua adesão ao tratamento" e "recusa do usuário às indicações médicas". Uma outra explicação plausivel, ainda, poderia ser a associação entre adesão ao projeto terapêutico e adequação às normas e rotinas da unidade que parece estar subsumida nos rótulos "colaborador" e "não colaborador".

Vale notar, contudo, que este entendimento não é unânime, havendo registros de quem valorize o senhor $\mathrm{C}$ estar constantemente na unidade e entenda isto como adesão ao tratamento:

"Não (desistir), nunca! Nunca, pelo seguinte: a gente faz o contrário, a gente, enquanto equipe, a gente vai buscar aquele que não comparece à consulta (....) esse dá mais trabalho do que aquele que tá direitinho, controlado, ele não dá trabalho nenhum! Então ao contrário daquela pergunta que você fez, é o inverso daquele. " (M9)

“(...) a nossa meta (...) são os resistentes, porque os que estão vindo já estamos vendo (....)" (E13)

Nas formulações de enfoque principialista para o 'Preservando a Confidencialidade', aparece claramente o conflito entre as obrigações morais da veracidade e confidencialidade que, como alertam Beauchamp e Childress (2001), podem ser vivido pelos profissionais de saúde quando uma terceira parte entra em jogo na relação clínica:

“(...) nessa situação eu acho complicado manter o sigilo porque é uma coisa que ela tem o direito de saber (....)" (E6) 
“(....) é uma informação que... que tem o direito a saber e nós como profissionais de saúde a gente não tem o direito também de não dar essa informação a ela." (M15)

“(....) claro que você não faria nada sem o consentimento dele, por outro lado, você não poderia fazer o que ele está pedindo (....)" (M16)

Na ponderação deste conflito, alguns dos entrevistados atribuem maior peso à obrigação de proteger a confidencialidade do senhor $\mathrm{N}$ e consideram a possibilidade de enganar a mulher a fim de solicitar o exame:

"acho que a gente poderia (....) convocar... não convocar, o papanicolaou é assim: os agentes passam numa casa e quem não fez papanicolaou pergunta se tem interesse de fazer (....) e no papanicolaou, como a questão da saúde da mulher envolve outros requisitos, a gente podia tá oferecendo e perguntando se a paciente não teria interesse de tá fazendo (....)" (E13)

“(....) esse paciente com... com sifilis, né, se ele tem na (....) na consciência dele que ele traiu essa esposa, né, mas ele quer proteger essa esposa, porque ele gosta dela (....) a gente tem que seguir o que ele tá falando. A gente vai ter que tratar desse paciente, encaminhar (....) a esposa dele pra fazer papanicolaou porque é rotina (....) ou alegar alguma coisa (....) uma desculpa feita pelo paciente se a paciente não tiver mesmo numa fase de fazer papanicolaou (....) tem que forçar ela vim pra unidade e falar olha, ele tá com um problema que você também pode ter (....) não é um problema transmitido numa relação sexual (...) são mentirinhas que eu acho que até...necessárias. Você vai criar um conflito conjugal, não é nossa área, nosso departamento! A gente não tem nada a ver com 
isso, a gente tem que tratar dos dois e no dia que ele quiser contar para esposa ele conta; porque é problema dele." (M6)

Esta opção de enganar a mulher, presente em ambos grupos profissionais e gêneros, parece configurar o que Beauchamp e Childress (2001) chamam de "manipulação", um termo genérico para designar várias formas de influência que não são nem persuasivas ou tampouco coercitivas. A essência da manipulação é levar as pessoas a fazerem o que o manipulador quer, por outros meios que não a coação ou persuasão. Na atenção à saúde, segundo os autores, a forma mais comum de manipulação ocorre com a informação. Num ato deliberado, lida-se com esta de maneira não persuasiva, com vistas a alterar o entendimento da pessoa acerca da situação e motivá-la a fazer o que o agente influenciador pretende. Muitas formas de manipulação da informação são incompatíveis com a tomada de decisão autônoma, sendo os exemplos mais freqüentes a mentira, a omissão e o exagero desmedido na sua transmissão (BEAUCHAMP e CHILDRESS 2001).

Cabe salientar que, em alguns casos, a manipulação da informação é vista como momentânea ou condicionada, isto é, não exclui terminantemente a possibilidade de contar a verdade que fica, então, dependente de ponderações acerca das circunstâncias do caso possíveis de causar danos, incluindo o resultado do exame e a época e freqüência dos relacionamentos extraconjugais:

"se o exame dela der positivo, ai eu teria que chamar os dois pra tá conversando, no caso dele não querer falar pra ela, porque se o exame dela vem positivo, ai não tem outro jeito. (....) se veio negativo, tudo bem, eu não vou chegar e vou contar." (M8)

“(....) se foi um episódio fortuito, ai, tenta...contorná-lo e fazer com que ela peça o exame, se é uma coisa rotineira (....) que ele sempre tá traindo ela (....) ou usando droga, acho que, nesse caso, teria sim que conversar com esse senhor (....) e tá convencendo ele de que realmente a esposa precisa ser avisada (....)" (M15) 
Pesquisa realizada com 131 médicos de Illinois sobre problemas éticos encontrados na prática de medicina da família aponta que se um paciente do sexo masculino contraísse doença sexualmente transmissível, infectasse sua esposa, não quisesse contar a verdade e pedisse que ela fosse tratada sem saber de sua condição, os profissionais resistiriam ao pedido e favoreceriam dizer a verdade para a esposa, tratando-a abertamente (DAYRINGER e col. 1983).

Recomendação idêntica aos achados da pesquisa citada é encontrada em 9 depoimentos do presente estudo, sendo 5 de enfermeiros e 4 de médicos. Embora não exclusivamente, esta alternativa de solução aparece claramente nas formulações pautadas no enfoque do cuidado, denotando uma preocupação em proteger os vínculos familiares, a ponto dos profissionais considerarem a possibilidade de ajudarem o senhor $\mathrm{N}$ a conversar com a esposa:

"Eu tento convencer... o paciente, o cliente a contar pra sua esposa, porque já que eles vivem, estão juntos, não tem que ficar escondendo nada de... da esposa." (E8)

"Eu acho a maneira mais sensata de você resolver a situação é tá envolvendo as duas pessoas que estão diretamente ligadas à situação, porque também ficaria numa situação dificil você conversar com a mulher, até, não sei, longe do marido, alguma coisa assim, né, pareceria uma coisa mais do profissional e deixar um ou outro meio do lado. Eu incluiria também o marido nessa situação." (E10)

"Eu acho que teria que convencê-lo a falar pra esposa (....) que ele venha junto, nem que a gente converse junto com ele, tentando explicar o porque daquilo, que acho que vai gerar um conflito no casal (....)" (M13) 
"se o senhor não quer contar (....) sozinho, então vem os dois aqui, a gente vai conversar. Então na verdade, eu taria fazendo uma tentativa de estar minimizando o problema (....)" (M8)

A opção por tal curso de ação também se justifica na responsabilidade do senhor $\mathrm{N}$ para com a saúde de sua esposa, numa rede de relacionamentos e responsabilidades mútuas:

“(...) a pessoa tem que ir lá conversar com o companheiro, até porque é responsabilidade dele. E se ele tá orientado que é uma doença transmitida através de relação sexual, a companheira dele corre o risco de ter o problema e até vir a adoecer, ter outra complicação, então é a responsabilidade dele, é a saúde e vida dela (....)" (E14)

Ainda é possível notar que se inclui neste tipo de recomendação uma aposta na solução não violenta do conflito, por meio da comunicação:

"Eu acho que a alma do negócio é a conversa! Conversando, a gente se entende!" (M11)

As preocupações em fortalecer ou não romper as relações de vínculo e de resolver os conflitos de maneira não violenta por meio do diálogo também estão presentes nas recomendações feitas pelos entrevistados no 'Atendendo Adolescentes', caracterizando o enfoque do cuidado na formulação do problema ético deste cenário:

"Em primeiro lugar eu identificaria a posição dos pais, são pais, né, que convivem com ela, né. Não quer que namore, né. Eu trabalharia melhor esses...recomendaria que trabalhasse melhor esses pais, né. É proibindo que vai se resolver o problema? Não! É melhor orientá- 
la e dar uma boa orientação pra ela. E deixar que ela decida, por mais que ela tem 15 anos de idade, né." (E9)

“(...) se possivel trazer o namorado aqui, a gente conversaria junto, quanto a não dizer pros pais (...) me oferecer para ajudá-la a contar pra mãe e pro pai (....) acho que a função nossa aqui, tanto médico, da enfermeira e do agente comunitário" (E16)

"Tem que falar para os pais, mas com a menina junto, a paciente. Primeiro você cria um vinculo com essa menina, depois cria um vinculo com os pais e ai fala pra ela: 'é importante porque a gente não vai assumir a responsabilidade de qualquer gravidez e você vai ter que ter a ajuda desses pais e pra eles ajudarem, eles têm que tá sabendo que isso é importante, né, pra esse namoro, pra você, tudo.'." (E19)

"Ver, com muita conversa, de que forma que você pode... fazer com que ela... ela consiga chegar num diálogo com esses pais (....) num primeiro momento até poderia prescrever sem os pais saberem, um... um anticoncepcional sim (....) o uso do preservativo (....) para prevenir, é a prevenção de gestação indesejada, as doenças sexualmente transmissiveis, a quebra do vinculo familiar." (M4)

Também se expressa uma tentativa de alcançar a felicidade de todos e não magoar ninguém, elementos característicos da ética do cuidado:

"Então vamos marcar uma consulta, vem com sua mãe! E vamos conversar com a sua mãe, pra que ela converse com o pai e pra que essa menina inicie uma vida afetiva e mesmo depois, sexual, conforme a opção dela, de forma saudável e segura e que isso seja saudável e seguro pros pais. $O$ fato da filha se iniciar na 
sexualidade não seja um motivo de conturbação da família, não mexa com a estrutura familiar." (M4)

A aposta na comunicação como maneira de conduzir uma solução para o problema acontece mesmo que a recomendação não inclua a prescrição do anticoncepcional para a adolescente e o enfoque da formulação do problema seja o da ética profissional:

"Porque se eu for falar direto com os pais, eu acredito que eu vou tá passando por cima de um código de ética, desrespeitando o sigilo, sigilo profissional e não prescreveria primeiro o anticoncepcional (....) eu acho que os pais têm que tá cientes, mas não sou seu que vou chegar e falar: 'olha, sua filha vai tomar pilula.' Tentaria trazê-la pra ela se conscientizar disso e posteriormente, se possivel, taria conversando junto com a familia toda." (E11)

Neste sentido, vale destacar que no 'Atendendo Adolescentes' somente um dos depoimentos não recomenda a prescrição, o do enfermeiro E11, conforme se observa na transcrição acima. Os demais aconselham a indicação da anticoncepção e alguns até do uso do preservativo para prevenção tanto de gravidez indesejada, quanto da transmissão das doenças sexualmente transmissíveis, retratando o princípio da utilidade, conforme definido por Beauchamp e Childress (2001), e que consta do referencial teórico do presente do estudo, isto é, um balanço dos benefícios, custos e danos com vistas a alcançar o maior benefício líquido:

“(....) sabe lá se não vai tem mais uma adolescente tentando tomar anticoncepcional, você vai ter uma adolescente grávida na sua mão com muitos...muitos grilos e a familia toda batendo na sua porta! E ainda se for só uma gravidez tá bom. Se não vier uma DST, uma aids. A gravidez a gente dá jeito! As outras é um pouco mais dificil." (E18) 
Estes achados guardam consonância com os da pesquisa realizada com médicos de família em Illinois que, além de indicar que os problemas éticos relativos à contracepção são comuns na prática diária, revelam uma disposição destes profissionais para prescrever contraceptivos às adolescentes que os peçam, ainda que sem permissão dos pais. Do total de 131 respondentes, 76\% prescreveriam; 13\% refeririam para um serviço especializado e somente $11 \%$ se recusariam a ficar envolvidos (DAYRINGER e col. 1983).

O fato dos profissionais recomendarem a prescrição não significa que desconheçam as limitações legais relativas à maioridade, manifestando preocupação com esta questão:

“(....) ela tem o direito, mas é um direito entre aspas né, porque a gente não tem... na verdade, se acontecer alguma coisa, a gente não pode... pra menor assim." (E17)

“(...) nós estamos com um menor de idade, até os 18 anos os pais são responsáveis, isso é o que a lei diz. A realidade atual é outra (....) são coisas com que a gente tem que lidar. $O$ que pode dar algum problema (....) vamos tá fora da lei" (M4)

Neste sentido, um depoimento chama a atenção por entender como "Constitucional" o direito da adolescente ao sigilo:

"(....) é um direito dela. É um direito até Constitucional dela. $O$ sigilo dela deve ser mantido, é um direito dela, não é porque é adolescente que não tem esse direito." (M9)

Estes depoimentos apontam para a diferença existente entre a abordagem jurídica e a ética no que tange à noção de competência decisória dos adolescentes, sendo, como afirma Fortes (1998), polêmica a discussão sobre a competência ética do adolescente em decidir sobre questões relativas à sua saúde. Segundo o autor, para 
os adolescentes, defende-se a noção de "maioridade sanitária" que se diferenciaria da "maioridade legal" pela análise da competência decisional do adolescente, ou seja, qualquer pessoa, independente de idade, com condições intelectuais e psicológicas para apreciar a natureza e as conseqüências de um ato ou proposta de assistência a sua saúde pode tomar suas decisões. Para o autor, o Código de Ética Médica, em sua última edição, incorpora a noção da maioridade sanitária, sem mencioná-la expressamente, pois em seu artigo 103 possibilita aos profissionais ocultarem informações a respeito de pacientes menores de idade, quando julgarem que estes tenham competência para decidir a partir de avaliação adequada de seus problemas de saúde, aplicando-se esta regra também aos pais ou responsáveis legais (FORTES 1998).

Neste sentido, poder-se-ia entender que o Código de Ética dos Profissionais de Enfermagem vigente também deixa espaço para se operar com a noção de maioridade sanitária ao determinar, em seu artigo 27, o dever de se "respeitar e reconhecer o direito do cliente de decidir sobre sua pessoa, seu tratamento e seu bemestar", sem estabelecer limites de idade para tal. A questão do sigilo, que é tratada no artigo 29, obriga a "manter segredo sobre fato sigiloso de que tenha conhecimento em razão de sua atividade profissional, exceto nos casos previstos em Lei" (COFEN 2000).

A Lei paulista que dispõe sobre os direitos dos usuários dos serviços de saúde e das ações de saúde no Estado (Lei n 10.241 de 18/03/1999) determina que todos devem ter resguardado o segredo sobre seus dados pessoais, através da manutenção do sigilo profissional, desde que não acarrete riscos a terceiros ou à saúde pública (art. $2^{\circ}$, item IV).

Segundo Halevy (2000) os adolescentes mostram-se mais inclinados a procurar assistência e a confiar nos profissionais quando lhes é assegurado, ao menos, algum grau de privacidade e confidencialidade. Entre os enfermeiros e médicos entrevistados, pode-se notar este empenho em assegurar a preservação da confidencialidade, tornando isto claro para os adolescentes: 
“(...) às vezes se vem acompanhado da mãe, eu pergunto se ele quer que a mãe saia da sala (....) muitos dizem que quer que a mãe saia (...) ele teme que pra isso tenha algum problema, que digo que não. Então eu peço pra ela sair, ele conversa só comigo" (E12)

"Se mãe quiser saber alguma coisa a gente sempre consulta o adolescente: 'podemos passar ou não?'(....)" (M9)

“(....) eu não vou contar porque eu sei que se um dia ela tiver um problema, ela vai vim me procurar e eu vou poder ajudar, agora se eu trair a confiança dela (....) ela não vai mais me procurar e ai para restabelecer o vinculo com ela, vai demorar muito tempo." (E15)

“(...) falaria pra ela que não iria dizer, que isso quem teria que dizer seria ela, que o prontuário não tem, apesar de ser de familia, mas que o pai dela tem acesso ao prontuário dele, ele pode ver na hora que ele quiser, não o dela (....)" (E16)

Pesquisa realizada com 711 estudantes universitários, entre 16 e 21 anos de idade, ingressantes nos cursos de administração de empresas, direito, enfermagem, medicina e odontologia da Pontifícia Universidade Católica do Rio Grande do Sul no primeiro semestre de 2000 , identifica que a confiabilidade e a honestidade são características valorizadas como "muito importantes" por mais de $90 \%$ dos entrevistados, sendo um fator facilitador do retorno à consulta médica. Quando se analisam as freqüências combinadas das respostas "muito importante" $\mathrm{e}$ "importante", a confiabilidade aparece em primeiro lugar com 99,9\% (710), seguida da honestidade com $99,4 \%$ (707). A confidencialidade é tida como uma obrigação de todos os médicos e um direito de qualquer paciente, independente da idade por $75,9 \%$ (540) e $66,5 \%$ (473) dos sujeitos, respectivamente. Perguntados se o fato do paciente ser adolescente interferiria na guarda do segredo, $441(62,5 \%)$ respondem 
negativamente. Reconhecem, entretanto, que frente a informações que constituam risco para sua própria vida (câncer, aids, doenças mentais) ou para a vida de outras pessoas conhecidas (doenças contagiosas, aids, intenção de homicídio) o segredo pode ser quebrado, com mais de $70 \%$ dos estudantes pesquisados admitindo a revelação da informação para a família nestas situações (LOCH 2002).

Idealmente, na opinião de Halevy (2000), os profissionais de saúde que cuidam de adolescentes deveriam incluir, em seu primeiro atendimento, uma conversa sobre confidencialidade, discutindo este ponto não só com o adolescente, como também com os pais, a fim de esclarecer o que pode e será mantido em segredo e o que deve e será revelado aos pais. A sugestão de se discutir previamente este aspecto ético da relação com os usuários não parece de difícil implementação no PSF, pois se poderia introduzi-la, não somente nas consultas médica e de enfermagem, como nas visitas domiciliárias que os agentes comunitários de saúde fazem periodicamente às famílias, nas pautas dos diversos grupos que ocorrem nas USF, podendo até se planejar grupos com as famílias dos adolescentes, caso estes ainda não ocorram.

Os depoimentos também revelam um aspecto importante do princípio da justiça, como entendido por Beauchamp e Childress (2001), a distribuição dos bens e recursos de maneira justa, eqüitativa, apropriada e determinada por normas justificadas. Se no tocante à macroalocação são essenciais as políticas públicas, na microalocação parece ter peso também, além ou em conseqüência destas, as normas internas das USF que, muitas vezes, são determinadas pelos próprios profissionais ou equipes, unilateralmente. Tanto é assim, que também no momento I esta questão é levantada pelo grupo dos enfermeiros que identifica na "restrição do acesso dos usuários aos serviços" um problema ético. Seguem-se trechos de depoimentos colhidos nas recomendações ao 'Perturbando a Rotina':

“(...) eu entrei há um ano e meio, então, eu peguei a equipe no meio, tinha uma rotina deles, ai até eu fazer um mix das duas demorou um pouquinho (....) a politica era não deixar o paciente 
sem atendimento, podia vir duzentos pacientes, tinha que atender os duzentos! Ai eu comecei a conversar (....) porque a gente nunca ia conseguir dar conta da demanda, porque a qualidade desses duzentos era uma droga (....) ai eu diminui o agendamento pra dezessete, dezoito e agora eu tô conseguindo atender onze. E tô atendendo bem pra caramba, os pacientes saem super satisfeitos comigo. Tem os outros que ficam inconformados, que querem o pronto atendimento(....)" (M10)

“(...) nós temos uma estratégia, uma proposta de trabalho (....) hipertenso e diabético não marca consulta, eles são todos classificados, se ele é do grupo $C$, ele passa com o médico a cada 6 meses com todos os exames, se ele é diabético, ele passa com o médico a cada 3 meses (....)" (E13)

O que vem a ser o suficiente, que poderia ser, em certa medida, visto como a garantia de acesso igual ao mínimo decente, acaba se concretizando na prática dos profissionais, segundo seus próprios critérios que incluem a ponderação do beneficio ao usuário:

“(....) ele não precisa tá aqui no posto todo dia pra medir a pressão, ele não precisa tá aqui no posto todo dia pra ver como tá o diabete dele, a gente oferece esse serviço uma vez por mês e pros pacientes que consegue controlar e que a gente consegue convencer do auto cuidado é suficiente." (E15)

Isto não quer dizer que os profissionais percam de vista a questão de âmbito macro, sendo que atender às necessidades de saúde da área de cada equipe, dando conta da universalidade e eqüidade que são pilares do SUS configura uma preocupação que aparece nos depoimentos: 
"No PSF, o paciente não escolhe com que médico ele quer passare nós não escolhemos o paciente também, a área é definida $e$ procuramos tá atendendo toda aquela área de uma forma que cada paciente necessite, não de forma igual, mas com eqüidade, conforme a sua necessidade a gente vai tá atendendo a sua necessidade e isso pra todos (....)" (E3)

Nesta premência de dar resposta às necessidades dos usuários e suas famílias, os profissionais evidenciam em seus discursos a sobrecarga que isto acarreta:

“Às vezes me sinto desgastada e não quero mais tá recebendo aquele paciente porque já não tenho mais paciência, tô cansada de tá tentando e parece que vai no vazio, então a gente vai rodiziando entre a equipe." (E3)

"No fim do ano, quando a gente fez o planejamento, um querendo esganar o outro (....) porque tava todo mundo num nivel de stress que a coisa realmente extrapolou" (M11)

No Brasil, em pesquisa nacional realizada com enfermeiros e médicos do PSF, mais de $60 \%$ destes profissionais consideram trabalhar no Programa uma atividade desgastante, sendo apontadas como as principais causas para tal o excesso de trabalho causado pelo grande número de famílias; a falta de recursos humanos, materiais e medicamentos; a dificuldade de acesso às áreas de trabalho; a baixa remuneração e a falha no sistema de referência e contra-referência (MACHADO 2002).

Ao menos parte destes problemas são identificados pelos enfermeiros e médicos entrevistados, no momento I, como questões éticas: "excesso de famílias adscritas para cada equipe"; "demérito dos encaminhamentos feitos pelos médicos do PSF"; "dificuldades no acesso a exames complementares"; "dificuldades quanto ao retorno e confiabilidade dos resultados de exames laboratoriais" e "falta de 
retaguarda de serviço de remoção". Assim, parece que as soluções devem envolver mudanças estruturais no sistema de saúde, devendo ir muito além do rodízio praticado entre os membros da equipe no atendimento.

Segundo Alves Sobrinho e Souza (2002), este comprometimento na continuidade da atenção básica prestada pelas ESF, decorrente da ineficiência e ineficácia do sistema de referência e contra-referência, deve-se à ausência de diálogo entre as Secretarias Estaduais e Municipais de Saúde, sobretudo nas capitais, onde os governos são de partidos opostos e à falta de acordo técnico, normativo e programático em torno da oferta das ações e serviços de saúde que requerem equipamentos sociais de suporte à atenção básica, como hospitais, ambulatórios de especialidades e outros.

Em relação ao enfoque das virtudes na formulação dos problemas éticos constantes nos cenários hipotéticos apresentados aos entrevistados, sem desconhecer as considerações de MacIntyre (1984) de que o processo de trabalho desenvolvido pela maioria dos habitantes do mundo moderno não pode ser entendido em termos da natureza de uma prática com bens internos, optou-se por buscar nos discursos uma percep̧̧ão da atenção à saúde como uma prática deste tipo de bem.

Esta escolha tem algumas justificativas. A primeira decorre do próprio comentário de MacIntyre (1984) que vê esta questão como uma dificuldade a ser enfrentada por sua concepção de virtude e não uma impossibilidade de concretização. Em segundo lugar, Sellman (2000), traçando um paralelo entre a noção de prática proposta por MacIntyre e a enfermagem, afirma que muitos dos que ingressam no exercício desta profissão o fazem, geralmente, por razões altruísticas, sendo plausível sugerir, na sua opinião, que a atividade de enfermagem pode ser concebida como portadora de recompensas internas diretamente relacionadas à satisfação de ajudar aos outros. Além disso, Wainwright (2000), comentando a proposição de Sellman (2000), corrobora a validade de pautar a enfermagem pela concepção de prática delineada por MacIntyre (1984), embora entenda que seu bem 
interno consista em assistir às pessoas na sua persecução de bem estar e aprimoramento e não no auxílio altruísta.

A elaboração pautada no enfoque das virtudes aparece no 'Perturbando a Rotina', com 3 depoimentos de enfermeiros e 4 de médicos e no 'Preservando a Confidencialidade', com 1 médico. No primeiro cenário, é possível identificar a busca, no exercício da profissão, por algo que ultrapassa a "sobrevivência biológica", a "reprodução da força de trabalho" ou a "ganância institucionalizada", que são tidas por MacIntyre (1984) como empecilhos à concretização, no mundo moderno, das práticas que servem de base para as virtudes:

“(...) se eu desistir aqui (na USF), é melhor que eu desista lá (no hospital) também, né. Eu não vou fazer nada... fazer nada... vou só pensar em ganhar dinheiro, vou sentar aqui e ver sua queixa e fazer o que tem que fazer, só isso?! Por que? Aí levanto às 7 horas e falo: 'vou pra aquele trabalho chato de novo!'. O dia que eu me sentir assim eu mudo de profissão, é o dia que eu desisti da senhora em questão, um dos casos... aí eu vou ser engenheiro, entendeu?! Então não pode desistir nunca, entendeu?! E o grande problema da questão da ética é aqui: as pessoas não sente o problema, às vezes estão aqui pelo salário ou pelas oito horas diárias, não trabalha nem sábado, nem domingo, nem feriado... ai a gente sente que não existe aquele compromisso, entendeu?! Há falta de compromisso..." (E9)

"Não desistir porque é o nosso lema, acho que o profissional de saúde, ele sempre tem que continuar e tentar. Agora se ele acha que não vale a pena, acho que ele deve desistir e também sair da profissão, porque ai ele não vai conseguir fazer mais nada... dentro dessa área." (E11) 
No depoimento que formula o enfoque das virtudes no 'Preservando a Confidencialidade', parece ficar patente uma compreensão de que as qualidades necessárias para conseguir os benefícios à saúde dos usuários podem contribuir para o bem de sua vida como um todo e até mesmo para a construção de sua cidadania:

"Eu acho que faz parte da formação dele, primeiro (....) isso é importante em termos da saúde dele e da mulher dele (....) no pragmatismo extremo! Agora, a longo prazo, eu acho que isso faz parte da formação dele enquanto cidadão, do que ele vai passar pros filhos dele, pelo menos a noção de respeito, tá, dele entender que isso eu estou fazendo porque eu o respeito enquanto paciente... de que eu respeito a esposa dele. E de que isso ele vai querer passar pros filhos dele também, né, porque ele vai querer que quando a filha dele for casada, o esposo tenha a mesma atitude! Eu acho que essas coisas tem que começar a... a entrar na cabeça deles, né, que as coisas não podem ser levadas da maneira que tão sendo levadas. Não, a gente conta uma mentirinha aqui, uma mentirinha ali e as coisas vão sendo levadas. Eu acho que são nas pequenas coisas, não adianta a gente dizer que: 'ah... vamos formar cidadãos... vamos fazer um Brasil melhor...' esses discursos vagos não vão levar a gente a lugar nenhum. Enquanto a gente não trabalhar aqui na base, não mostrar conceitos concretos." (M11)

Mantidas as devidas proporções, como o próprio conceito de cidadania, que sendo típico do mundo moderno, não toma parte da construção teórica de MacIntyre (1984), pode-se dizer que este discurso aponta para os três estágios através dos quais sua concepção das virtudes prossegue: as qualidades necessárias para realizar bens internos às práticas; as qualidades contribuintes para o bem de toda uma vida e a relação destas com a persecução de um bem para os seres humanos. Neste sentido, destaca-se um outro trecho: 
"De repente você pode até sentir vontade (de abandonar), entre sentir vontade e fazer, né, você tem que pesar as coisas: é seu papel (....) não só por obrigação de ser médico, de ser enfermeiro, mas enquanto ser humano." (M7)

Segundo Sellman (2000), quando alguém se engaja na prática da enfermagem compromete-se com o cuidado a um indivíduo ou grupo, assim, para o autor, começar uma tarefa nesta prática profissional é comprometer-se em completá-la ou ao menos conduzi-la até o máximo que as circunstâncias permitam. Requer-se um contínuo compromisso até o ponto no qual é seguro interromper esta prática, sendo que abandoná-la antes disto significa, na melhor das hipóteses, algo censurável e, na pior, causar um dano. Um dos depoimentos que enfoca o 'Pertubando a Rotina' com base nas virtudes explicita esta questão:

"Além disso, nós somos profissionais de saúde: deixar de investir, deixar de proporcionar saúde... isso é muito grave!" (E18)

A despeito das diferentes formulações e ponderações, as recomendações feitas pelos enfermeiros e médicos entrevistados coincidem quanto aos cursos de ação propostos. No cenário 'Perturbando a Rotina', nenhuma resposta sugere abandonar o senhor $\mathrm{C}$, deixando de envidar esforços para continuar a atendê-lo da melhor maneira possível. Para os outros dois, há distintas alternativas traçadas que podem ser observadas nos quadros que seguem. De maneira geral, vale notar que no 'Atendendo Adolescentes', somente uma enfermeira não prescreveria a contracepção, mas todos não contariam nada aos pais, preservando o sigilo profissional. No 'Preservando a Confidencialidade', apenas um médico admite enganar a esposa do senhor $\mathrm{N}$, sem absolutamente estimular que ele the conte a verdade; 9 depoimentos ( 5 enfermeiros e 4 médicos), por outro lado, recomendam solicitar o exame somente após ele contar-lhe sobre sua condição e os demais (1 enfermeiro e 2 médicos) recomendam alternativas intermédias, conforme especificado adiante. 


\section{QUADRO 12: RECOMENDAÇÕES PARA O CENÁRIO 'PRESERVANDO A CONFIDENCIALIDADE' SEGUNDO ENFOQUES}

\begin{tabular}{|c|c|c|c|c|}
\hline $\begin{array}{r}\text { ENFOQUE } \\
\text { CURSOS DE AÇÃO }\end{array}$ & PRINCIPIALISTA & $\begin{array}{c}\text { DAS } \\
\text { VIRTUDES }\end{array}$ & \begin{tabular}{|c|} 
DO \\
CUIDADO
\end{tabular} & $\begin{array}{c}\text { ÉTICA } \\
\text { PROFISSIONAL }\end{array}$ \\
\hline $\begin{array}{l}\text { Solicitar exame } \\
\text { somente depois do } \\
\text { marido contar a } \\
\text { verdade para a mulher }\end{array}$ & $\begin{array}{c}\text { E6, E7, E14 } \\
\text { M12, M13, M16 }\end{array}$ & M11 & $\mathrm{E} 8, \mathrm{E} 10$ & - \\
\hline $\begin{array}{l}\text { Solicitar exame sem } \\
\text { contar a verdade para } \\
\text { a mulher, mas } \\
\text { estimulando que o } \\
\text { marido o faça }\end{array}$ & E13 & -..- & ----- & ----- \\
\hline $\begin{array}{l}\text { Solicitar exame sem } \\
\text { contar a verdade para } \\
\text { a mulher, mas } \\
\text { estimulando que o } \\
\text { marido o faça em face } \\
\text { de um resultado } \\
\text { positivo }\end{array}$ & M8 & -.-- & ----- & ----- \\
\hline $\begin{array}{l}\text { Solicitar exame sem } \\
\text { contar a verdade para } \\
\text { a mulher e sem } \\
\text { estimular que o } \\
\text { marido o faça }\end{array}$ & M6 & ----- & ---- & -..-- \\
\hline $\begin{array}{l}\text { Solicitar exame sem } \\
\text { contar a verdade para } \\
\text { a mulher se o } \\
\text { relacionamento } \\
\text { extraconjugal for um } \\
\text { episódio fortuito, caso } \\
\text { contrário, estimular o } \\
\text { marido a contar a } \\
\text { verdade }\end{array}$ & M15 & - & ----- & ----- \\
\hline
\end{tabular}




\section{QUADRO 13: RECOMENDAÇÕES PARA O CENÁRIO ‘ATENDENDO ADOLESCENTES' SEGUNDO ENFOQUES}

\begin{tabular}{|c|c|c|c|c|}
\hline $\begin{array}{l}\text { ENFOQUE } \\
\text { CURSOS DE } \\
\text { AÇÃO }\end{array}$ & \begin{tabular}{|l|} 
PRINCIPIALISTA \\
\end{tabular} & $\begin{array}{c}\text { DAS } \\
\text { VIRTUDES }\end{array}$ & $\begin{array}{c}\text { DO } \\
\text { CUIDADO }\end{array}$ & $\begin{array}{c}\text { ÉTICA } \\
\text { PROFISSIONAL }\end{array}$ \\
\hline $\begin{array}{l}\text { Prescrever sem } \\
\text { contar para os } \\
\text { pais e sem } \\
\text { estimular que a } \\
\text { adolescente o } \\
\text { faça }\end{array}$ & $\begin{array}{c}\text { E15, E17 } \\
\text { M10, M17, M18 }\end{array}$ & -.-- & ----" & ---- \\
\hline $\begin{array}{l}\text { Prescrever sem } \\
\text { contar para os } \\
\text { pais, mas } \\
\text { estimulando } \\
\text { que a } \\
\text { adolescente o } \\
\text { faça }\end{array}$ & $\begin{array}{c}\text { E12 } \\
\text { M7, M9, M14 }\end{array}$ & "---- & $\begin{array}{l}\text { E16, E18, } \\
\text { E19 } \\
\text { M4 }\end{array}$ & ---- \\
\hline $\begin{array}{l}\text { Não } \\
\text { prescrever, } \\
\text { estimulando } \\
\text { que a } \\
\text { adolescente } \\
\text { fale com os } \\
\text { pais }\end{array}$ & ---- & $\cdots$ & $\cdots$ & E11 \\
\hline
\end{tabular}

Segundo Beauchamp e Childress (2001), a convergência e o consenso sobre princípios entre um grupo de pessoas não é rara ao se avaliar casos e formular políticas, mesmo quando existem diferenças teóricas a dividir o grupo. Isto porque, no equacionamento moral do cotidiano, espontaneamente, as pessoas mesclam as 
explanações dos princípios, regras, direitos, virtudes, paixões, analogias, paradigmas, narrativas e parábolas. O mais geral (princípios, regras, teorias etc.) e o mais particular (juízos de casos, sentimentos, percepções, práticas, parábolas etc.) encontram-se intimamente vinculados no pensamento moral.

Com base nos enfoques escolhidos para referenciar teoricamente a análise desse estudo, os quadros a seguir identificam esta mescla no equacionamento moral dos enfermeiros e médicos entrevistados. Para cada caso hipotético, compôs-se uma matriz, na qual se cruzam os enfoques utilizados na formulação do problema e nos argumentos utilizados na ponderação que baliza o equacionamento: 
QUADRO 14: CENÁRIO 'PERTURBANDO A ROTINA' SEGUNDO ENFOQUES NA FORMULAÇÃO E EQUACIONAMENTO DO PROBLEMA

\begin{tabular}{|c|c|c|c|c|}
\hline $\begin{array}{l}\text { FORMULAÇÃO } \\
\text { ARGUMENTOS }\end{array}$ & $\begin{array}{c}\text { ENFOQUE } \\
\text { PRINCIPIALISTA }\end{array}$ & $\begin{array}{l}\text { ENFOQUE } \\
\text { DAS } \\
\text { VIRTUDES }\end{array}$ & $\begin{array}{c}\text { ENFOQUE } \\
\text { DO } \\
\text { CUIDADO }\end{array}$ & $\begin{array}{l}\text { ENFOQUE DA } \\
\text { ÉTICA } \\
\text { PROFISSIONAL }\end{array}$ \\
\hline $\begin{array}{l}\text { ENFOQUE } \\
\text { PRINCIPIALISTA }\end{array}$ & $\begin{array}{c}\text { E2, E12, E13, E14, } \\
\text { E15, E17 } \\
\text { M4, M6, M10, } \\
\text { M14, M17, M18 }\end{array}$ & $\begin{array}{l}\text { E9, E11, } \\
\text { E18 } \\
\text { M2, M7, } \\
\text { M8, M9 }\end{array}$ & $\begin{array}{c}\text { E3, E6, E8, } \\
\text { E10, E16 } \\
\text { M15 }\end{array}$ & --.-- \\
\hline $\begin{array}{l}\text { ENFOQUE DAS } \\
\text { VIRTUDES }\end{array}$ & --.- & $\begin{array}{l}\text { E9, E11, } \\
\text { E18 } \\
\text { M2, M7, } \\
\text { M8, M9 }\end{array}$ & $\begin{array}{l}\text { E2, E16 } \\
\text { M13 }\end{array}$ & \\
\hline $\begin{array}{l}\text { ENFOQUE DO } \\
\text { CUIDADO }\end{array}$ & $\begin{array}{c}\text { E2 } \\
\text { M18 }\end{array}$ & $\begin{array}{c}\text { E9, E11 } \\
\text { M8 }\end{array}$ & $\begin{array}{c}\text { E1, E3, E5, } \\
\text { E6, E7, E8, } \\
\text { E10, E16, } \\
\text { E19 } \\
\text { M1, M11, } \\
\text { M12, M13, } \\
\text { M15 }\end{array}$ & \\
\hline $\begin{array}{l}\text { ENFOQUE DA } \\
\text { ÉTICA } \\
\text { PROFISSIONAL }\end{array}$ & E14 & M7 & ----- & ----- \\
\hline $\begin{array}{l}\text { ENFOQUE DA } \\
\text { CASUÍSTICA }\end{array}$ & $\begin{array}{l}\mathrm{E} 12, \mathrm{E} 13, \mathrm{E} 14, \mathrm{E} 15 \\
\mathrm{M} 4, \mathrm{M} 6, \mathrm{M} 14, \mathrm{M} 18\end{array}$ & $\begin{array}{c}\text { E9, E11, } \\
\text { E18 } \\
\text { M2, M7, } \\
\text { M8, M9 }\end{array}$ & $\begin{array}{c}\text { E1, E3, E5, } \\
\text { E6, E8, } \\
\text { E10, E16, } \\
\text { E19 } \\
\text { M1, M11, } \\
\text { M12, M13, } \\
\text { M15 }\end{array}$ & ----- \\
\hline
\end{tabular}


QUADRO 15: CENÁRIO 'PRESERVANDO A CONFIDENCIALIDADE' SEGUNDO ENFOQUES NA FORMULAÇÃO E EQUACIONAMENTO DO PROBLEMA

\begin{tabular}{|c|c|c|c|c|}
\hline $\begin{array}{l}\text { FORMULAÇÃO } \\
\text { ARGUMENTOS }\end{array}$ & $\begin{array}{c}\text { ENFOQUE } \\
\text { PRINCIPIALISTA }\end{array}$ & $\begin{array}{c}\text { ENFOQUE } \\
\text { DAS } \\
\text { VIRTUDES }\end{array}$ & $\begin{array}{c}\text { ENFOQUE } \\
\text { DO } \\
\text { CUIDADO }\end{array}$ & $\begin{array}{c}\text { ENFOQUE DA } \\
\text { ÉTICA } \\
\text { PROFISSIONAL }\end{array}$ \\
\hline $\begin{array}{c}\text { ENFOQUE } \\
\text { PRINCIPIALISTA }\end{array}$ & $\begin{array}{c}\text { E6, E7, E13, E14 } \\
\text { M6, M8, M12, } \\
\text { M13, M15, M16 }\end{array}$ & M11 & $\mathrm{E} 8, \mathrm{E} 10$ & ---- \\
\hline $\begin{array}{c}\text { ENFOQUE DAS } \\
\text { VIRTUDES }\end{array}$ & --- & M11 & -.-- & ----- \\
\hline $\begin{array}{c}\text { ENFOQUE DO } \\
\text { CUIDADO }\end{array}$ & $\begin{array}{c}\text { E6, E7, E13, E14 } \\
\text { M8, M13, M15, } \\
\text { M16 }\end{array}$ & M11 & $\mathrm{E} 8, \mathrm{E} 10$ & ....- \\
\hline $\begin{array}{c}\text { ENFOQUE DA } \\
\text { ETICA } \\
\text { PROFISSIONAL }\end{array}$ & -.-- & $-\cdots$ & ---- & -..-- \\
\hline $\begin{array}{l}\text { ENFOQUE DA } \\
\text { CASUÍSTICA }\end{array}$ & $\begin{array}{c}\text { E6, E7, E13, E14 } \\
\text { M6, M8, M12, } \\
\text { M15, M16 }\end{array}$ & M11 & $\mathrm{E} 8$ & ---- \\
\hline
\end{tabular}


QUADRO 16: CENÁRIO 'ATENDENDO ADOLESCENTES' SEGUNDO ENFOQUES NA FORMULAÇÃO E EQUACIONAMENTO DO PROBLEMA

\begin{tabular}{|c|c|c|c|c|}
\hline $\begin{array}{l}\text { FORMULAÇÃO } \\
\text { ARGUMENTOS }\end{array}$ & $\begin{array}{c}\text { ENFOQUE } \\
\text { PRINCIPIALISTA }\end{array}$ & $\begin{array}{l}\text { ENFOQUE } \\
\text { DAS } \\
\text { VIRTUDES }\end{array}$ & $\begin{array}{c}\text { ENFOQUE } \\
\text { DO } \\
\text { CUIDADO }\end{array}$ & $\begin{array}{c}\text { ENFOQUE DA } \\
\text { ÉTICA } \\
\text { PROFISSIONAL }\end{array}$ \\
\hline $\begin{array}{c}\text { ENFOQUE } \\
\text { PRINCIPIALISTA }\end{array}$ & $\begin{array}{c}\text { E12, E15, E17 } \\
\text { M7, M9, M10, } \\
\text { M17, M18, M14 }\end{array}$ & ---- & $\begin{array}{l}\text { E9, E16, } \\
\text { E18, E19 } \\
\text { M4 }\end{array}$ & E11 \\
\hline $\begin{array}{l}\text { ENFOQUE DAS } \\
\text { VIRTUDES }\end{array}$ & E12 & ---- & M4 & ---. \\
\hline $\begin{array}{c}\text { ENFOQUE DO } \\
\text { CUIDADO }\end{array}$ & $\begin{array}{l}\text { E12, E15 } \\
\text { M7, M14 }\end{array}$ & 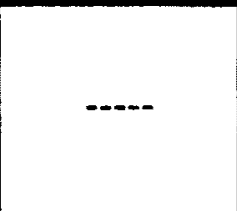 & $\begin{array}{c}\text { E9, E16, } \\
\text { E18, E19 } \\
\text { M4 }\end{array}$ & E11 \\
\hline $\begin{array}{c}\text { ENFOQUE DA } \\
\text { ÉTICA } \\
\text { PROFISSIONAL }\end{array}$ & $\begin{array}{l}\text { E17 } \\
\text { M7 }\end{array}$ & ---- & M4 & E11 \\
\hline $\begin{array}{l}\text { ENFOQUE DA } \\
\text { CASUÍSTICA }\end{array}$ & \begin{tabular}{|c|} 
E17 \\
M7, M9, M10, M14
\end{tabular} & ----י- & $\begin{array}{c}\text { E16, E19 } \\
\text { M4 }\end{array}$ & - \\
\hline
\end{tabular}

Pierce (1997), com base em seus estudos empíricos, afirma que os profissionais de saúde, ao discutirem casos reais, não revelam nenhum modelo de tomada de decisão linear, do tipo passo a passo. Ao invés disso, evidenciam uma abordagem multifacetada, não linear e integrada que se move dos dados e fatos para as alternativas e conseqüências; volta para os dados, valores pessoais, visões de mundo, princípios da bioética e, finalmente, ultima uma escolha e sua justificação.

Em pesquisa etnográfica desenvolvida em uma enfermaria psiquiátrica na Inglaterra, Robertson (1996) encontrou uma integração da ética do cuidado com os 
princípios característicos das tradicionais abordagens da ética em saúde, concluindo que isto pode ser feito com consistência.

A inclusão do enfoque da casuística nos últimos quadros fez-se necessária, pois na argumentação apresentada nos equacionamentos é comum os profissionais apelarem às experiências anteriores e ao raciocínio por paradigma e analogia:

"A gente tem muitos pacientes de saúde mental que estão toda hora aqui (....)" (M9)

"Dificil! É a mesma história do paciente que é portador e não quer que a família saiba, portador do HIV." (E8)

"Eu acho que nesse caso ai, pelo que eu tenho de experiência (....)" (E10)

"Nós tivemos um paciente assim, a cara desse paciente (....) apesar que ele tinha um quadro de psiquiatria (....) a gente desenvolveu (....)" (E18)

“(....) deixa eu ver se eu lembro de algum caso assim para ver o que a gente fez (....)" (E19)

"Seria a mesma coisa se tivesse dado HIV positivo do marido e ele quisesse fazer dela e não... é pior ainda o caso (....)" (M8)

Este raciocínio por paradigma e analogia também ajuda a explicar os cursos de ação propostos no 'Preservando a Confidencialidade', uma vez que estes são similares ao da prática comum para os parceiros discordantes em HIV/AIDS, que pode ter sido utilizado como paradigma pelas indicações dos depoimentos anteriores. 
Ainda expressões como "aí no caso"; "neste caso"; "em relação a esse caso" e "nesse caso aqui" que aparecem nos discursos de diferentes entrevistados, tanto enfermeiros quanto médicos, podem ser compreendidas como uma ponderação das circunstâncias específicas da situação, enquanto conformadoras do caso e, inevitavelmente, modificadoras do juízo ético acerca da questão envolvida, o que é próprio do enfoque da casuística.

Também é possível notar nos quadros anteriores a presença de elementos do enfoque da ética profissional na argumentação, evidenciando uma preocupação de cunho defensivo, ou seja, de estar "respaldado legalmente" por meio das anotações que a equipe registra no prontuário:

"E sempre tá respaldado legalmente: anota no prontuário (....) ou anota em pauta de reunião de equipe (....)" (E14)

“(...) eu acho que precisa ser descrito em prontuário (....) a gente também tem que se respaldar, ter uma retaguarda, fora isso, se acontecesse alguma coisa a gente também taria muito tranqüilo (....)" (M7)

Pesquisa realizada com enfermeiros de Maringá, a fim de explorar a fundamentação dos juízos morais na enfermagem, também aponta para a importância das anotações em prontuário, com preocupações legais referentes a sua interpretação e extravio, embora haja dúvidas quanto ao conteúdo e forma do que deve ser registrado (COELHO 2000).

Neste sentido, cabe registrar que a conduta para parceiros discordantes de HIV/AIDS, que pode ter sido usada como paradigma para as recomendações no cenário 'Preservando a Confidencialidade', está incorporada em pareceres do Conselho Federal de Medicina e de diversos Regionais. Em recente publicação sobre aids e ética médica, o Conselho Regional de Medicina de São Paulo afirma que o médico está "ética e moralmente obrigado a comunicar ao parceiro sexual de um 
indivíduo infectado pelo HIV este fato". Porém, ressalta que isto somente poderá ser feito se "o paciente tiver sido exaustivamente comunicado das prováveis conseqüências para o(a) parceiro(a) do estabelecimento de relações sexuais inseguras ou não protegidas; o médico tiver esclarecido o paciente da natureza das relações sexuais seguras; o médico tiver evidências de que o paciente expõe a risco a(o) parceiro(a); e se o paciente for adequadamente informado pelo médico da intenção de convocar o(a) parceiro(a)" (CREMESP 2001, p. 58).

A utilização, no equacionamento moral, de um paradigma reconhecido pelo enfoque da ética profissional, provavelmente explique porque as preocupações com o "respaldo legal" apareceram apenas nos cenários 'Perturbando a Rotina' e 'Atendendo Adolescentes', não sendo mencionadas no 'Preservando a Confidencialidade'.

Antes de finalizar a apresentação e discussão dos resultados do momento II, vale mencionar que, segundo Gilligan (1998), os dilemas hipotéticos, graças à abstração de sua apresentação, afastam atores morais da história e da psicologia de suas próprias vidas individuais e separam o problema ético das contingências sociais que envolvem sua ocorrência. Ao fazer isto, segundo a autora, esses dilemas são úteis para destilar e refinar os princípios objetivos da justiça e mensurar a lógica formal da igualdade e reciprocidade. Entretanto, a reconstrução do dilema em sua particularidade contextual permite a compreensão da causa e da conseqüência que implica a compaixão e a tolerância observadas, em seus estudos empíricos, na distinção dos juízos morais das mulheres. Somente quando se dá substância aos esqueletos de vida das pessoas hipotéticas é possível considerar a injustiça social que seus problemas morais podem refletir e imaginar o sofrimento individual que sua ocorrência pode significar ou que sua resolução pode engendrar (GILLIGAN 1998)

Dentre os entrevistados neste estudo, a contextualização mostrou-se comum, tanto que muitos respondiam como se estivessem vivendo aquela situação ou se lhes tivesse sido perguntado 'o que você faria' e não 'o que você recomendaria': 
"A gente tem casos assim, de paciente que, às vezes, vem quase todo dia na unidade (....)" (M8)

"O que eu recomendo é o que a equipe adota de conduta" (M9)

"Temos uma aqui assim, Dona (....), não sai da unidade!" (M12)

“(...) eu procuro nesses pacientes (....)” (M13)

“(...) a gente tem uma situação bastante parecida aqui (....)" (E5)

“(....) esse caso faz lembrar vários pacientes que a gente acompanha" (E3)

"Nós estamos vivendo uma situação parecida com essa (....)" (E9)

"O que gente tá acostumado a fazer (....) esse é um caso que a gente tem na área (....)" (E12)

Isto talvez contribua para justificar a mescla dos enfoques principialista e do cuidado que, de forma geral, norteia as resoluções recomendadas nos distintos cenários. 


\section{CONSIDERAÇÕES FINAIS}

A presente pesquisa trata-se de um estudo empírico, qualitativo, de ética descritiva, portanto, de cunho não normativo e desenvolvida com vistas a identificar e caracterizar os problemas éticos que emergem na prática da atenção à saúde $\mathrm{e}$ descrever como os profissionais lidam com tais situações. $O$ cenário escolhido foi o da atenção básica, reorganizada pela estratégia do Programa de Saúde da Família, no Município de São Paulo. Os sujeitos envolvidos foram enfermeiros e médicos.

Os problemas éticos apontados pelos dois grupos de profissionais entrevistados parecem confirmar a idéia de que, na atenção básica, estes são constituídos, de maneira geral, por preocupações do cotidiano da atenção à saúde e não por situações críticas e dramáticas que requerem soluções imediatas, como as enfrentadas no contexto da atenção hospitalar e que são mais exploradas na literatura de bioética.

Também apontam para a responsabilidade ética do gestor em saúde, uma vez que muitos dos problemas éticos listados decorrem da estruturação dos serviços. Evidenciam, assim, que a excelência ética e técnica da prática dos profissionais de saúde passam, obrigatoriamente, pelas políticas públicas de saúde e pelas condições organizacionais da instituição e do sistema de saúde.

As soluções propostas para os cenários hipotéticos apresentados indicam que os enfermeiros e médicos participantes, de maneira geral, têm preocupação em preservar os direitos individuais, mas buscam fazê-lo de forma a proteger ao máximo tanto os vínculos familiares quanto os da equipe com os usuários, o que poderia ser considerado como uma mescla dos enfoques principialista e do cuidado.

Nesta mistura, ainda tem lugar a familiaridade do raciocínio por analogia e paradigma no equacionamento de problemas éticos, que fica patente quando os entrevistados comparam os casos hipotéticos apresentados com situações reais 
semelhantes, vividas por eles próprios ou por colegas. Entretanto, a utilização da casuística como um método de tomada de decisão frente a problemas éticos no cenário da atenção básica, enfrenta limitações e requer a formação de um repertório de casos que incorpore as circunstâncias e situações próprias desta esfera da atenção à saúde e que possa servir para paradigma e analogia.

Chama atenção que o trabalho em saúde, a despeito da fragmentação e tecnicismo de seu processo de produção, ainda é percebido por alguns profissionais como uma prática, no sentido defendido por Alasdair MacIntyre. Como tal, admitem haver um bem interno que os mobiliza e quando este não é atingido, o trabalho na saúde perde seu sentido e fica ofuscado em sua nobreza, equiparando-se a uma ocupação qualquer. Parece abrir-se, desta maneira, um espaço para ética das virtudes no cotidiano e no equacionamento ético dos profissionais de saúde e das equipes de saúde da família.

Outro ponto merecedor de destaque é o fato dos enfermeiros e médicos não conferirem primazia ao enfoque da ética profissional na formulação e equacionamento dos problemas éticos. Este achado contraria expectativas iniciais que tomavam por base o ensino da ética durante a formação destes profissionais, que, muitas vezes, restringe-se à abordagem deontológica contida nos códigos de ética profissional.

Ao se comparar, no momento I, o escopo dos problemas éticos apontados e, no momento II, as recomendações e enfoques no lidar com os cenários hipotéticos, os resultados mostram pequenas diferenças entre os enfermeiros e médicos entrevistados; entretanto, estas não são suficientes para caracterizar os grupos profissionais pela predominância de um dos enfoques ou pela percepção de um determinado tipo de problema ético em especial.

A habilidade para tomar decisões frente aos problemas éticos que emergem das situações cotidianas é essencial para a excelência profissional e da assistência médico-sanitária, pois para que a atenção à saúde mereça o qualificativo de excelente 
deve aliar à exatidão técnica a correta tomada de decisão ética por parte dos profissionais.

O equacionamento ético inclui o exame crítico de situações que envolvem problemas éticos através da análise, ponderação, justificação, escolha e avaliação das razões concorrentes em uma dada circunstância, proporcionando oportunidade para discutir valores e determinar a justificativa moral para o curso de ação escolhido. No equacionamento ético do cotidiano, os profissionais de saúde mesclam as explanações dos principios, regras, direitos, virtudes, paixões, analogias, paradigmas, narrativas e parábolas, correlacionando íntima e mutuamente o mais geral (princípios, regras, teorias) ao mais particular (juizos de casos, sentimentos, percepções, práticas, parábolas etc.). Esta amálgama, além de indicar que uma única perspectiva seria incapaz de abarcar a amplitude e diversidade da dimensão moral da experiência humana, possibilita a convergência na solução de problemas éticos em uma equipe, ainda que persistam diferenças teóricas entre seus integrantes.

O fato dos problemas éticos na atenção básica não poderem ser caracterizados como situações dilemáticas merecedoras do destaque midiático, mas como aspectos éticos que permeiam circunstâncias comuns da prática diária da atenção à saúde não significa que sejam de menor monta ou importância e sim que a atenção básica, quando comparada com a hospitalar, lida com fatos e valores distintos e, por vezes, de maior amplitude e complexidade, ainda que de menor dramaticidade.

Estas peculiaridades dos problemas éticos vividos na atenção básica podem resultar na dificuldade em percebê-los. Tal falha pode por em risco a atenção à saúde prestada nas unidades básicas, resultando no rompimento da relação vincular estabelecida entre os profissionais e os usuários, pois, embora os problemas identificados nesse contexto pareçam triviais frente aos típicos do hospital e sejam sutis a ponto de passarem desapercebidos, podem implicar, quando inadequadamente manejados, em conseqüências desastrosas para os usuários individualmente, para as famílias, para as relações destes com a equipe de saúde e para a comunidade adscrita. 
Atuar na atenção básica reorganizada pela estratégia PSF requer redirecionamento não só da prática clínica, mas também do equacionamento ético, desfocando-os do hospitalocentrismo e da alta especialização que marcam a conformação do sistema de saúde e a formação dos profissionais e que têm levado a bioética, nas últimas três décadas, a centrar-se nas situações limite, em detrimento das situações do cotidiano.

A reorganização da atenção básica pela estratégia do PSF parece reforçar a necessidade da sensibilidade e compromisso éticos, pois sua efetivação não se resume a uma nova configuração da equipe técnico-assistencial ou da unidade básica de saúde. Se a construção do SUS configura um processo de reviravolta ética por exigir dos envolvidos, como os políticos, profissionais, trabalhadores, gestores e usuários, mudanças atitudinais e culturais frente à atenção a saúde, o PSF amplia e aprofunda o trajeto desse giro ético.

A equipe de saúde da família tem de exercer uma nova prática marcada pela humanização, pelo cuidado, pelo exercício da cidadania e alicerçada na compreensão de que as condições de vida definem o processo saúde-doença das famílias, demandando das equipes empenho para sua transformação, no sentido da promoção da saúde.

Desta maneira, a abordagem dos problemas éticos que surgem na atenção básica será incompleta se não incorporar a questão das desigualdades sociais e das políticas públicas em sua discussão, análise e deliberação. Sem desprezar os aspectos relativos à relação intersubjetiva da equipe de saúde com os usuários e família, é necessário reler os distintos enfoques da bioética, conferindo-lhes uma configuração mais estrutural.

Este estudo norteou-se pelos objetivos de identificar e comparar, a partir de depoimentos de enfermeiros e médicos que atuam no Programa Saúde da Família, os problemas éticos por eles vivenciados e os fundamentos que utilizam no equacionamento para a tomada de decisão nestes tipos de situação. Teve também a 
finalidade de explorar a interface da bioética e da atenção básica, com vistas a aproximar a primeira do cotidiano da atenção à saúde. Com base nos resultados apresentados, é possível afirmar que os objetivos e a finalidade propostos foram atingidos. Sem dúvida, ainda há muito para se investigar neste campo, ficando aberta uma linha de pesquisa a ser continuada por estudos ulteriores. 


\section{REFERÊNCIAS BIBLIOGRÁFICAS}

1. Accasto AAM, Alves LC, Pereira EG, Campos CMS, Zoboli ELCP, Fracolli LA. O acolhimento no PSF: validação de concepções através de oficinas de trabalho. São Paulo 2002. [Monografia de Conclusão de Curso de Graduação - Escola de Enfermagem da Universidade de São Paulo]

2. Almeida JLT, Schramm FR. Paradigm shift, metamorphosis of medical ethics, and the rise of bioethics. Cad. Saúde Pública. 1999; 15 (Suppl 1): 1525.

3. Alves Sobrinho EJM, Sousa MF. A tarefa: apagar os sinais vermelhos do PSF. In: Souza MF, organizador. Os sinais vermelhos do PSF. São Paulo: Hucitec; 2002. p. 155-70.

4. Amado-Grunstein R. Differences in ethical decision-making processes among nurses and doctors. Journal of Advanced Nursing. 1992; 17: 129-37.

5. Anais da $8^{a}$ Conferência Nacional de Saúde; 1986 março 17-21; Brasília (DF), Brasil.

6. Anjos MF. Bioética: abrangência e dinamismo. O mundo da saúde. 1997; 21: 4-12.

7. Anjos MF. Bioethics in the perspective of liberation theology. In: Anais do VI Congresso Mundial de Bioética; 2002 out 30 nov 01-03; Brasilia (BR). Brasilia: International Association of Bioethics; 2002. p. 74.

8. Aroskar MA. Community health nurses: their most significant ethical decision-making problems. Nursing Clinics of North America. 1989; 4: 967-75.

9. Arroyo-Gordo MP del, coord. Ética y legislación en enfermería: análisis sobre la responsabilidad profesional. Madrid: McGraw-Hill / Interamericana; 1997. Ética y deontología en enfermeria; p. 71-8.

10. Bardin L. Análise de Conteúdo. Lisboa: Edições 70; 1977.

11. Barros VL. $O$ informar e o consentir enquanto atributos fundamentais para a consolidação dos direitos do paciente São Paulo; 2000. [Dissertação de Mestrado - Faculdade de Saúde Pública da Universidade de São Paulo].

12. Beauchamp TL, Childress JF. Principios de ética biomédica. $4^{\mathrm{a} e d}$. Barcelona: Masson; 1999.

13. Beauchamp TL, Childress JF. Principles of biomedical ethics. $5^{\text {a ed. New }}$ York: Oxford University Press; 2001.

14. Berger MC, Seversen A, Chvatal R. Ethical issues in nursing. Western Journal of Nursing Research. 1991; 13: 514-21.

15. Berlinguer G. Questões de vida: ética, ciência, saúde. Salvador: APCE/São Paulo: HUCITEC/Londrina: CEBES; 1993.

16. Brasil. Ministério da Saúde. Norma Operacional Básica do Sistema Único de Saúde. Diário Oficial da República Federativa do Brasil, Brasília, 6 nov 1996.

17. Brett AS. Inappropriate requests for treatment and tests. In: Sugarman J, organizador. Ethics in primary care. New York: McGraaw-Hill; 2000. p. 311 . 
18. Brody H. Empirical Studies of Ethics in Family Medicine. The Journal of Family Practice. 1983a; 16: 1061-3.

19. Brody H. Empirical Studies of Ethics in Family Medicine. The Journal of Family Practice. 1983b; 16: 1061-3.

20. Brody H. Transparency: informed consent in primary care. Hasting Centers Report. 1989; sep/oct: 5-9.

21. Carman D, Britten N. Confidentiality o medical records: the patient's perspective. British Journal of General Practice. 1995; 45: 485-8.

22. Chiesa AM, Veríssimo MLOR. A educação em saúde na prática do PSF. In: Instituto para o Desenvolvimento da Saúde, Universidade de São Paulo, Ministério da Saúde. Manual de Enfermagem. Brasília: Ministério da Saúde; 2001. p. 34-42.

23. Christie RJ, Hoffmaster B, Bass MJ, McCracken EC. How family physicians approach ethical problems. The Journal of Family Practice. 1983; 16: 1133-8.

24. Clotet J. Bioética: uma ética aplicada em destaque. In: Anais do I Seminário Internacional de Filosofia e Saúde; 1994 nov 16-19; Florianópolis, Brasil. Florianópolis: Sociedade de Estudos em Filosofia e Saúde; 1995. p. 115-29.

25. Coelho LCD. Fundamentação dos juízos morais na enfermagem. Ribeirão Preto: 2000. [Tese de Doutorado - Escola de Enfermagem de Ribeirão Preto da Universidade de São Paulo].

26. Cohn A. A saúde na previdência social e na seguridade social: antigos estigmas e novos desafios. In: Cohn A, Elias PE. Saúde no Brasil: políticas e organização de serviços. $3^{a}$ ed. São Paulo: Cortez/CEDEC; 1999. p. 13-57

27. Connelly J. Emotions, ethics, and decision making in primary care. The Journal of Clinical Ethics. 1998; 9: 225-34.

28. Connelly JE, DalleMura S. Ethical problems in the medical office. JAMA. 1988; 260: 812-5.

29. Connely JE. Refusal of treatment. In: Sugarman J, organizador. Ethics in primary care. New York: McGraaw-Hill; 2000. p. 187-210.

30. Conselho Federal de Enfermagem. Resolução COFEN 240/2000, de 30.08.2000: aprova o Código de Ética dos Profissionais de Enfermagem e dá outras providências. In: Conselho Regional de Enfermagem de São Paulo. Documentos Básicos de Enfermagem. São Paulo: COREN-SP; 2001. p. 277-89.

31. Conselho Federal de Enfermagem. Resolução COFEN 172/1994, de 15.06.1994: normatiza a criação de Comissão de Ética de Enfermagem nas instituições de saúde. In: Conselho Regional de Enfermagem de São Paulo. Documentos Básicos de Enfermagem. São Paulo: COREN-SP; 2001. p. 121-2.

32. Conselho Federal de Medicina. Resolução CFM 1246/88. Código de Ética Médica. Brasília: CFM; 1996.

33. Conselho Federal de Medicina. Resolução CFM 1657/2002, de 11.12.2002: estabelece normas de funcionamento e eleição, competência das Comissões de Ética Médica dos estabelecimentos de saúde e dá outras providências. <URL:http://www.portalmedico.org.br/resolucoes/cfm/2002/1657_2002htm $>[2003$ jun 11]. 
34. Conselho Nacional de Saúde. Resolução $\mathbf{n}^{\mathbf{0}}$ 196, de 10.10.96: dispõe sobre as diretrizes e normas regulamentadoras de pesquisas envolvendo seres humanos.

35. Conselho Regional de Medicina do Estado de São Paulo. Aids e ética médica. São Paulo: CREMESP; 2001.

36. Cortese C, Fedrigotti A. Ética infermeristica: sviluppo morale e professionalità. Milano: Soborna; 1985.

37. Cortina A. Ética aplicada y democracia radical. $2^{\mathrm{a}}$ ed. Madrid: Tecnos; 1997a.

38. Cortina A. Etica de las profesiones. In: Arroyo-Gordo MP del, coord. Ética y legislación en enfermería: análisis sobre la responsabilidad profesional. Madrid: McGraw-Hill/Interamericana; 1997b. p. 51-8.

39. Dayringer R, Paiva EAR, Davidson GW. Ethical decision making by family physicians. The Journal of Family Practice. 1983; 17: 267-72.

40. Diniz D, Guilhem D. O que é bioética. São Paulo: Brasiliense; 2002 [Coleção Primeiros Passos].

41. Doukas DJ, McCullough BL. A preventive ethics approach to counseling patients about clinical futility in the primary care setting. Arch Fam Med. 1996; 5: 589-92.

42. DuBose ER, Hamel R, O'Connell LJ. A Matter of Principles?: Ferment in U.S. Bioethics. Valey Forge: Trinity Press International; 1994.

43. Ducati C, Boemer MR. Comissões de ética de enfermagem em instituições de saúde de Ribeirão Preto. Revista Latino-americana de Enfermagem. 2001; 9: 27-32.

44. Duncan SM. Ethical challenge in community health nursing. Journal of Advanced Nursing. 1992; 17: 1035-41.

45. Durant G. A bioética: natureza, princípios e objetivos. São Paulo: Paulus; 1995.

46. Elias PE. Estrutura e organização da atenção à saúde no Brasil. In: Cohn A, Elias PE. Saúde no Brasil: políticas e organização de serviços. $3^{\mathrm{a}}$ ed. São Paulo: Cortez/CEDEC; 1999. p. 59-133.

47. Fetters MD, Brody H. The epidemiology of bioethics. The Journal of Clinical Ethics. 1999; 10: 107-15.

48. Fortes PAC. Ética e saúde. São Paulo: EPU; 1998.

49. Fortes PAC. $\mathbf{O}$ dilema bioético de selecionar quem deve viver: um estudo de microalocação de recursos escassos em saúde. São Paulo; 2000. [Tese de Livre-Docência - Faculdade de Saúde Pública da Universidade de São Paulo]

50. Fortes PAC, Zoboli ELCP, Spinetti SR. Critérios sociais na seleção de pacientes em serviços de emergência. Rev. Saúde Pública 2001 35: 451-5.

51. Freitas GF. Ocorrências éticas com pessoal de enfermagem de um hospital do município de São Paulo. São Paulo; 2002. [Dissertação de Mestrado - Escola de Enfermagem da Universidade de São Paulo].

52. Furlan M. Etica professionale per infermieri. Padova: Piccin; 1985.

53. Garrafa V. Dimensão da ética em saúde pública. São Paulo: Faculdade de Saúde Pública/USP; 1995.

54. Garrafa V, Porto D. Hard Bioethics: a peripherial perspective of intervention ethics. In: Anais do VI Congresso Mundial de Bioética; 2002 out 30 nov 
01-03; Brasília (BR). Brasília: International Association of Bioethics; 2002. p. 62 .

55. Germano RM. A ética e o ensino de ética na enfermagem do Brasil. São Paulo: Cortez; 1993.

56. Gilligan C. Uma voz diferente: psicologia da diferença entre homens e mulheres da infância à idade adulta. Rio de Janeiro: Rosa dos Tempos; 1982.

57. Gilligan C. In a different voice: psychological theory and women's development. $31^{\mathrm{a}}$ reimpr. Cambridge (Mass): Harvard University Press; 1998.

58. Gillon R. The four principles approach to health care ethics - hegemony? In: Anais do VI Congresso Mundial de Bioética; 2002 out 30 nov 01-03; Brasília (BR). Brasilia: International Association of Bioethics; 2002. p. 61.

59. Gouveia R, Fortes PAC. São Paulo tem o primeiro código de saúde do país. In: Gouveia R., organizador. Saúde pública, suprema lei: a nova legislação para a conquista da saúde. São Paulo: Mandacaru; 2000. p. 37-40.

60. Gracia D. Fundamentos de Bioética. Madrid: Eudema; 1989.

61. Gracia D. Procedimientos de decisión en ética clínica. Madrid: Eudema; 1991.

62. Gracia D. Fundamentación y enseñanza de la bioética. Santa Fé de Bogotá: El Buho; 1998a.

63. Gracia D. Bioética clínica. Santa Fé de Bogotá: El Buho; 1998b.

64. Gramelspacher GP, Howell JD, Young MJ. Perceptions of ethical problems by nurses and doctors. Archives of Internal Medicine. 1986; 146: 577-8.

65. Gremmen I. Visiting nurses' situated ethics: beyond 'care versus justice'. Nursing Ethics. 1999; 6: 515-27.

66. Haddad AM. Ethical problems in home healthcare. JONA. 1992; 22: 46-51.

67. Haimes E. What can the social sciences contribute to the study of ethics? Theoretical, empirical and substantive considerations. Bioethics 2002 16: 89113.

68. Halevy H. Confidentiality. In: Sugarman J, organizador. Ethics in primary care. New York: McGraaw-Hill; 2000. p. 149-60.

69. Hauerwas S. Virtue and Character. In: Reich WT, org. Bioethics Enciclopedya. $2^{\text {a }}$ ed. [CD ROM]. New York: Mac Millan Library; 1995.

70. Hill WY, Fraser I, Cotton P. Patients' voices, rights and responsibilities: on implementing social audit in primary health care. Journal of Business Ethics. 1988; 17: 1481-97.

71. Hoffmaster CB, Stewart MA, Christie RJ. Ethical decision making by family doctors in Canada, Britain and the United States. Social Science Medicine. 1991; 33: 647-53.

72. Holm S. Critical Analyis of Principialism. In: Anais do VI Congresso Mundial de Bioética; 2002 out 30 nov 01-03; Brasília (BR). Brasília: International Association of Bioethics; 2002. p. 61.

73. Horton J, Mendus S. After MacIntyre: critical perspectives on the Work of Alasdair MacIntyre. Notre Dame (EUA): University of Notre Dame Press; 1994.

74. Jacobson JA. Compliance and adherence. In: Sugarman J, organizador. Ethics in primary care. New York: McGraaw-Hill; 2000. p. 39-48. 
75. Jonsen AR, Toulmin S. The abuse of casuistry: a history of moral reasoning. Bekerley: University of California Press; 1988.

76. Jonsen AR, Siegler M, Winslade WJ. Ética clínica. $4^{\mathrm{a}}$. ed. Lisboa: McGrraw-Hill; 1999.

77. Knabe BJ, Stearns JA, Glasser M. Medical students' understanding of ethical issues in the ambulatory setting. Family Medicine. 1994; 26: 442-6.

78. Kushe H, Singer P, Rickard M, Cannold L, van Dyk J. Partial and impartial ethical reasoning in health care professionals. Journal of Medical Ethics. 1997; 23: 226-32.

79. Kushe H, Singer P, Rickard M. Reconciling impartial morality and a feminist ethic of cares. Journal of Value Inquiry. 1998; 32: 451-63.

80. Lalande A. Vocabulário técnico e crítico da filosofia. $3^{\mathrm{a}}$ ed. São Paulo: Martins Fontes; 1999.

81. Lefèvre F, Lefèvre AMC, Teixeira JJV, org. O Discurso do Sujeito Coletivo: uma nova abordagem metodológica na pesquisa qualitativa. Caxias do Sul: EDUCS; 2000.

82. Leopoldo e Silva F. Da ética filosófica à ética em saúde In: Costa SIF, Garrafa V, Oselka G, coord. Iniciação à bioética. Brasília: Conselho Federal de Medicina; 1998. p. 19-36.

83. Loch JA. La confidencialidad en la asistencia a la salud del adolescente: percepciones y comportamientos de un grupo de universitarios de Porto Alegre, RS - Brasil. Porto Alegre: Edipucrs; 2002.

84. Machado MH. Programa de Saúde da Família no Brasil - algumas considerações sobre o perfil de médicos e enfermeiros. In: Souza MF, organizador. Os sinais vermelhos do PSF. São Paulo: Hucitec; 2002. p. 12532.

85. MacIntyre A. After virtue. $2^{\text {nd }}$ ed. Notre Dame: University of Notre Dame Press; 1984.

86. Maeda ST. Gestão da referência e contra-referência na atenção ao ciclo gravídico-puerperal: a realidade do Distrito do Butantã. São Paulo; 2002. [Tese de Doutorado - Escola de Enfermagem da Universidade de São Paulo]

87. Makadon HJ, Gibbons MP. Nurses and Physicians: prospects for collaboration. Annals of Internal Medicine. 1985; 103: 134-6.

88. Maliandi R. Ética: conceptos y problemas. Buenos Aires: Biblos; 1991.

89. Matumoto S. O acolhimento: um estudo sobre seus componentes e sua produção em uma unidade da rede básica de serviços de saúde. Ribeirão Preto; 1998. [Dissertação de Mestrado - Escola de Enfermagem de Ribeirão Preto - Universidade de São Paulo].

90. Matumoto S, Mishima SM, Pinto IC. Saúde Coletiva: um desafio para a enfermagem. Cad. Saúde Pública 2001 17: 233-41.

91. Mayer-Braunack AJ. What makes a problem an ethical problem? An empirical perspective on the nature of ethical problems in general practice. Journal of Medical Ethics. 2001; 27: 98-103.

92. Minayo MCS, organizador. Pesquisa social: teoria, método e criatividade. $6^{\mathrm{a}}$ ed. Petrópolis: Vozes; 1996a.

93. Minayo MCS. $\mathbf{O}$ desafio do conhecimento: pesquisa qualitativa em saúde. $4^{\mathrm{a}}$ ed. São Paulo: HUCITEC/Rio de Janeiro: ABRASCO; $1996 \mathrm{~b}$. 
94. Morrow E. Attitudes of women from vulnerable populations toward physician-assisted death: a qualitative approach. The Journal of Clinical Ethics. 1997; 8: 279-89.

95. Oberle K, Hughes D. Doctors' and nurses' perceptions of ethical problems in end-of-life decisions. Journal of Advanced Nursing. 2001; 33: 707-15.

96. Oddi LF, Cassidy VR, Fisher C. Nurses' sensitive to the ethical aspects of clinical practice. Nursing Ethics. 1995; 2: 197-209.

97. Oliveira AC, Fortes PAC. O direito à informação e a manifestação da autonomia de idosos hospitalizados. Rev. Esc. Enf. USP 1999 33: 59-65.

98. Ortiz-Ibarz J. La hora de la ética empresarial. Madrid: McGraw-Hill; 1995.

99. Ozar DT. Profession and professional ethics. In: Reich WT, org. Bioethics Enciclopedya. $2^{a}$ ed. [CD ROM]. New York: Mac Millan Library; 1995.

100. Pellegrino ED, Hart RJ, Henderson SR, Loeb SE, Edwards G. Relevance an utility of courses in medical ethics: a survey of physicians' perceptions. JAMA. 1985; 253: 49-53.

101. Pessini L, Barchifontaine CP. Bioética: do principialismo à busca de uma perspectiva latino-americana. In: Costa SIF, Garrafa V, Oselka G, coord. Iniciação à bioética. Brasilia: Conselho Federal de Medicina; 1998. p. 81-98.

102. Pessini L, Barchifontaine CP. Problemas atuais de Bioética. $5^{\mathrm{a}}$ ed. São Paulo: Loyola; 2000.

103. Pessini L, Barchifontaine CP. Problemas atuais de Bioética. $6^{a}$ ed. São Paulo: Loyola; 2002.

104. Pfeifer MP, Sidorov JE, Smith AC, Boero JF, Evans AT, Settle MB. The discussion of end-of-life medical care bu primary care patients and physicians. Journal of General Internal Medicine. 1994; 9: 82-8.

105. Pierce SF. A model for conceptualizing the moral dynamic in health care. Nursing Ethics. 1997; 4: 483-95.

106. Pinho RR, Nascimento AM. Instituições de direito público e privado. Introdução ao estudo de direito. Noções de ética profissional. $20^{2}$ ed. São Paulo: Atlas; 1997.

107. Potter VR. Bioethics: bridge to the future. Englewood Cliffs: Prentice-Hall; 1971.

108. Potter VR. Vídeo conferência. O mundo da saúde. 1998; 22: 370-374. [apresentado no IV Congresso Mundial de Bioética; 1998 Nov 04-07; Tóquio].

109. Prescott PA, Hart RJ, Bowen AS. Physician-nurse relationships. Annals of Internal Medicine. 1985; 103: 127-33.

110. Reich WT, org. Bioethics Enciclopedya. $2^{a}$ ed. [CD ROM]. New York: Mac Millan Library; 1995a. Introduction.

111. Reich WT, org. Bioethics Enciclopedya. $2^{\text {a }}$ ed. [CD ROM]. New York: Mac Millan Library; 1995b. History of the notion of care.

112. Richter J, Eisemann MR. Attitudinal patterns determining decision-making in the treatment of the elderly: a comparison between physicians and nurses in Germany and Sweeden. Intensive Care Med. 2000; 26: 1326-33.

113. Rickard $M$, Kushe H, Singer P. Caring and justice: a study of two approaches to health care ethics. Nursing Ethics. 1996; 3: 212-23.

114. Rizzotto MLF. História da enfermagem e sua relação com a saúde pública. Goiânia: AD; 1999. 
115. Robertson DW. Ethical theory, ethnography, and differences between doctors and nurses in approaches to patient care. Journal of Medical Ethics. 1996; 22: 292-9.

116. Robillard HM, High DM, Sebastian JG, Pisaneschi JI, Perritt LJ, Mahler DM. Ethical issues in primary health care: a survey of practioners' perceptions. Journal of Community Health. 1989; 14: 9-17.

117. Ross LJ, Lantos J. Treating Minors. In: Sugarman J, organizador. Ethics in primary care. New York: McGraaw-Hill; 2000. p. 177-85.

118. Sacardo DP. Expectativa de privacidade segundo pessoas hospitalizadas e não hospitalizadas: um estudo bioético. São Paulo; 2001. [Dissertação de Mestrado - Faculdade de Saúde Pública da Universidade de São Paulo]

119. Sánchez-González M. La investigación bioética: tipos, funciones y relaciones mutuas. Cuadernos del Programa Regional de Bioética 1998 Ago; 6: 57 76.

120. São Paulo. Lei $\mathrm{n}^{\circ} 10.241$, de 17 de março de 1999. Dispõe sobre os direitos dos usuários dos serviços de saúde e das ações de saúde no Estado e dá outras providências. In: Gouveia R., organizador. Saúde pública, suprema lei: a nova legislação para a conquista da saúde. São Paulo: Mandacaru; 2000. p. $177-82$.

121. Schramm FR. A autonomia difícil. Bioética. 1998; 6: 27-37.

122. Searight HR, Barbarash RA. Informed Consent: clinical and legal issues in family practice. Family Medicine. 1994; 26: 244-9.

123. Secretaria de Saúde da Prefeitura Municipal de São Paulo. Implantando o PSF no município de São Paulo: balanço de um ano. São Paulo:2002.

124. Sellman D. Alasdair MacIntyre and the professional practice of nursing. Nursing Philosophy. 2000; 1:26-33.

125. Sietsema MR. Ethics and administrative decision making. JONA. 1987; 17: 28-32.

126. Silva JA, Dalmaso ASW. Agente Comunitário de Saúde: o ser, o saber, o fazer. Rio de Janeiro: Fiocruz; 2002.

127. Souza MF, organizador. Os sinais vermelhos do PSF. São Paulo: Hucitec; 2002. Capital humano no PSF: revendo o passado e imaginando o futuro; $p$. $105-14$.

128. Spinsanti S. Ética biomédica. São Paulo: Paulinas; 1990.

129. Sugarman J, organizador. Ethics in primary care. New York: McGraawHill; 2000. Preface; p. xiii-xvi.

130. Sulmasy DP, Sugarman J. The many methods of medical ethics. In: Sugarman J, Sulmasy DP, organizadores. Methods in medical ethics. Washington DC: Georgetown University Press; 2001. p. 3-18.

131. Sumner W, Boyle J. Philosophical Perspectives on Bioethics. Toronto: University of Toronto Press; 1996.

132. Thomas J, Wainwright P. Community nurses and health promotion: ethical and political perspectives. Nursing Ethics. 1996; 3: 97-107.

133. Tong R. The ethics of care: a feminist virtue ethics of care for healthcare practioners. Journal of Medicine and Philosophy. 1998; 23: 131-52.

134. Triviños ANS. Introdução à pesquisa em ciências sociais: a pesquisa qualitativa em educação. São Paulo: Atlas; 1995. 
135. Udén G, Norberg A, Lindseth A, Marhaug V. Ethical reasoning in nurses' and physicians' stories about care episodes. Journal of Advanced Nursing. 1992; 17: 1028-34.

136. Van Der Arend AJG, Remmers-Van Der Hurk HM. Moral problems among dutch nurses: a survey. Nursing Ethics. 1999; 6: 468-82.

137. Vergnières S. Ética e política em Aristóteles: physis, ethos, nomos. São Paulo: Paulus; 1998.

138. Viens DC. Moral dilemmas experienced by nurse practitioners. Nurse Practitioner Forum. 1994; 5: 209-14.

139. Wagner N, Ronen I. Ethical dilemmas experienced by hospital and community nurses: an Israeli survey. Nursing Ethics. 1996; 3: 294-304.

140. Wainwright P. Critical response to Sellman's paper. Nursing Philosophy. 2000; 1: 34-5.

141. Wellard S. The nature of dilemmas in dialysis nurse practice. Journal of Advanced Nursing. 1992; 17: 951-8.

142. Wolf SM. Feminism and Bioethics: Beyond the reproduction. New York: Oxford University Press; 1996.

143. Zoboli ELCP. Ética e administração hospitalar. São Paulo: Loyola/Editora do Centro Universitário São Camilo; 2002.

144. Zoboli ELCP, Martins CL, Fortes PAC. O programa saúde da família na busca da humanização e da ética na atenção à saúde. In: Instituto para o Desenvolvimento da Saúde, Universidade de São Paulo, Ministério da Saúde. Manual de Enfermagem. Brasília: Ministério da Saúde; 2001. p. 47-50.

145. Zoboli ELCP, Massarollo MCKB. Bioética e consentimento: uma reflexão para a prática da enfermagem. O mundo da saúde. 2002; 26: 65-70. 


\section{ANEXO 1 \\ TERMO DE RESPONSABILIDADE DA PESQUISADORA}

Prezado (a) Colega,

Estamos realizando, pela Faculdade de Saúde Pública da Universidade de São Paulo, pesquisa de doutorado para reconhecer problemas éticos vividos em unidades básicas de saúde e para a qual pedimos sua participação em uma entrevista a ser gravada e que será dividida em duas partes. No primeiro momento, você será solicitado (a) narrar uma situação de sua prática profissional na qual tenha se deparado com um problema ético. Em seguida, será pedido que você sugira solução para um caso apresentado pela pesquisadora.

Não há necessidade que você se identifique, pois queremos manter seu anonimato. Também asseguramos o anonimato dos serviços e das pessoas envolvidas nos casos relatados, pois, além de não ser necessário que você os nomeie, na transcrição das fitas serão excluidos nomes ou qualquer particularidade eventualmente citadas e que, porventura, possibilitem identificações.

Os dados obtidos serão guardados em segredo profissional e somente serão utilizados pela pesquisadora para os propósitos da pesquisa.

Essa pesquisa conta com o aval da instituição, mas você é totalmente livre para se recusar a participar, sem riscos de prejuizo porque sua recusa ou aceitação será mantida sob sigilo.

Caso você assim o queira, a entrevista poderá ser realizada fora da unidade de saúde. Se quiser quaisquer esclarecimentos sobre a pesquisa, pode contatar a pesquisadora pelo telefone 3066-7652.

Agradecemos sua cooperação,

Elma Lourdes Campos Pavone Zoboli Doutoranda FSP/USP
Paulo Antonio de Carvalho Fortes

Professor Associado FSP/USP

Orientador 


\title{
ANEXO 2 \\ SOLICITAÇÃO DE CONSENTIMENTO INSTITUCIONAL PARA REALIZAÇÃO DA PESQUISA
}

\author{
Prezado Diretor (a)
}

A presente pesquisa de doutorado realizada pela Faculdade de Saúde Pública da Universidade de São Paulo tem como objetivo principal identificar os fundamentos éticos envolvidos na tomada de decisão de enfermeiros e médicos que atuam em unidades básicas de saúde, com vistas a poder colaborar para a melhoria da atenção prestada na rede. Para o seu desenvolvimento pretende-se entrevistar os profissionais mencionados, solicitando-lhes que narrem uma situação de sua prática profissional na qual tenha se deparado com um problema ético e que sugiram solução para um caso apresentado pela pesquisadora. Os profissionais, após esclarecimentos sobre a pesquisa, serão livres para consentir participar, independentemente do aval institucional.

Manteremos o anonimato dos profissionais entrevistados e dos serviços e das pessoas envolvidas nos casos relatados, pois, além de não ser necessário a nomeação destes, na transcrição das fitas serão excluídos nomes ou qualquer particularidade eventualmente citada e que, porventura, possibilitem identificações.

Os dados obtidos serão guardados em segredo profissional e somente serão utilizados pela pesquisadora para os propósitos desta pesquisa.

As entrevistas serão agendadas e realizadas de forma a não perturbar as atividades dos profissionais e da unidade de saúde.

Se quiser quaisquer esclarecimentos sobre a pesquisa, pode contatar a pesquisadora pelo telefone 3066-7652.

Agradecemos sua cooperação,

Elma Lourdes Campos Pavone Zoboli

Doutoranda FSP/USP
Paulo Antonio de Carvalho Fortes

Professor Associado FSP/USP - Orientador

Consinto com a realização da pesquisa:

Instituição:

Responsável:

Data: 